\title{
FISCALIZAÇÃO PATRIMONIAL DA ADMINISTRAÇÃO PÚBLICA
}

\author{
Dissertação de Mestrado \\ Professor Orientador: José Maurício Conti
}

Faculdade de Direito da Universidade de São Paulo

São Paulo

2013 


\section{Fiscalização Patrimonial da Administração Pública}

\section{DEDICATÓRIA:}

Dedico este trabalho a todas as pessoas que de alguma forma participaram dos momentos de minha vida durante sua confecção.

Entretanto, algumas participaram em maior proporção. Assim, merecem o crédito (principalmente pela paciência em me aturar).

Aos pais, Lurdes e Luiz Fernando, porque sem eles eu não estaria aqui escrevendo. Devo-lhes o que sou. À esposa, Andrea Chiaratti, e aos filhos Marcela Luísa e João Pedro, porque nada mais importa se não for com e para eles. Ao restante da família e aos amigos, porque se a vida for feita de círculos concêntricos, o núcleo existe melhor com aqueles que estão mais próximos e que fazem da coincidência a prazerosa convivência. 


\section{Fiscalização Patrimonial da Administração Pública}

\section{AGRADECIMENTOS:}

Por primeiro e sempre, Àquele que nos deu o dom da vida.

Escrever não é tarefa fácil. Exige tempo e dedicação, ainda mais quando não há liberdade, mas sim uma série de itens restritos a serem seguidos. Mesmo assim, há quem nos incentive a fazê-lo e quem nos tolere enquanto fazemos.

Várias pessoas participaram do processo, algumas na origem fornecendo a ideia de iniciar o trabalho e outras no correr da luta, ouvindo os reclamos e compartilhando as idiossincrasias.

Assim, agradeço, inicialmente, ao meu amigo Eduardo Roberto Alcântara Del Campo, Promotor de Justiça e um tanto ‘culpado' pelo que está aqui, posto que foi o autor do 'empurrão' para que eu fosse fazer a prova do mestrado na USP, enquanto finalizava seu próprio mestrado e compartilhávamos a Secretaria, junto à diretoria da Associação Paulista do Ministério Público.

Agradeço, ainda, ao meu orientador Professor Doutor José Maurício Conti, Juiz de Direito e uma das mais brilhantes mentes do Direito Financeiro do Brasil, porque aceitou a incumbência, mesmo sabendo que nenhuma linha da dissertação havia sido escrita, quando eu sei que sua metodologia pede sempre o trabalho em estado avançado, o que deve ter lhe custado algumas horas de sono. Suas orientações, em mais de uma oportunidade, readequaram e realinharam meu percurso.

Assim, também cabe agradecer aos Doutores Edmir Netto de Araújo e Floriano de Azevedo Marques Neto, pelas valiosas indicações quando do ato formal da qualificação do trabalho na Faculdade de Direito do Largo do São Francisco e que muito enriqueceram o tema desenvolvido. E uma palavra à amiga Dulce Sícoli pelo auxílio na tradução para o inglês. 
Não posso deixar de mencionar o Dr. Cláudio Ferraz de Alvarenga, ex Procurador Geral de Justiça bandeirante (e que, além de me incentivar nos idos de 1988 a prestar concurso para o Ministério Público ainda me deu posse) e ex Presidente e Corregedor do Tribunal de Contas do Estado de São Paulo, que mui gentilmente me recebeu em seu gabinete no TCE, abrindo as portas da Instituição para as pesquisas necessárias, considerado o tema da dissertação.

Uma especial referência aos funcionários da biblioteca do Ministério Público, Vagner Roberto Mirando Postigo e a Sydilene Lopes da Silva, pelas buscas sempre diligentes das obras e textos por mim solicitados.

Ainda, uma nota de retribuição aos colegas - alguns breves, outros nem tanto - que comigo compartilharam os créditos na Faculdade, posto que sempre tinham algo a acrescentar com suas palestras e aulas magníficas, além das experiências pessoais, sempre engrandecendo o exercício profissional de um humilde operador do direito. Retribuição esta que se estende aos professores que muito transmitiram de seus conhecimentos, tornando sempre dinâmica a realização dos debates travados em sala de aula.

Finalmente, agradeço à minha família, em especial esposa e filhos, pela paciência em aturar momentos difíceis nos quais o excesso de responsabilidade mitigava o carinho em prol da racionalidade, transformando minha até então constante presença junto a eles (várias delas sentado ao piano), em isolamento e transformando o sorriso em uma face carrancuda.

Peço desculpas se esqueci de mencionar alguém, e admito desde logo a injustiça, mas, certamente, mesmo faltando no papel, existe a certeza de que este alguém está presente nos meus melhores pensamentos. 


\section{INTRODUČ̃̃O.}

A história do homem e de sua vida em sociedade nos mostra que diversas e distintas foram as etapas vivenciadas na vida coletiva e nas inter-relações entre os membros de uma determinada comunidade.

Resultaram, por via de consequência, estudos variados sobre a evolução acontecida e a forma de partilhar ou não os bens necessários à sobrevivência de um grupo social formado, com abordagens que dizem respeito ao que é considerado como pertencente a todos e o significado do 'pertencer' (ser útil, servir a, etc).

Assim, chegados os dias atuais, devemos assumir que a escassez de recursos e o incessante debate sobre como alocá-los de forma otimizada implica no reconhecimento da necessidade da existência de um sistema adequado de controle por parte da sociedade, frente a quem detém o poder de decidir sobre seus destinos.

Nesta esteira, e afirmando que o Estado de Direito é criação do homem moderno visando oferecer à coletividade condições necessárias à realização do bem comum, da ordem social e da paz, foi aquele ente dotado de instrumental que favorece o equilíbrio de forças em um sistema de freios e contrapesos.

Dentro da estrutura construída para as dicotomias Estado/Sociedade, Administrando/Administrado, um sistema político avançado exige para a obtenção da harmonia social a existência de uma Constituição a indicar os parâmetros comportamentais da sociedade.

No Brasil, após histórico de períodos com concentração de poder e evolução no sentido de maior participação social nos centros de decisões, a promulgação da Constituição Federal em 1988 permitiu efetivamente uma mudança de paradigmas nos rumos da nação.

Estabeleceu a Carta Magna diversos parâmetros permissivos de controle social sobre as decisões adotadas na administração pública. Na medida em que se faz naturalmente inviável que as decisões sejam tomadas por todos os membros da sociedade, 
o sistema deve acontecer de modo a ensejar que aqueles que detém a representatividade do corpo social possam e devam prestar contas de seus atos.

Decorre daí a necessidade de um sistema de controle dos atos da administração pública e a Constituição Federal assim prevê, com tal escopo, a fiscalização contábil, financeira, orçamentária, operacional e patrimonial da União e demais entidades da administração direta e indireta.

Estabelece como parâmetros: legalidade, legitimidade, economicidade, aplicação de subvenções e renúncia de receitas, referindo a dualidade controle externo/interno.

Indica que prestará contas qualquer pessoa física ou jurídica, pública ou privada, que utilize, arrecade, guarde, gerencie ou administre dinheiros, bens e valores públicos ou pelos quais a União responda, ou que, em nome dela assuma obrigações de natureza pecuniária.

Portanto, se observa que o legislador constitucional procurou ser o mais abrangente possível no que tange à fixação da transparência exigida ao administrador público responsável pelo gerenciamento do patrimônio que em última instância pertence à sociedade, sendo que a busca pela otimização de resultados nas decisões implica em conhecimento das rotinas para sugestões de melhoras e que a indevida atitude diante da responsabilidade a que se propõe enseja punições, muitas delas de gravidade intensa.

Neste sentido, tarefa árdua proposta como desafio no presente trabalho é a discussão sobre conceitos relativos ao 'patrimônio público' inseridos no mencionado comando normativo bem como o alcance de sua fiscalização.

Destarte, observa-se que distintas são as facetas encontradas no tema da fiscalização patrimonial da administração pública e cujo debate pode enriquecer a abordagem na dinâmica do relacionamento dos responsáveis por administrar aquele patrimônio e o resultado pretendido na busca de uma sociedade melhor e mais justa, que, afinal, é em última instância o propósito da existência da estrutura do Poder junto ao Estado. 


\section{RESUMO:}

Pretende-se com o presente trabalho discutir o alcance da expressão ‘patrimônio público' e o espectro de atuação dos órgãos responsáveis pela sua fiscalização, sempre sob a perspectiva de que a sociedade é a destinatária final das benesses que dele derivam.

Observa-se que a expressão ‘patrimônio público’ não detém unanimidade na doutrina e por vezes é utilizada como sinônimo de 'bem público' enquanto que, em outras oportunidades, com característica distinta. Deriva daí a necessidade de fixação dos limites de seu significado para que se possa traçar também o âmbito de atuação dos órgãos responsáveis por sua fiscalização.

Dispõe a Constituição Federal em seu art. 70 que "A fiscalização contábil, financeira, orçamentária, operacional e patrimonial da União e das entidades da administração direta e indireta, quanto à legalidade, legitimidade, economicidade, aplicação das subvenções e renúncia de receitas, será exercida pelo Congresso Nacional, mediante controle externo, e pelo sistema de controle interno de cada Poder".

Ainda no parágrafo único, com redação dada pela Emenda Constitucional n ${ }^{\circ}$ 19 de 1998: "Prestará contas qualquer pessoa física ou jurídica, pública ou privada, que utilize, arrecade, guarde, gerencie ou administre dinheiros, bens e valores públicos ou pelos quais a União responda, ou que, em nome desta, assuma obrigações de natureza pecuniária”.

A questão que se coloca é saber efetivamente o que é o 'patrimônio público' e como se opera sua fiscalização, com as respectivas orientações para sua gestão e sanções para o caso de descumprimento das normas.

Assim, é necessário que se realize previamente uma apresentação sobre a estrutura do Estado e da administração pública brasileira e ainda como a Constituição Federal as delineou, para que se estabeleça como os órgãos de controle estão inseridos nessa realidade, bem como quais os limites para que possam atuar, tanto no contexto geral da administração como no específico do patrimônio público. 
Portanto, o trabalho foi realizado na busca de elementos essenciais para o entendimento de como funciona a administração pública e da forma que acontece sua fiscalização, em especial no tema patrimonial. 


\begin{abstract}
:
The purpose of this paper is to discuss the significance of the term 'public property' and the range of activities in charge of the entities responsible for its supervision, always bearing in mind that Society is the final beneficiary of any benefits or profits arising thereof.
\end{abstract}

It is to be observed that the expression 'public property' holds no unanimity in doctrine and sometimes is used as a synonym for 'public good' whilst, at other times, with a different trait. It is imperative, therefore, to establish the limits of its meaning, so that we can also trace the scope of activity of the organs responsible for its supervision.

The Brazilian Constitution states in its article 70 that "The fiscalization of the Union accounting, finances, budget, operations and patrimony, as well as of the entities of the direct and indirect administration, in regards to the legality, legitimacy, economy, implementation of grants and waiver of revenue, shall be exercised by the National Congress through external control, as well as by the internal control system of each Power."

Its single paragraph, amended by Constitutional Amendment $\mathrm{n}^{\circ} 19$ of 1998, complements: "Any person or entity, public or private, which uses, collects, stores, manages or administers public funds, properties and values, or any others for which the Union is responsible, or on its behalf assumes obligations of a pecuniary nature, shall be obliged to render accounts of its acts."

The question that arises is to know the exact definition of 'public property' and how its supervision operates, with the respective guide for its management as well as the sanctions applied in case of breach of the law.

Hence, it is necessary to conduct a prior presentation on the structure of the Brazilian government and the public administration, as well as describe how the Federal Constitution outlined them, in order to establish how the controlling entities are inserted in this reality, and under which limits they can act, both in the overall administration context and, particularly, regarding the public patrimony. 
Therefore, the work was focused in the search of the essential elements for the thorough understanding of the operation of the Brazilian Government and how its supervision is executed, particularly in the patrimonial theme. 
SUMÁRIO

Título: Fiscalização Patrimonial da Administração Pública

CAPÍTULO 1 - O ESTADO E OS PODERES. MODELO BRASILEIRO........................ 17

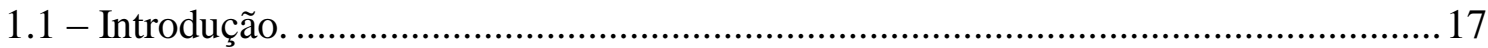

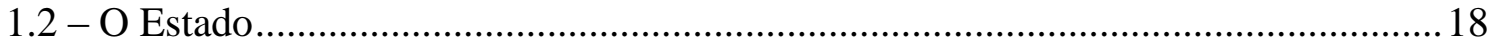

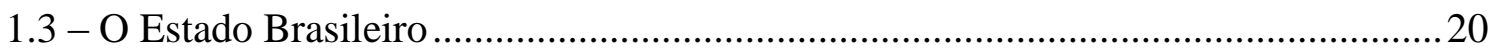

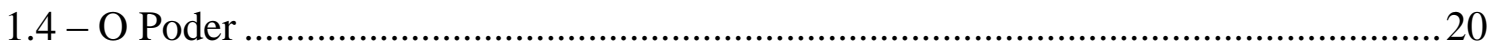

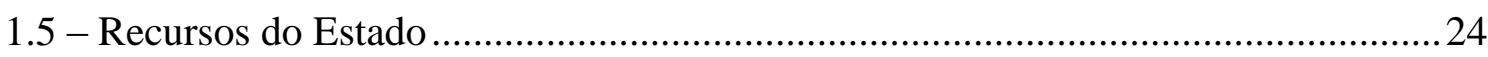

CAPÍTULO 2 - A ADMINISTRAÇÃO PÚBLICA. ........................................................ 27

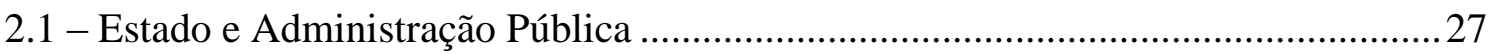

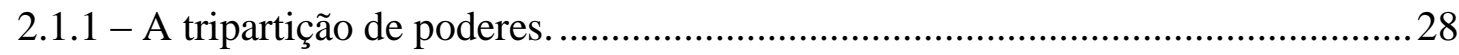

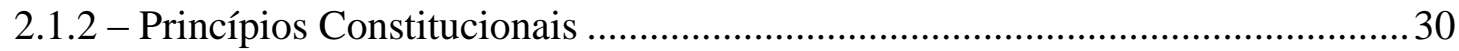

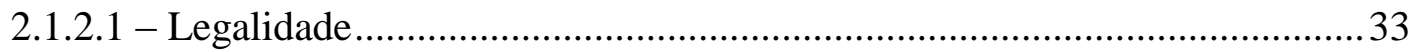

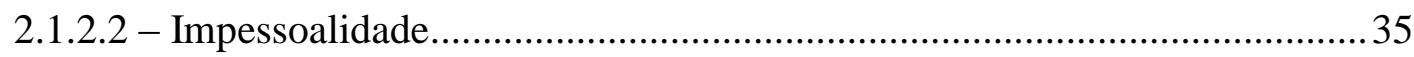

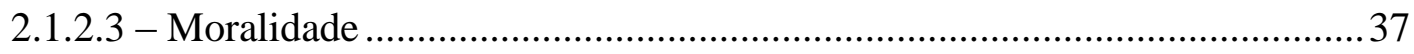

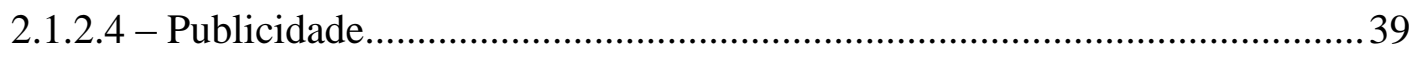

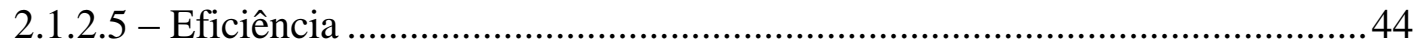

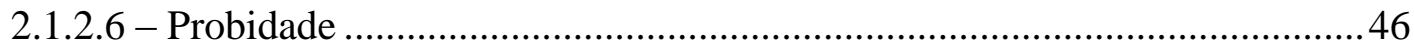

2.1.2.6.1 - A Lei de Improbidade Administrativa ...............................................50

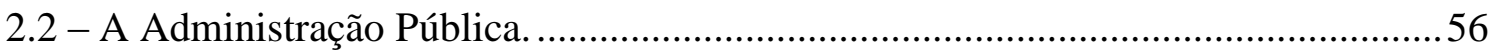

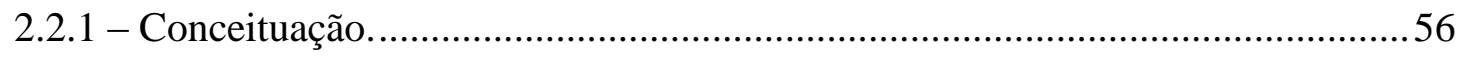

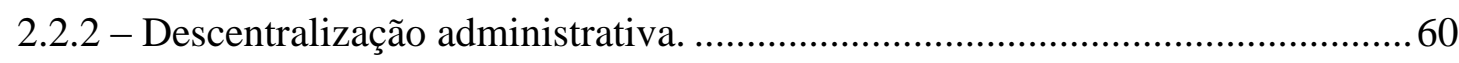

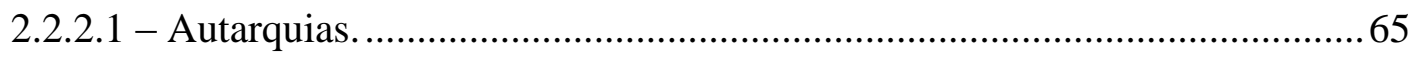

2.2.2.2 - Fundações Públicas e de Apoio. ….......................................................... 70

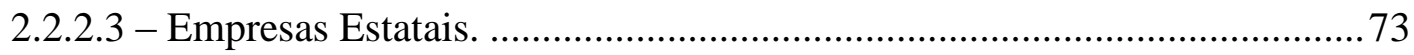

2.2.2.3.1 - Empresas Públicas. ........................................................................... 74

2.2.2.3.2 - Sociedades de Economia Mista. ....................................................... 75

2.2.3 - A Comissão Interministerial de Governança Corporativa e de Administração

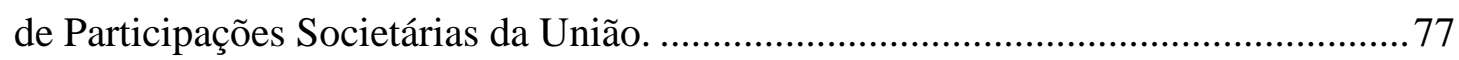

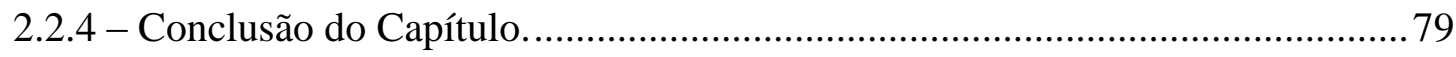


CAPÍTULO 3 - CONTROLE E FISCALIZAÇÃO ...................................................... 81

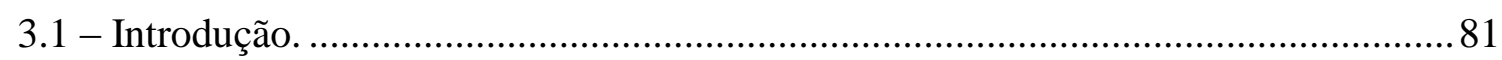

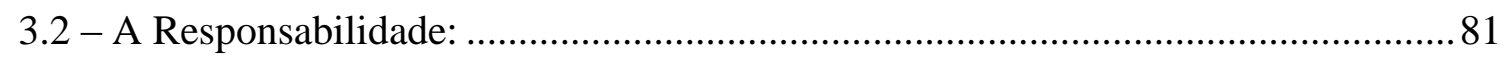

3.2.1 - Responsabilidade Civil e Responsabilidade por Princípios ............................ 84

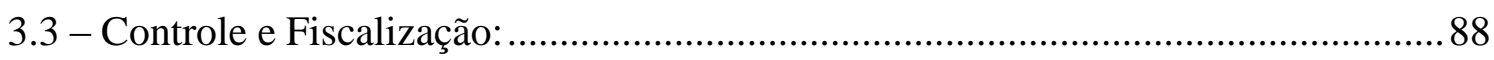

3.3.1 - A exigência de Prestação de Contas .................................................................. 90

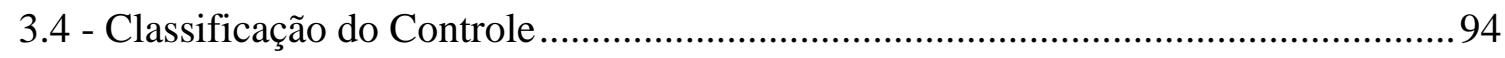

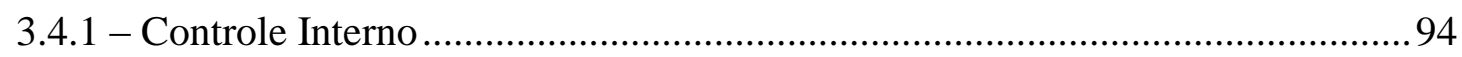

3.4.1.1 - Momento prévio, concomitante e subsequente......................................96

3.4.1.2 - Objetivos, estruturação e conteúdo do controle interno. ..........................97

3.4.1.3 - Controladoria Geral da União (CGU) e Advocacia Geral da União (AGU). 100

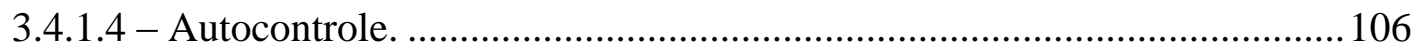

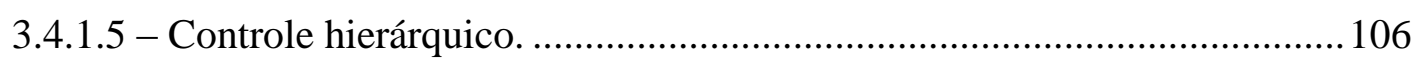

3.4.1.6 - Conclusões sobre o Controle Interno.................................................... 107

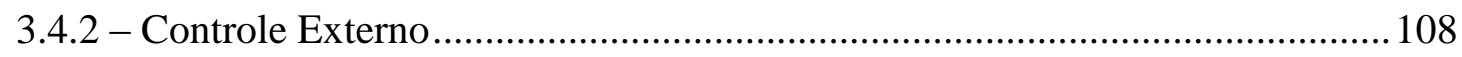

3.4.2.1 - Controle Externo direto exercido pelo Poder Executivo. ......................... 110

3.4.2.1.1 - Crimes de Responsabilidade.......................................................... 112

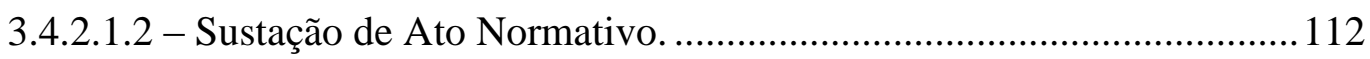

3.4.2.1.3 - Informações prestadas diretamente................................................ 113

3.4.2.1.4 - Julgamento de Contas do Chefe do Poder Executivo e do Governo.

3.4.2.1.5 - Disponibilização de Contas. ........................................................ 114

3.4.2.1.6 - Comissões Parlamentares. ................................................................ 115

3.4.2.1.7 - Sustação de execução contratual e relação com o Tribunal de Contas. 115

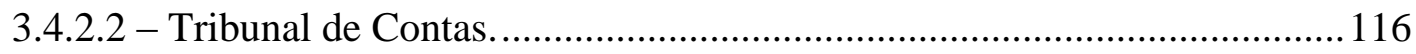

3.4.2.3 - Lei de Diretrizes Orçamentárias (17 de agosto de 2012)........................117

3.4.2.4 - O Controle Externo pelo Poder Judiciário................................................ 127

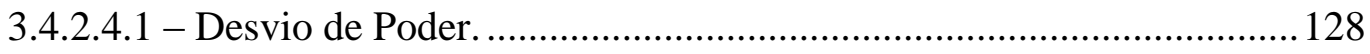

3.4.2.4.2 - Mitigações ao controle jurisdicional............................................ 130

3.4.2.4.3 - Instrumentos judiciais de controle............................................... 132

3.4.2.4.3.1 - Ação Direta de inconstitucionalidade e Representação

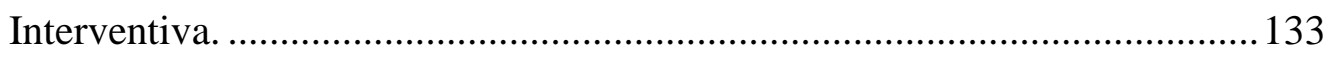




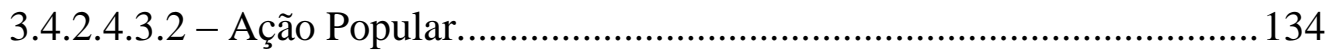

3.4.2.4.3.3 - Ação Civil Pública ................................................................... 134

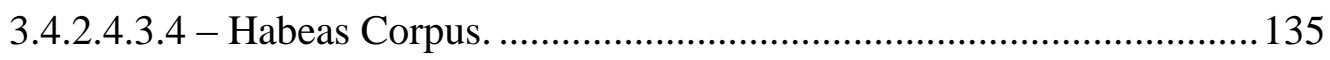

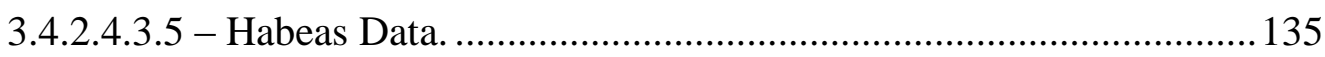

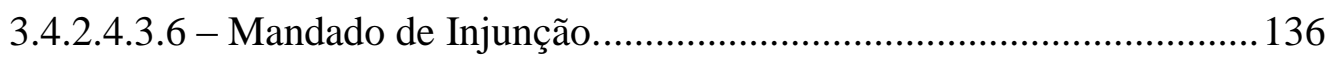

3.4.2.4.3.7 - Mandado de Segurança.......................................................... 136

3.4.2.5 - Conclusões sobre o Controle Externo.................................................... 137

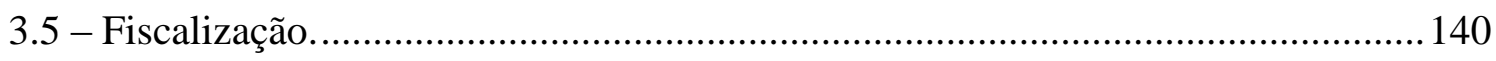

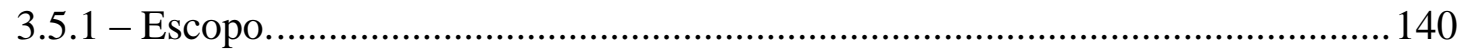

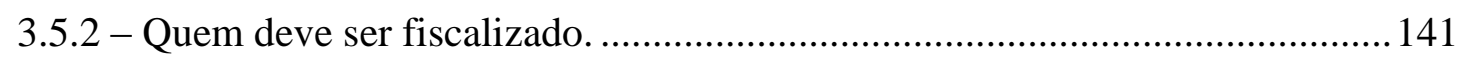

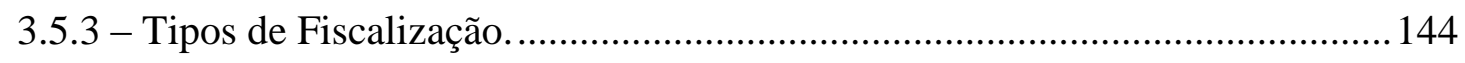

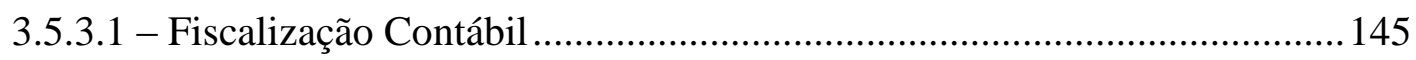

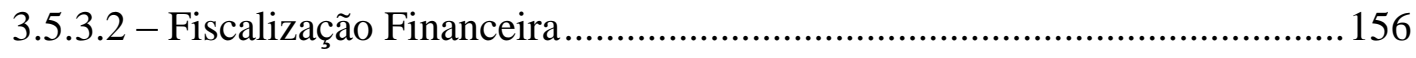

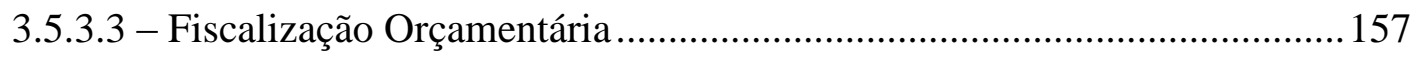

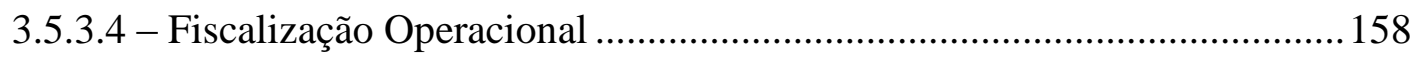

3.5.3.5 - Fiscalização Patrimonial .................................................................. 159

3.5.3.5.1 - Os procedimentos de Auditoria na Fiscalização Patrimonial .......... 165

3.6 - O artigo 70 da Constituição Federal. ................................................................. 177

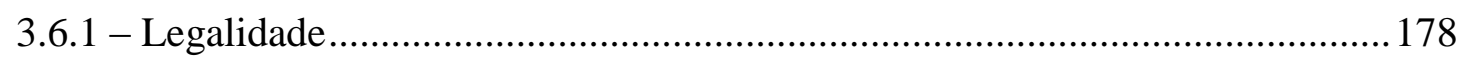

3.6.1.1 - Controle de Constitucionalidade.......................................................... 179

3.6.1.1.1 - Controle de Constitucionalidade e o Tribunal de Contas. ............... 181

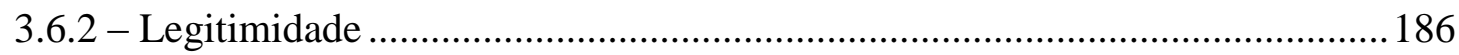

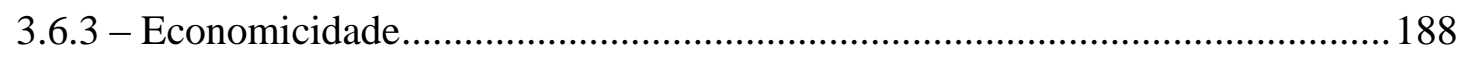

3.6.4 - Aplicação de Subvenções .......................................................................... 191

3.6.5 - Renúncia de Receitas ...................................................................................200

CAPÍTULO 4 - TRIBUNAL DE CONTAS E MINISTÉRIO PÚBLICO .......................205

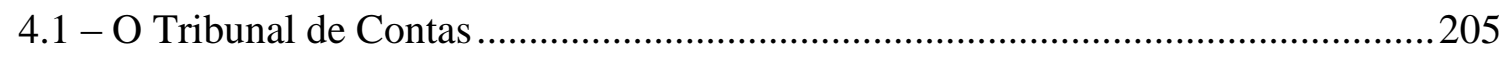

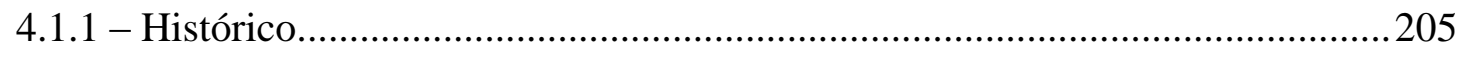

4.1.2 - O Tribunal de Contas e o perfil atual..........................................................207

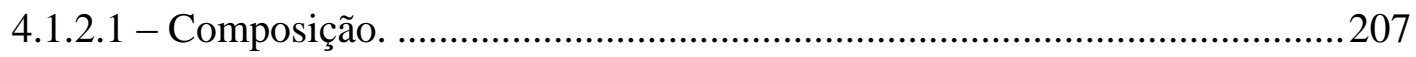

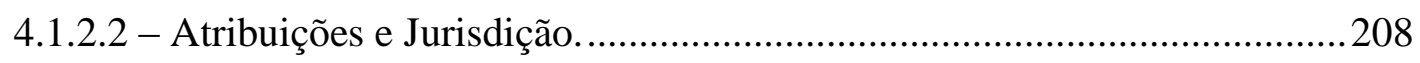

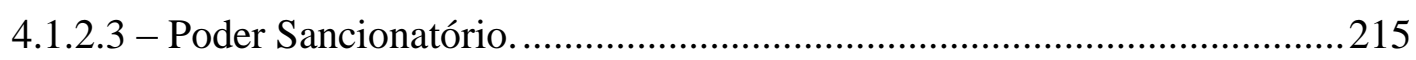

4.1.2.4 - Rede de Controle da Gestão Pública.....................................................219 
4.1.2.5 - O Tribunal de Contas de São Paulo......................................................222

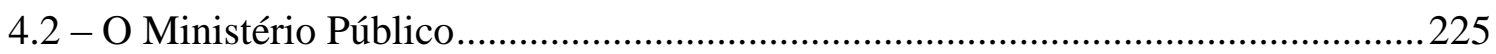

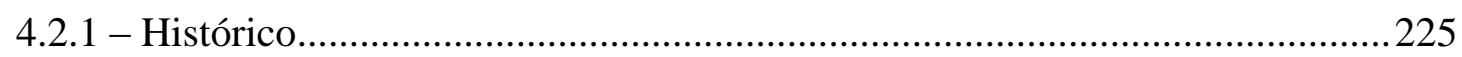

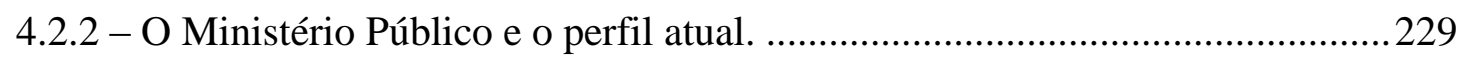

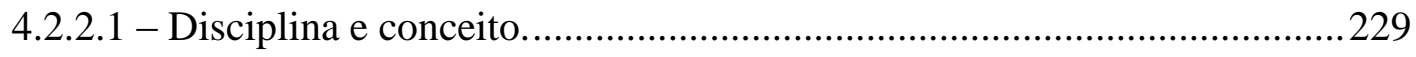

4.2.2.2 - Funções Institucionais.......................................................................23

4.2.2.3 - A fiscalização da administração pública exercida pelo Ministério Público. .234

4.2.2.4 - Condutas violadoras do Patrimônio Público e o Código Penal. .............239

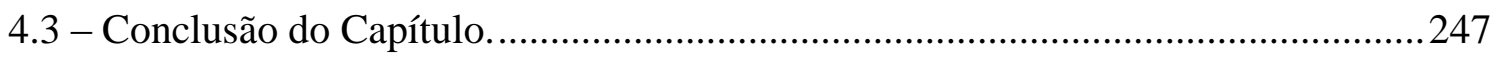

CAPÍTULO 5 - O PATRIMÔNIO PÚBLICO...............................................................2. 248

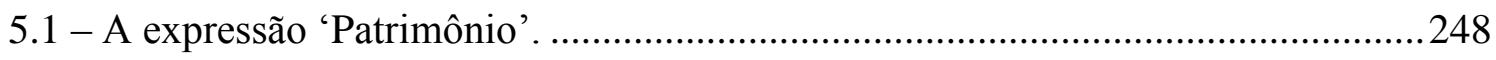

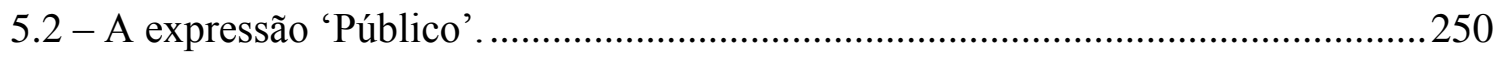

5.3 - A expressão "Patrimônio Público". ........................................................................251

5.4 - Proposta de Sistematização do Patrimônio Público................................................265

CAPÍTULO 6 - CONSIDERAÇÕES FINAIS. CONCLUSÃO ...................................2274

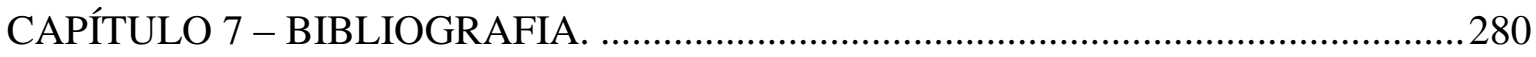

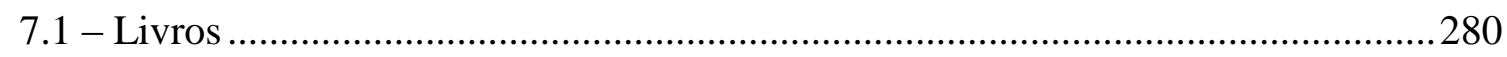

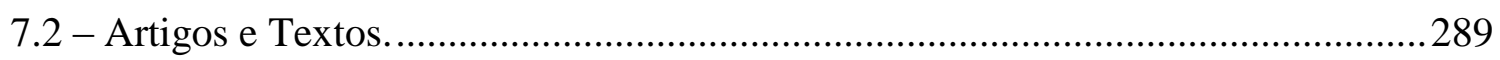

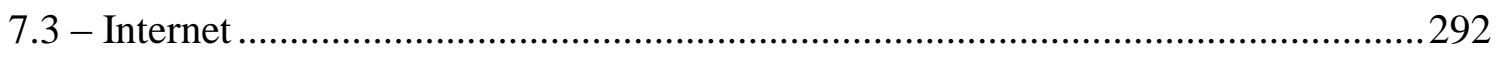

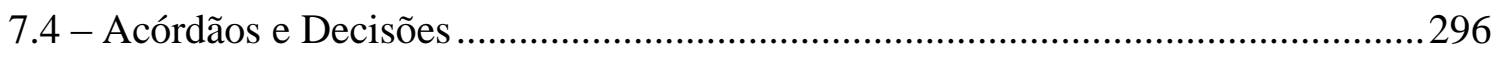

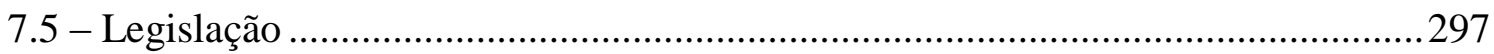




\section{$\underline{\text { OS CAPÍTULOS }}$}

O trabalho foi pensado em capítulos, em ordem didática, com escopos bem definidos, porém, sem perder a referência da ideia central, qual seja o patrimônio público e sua fiscalização.

Inicialmente, visando estabelecer o pano de fundo para o tema principal, foi feita uma breve abordagem sobre a divisão política do Estado brasileiro, com a correspondente separação de poderes, particularizando-se menção à atividade financeira e patrimonial.

A seguir foram apresentados os princípios previstos na Constituição federal e que devem nortear a atuação do administrador responsável e que servem de parâmetros para os órgãos fiscalizadores, e em sequência figura a análise da administração pública e como se dá a divisão entre administração direta e indireta e os respectivos entes de cada qual quando da descentralização administrativa.

Em sequência, o estudo está dedicado ao tema do controle e da fiscalização da administração pública, com as respectivas modalidades previstas na Constituição, a saber: contábil, financeira, orçamentária, operacional e patrimonial, esta última referida de forma especial, posto guardar nexo com o tema central do trabalho.

Discute-se quem deve prestar contas e quais os momentos em que ocorre a fiscalização, além das formas e sistemas de controle (interno e externo), não sem fugir da abordagem quanto ao uso indiscriminado dos termos 'fiscalização' e 'controle', ora como sinônimos, ora como segmentos distintos de atuação diante da atividade do poder público, mencionando-se, também, dispositivos da Lei de Diretrizes Orçamentárias de 2012 referentes ao controle do patrimônio público.

Ainda, com fulcro no art.70 da Constituição Federal, foram indicados, mesmo que de forma breve, os parâmetros nele mencionados, sobre legalidade, legitimidade, economicidade, aplicação de subvenções e renúncia de receitas, posto que indicativos quanto ao referencial a ser adotado para fiscalização do patrimônio público. 
O capítulo seguinte enfoca o Tribunal de Contas e o Ministério Público, apresentando os respectivos históricos e os contextualizando no cenário brasileiro, diante da efetiva participação como órgãos de fiscalização do patrimônio público no perfil constitucional delineado em 1988. Indica-se, no espectro de atuação de tais órgãos, desde a atividade preventiva até quais as sanções possíveis em caso de descumprimento da norma legal, seja apontando infrações administrativas punidas com multa ou sustação de contratos ou ainda os crimes contra a administração pública, com menção aos atos de improbidade administrativa, e aos delitos previstos no Código Penal quando de mácula ao patrimônio público.

Neste sentido, há que se observar que, diante da possibilidade de se verificar o patrimônio público em etapas distintas de sua existência, temos que tanto a fiscalização como o controle (considerando distingui-los pelo momento: anterior, concomitante ou posterior aos atos administrativos praticados pelo administrador público) exercem fundamental papel na correta verificação do modo de gerenciar aquele patrimônio e para tanto diversos são os mecanismos disponíveis, seja aos órgãos como Tribunal de Contas ou Ministério Público, seja ao próprio cidadão.

Após, é feita uma abordagem sobre a definição do patrimônio público, e como a doutrina considera a expressão, bem como as diversas facetas nele encontradas, ousando-se estabelecer uma proposta inovadora para formalizar a sua divisão, apontandose alguns casos práticos com decisões do Poder Judiciário e do Tribunal de Contas diante da fiscalização patrimonial da administração púbica e respectiva prestação de contas de entidades.

Finalmente, as exposições derradeiras apresentam a conclusão, mas sem esgotar o tema. Pontua-se breve distinção entre a 'Fiscalização Patrimonial da Administração Pública' e a 'Fiscalização do Patrimônio Público', reiterando-se que é preciso ter em mente que a busca de uma sociedade melhor e mais justa passa pela oportunidade do correto gerenciamento dos escassos recursos à disposição do ente detentor do Poder e que este deve se submeter ao complexo sistema de fiscalização para que desvios e abusos não aconteçam em seu mistér, sem contar que as constantes inovações tecnológicas na dinâmica sociedade atual permitem renovação da técnica e dos procedimentos, exigindo permanentes estudos para readequação dos processos. 


\section{CAPÍtulo 1 - 0 ESTADO E OS PODERES. MODELO BRASILEIRO.}

1.1 - Introdução.

Sempre que se aborda questão teórica envolvendo sociedade, não se pode deixar de mencionar que o homem, na sua essência, não vive isolado. É sabido, pela própria natureza, que o espírito humano é agregador, no sentido de infligir a necessidade da convivência

Diversas as razões, transitam pela busca de abrigo, alimento e perpetuação da espécie, além de outras.

Derivação natural é a exigência de regras de convivência, tendo em vista o surgimento de constantes conflitos, fruto de desacordos de vontades dos membros do grupo. Se no passado remoto prevalecia a força, a evolução da espécie humana levou à criação de outros mecanismos mais adequados ao estado civilizatório.

Surge a sociedade política.

O abade Emamanuel Sieyes assim tratou o tema em um panfleto, poucos meses antes da Revolução Francesa: ${ }^{1}$

“... são três épocas na formação das sociedades políticas. Na primeira, há uma quantidade de indivíduos isolados que, pelo só fato de quererem reunir-se, têm todos os direitos de uma nação, trata-se apenas de exercê-los.

Na segunda época, reúnem-se para deliberar sobre as necessidades públicas e os meios de provê-las. A sociedade política atua, então, por meio de uma vontade real comum.

\footnotetext{
1 "Que es el tercer Estado?,Madrid: Aguilar, 1973, p.73-80, conforme ainda Celso Ribeiro Bastos, Curso de direito constitucional, 12 $2^{\mathrm{a}}$ ed.São Paulo: Saraiva, 1990, p.20-23 e Alexandre Barros Castro, Processo administrativo tributário, São Paulo: Saraiva, 2008, p.2-3
} 
Todavia, por causa do grande número de associados e de sua dispersão por uma superfície demasiadamente extensa, ficam eles impossibilitados de exercer, por si mesmos a vontade comum. Assim, numa terceira época, surge o governo exercido por procuração: os associados separam tudo, o que é necessário para velar e prover as atenções públicas, e confiam o exercício dessa porção de vontade nacional, e por conseguinte de poder, a alguns dentre eles. Aqui já não atua uma vontade comum real, mas sim uma vontade comum representativa. Os representantes não exercem por direito próprio e nem sequer têm a plenitude do seu exercício...

A nação existe de tudo, é a lei mesma. Antes dela e por cima dela só existe o direito natural (...) estas leis são chamadas fundamentais não só no sentido de que possam ser feitas independentes da vontade nacional, mas sim porque os corpos que existem e atuam por elas não podem tocá-las. Em cada parte a Constituição não é obra do poder constituído, mas sim do poder constituinte. De qualquer maneira que uma nação queira, basta que queira, todas as formas são boas e sua vontade é sempre lei suprema, (...) um corpo submetido a formas constitucionais não pode decidir nada se não é segundo a Constituição”.

Portanto, se verifica que o elemento que tipifica a soberania é o poder. Não há Estado sem poder.

Passemos a trabalhar esses conceitos.

1.2 - O Estado

Estado para Balladore Pallieri ${ }^{2}$ é uma 'ordenação' que tem por 'fim' específico e essencial a regulamentação global das relações sociais entre os membros de uma dada 'população' sobre um dado 'território', onde a palavra 'ordenação' expressa a ideia de poder soberano, institucionalizado.

\footnotetext{
${ }^{2}$ Diritto constituzionale, p.14, apud José Afonso da Silva in Curso de Direito Constitucional Positivo, São Paulo: Malheiros, $26^{\mathrm{a} e d .}$. p.97
} 
Seguindo a classificação de José Afonso da Silva ${ }^{3}$ o 'Estado’ constitui-se de quatro elementos essenciais: um 'poder soberano' de um 'povo' situado num 'território' com certas 'finalidades'. Esses quatro elementos quando organizados em um conjunto de normas, formam a Constituição.

Na realidade a coletividade territorial somente adquire a qualificação de Estado se conquistar sua capacidade de autodeterminação, com independência em relação a outras coletividades com o mesmo status, vale dizer, a outros Estados.

Para ele a palavra 'País' se refere aos aspectos físicos, ao habitat, à paisagem territorial. Manifesta a unidade geográfica, histórica, econômica e cultural das terras ocupadas. O nome de um País pode ou não coincidir com o nome do Estado respectivo, mas não raro aquele é utilizado em ambos os sentidos.

Já o 'território' no dizer de Kelsen “é o âmbito de validez da ordenação jurídica chamada Estado", vale dizer, é o limite espacial dentro do qual aquele ente abstrato manifesta e exerce de modo exclusivo e efetivo o poder de império sobre a pessoas, bens e relações deles decorrentes.

Em função dele existirá um modo do exercício desse poder político a que se denomina 'forma de Estado' que pode ser unitário (quando há unidade de poder sobre território, pessoas e bens) ou composto (se existe divisão, repartição espacial de poderes em determinado espaço territorial).

Este último é que nos interessa. Chamado de Estado Federal ou Federação de Estados, remete ao modelo brasileiro.

O Federalismo, que se baseia na união de coletividades políticas autônomas, inaugurou-se como expressão de direito constitucional na Constituição norte-americana de 1787, que adotou doutrina surgida na Europa a partir dos movimentos sociais e intelectuais que pretendiam afastar o absolutismo, de onde se destaca texto da Declaração dos Direitos

\footnotetext{
${ }^{3}$ SILVA, José Afonso. Curso de Direito Constitucional Positivo. São Paulo: Malheiros, $26^{\mathrm{a}}$ Ed.

${ }^{4}$ KELSEN, Hans. Teoria general Del derecho y Del Estado. $2^{a}$ Ed., México, Imprenta Universitaria, 1958, trad. De Eduardo García-Maynez
} 
do Homem proclamada pela Revolução Francesa: "Toda sociedade onde não estiver assegurada a garantia dos direitos individuais, nem determinada a separação dos Poderes, não tem Constituição”.

\section{3 - O Estado Brasileiro}

O Brasil assumiu a forma de Estado federal em 1889, com a proclamação da República, sendo mantida tal forma nas demais constituições (apesar de constarem algumas referências doutrinárias quanto à Constituição Federal de 1967 e à emenda 1/69 quando o Federalismo limitou-se a ser nominal e não real, diante do reduzido campo de atuação aos “Estados-federados”).

A Constituição Federal de 1988, atual, manteve a forma, consoante dicção do $\operatorname{art} .1^{\circ}$ que configura o Brasil como "República Federativa". Extrai-se, ainda, do capítulo III, do Título III que as comunidades regionais autônomas são chamadas de "Estados Federados" ou simplesmente "Estados-membros" ou "Estados". Foram inseridos, também, distintos elementos, como o "Distrito Federal" e os "Territórios Federais", incluindo na estrutura político-administrativa os Municípios (arts. $1^{\circ}$ e 18).

O "Estado Federal” é dotado de personalidade jurídica de Direito Público Internacional e a "União" é a entidade federal formada pela reunião das partes componentes, sendo pessoa jurídica de Direito Público Interno, a ela cabendo exercer as prerrogativas da soberania do Estado brasileiro. Os "Estados-membros" são dotados de autonomia e de personalidade jurídica de Direito Público interno.

Os municípios estão incluídos no art. $1^{\circ}$, que prevê que o Estado brasileiro é a união indissolúvel dos Estados, Municípios e Distrito Federal, entretanto, para José Afonso da Silva ${ }^{5}$ houve equívoco do constituinte, já que município é divisão política do Estado-membro. Assim, poder-se-ia constituir dúvida se somos uma federação de Municípios e Estados ou somente de Estados. Para o autor faltariam outros elementos para caracterização de federação de municípios.

\footnotetext{
${ }^{5}$ SILVA, José Afonso. Curso de Direito Constitucional Positivo, São Paulo: Malheiros, 26aed. p.101
} 
O "Estado Federal" é o único titular da soberania, considerada o supremo poder consistente na capacidade de autodeterminação, enquanto atributo da ordem jurídica estatal interna e diante de Estados de igual poder na ordem externa; enquanto os "Estadosfederados" detém somente autonomia, assim entendida como governo próprio dentro do círculo de competências traçadas pela Constituição Federal.

Tal autonomia compreende a existência de órgãos governamentais próprios não dependentes dos órgãos federais quanto à forma de seleção e investidura e também a capacidade de deter um mínimo de competências exclusivas.

A Constituição Federal de 1988 procurou estabelecer um equilíbrio nas relações entre o poder central e os poderes estaduais e municipais, o que, entretanto, na prática não se verifica, sendo a questão complexa e alvo de discussões alhures, visto que o exercício efetivo do Poder implica não somente na forma de concepção e distribuição das funções estatais, mas também na obtenção de recursos, valores econômicos, financeiros e patrimoniais, permissivos do desenvolver de políticas a serem adotadas em prol do grupo social.

Prevê, ainda, a Constituição Federal, no art.2 ${ }^{\circ}$ que são Poderes da União, independentes e harmônicos entre si, o Legislativo, o Executivo e o Judiciário. As expressões indicam tanto as funções (legislativa, executiva e jurisdicional, que remontam às proposições de Aristóteles) como os respectivos órgãos conforme estabelecido no Título IV - Da Organização dos Poderes.

\section{4 - O Poder}

Entender a palavra "Poder" como um fenômeno sócio-cultural e um fato da vida social nos faz admitir que pertencer a um grupo social também é reconhecer que o grupo pode exigir determinados atos e condutas conforme fins almejados, pode impor esforços e sacrifícios, fixar limites aos desejos e intenções, e indicar formas de agir diante de situações postas. "Poder" para Jean-William Lapierre ${ }^{6}$ é uma energia capaz de coordenar e impor decisões visando à realização de determinados fins.

\footnotetext{
${ }^{6}$ LA PIERRE, Jean-William. Le pouvoir politique, Paris, PUF, Collection Que saisje?, 1953, p.5
} 
Para Celso Ribeiro Bastos ${ }^{7}$ sem o Poder não existiria ordem, organização dentro de uma sociedade e esta rumaria ao caos. O fenômeno é bilateral, pois decorre da união de duas ou mais vontades, sendo que uma sempre prevalece sobre a outra, sendo essencial para a organização do Estado.

Entretanto, é certo que se o Estado, que carece de vontade própria e que se manifesta por meio de seus órgãos, que em última instância exprimem a vontade da coletividade, vontade humana, portanto, pudesse exercer o Poder de forma concentrada, não estaria atendendo os anseios do grupo a que deve servir, na medida em que não permite a captação de todas as vontades.

Detém ele o chamado 'poder político' ou 'poder estatal' que é superior aos outros poderes sociais (que ainda que reconhecidos, não prevalecem se em conflito, como o poder religioso, o familiar, o sindical etc.) e na evolução do pensamento doutrinário atingimos o atual estágio em que há uma repartição no exercício de tal 'poder' que consiste no estabelecimento de mecanismos de equilíbrio e controle recíproco das funções principais do 'poder estatal'.

O Brasil adotou, assim como grande parte das nações ocidentais, o modelo derivado inicialmente do pensamento de Aristóteles, que retomado nos séculos XVII e XVIII por Locke, Rousseau, Bolinbroke e Montesquieu redundou na admissão de que são três funções essenciais em qualquer Estado: a legislativa, a executiva e a judiciária, que devem ser exercidas por órgãos próprios, de forma autônoma e independente.

Basicamente, conforme ensina Celso $\operatorname{Bastos}^{8}$ a função legislativa consiste em estabelecer normas gerais e abstratas que regem a vida em sociedade, a executiva em traduzir num ato de vontade individualizado a exteriorização abstrata da lei e a jurisdicional em dirimir possíveis controvérsias que possam surgir por ocasião da aplicação da norma.

\footnotetext{
${ }^{7}$ BASTOS, Celso Ribeiro. Curso de Teoria do Estado e Ciência Política, Saraiva: São Paulo, $4^{a}$ Ed., 1999, p.76

${ }^{8}$ BASTOS, Celso Ribeiro. Curso de Teoria do Estado e Ciência Política, Saraiva: São Paulo, $4^{a}$ Ed., 1999, p. $152 / 153$
} 
Na prática, o tema é mais complexo, na medida em que o exercício contínuo das funções mostrou que nenhum dos poderes que, respectivamente, as exercem é totalmente autônomo e independente. Além dos mecanismos de controle recíproco, cada qual, em determinado momento, exerce função distinta daquela originária, enquanto que conforme se verá mais adiante - a Constituição Federal inseriu novos atores na cena do exercício do Poder que, ainda que não classificados como tal, detém autonomia diante daqueles três mencionados, como o Ministério Público e o Tribunal de Contas.

Vê-se que o Princípio da Tripartição de Poderes do Estado já não possúi a mesma rigidez de outrora, tendo em vista a ampliação das atividades do Estado moderno e contemporâneo, bem como das novas formas de relacionamento entre os seus entes. Ademais, há que se agregar à função estatal a de controle, que segundo Karl Loewenstein ${ }^{9}$, é essencial à teoria do poder.

Ainda Celso Bastos ${ }^{10}$ menciona que de acordo com Loewenstein o Estado teria suas funções divididas em: “ a) policy determination, a decisão política fundamental; b) policy execution, que é a execução dessa decisão política fundamental, viabilizada pela legislação, administração e jurisdição; e c) policy control, a fiscalização política.”.

Nessa função de controle exercida pelos magistrados residiria a distância para a concepção de Montesquieu que considerava a atividade judicial submetida à legislativa e governativa, enquanto Loewenstein considerando a 'radical transformação' na função jurisdicional elenca funções de controle a serem desempenhadas: "1) El derecho de los tribunales a supervisionar y comprobar la concordancia de las acciones del poder ejecutivo com su base legal. 2) La competência judicial para El control de la constitucionalidad de las leyes emitidas por el gobierno y el parlamento. 3) Em algunos ordenes jurídicos La decisión arbitral sobre conflictos que se puedan producir em el ejercicio de las funciones asignadas a los otros detentadores Del poder. Esta última evolución se designa frecuentemente como Judicialización, o Justicialización de La Política”.

\footnotetext{
${ }^{9}$ Teoria de La Constitución, p.305, apud BASTOS, Celso Ribeiro. Curso de Teoria do Estado e Ciência Política, Saraiva: São Paulo, $4^{a}$ Ed., 1999, p.161.

${ }^{10}$ BASTOS, Celso Ribeiro. Curso de Teoria do Estado e Ciência Política, Saraiva: São Paulo, $4^{\text {a }}$ Ed., 1999, p.160;162.
} 
Fato é que no Brasil a função do controle foi reconhecida e alçada ao nível constitucional, se encontrando repartida em vários órgãos estatais, dentre os quais temos a atuação dos Tribunais de Contas (prevista nos artigos 70 a 75 da Constituição Federal) e o que foi elencado como função institucional do Ministério Público (conforme art. 129 da Constituição Federal), assunto que será objeto de aprofundamento em capítulo próprio.

Sem a função do controle, a atividade dos entes e dos administradores públicos ficaria como que à vontade, com consequências evidentemente nefastas à sociedade diante da ausência de mecanismos de freios e contrapesos. Assim também, o controle sem disciplina poderia levar a desequilíbrios, com os órgãos controladores substituindo-se aos próprios controlados.

Portanto, vê-se que necessária é a função do controle da atividade pública, mas com os parâmetros devidamente alinhavados nos textos legais, para que possam acontecer tanto em caráter preventivo e orientador, como também repressivo.

Mais adiante será visto o exercício de tal função essencial ao funcionamento da máquina pública, em especial no tema patrimonial, e em particular porque se constituiu em elemento central da ideia acerca da realização da função pública frente aos anseios sociais, momento em que se faz necessário o correto manejo e emprego dos recursos financeiros e patrimoniais estatais à disposição dos administradores.

1.5 - Recursos do Estado

Não existe atividade humana que se possa realizar sem que se detenham recursos para tanto. Podem ser de distintas ordens, seja na esfera absolutamente individual, seja na coletiva, assim como os recursos podem ser de diferentes naturezas.

Neste sentido, o termo 'recursos' pode ser estendido em seu entendimento até mesmo como determinada capacidade que alguém tem ou não de realizar tal ou qual ato. Porém, não se pode perder de vista que mesmo detendo capacidade (raiz subjetiva) precisa de elementos (objetivos) para o que pretende. Assim, os 'recursos' podem ser concretos ou abstratos, sendo aqueles os referentes a bens, dinheiros e assemelhados, em 
uma unidade patrimonial e estes os relativos às competências para exercício de determinadas ações.

Entretanto, quando se fala em atividade do poder público e se tem que sua função essencial é o atendimento das necessidades sociais, se torna inevitável admitir que haja íntima ligação entre a possibilidade de se realizar aquele escopo e a disponibilidade de recursos financeiros e patrimoniais aliados ao seu correto manejo.

Tanto é que a Lei de Diretrizes Orçamentárias (Lei n ${ }^{\circ} 12.708$ de 17 de agosto de 2012) prevê no artigo 11 que a Mensagem que encaminhar o Projeto de Lei Orçamentária de 2013 conterá o resumo da política econômica do País, a análise da conjuntura econômica e atualização das informações de que trata o $\S 4^{\circ}$ do art. $4^{\circ}$ da Lei de Responsabilidade Fiscal, com indicação do cenário macroeconômico para 2013, e suas implicações sobre a Proposta Orçamentária de 2013; o resumo das políticas setoriais do governo; a avaliação das necessidades de financiamento do Governo Central relativas aos Orçamentos Fiscal e da Seguridade Social, explicitando receitas e despesas e os resultados primário e nominal implícitos no Projeto de Lei Orçamentária de 2013, na Lei Orçamentária de 2012 e em sua reprogramação e os realizados em 2011, de modo a evidenciar tanto a metodologia de cálculo de todos os itens computados na avaliação das necessidades de financiamento como os parâmetros utilizados, informando, separadamente, as variáveis macroeconômicas de que trata o Anexo de Metas Fiscais referido no inciso II do $\S 2^{\circ}$ do art. $4^{\circ}$ da Lei de Responsabilidade Fiscal, verificadas em 2011 e suas projeções para 2012 e 2013.

Também conterá a indicação do órgão que apurará os resultados primário e nominal, para fins de avaliação do cumprimento das metas; a justificativa da estimativa e da fixação, respectivamente, dos principais agregados da receita e da despesa; e o demonstrativo sintético, por empresa, do Programa de Dispêndios Globais, informando as fontes de financiamento, com o detalhamento mínimo igual ao estabelecido no $\S 3^{\circ}$ do art. 36, bem como a previsão da sua respectiva aplicação, além do resultado primário dessas empresas com a metodologia de apuração do resultado. 
Vale dizer, dos elementos exigíveis para a consecução da função estatal necessariamente estarão presentes os recursos financeiros e patrimoniais à disposição do administrador público, assim como da ação deste diante daqueles recursos derivará o sucesso da política pública a ser implementada.

Neste cenário, exigível será a prestação de contas e a fiscalização, como aqui se estudará. 


\title{
CAPÍTULO 2 - A ADMINISTRAÇÃO PÚBLICA.
}

\author{
2.1 - Estado e Administração Pública
}

Relembrando a afirmação sobre a natureza social do homem, sejam pelos interesses familiares, materiais ou ainda objetivos espirituais, proteção, alimentação, sobrevivência etc, fato é que o tempo fez com que surgisse a sociedade política com o Estado.

Tal ente abstrato existe em função da necessidade de convivência entre os seres humanos em uma determinada coletividade e da exigência de instituições que balizem aquela convivência estabelecendo os comportamentos aceitáveis ou não e as sanções respectivas para os casos não aceitos.

Sabendo-se que a doutrina indica como elementos constitutivos do Estado o povo, o território e um governo e que aponta objetivos (inserindo conceitos de finalidade e

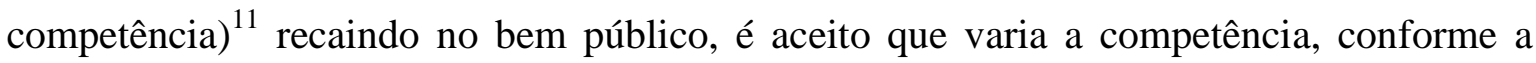
época, o lugar, e a escolha de determinada comunidade sobre a quem competirá realizar tais ou quais serviços, e assim, afirma-se que os objetivos escolhidos, para que sejam realizados, exigem que a sociedade detenha mecanismos de verificação quanto à eficácia e eficiência dos instrumentos disponíveis na busca efetiva de sua realização.

O poder político e a autoridade do Estado recaem no governo e há diversas formas pelas quais ele pode se organizar, determinando assim a situação jurídica e social dos indivíduos em relação àquela autoridade. A forma do Estado (simples ou composto) se configura conforme será exercido o poder político no âmbito de seu território.

Por outro lado, o Estado, para atingir seus fins exercita o poder por meio da competência, efetuando serviços e atividades que variam no tempo e no espaço, visando à realização do bem comum.

\footnotetext{
${ }^{11}$ Darcy Azambuja refere que a quase totalidade dos doutrinadores confunde os conceitos de fim e de competência do Estado. O fim do Estado é o objetivo que ele visa atingir quando exerce o poder. Este objetivo é invariável e é o bem público. AZAMBUJA, Darcy, Teoria Geral do Estado. $4^{\mathrm{a}}$ ed. Porto Alegre: Globo, 1963, p.3.
} 
A complexidade das relações no mundo moderno leva à conclusão que também são complexas as atuais atividades estatais, em especial em face das necessidades cada vez mais intensas e difíceis da sociedade. Assim, a atividade estatal exige uma estrutura bem delineada que permita a realização de suas funções, em especial as três básicas: legislativa, executiva e judiciária.

Aqui, reitera-se, como dito no início do trabalho, que não é intenção aprofundar a discussão doutrinária acerca da divisão de poderes ou de funções de poder desde a clássica tripartição de Montesquieu - porém não se pode afastar a noção de que o poder do Estado é uno e indivisível desdobrando-se em funções (em especial as três mencionadas) e que tomam destinação a organismos distintos (que recebem a denominação das respectivas funções).

2.1.1 - A tripartição de poderes.

A Constituição Federal de 1988 estabeleceu que são objetivos fundamentais da República Federativa do Brasil: construir uma sociedade livre, justa e solidária; garantir o desenvolvimento nacional; erradicar a pobreza e a marginalização e reduzir as desigualdades sociais e regionais; promover o bem de todos, sem preconceitos de origem, raça, sexo, cor idade e quaisquer outras formas de discriminação (art. $3^{\circ}$, I a IV) e também aponta que "são Poderes da União, independentes e harmônicos entre sí, o Legislativo, o Executivo e o Judiciário" (art. $2^{\circ}$ ).

Portanto, optando o Brasil pela separação tripartite de poder, temos que são independentes porque cada qual desempenha sua atividade com exclusividade funcional; com a investidura dos cargos em um órgão ou no próprio Poder, acontecendo sem dependência da confiança ou da vontade do outro; e possuindo autonomia para elaboração e execução do orçamento, juntamente com a autonomia administrativa.

Também harmônicos porque devem respeito mútuo às prerrogativas funcionais de cada qual, sempre no direcionamento da consecução dos fins do Estado. Cabe afirmar que a independência harmônica não é absoluta, na medida em que admite 
algumas interferências, com aceitação de um sistema de freios e contrapesos - que, na prática, pode-se dizer que é o 'controle do poder pelo próprio poder'.

Para que tal poder seja efetivo, há necessidade de existir uma organização administrativa no sentido de permitir ao Estado, por meio de entidades e órgãos - que por sua feita agem por intermédio de seus agentes públicos - que possa desempenhar suas funções na realização de seus fins.

O Poder Executivo detém a predominância da função administrativa, porém os demais também possuem funções típicas de administração. Por outro lado, o Estado pode desenvolver diretamente as atividades administrativas que lhe são próprias, como ainda por intermédio de outras entidades criadas para o desenvolvimento das funções administrativas, e cuja previsão seja constitucional. Tais entidades podem ter personalidade jurídica de direito público ou privado.

Diz-se que a atividade administrativa é realizada de forma centralizada ou descentralizada, sendo aquela a atuação direta do Estado por meio de seus órgãos, das unidades que são repartições interiores de sua pessoa, sem dela se distinguirem e esta a que acontece por meio de outras pessoas juridicamente distintas do próprio Estado, mas ainda criaturas suas, constituindo parcela da totalidade do aparelho administrativo estatal ${ }^{12}$.

Independentemente das classificações, fato é que se pode discutir a divisão ou a atribuição, mas em quaisquer delas, tanto o Estado, por meio dos entes, como os indivíduos, que agem no exercício de parcela do Poder a eles conferido pela sociedade, devem ter parâmetros para atuar.

Estes, por sua vez são fixados em normas constitucionais e/ou infraconstitucionais.

12 BANDEIRA DE MELLO, Celso Antonio. Curso de direito administrativo .4.ed.. São Paulo: Malheiros, 1993, p.70 


\subsection{2 - Princípios Constitucionais}

Papel importante neste cenário desempenha a questão dos princípios.

Charles Debbasch ${ }^{13}$ aponta que os princípios gerais do direito são as mais importantes fontes de legalidade no direito administrativo francês, derivados dos fundamentos de seu direito público, refletidos particularmente na Declaração dos Direitos do Homem de 1789 ou nos preâmbulos constitucionais, sendo seu reconhecimento como regra de direito indispensável para completar o quadro jurídico dentro do qual deve desenvolver-se a nação e atuar as instituições políticas e econômicas, e cuja violação traz a mesma consequência da violação à lei.

Extraído da doutrina alemã temos que Alexy ${ }^{14}$ conceitua que “... princípios são normas que ordenam que algo seja realizado na maior medida possível dentro das possibilidades jurídicas e fáticas existentes. Princípios são mandamentos de otimização, que são caracterizados por poderem ser satisfeitos em graus variados e pelo fato de que a medida devida de sua satisfação não depende somente das possibilidades fáticas, mas também das possibilidades jurídicas".

Hélio Milesky ${ }^{15}$ refere que "Princípios constitucionais são padrões de conduta que devem ser seguidos pela Administração Pública, constituindo arcabouço dos fundamentos de validade da ação administrativa"..

Para José Afonso da Silva ${ }^{16}$ : "os princípios são ordenações que se irradiam e imantam os sistemas de normas, são (como observam Gomes Canotilho e Vital Moreira) núcleos de condensações nos quais confluem valores e bens constitucionais. Mas como disseram os mesmos autores, os princípios que começam por ser a base de normas jurídicas, podem estar positivamente incorporados, transformando-se em normasprincípio e constituindo preceitos básicos da organização constitucional”.

\footnotetext{
${ }^{13}$ DEBBASCH, Charles. Institutions et droit administratifs, Paris: PUF, 1956, p.266-75

${ }^{14}$ ALEXY, Robert. Teoria dos Direitos Fundamentais. Trad. Virgílio Afonso da Silva. São Paulo: Malheiros, 2008. P.90

${ }^{15}$ MILESKY, Helio Saul, O controle da gestão pública. São Paulo: RT, 2003, p.37

${ }^{16}$ SILVA, José Afonso. Curso de Direito Constitucional Positivo.15. ed. São Paulo: Malheiros, 1998. p.112
} 
E mais analiticamente encontramos em Humberto Ávila" que "Os princípios são normas imediatamente finalísticas, primariamente prospectivas e com pretensão de complementaridade e de parcialidade, para cuja aplicação se demanda uma avaliação da correlação entre o estado de coisas a ser promovida e os efeitos decorrentes da conduta havida como necessária à sua promoção.

É possível afirmar que, em razão do Estado Democrático de Direito, a administração pública está adstrita ao cumprimento e obediências dos princípios insertos na Constituição Federal, como a supremacia do interesse público sobre o interesse privado - como princípio geral de direito - e ainda aos demais traçados em especial no art. 37 da Carta magna:

Art. 37. A administração pública direta e indireta de qualquer dos Poderes da União, dos Estados, do Distrito Federal e dos Municípios obedecerá aos princípios de legalidade, impessoalidade, moralidade, publicidade e eficiência...

O mesmo artigo apresenta outras disposições que permitem verificar contornos para atuação do administrador público, como por exemplo, os parágrafos $4^{\circ}$ a $9^{\circ}$ que disciplinam que os atos de improbidade administrativa importarão a suspensão dos direitos políticos, a perda da função pública, a indisponibilidade dos bens e o ressarcimento ao erário, na forma e gradação previstas em lei, sem prejuízo da ação penal cabível; que deverão ser estabelecidos os prazos de prescrição para ilícitos praticados por qualquer agente, servidor ou não, que causem prejuízos ao erário, ressalvadas as respectivas ações de ressarcimento; que as pessoas jurídicas de direito público e as de direito privado prestadoras de serviços públicos responderão pelos danos que seus agentes, nessa qualidade, causarem a terceiros, assegurado o direito de regresso contra o responsável nos casos de dolo ou culpa; que deverão ser fixados pelo legislador os requisitos e as restrições ao ocupante de cargo ou emprego da administração direta e indireta que possibilite o acesso a informações privilegiadas.

\footnotetext{
${ }^{17}$ ÁVILA, Humberto Bergmann. Teoria dos Princípios. Da definição à aplicação dos princípios jurídicos. $9^{a}$ ed. São Paulo: Malheiros, 2009. p.78-79
} 
Também que a autonomia gerencial, orçamentária e financeira dos órgãos e entidades da administração direta e indireta poderá ser ampliada mediante contrato, a ser firmado entre seus administradores e o poder público, que tenha por objeto a fixação de metas de desempenho para o órgão ou entidade, cabendo à lei infraconstitucional dispor sobre o prazo de duração do contrato, os controles e critérios de avaliação de desempenho, direitos, obrigações e responsabilidade dos dirigentes e a remuneração do pessoal.

Há comando sobre a questão remuneratória que diz que a remuneração e o subsídio dos ocupantes de cargos, funções e empregos públicos da administração direta, autárquica e fundacional, dos membros de qualquer dos Poderes da União, dos Estados, do Distrito Federal e dos Municípios, dos detentores de mandato eletivo e dos demais agentes políticos e os proventos, pensões ou outra espécie remuneratória, percebidos cumulativamente ou não, incluídas as vantagens pessoais ou de qualquer outra natureza, não poderão exceder o subsídio mensal, em espécie, dos Ministros do Supremo Tribunal Federal, aplicando-se como limite, nos Municípios, o subsídio do Prefeito, e nos Estados e no Distrito Federal, o subsídio mensal do Governador no âmbito do Poder Executivo, o subsídio dos Deputados Estaduais e Distritais no âmbito do Poder Legislativo e o subsídio dos Desembargadores do Tribunal de Justiça, limitado a noventa inteiros e vinte e cinco centésimos por cento do subsídio mensal, em espécie, dos Ministros do Supremo Tribunal Federal, no âmbito do Poder Judiciário, aplicável este limite aos membros do Ministério Público, aos Procuradores e aos Defensores Públicos ${ }^{18}$.

E aplica-se o mesmo sistema às empresas públicas e às sociedades de economia mista, e suas subsidiárias, que receberem recursos da União, dos Estados, do Distrito Federal ou dos Municípios para pagamento de despesas de pessoal ou de custeio em geral.

Em obediência à norma maior, a Lei no 12.708 de 17 de agosto de 2012 (Lei de Diretrizes Orçamentárias - LDO) indica no art. 118 que a execução da Lei Orçamentária de 2013 e dos créditos adicionais obedecerá aos princípios constitucionais da legalidade, impessoalidade, moralidade, publicidade e eficiência na administração pública federal, não

\footnotetext{
${ }^{18}$ Art. 31, XI da CF
} 
podendo ser utilizada para influir na apreciação de proposições legislativas em tramitação no Congresso Nacional.

Cabe, neste momento, estudar, ainda que de modo perfunctório, cada um dos princípios constantes do art. 37 da Constituição Federal, na medida em que são indicativos de limites para atuação do administrador público e consequentemente servem de parâmetros para a fiscalização de sua atividade.

\subsubsection{1 - Legalidade}

Hely Lopes Meirelles ensina "que o administrador público está, em toda a sua atividade funcional, sujeito aos mandamentos da lei e às exigências do bem comum, $e$ deles não se pode afastar ou desviar, sob pena de praticar ato inválido e expor-se a responsabilidade disciplinar, civil e criminal, conforme o caso. (...) A eficácia de toda atividade administrativa está condicionada ao atendimento da lei. (...) Na Administração Pública não há liberdade nem vontade pessoal. Enquanto na administração particular é lícito fazer tudo que a lei não proíbe, na Administração Pública só é permitido fazer o que a lei autoriza". 19

Segundo Maria Sylvia Zanella Di Pietro ${ }^{20}$, ao afirmar que a legalidade foi trazida pela ordem da Constituição Federal de 1988 como uma expressiva garantia do respeito aos direitos da esfera individual: "Este princípio, juntamente com o de controle da Administração pelo Poder Judiciário, nasceu com o Estado de Direito e constitui uma das principais garantias de respeito aos direitos individuais. Isso porque a lei, ao mesmo tempo em que os define, estabelece também os limites da atuação administrativa que tenha por objeto a restrição ao exercício de tais direitos em beneficio da coletividade."

E Celso Antônio Bandeira de Mello ${ }^{21}$ considera o princípio da legalidade um dos elementares dentre os que regem a atividade da Administração Pública: “... é $o$ princípio basilar do regime jurídico-administrativo, já que o Direito Administrativo nasce com o Estado de Direito: é uma conseqüência dele. É o fruto da submissão do Estado à

${ }^{19}$ MEIRELLES, Hely Lopes, Direito administrativo brasileiro, 24a edição, São Paulo, 1999, p. 82

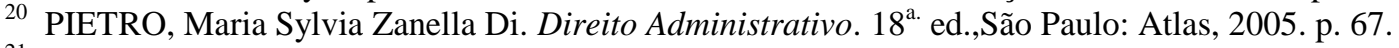

21 MELlo, Celso Antônio Bandeira de. Curso de Direito Administrativo. 15 ${ }^{\text {a }}$ ed. São Paulo: Editora Malheiros, 2003. p. 91. 
lei. É, em suma, a consagração da idéia de que a Administração Pública só pode ser exercida na conformidade da lei e que, de conseguinte, a atividade administrativa é atividade sublegal, infralegal, consistente na expedição de comandos complementares à lei... Para avaliar corretamente o princípio da legalidade e captar-lhe o sentido profundo cumpre atentar para o fato de que ele é a tradução jurídica de um propósito político: o de submeter os exercentes do poder em concreto - o administrativo - a um quadro normativo que embargue favoritismos, perseguições ou desmandos. ”.

Assim, pode se extrair que o princípio da legalidade deve ser compreendido como uma ferramenta necessária para a promoção da atividade administrativa livre de arbítrios ou abusos, bem como para fazer seguir os parâmetros que o nosso sistema jurídico impõe para o regular exercício das funções dos agentes públicos ${ }^{22}$, que somente podem atuar nos estritos ditames da lei.

Não se confunde com a própria lei e vai além das prescrições do poder legiferante, tanto diante de eventual delegação legislativa como pela densa relação contratual entre a Administração Pública e os administrados. Assim, contempla o princípio da legalidade outros instrumentos de caráter normativo, como, por exemplo, decretos ou agências reguladoras quando do exercício de seu poder normativo técnico.

Recorde-se sempre que, enquanto nas relações entre particulares se aplica o princípio da autonomia da vontade, o que significa que podem fazer tudo aquilo que a lei não pró́be, à Administração Pública só se autoriza a prática dos atos permitidos por lei.

A título de exemplo, consta recente decisão (julgado em 13/03/2012) do Supremo Tribunal Federal nos autos do agravo de instrumento $\mathrm{n}^{\circ}$ AI 837555 de relatoria do Ministro Luiz Fux (em que afasta recurso especial para rever prova), que existe legitimidade do Ministério Público (tema que será aprofundado adiante) na proteção do patrimônio público quando da violação do princípio da legalidade ${ }^{23}$.

22 LIMA, Raimundo Márcio Ribeiro. Premissas principiológicas e garantísticas indispensáveis a uma regular atuação da administração pública e o silêncio administrativo. Revista a Advocacia Geral da União, Ano X, nº 28. Brasilia-DF, abr.jun. 2011. p. 252

23 Ementa: Agravo Regimental no Agravo de Instrumento. Processual Civil. Ação Civil Pública. Legitimidade do Ministério Público. Art. 129, III, da CF. PROTEÇÃO AO PATRIMÔNIO PÚBLICO. Eletropaulo. Contratação de mão-de-obra. Ausência de procedimento licitatório. Empresa pública à época da assinatura do contrato. Participação majoritária do Estado de São Paulo no Capital Social. Lei No 98.666/93, 


\subsubsection{2 - Impessoalidade}

Significa que deve ser imposto tratamento objetivo e imparcial dos agentes públicos sobre as questões a serem decididas ou acerca das medidas a serem tomadas no exercício de suas funções. Busca-se uma atuação livre de favorecimentos ilegais ou ilegítimos, vale dizer, que afronte a igualdade de tratamento a ser dispensada a todos os administrados.

Assim, a gestão da coisa pública deve ser feita no exclusivo interesse da cidadania e não por preferências ou animosidades pessoais. A razão de agir do administrador haverá sempre de ser de interesse público relevante, não sendo tolerados privilégios em favor de simpatizantes, correligionários ou amigos, bem como não se tolerando perseguições pessoais ou de índole política. ${ }^{24}$.

Para Emerson Garcia 25 "Tal princípio, previsto no art. 37, 'caput' e $\S 1^{\circ} d a$ Constituição, deve ser concebido em uma dupla perspectiva. Em um primeiro sentido, estatui que o autor dos atos estatais é o órgão ou a entidade, e não a pessoa do agente (acepção ativa). Sobre outra ótica, torna cogente que a Administração dispense igualdade de tratamento a todos aqueles que se encontrem em posição similar, o que pressupõe que

Art.. 24, I e XXVI. Necessidade de Licitação. Alegação de afronta aos artigos $5^{\circ}$, LIV e LV, 37, § 5, II e XIX, 127, caput, e 129, III e IX, da Carta Federal. Ofensa reflexa. Matéria fática. Súmula $n^{\circ}$ 279/STF. Decisão que se mantém por seus próprios fundamentos.1.A violação reflexa e oblíqua da Constituição Federal decorrente da necessidade de análise de malferimento de dispositivo infraconstitucional torna inadmissível o recurso extraordinário. Precedentes. 2. Legitimatio ad causam do Ministério Público à luz da dicção do art. 129, III, da C.F/1988, que o habilita a demandar em prol do patrimônio público. Precedentes: RE 459.138-AgR, Rel Min. GILMAR MENDES, 2a Turma, DJ 25.4.2008; RE 262.134-AgR, Rel. Min. CELSO DE MELLO, $2^{\mathrm{a}}$ Turma, DJ 2.2.2007; AI 495.632-AgR, Rel. Min. SEPÚLVEDA PERTENCE, $1^{\mathrm{a}}$ Turma, DJ 16.6.2006;AI 244.217- AgR, Rel. Min. EROS GRAU, 1 ${ }^{\text {a }}$ Turma, DJ 25.11.2005. 3. Os princípios da legalidade, do devido processo legal, da ampla defesa e do contraditório, da motivação das decisões judiciais, bem como os limites da coisa julgada, quando a verificação de sua ofensa dependa do reexame prévio de normas infraconstitucionais, revelam ofensa indireta ou reflexa à Constituição Federal, o que, por si só, não desafia a abertura da instância extraordinária. Precedentes. 4. A Súmula 279/STF dispõe verbis: Para simples reexame de prova não cabe recurso extraordinário. 5. É que o recurso extraordinário não se presta ao exame de questões que demandam revolvimento do contexto fático-probatório dos autos, adstringindo-se à análise da violação direta da ordem constitucional. 6. In casu, o acórdão recorrido assentou: AÇÃO CIVIL PÚBLICA Improbidade ELETROPAULO. Empresa controlada pelo Estado Dispensa de licitação para contratação de mão-de-obra complementar. Emergência. - Ação procedente Declaração de nulidade contratual e condenação na indenização da taxa de administração, solidariamente Agravo retido desprovido Preliminares rejeitadas Sentença mantida Recursos desprovidos. 7. Agravo Regimental a que se nega provimento. - Negritos não originais. Acesso em 27/08/12 in:

http://www.stf.jus.br/portal/jurisprudencia/visualizarEmenta.asp?s1=000185964\&base=baseAcordaos

${ }^{24}$ COELHO, Paulo Magalhães da Costa. Controle Jurisdicional da Administração Pública. São Paulo: Saraiva, 2002. p. 30

${ }^{25}$ GARCIA, Emerson. O Ministério Público e a Defesa do Princípio da Impessoalidade. Revista dos Tribunais, vol. 799, p.147, maio 2002. 
os atos praticados gerem os mesmos efeitos e atinjam a todos os administrados que estejam em idêntica situação fática ou jurídica, caracterizando a imparcialidade do agente público (acepção passiva). Com isto preserva-se o princípio da isonomia entre os administrados e o princípio da finalidade, segundo o qual a atividade estatal deve ter sempre por objetivo a satisfação do interesse público, sendo vedada qualquer prática que busque unicamente a implementação de um interesse particular. .".

E para Juarez de Freitas ${ }^{26}$ “... a Administração Pública precisa dispensar tratamento isonômico a todos, sem privilégios espúrios, tampouco manobras persecutórias, sequer as movidas por supostas boas intenções. Intenta-se a instauração, acima de sinuosos personalismos, do governo dos princípios e dos objetivos fundamentais, em lugar do idiossincrático império 'emotivistas' dos projetos de cunho faccioso, antagônicos, por definição, à filosofia da boa administração”.

Portanto, a impessoalidade não se vincula à indiferença na consecução do serviço público, mas sim impõe o dever de uma atuação prestativa e que seja ausente de favorecimento ou benefício sem amparo legal, lembrando que a atividade exercida para a promoção dos misteres da Administração Pública é atribuída ao órgão antes de o ser ao servidor, pessoa física.

Em julgamento de ação direta de inconstitucionalidade ${ }^{27}$ quando foi alegada afronta aos arts. 52, incisos VI a IX; 173, §§ $1^{\circ}$ a $5^{\circ}$.; 37; e 170, IV, da Constituição Federal pelo texto da Lei n. 8388, de 30 de dezembro de 1991, que disciplinava a consolidação e reescalonamento de dívidas dos Estados, do Distrito Federal e dos Municípios, o STF decidiu pela inexistência de plausibilidade para a tese de usurpação da competência do Senado Federal, no que concerne ao controle, que lhe cabe, com exclusividade, do endividamento das entidades publicas interessadas.

\footnotetext{
${ }^{26}$ FREITAS, Juarez. $O$ controle dos atos administrativos $e$ os princípios fundamentais. $4^{\mathrm{a}}$ ed. São Paulo: Malheiros, 2009. p. 82

${ }^{27}$ ADI 688 MC, Relator: Min. ILMAR GALVÃO, Tribunal Pleno, julgado em 26/03/1992, DJ 07-05-1993 PP-08326 EMENT VOL-01702-02 PP-00225, in: http://www.stf.jus.br/portal/jurisprudencia/visualizarEmenta.asp?s1=000105522\&base=baseAcordaos
} 
Indicou que, não obstante os entes da administração indireta, contemplados pelo diploma legal impugnado, fossem pessoas jurídicas de direito privado, deteriam apreciáveis parcelas do patrimônio público, incumbindo-lhes sua proteção, justificando-se por esse modo, o tratamento especial que lhes dispensou a lei. Admitindo a importância do princípio da impessoalidade, apontou que não houve ofensa posto que o caso concreto não contemplava nenhuma entidade ou pessoa em particular, não foi dado nenhum benefício que não estivesse previsto em lei e que em momento algum se esteve diante de favores descabidos ou diante da dominação de mercados, da eliminação de concorrentes ou do aumento arbitrário de lucros.

\subsubsection{3 - Moralidade}

Celso Antonio Bandeira de $\mathrm{Mello}^{28}$ afirma que "a Administração e seus agentes têm de atuar na conformidade de princípios éticos. Violá-los implicará violação ao próprio Direito, configurando ilicitude que assujeita a conduta viciada a invalidação, porquanto tal princípio assumiu foros de pauta jurídica, na conformidade do art. 37 da Constituição. Compreendem-se em seu âmbito, como é evidente, os chamados princípios da lealdade e boa fé... Segundo os cânones da lealdade e da boa-fé, a Administração haverá de proceder em relação aos administrados com sinceridade e lhaneza, sendo-lhe interdito qualquer comportamento astucioso, eivado de malícia, produzido de maneira a confundir, dificultar ou minimizar o exercício de direitos por parte dos cidadãos."

Hely Lopes Meirelles ${ }^{29}$ diz que "o agente administrativo deve, necessariamente, distinguir o bem do mal, o honesto do desonesto. E, ao atuar, não poderá desprezar o elemento ético de sua conduta. Assim, não terá que decidir somente entre o legal e o ilegal, o justo e o injusto, o conveniente e o inconveniente, o oportuno e o inoportuno, mas também entre o honesto e o desonesto. Por considerações de Direito e de moral, o ato administrativo não terá que obedecer somente à lei jurídica, mas também à lei ética da própria instituição, porque nem tudo que é legal é honesto, conforme já proclamavam os romanos: 'non omne quod licet honestum est' '.

\footnotetext{
${ }^{28}$ MELLO, Celso Antonio Bandeira de. Curso de Direito Administrativo, São Paulo: Malheiros, $15^{\text {a }}$ ed., p.109

${ }^{29}$ MEIRELES, Hely Lopes. Direito Administrativo Brasileiro, São Paulo: Malheiros, $24^{\mathrm{a}}$ ed., p.83
} 
Assim, visa tal princípio a propositura de uma atuação proba e reta por parte do administrador público apontando para a necessidade de que atue com as melhores condutas. Tal princípio entendido como prescrição de conduta eticamente universalizável de modo satisfatório, num dado contexto histórico, assume lugar nobre no cerne do controle sistemático das relações administrativas ${ }^{30}$.

Seu conteúdo não é predefinido, sendo que o contexto irá indicar a sua aplicabilidade, conforme uma determinada época no tempo e no espaço, considerados os aceites sociais. Entretanto, o fato de se admitir certa elasticidade não significa que não tenha seus contornos sólidos ou que se possa negar sua essência constitutiva.

O ato praticado deve ser verificado pelo móvel do agente, pela sua intenção moral ou imoral que subverta a moldura pretensamente regular de seus atos. Significa que mesmo apresentando contorno de legalidade poderá ser considerado inadequado.

O princípio da moralidade torna obrigatório que o móvel do agente e o objetivo pretendido estejam em harmonia com o dever de bem administrar e que os contornos do ato estejam superpostos à lei, sujeitando-se, porém, à invalidação se resultar de caprichos pessoais do administrador, afastando-se do dever de bem administrar e da consecução do bem comum ${ }^{31}$.

Interessante referência encontra-se em descrição do Código de Ética Profissional do Servidor Público Civil do Poder Executivo Federal. Conforme os itens I e II da Seção I:

Das Regras Deontológicas.

I - A dignidade, o decoro, o zelo, a eficácia e a consciência dos princípios morais são primados maiores que devem nortear o servidor público, seja no exercício de cargo ou função, ou fora dele, já que refletirá o exercício da vocação do próprio poder estatal. Seus atos, comportamentos e atitudes

30 FREITAS, Juarez. O princípio constitucional da moralidade e o novo controle das relações de administração. Revista Interesse Público - IP. Belo Horizonte, n 51, ano 10, p.13-41, set/out e 2008, p.13.

${ }^{31}$ GARCIA, Emerson. A moralidade administrativa e sua densificação. Revista de Direito Constitucional e Internacional. Ano 11, n⿳0 43, p. 110-137, abr/jun 2003, p.122, 
serão direcionados para a preservação da honra e da tradição dos serviços públicos.

II - O servidor público não poderá jamais desprezar o elemento ético de sua conduta. Assim, não terá que decidir somente entre o legal e o ilegal, o justo e o injusto, o conveniente e o inconveniente, o oportuno $e$ o inoportuno, mas principalmente entre o honesto e o desonesto, consoante as regras contidas no art.37 caput e $\$ 4^{\circ}$ da Constituição Federal."

Para exemplificar a moralidade, cite-se que o Supremo Tribunal Federal julgou procedente ação popular para proteção do patrimônio público, tendo decidido que a remuneração de Prefeito, de Vice-Prefeito e de Vereadores deve ser fixada pela Câmara Municipal em cada legislatura para a subsequente, nos termos do art. 29, V da Constituição Federal e que o fato de Vereadores fixarem a sua própria remuneração e ainda para viger na própria legislatura, indica prática de ato inconstitucional lesivo não só ao patrimônio material do Poder Público, como à moralidade administrativa, que constitui patrimônio moral da sociedade, conforme o art. $5^{\circ}$, LXXIII da Carta Magna ${ }^{32}$.

\subsubsection{4 - Publicidade}

Por este princípio, o Poder Público está obrigado a promover a ampla divulgação de seus atos, uma vez que devem ser realizados sob o manto do interesse público, dando, assim, conhecimento à população, em realidade os administrados, sobre sua conduta.

Abarcado pelo princípio da publicidade, o princípio da transparência impõe à Administração Pública o dever de prestar contas perante a sociedade por meio da divulgação de seus atos, permitindo que os cidadãos deles tomem conhecimento e exerçam seu poder de fiscalização, por si mesmos ou pelos órgãos respectivos.

\footnotetext{
${ }^{32}$ RE 206889, Relator: Min. CARLOS VELLOSO, Segunda Turma, julgado em 25/03/1997, DJ 13-06-1997 PP-26718 EMENT VOL-01873-11 PP-02257, Acesso em 27/08/12 in: http://www.stf.jus.br/portal/jurisprudencia/visualizarEmenta.asp?s1=000110288\&base=baseAcordaos
} 
Não se deseja o alardeio ou o falseamento do objeto divulgado, noticiado, mas sim o revelar da atuação estatal, evitando-se a política do segredo, isto é a arcana praxis, no interior da Administração Pública. Significa afirmar que o exercício da atividade administrativa deve ter em vista a defesa do cidadão por meio da transparência dos atos do Poder Público. ${ }^{33}$.

A publicidade dos atos públicos faz despertar o 'status' político dos administrados, bem como alavanca os processos de controle e de cooperação na gestão da coisa pública ${ }^{34}$ estando intimamente ligado com a gestão democrática em si, na medida em que a Administração Pública não administra para ela, mas sim para os cidadãos, detentores da soberania popular, razão pela qual a publicidade não deve se limitar aos aspectos formais, mas sim indicar de forma ampla e efetiva o que acontece no cerne das decisões estatais.

Cabe referir que até a participação dos cidadãos e entidades da sociedade civil podem contribuir para a efetiva eficácia de tal princípio e neste sentido Adilson Dallari $^{35}$ afirma que "Este atributo se liga ao princípio da publicidade, mas vai um pouco além. Não basta que as decisões sejam públicas, pois a democracia participativa exige que se proporcione oportunidade de participação do corpo social no próprio processo de tomada de decisão".

Menciona-se, a título de exemplo, o recebimento de doação de bem móvel feita por empresa privada em favor do Ministério Público e que se incorpora a seu patrimônio, sendo que a divulgação em veículo oficial permite à sociedade que verifique, em qualquer ocasião, se houve comprometimento da atuação da Instituição (se alguma investigação recair na doadora).

Assim, encontra-se publicado no DOE de 27 de agosto de 2012 ato do Procurador Geral de Justiça (Ato $n^{\circ}$ 040/2012- PGJ, de 24 de agosto de 2012) que autoriza o recebimento, em doação, do bem que especifica.

\footnotetext{
${ }^{33}$ CANOTILHO, José Joaquim Gomes. Direito Constitucional. $7^{\mathrm{a}}$ ed. Coimbra: Almedina, 2003, p.1165

${ }^{34}$ LIMA, Raimundo Márcio Ribeiro. Premissas principiológicas e garantísticas indispensáveis a uma regular atuação da administração pública e o silêncio administrativo. Revista da Advocacia Geral da União, Ano X, no 28. Brasilia-DF, abr./jun. 2011. p. 255

${ }^{35}$ DALLARI, Adilson de Abreu. Administração pública no Estado de Direito. Revista Trimestral de Direito Público, 5/40.
} 
O PROCURADOR-GERAL DE JUSTIÇA, no uso de sua competência prevista no item 2, da alínea " $b$ ", do inciso $I X$, do artigo 19, da Lei Complementar n. ${ }^{\circ}$ 734, de 26 de novembro de 1993, Resolve: Artigo 1. ${ }^{\circ}$ Fica o Ministério Público do Estado de São Paulo autorizado a receber, em doação, sem encargos, da empresa Nextel Telecomunicação Ltda., 4 (quatro) aparelhos de radiocomunicação, todos do modelo i296 e da marca Nextel, com os seguintes números de série: 364NND579X, 364NND4SZJ, 364NND4SYW e 364NND5D8X, avaliados em $R \$$ 259,00 (duzentos e cinquenta e nove reais) cada um, perfazendo o valor total de $R \$ 1.036,00$ (mil e trinta e seis reais). Artigo $2 .^{\circ}-$ A Diretoria-Geral adotará as providências de caráter contábil e administrativo necessárias à incorporação patrimonial, devendo os bens ser agregados ao patrimônio do Ministério Público do Estado de São Paulo. Artigo 3. ${ }^{o}$ - Este Ato entrará em vigor na data de sua publicação.

Entretanto, é de se considerar que se por um lado é dever da administração tornar seus atos públicos e agir com transparência, por outro há ressalvas que devem ser observadas, sob perigo de invasão em esferas de outros princípios e direitos.

Neste sentido Odete Medauar $^{36}$ chama a atenção para a questão da mitigação da publicidade e transparência em razão da defesa da preservação da intimidade, privacidade, honra e imagem dos indivíduos: “Outra ressalva a esse direito (informação) $e$ ao princípio da publicidade em geral encontra-se na preservação da intimidade, da vida privada, da honra, da imagem das pessoas, declaradas invioláveis pela Constituição, no inc. X do mesmo artigo $5^{\circ}$ - em tais casos, o sigilo há de predominar sobre a publicidade, para preservação desses direitos, declarados invioláveis. ”.

Claudio Lembo $^{37}$ ensina que um dos grandes dilemas da sociedade contemporânea fundamentada na informação é captar, em cada caso, o que é mais

\footnotetext{
${ }^{36}$ MEDAUAR, Odete. Direito Administrativo Moderno. 10 ${ }^{\mathrm{a}}$. ed. revista e atualizada. São Paulo: Editora Revista dos Tribunais, 2006. p.128/129.

${ }^{37}$ LEMBO, Cláudio. A pessoa: seus direitos. $1^{\text {a }}$ Ed. Barueri - SP. Manole, 2007. P.180,181
} 
relevante: o 'interesse público' ou a 'intimidade pessoal' e indica que se coloca o 'princípio do balanceamento' como fiel da avaliação.

Aponta que o direito à intimidade, consolidado ao longo da evolução dos direitos da pessoa no Ocidente, é, entre os direitos fundamentais aquele que mais sofreu degradação ou contaminação pelo contágio com a tecnologia, mencionando que alhures, os italianos falam em 'dados sensíveis' da personalidade que exigem reserva da privacidade e que a doutrina norte-americana classifica em quatro categorias as agressões contra a intimidade: 'apropriação' (captação de benefícios ou vantagens por ação delituosa, mediante uso indevido do nome ou imagem da pessoa); ‘intrusão’ (ação invasiva do espaço íntimo da pessoa); 'publicidade (disclosure) de fatos privados' (divulgação pública de informações sobre a vida privada da pessoa) e ‘falsa luz aos olhos do público' (exposição de fatos ou atos não verdadeiros, de forma a prejudicar a imagem da pessoa), o que equivale a colocá-la sob um falso facho de luz.

O reconhecimento da importância do tema e do efetivo movimento moderno de ausência de privacidade aos indivíduos leva à necessária conclusão que o ente abstrato que existe para garantir a harmonia social não pode agir no sentido de criar dissonâncias, escudado em um único argumento.

Odete Medauar ${ }^{38}$, ao se referir ao Princípio da preponderância do interesse público sobre o interesse particular ensina: “... Esse clássico princípio (...) vem sendo matizado pela idéia de que à Administração cabe realizar a ponderação dos interesses presentes numa determinada circunstância, para que não ocorra sacrifício 'a priori' de nenhum interesse; o objetivo dessa função está na busca de compatibilidade ou conciliação dos interesses, com a minimização de sacrifícios. O Princípio da proporcionalidade também matiza o sentido absoluto do preceito, pois implica, entre outras decorrências, a busca da providência menos gravosa, na obtenção de um resultado”.

Procura-se o correto termo em que não haja "colisão de direitos" e a ocorrência de invasões de um princípio na esfera de outro pode e deve ser evitada ou

\footnotetext{
${ }^{38}$ MEDAUAR, Odete. Direito Administrativo Moderno. $10^{\mathrm{a}}$. ed. revista e atualizada. São Paulo: Editora
} Revista dos Tribunais, 2006. p.130. 
mesmo afastada, ponderando-se o equilíbrio entre o interesse público e o interesse privado, respeitando-os na integralidade e simultaneamente.

Sobre esse tema Luiz Alberto David Araujo e Vidal Serrano Nunes Júnior ${ }^{39}$ ensinam que em havendo colisão entre direitos fundamentais sua convivência é possível, desde que sejam harmonizados para a consecução do fim desejado: "Os direitos fundamentais não são absolutos. Isso quer dizer que, por vezes, dois direitos fundamentais podem chocar-se, hipótese em que o exercício de um implicará a invasão do âmbito de proteção do outro. É o que, vezes a fio, ocorre entre o direito de informação e o de privacidade (...). Nesses casos, a convivência dos direitos em colisão exige um regime de cedência recíproca."

A solução para os casos em que houver conflito de direitos fundamentais, segundo os autores, é apontada por Canotilho e Vital Moreira ${ }^{40}$ : "No fundo, a problemática da restrição dos direitos fundamentais supõe sempre um 'conflito positivo de normas constitucionais', a saber, entre uma norma consagradora de certo direito fundamental e outra norma consagradora de outro direito ou de diferente interesse constitucional. A regra de solução do conflito é da 'máxima observância' dos direitos fundamentais envolvidos e da sua 'mínima restrição' compativel com a salvaguarda adequada de outro direito fundamental ou outro interesse constitucional em causa.".

Portanto, deve o administrador público não esconder seus atos e ações, porém, na mesma medida preservar o interesse dos administrados, seja divulgando seja preservando a coletividade de determinadas informações.

O tema que envolve tal conflito foi levado ao Poder Judiciário em autos de ação civil pública movida pela Promotoria de Justiça do Patrimônio Público de São Paulo, sem julgamento definitivo, ainda ${ }^{41}$.

\footnotetext{
${ }^{39}$ NUNES Jr. Vidal Serrano; ARAUJO. Luiz Alberto David. Curso de Direito Constitucional. $3^{\text {a }}$. ed. São Paulo: Saraiva, 1999. p.73.

${ }^{40}$ CANOTILHO, José Joaquim Gomes; MOREIRA, Vital. Fundamentos da Constituição. Coimbra, PT: Coimbra Editora, 1991. p.134.

${ }^{41}$ O Processo, (cuja ação foi proposta pelo autor do presente trabalho) recebeu $\mathrm{n}^{\circ}$ 002294910.2010.8.26.0053 e corre perante a $3^{\mathrm{a}}$ Câmara de Direito Público do Tribunal de Justiça do Estado de São Paulo, após apelação do autor e da Prefeitura de São Paulo (parte passiva dos autos).
} 
Para atendimento de tal princípio, a Lei de Diretrizes Orçamentárias (Lei $n^{\circ}$ 12.708 de 17 de agosto de 2012) apresenta, dentre outros, no art. 17 comando que diz que os órgãos e as entidades integrantes dos Orçamentos Fiscal, da Seguridade Social e de Investimento deverão disponibilizar no Sistema Integrado de Administração de Serviços Gerais - SIASG e no Sistema de Gestão de Convênios e Contratos de Repasse - SICONV, no que couber, informações referentes aos contratos e aos convênios ou instrumentos congêneres firmados, com a identificação das respectivas categorias de programação e fontes de recursos quando se tratar de convênios ou instrumentos congêneres, observadas as normas estabelecidas pelo Poder Executivo.

Também no artigo 104 ao mencionar a publicidade sobre Transferências a Entidades Privadas determina que os órgãos dos Poderes e o Ministério Público da União divulgarão e manterão atualizada, na página do órgão concedente na internet, relação das entidades privadas beneficiadas, contendo, pelo menos nome e CNPJ; nome, função e CPF dos dirigentes; área de atuação; endereço da sede; data, objeto, valor e número do convênio ou instrumento congênere; órgão transferidor; valores transferidos e respectivas datas.

\subsubsection{5 - Eficiência}

Inserido como princípio constitucional por conta da Emenda Constitucional $n^{\circ} 19 / 98$, pode se afirmar que existia com previsão infraconstitucional, como se verifica do Decreto Lei n $200 / 67$ nos artigos 13; 25; 26, III e 94, II, III e V.

A palavra eficiência encontra-se relacionada às contingências econômicas e expressa elementos quantitativos diante de otimizações aritméticas muito mais do que com relação a uma determinada expressão jurídica que revele um propósito seguro quanto ao fim normativo a ser alcançado.

Aponta para o uso regular e preciso dos recursos públicos, em especial aqueles financeiros, em face das complexas demandas da sociedade moderna. Implica em reconhecer que dentre várias possibilidades à disposição do administrador público sempre será possível apreciar qual a que melhor se adéqua na relação custo/benefício, desde que respeitada a legalidade. 
Celso Antonio, entretanto, afirma ${ }^{42}$ que : "Quanto ao princípio da eficiência, não há nada a dizer sobre ele. Trata-se, evidentemente, de algo mais do que desejável. Contudo é juridicamente tão fluido e de tão difícil controle ao lume do Direito, que mais parece um simples adorno agregado ao art. 37 ou o extravasamento de uma aspiração dos que buliram o texto. De toda sorte, o fato é que tal princípio não pode ser concebido (entre nós nunca é demais fazer ressalvas óbvias) senão na intimidade do princípio da legalidade, pois jamais uma suposta busca de eficiência justificaria postergação daquele que é o dever administrativo por excelência."

Ainda assim é possível se dizer que o gestor público não pode descurar da qualidade dos bens ou produtos adquiridos ou dos serviços a serem prestados, uma vez que a qualidade não é um enfeite das escolhas, mas sim um valor exigível pelo interesse público. Deve-se prestigiar a melhor escolha diante das respectivas demandas fáticas existentes.

Para ilustrar a questão da eficiência, reporta-se decisão do $\mathrm{STF}^{43}$, quando de julgamento de ação direta de inconstitucionalidade frente aos artigos $7^{\circ}$ a $10^{\circ}$ do Decreto $\mathrm{n}^{\circ}$ 5.820 de 29 de junho de 2006, expedido pelo Presidente da República referente à adoção do sistema brasileiro de televisão digital (SBTVD). Admitiu a Corte a inexistência de violação ao art. $220, \S 5^{\circ}$ e ao art. 223 , ambos da Constituição Federal referindo a diferença entre autorização de uso do espectro de radiofreqüências e concessão do serviço público de radiodifusão de sons e imagens. Assim, a consignação, regulada pela Lei 9.472/97, seria acessória da concessão ou permissão e a norma inscrita no art. $7^{\circ}$ do Decreto 5.820/2006 (e também nos arts. $8^{\circ}$ a 10) cuidaria de autorização de uso do espectro de radiofreqüências, e não de outorga de concessão do serviço público de radiodifusão de sons e imagens.

A decisão menciona que diante da evolução tecnológica, e para a instituição no país da tecnologia digital de transmissão de sons e imagens, sem interrupção da transmissão de sinais analógicos, fez-se imprescindível a consignação temporária de mais um canal às atuais concessionárias do serviço de radiodifusão de sons e imagens e isso

\footnotetext{
${ }^{42}$ BANDEIRA DE MELLO, Celso Antonio. Curso de Direito Administrativo. São Paulo: Malheiros, $24^{\mathrm{a}}$ ed. 2007. P. 117-118.

${ }^{43}$ ADI 3944, Relator Min. AYRES BRITTO, Tribunal Pleno, julgado em 05/08/2010, DJe-185 DIVULG 3009-2010 PUBLIC 01-10-2010 EMENT VOL-02417-01 PP-00024 RTJ VOL-00216- PP-00252 RT v. 100 , n. 903, 2011, p. 106-123 Acesso em 27/08/12 in:

http://www.stf.jus.br/portal/jurisprudencia/visualizarEmenta.asp?s1=000169187\&base=baseAcordaos
} 
para que veiculassem, simultaneamente, a mesma programação nas tecnologias analógica e digital. Tratou-se de um ato do Presidente da República com o objetivo de manter um serviço público adequado, tanto no que se refere à sua atualidade quanto no tocante à sua continuidade e por isso mesmo serviente do princípio constitucional da eficiência no âmbito da Administração Pública ${ }^{44}$.

\subsubsection{6 - Probidade}

Embora não conste de modo expresso no art. 37 'caput' da Constituição Federal, a probidade, assim como a honestidade, a imparcialidade e a lealdade institucional provêm de complexos processos de valoração da legalidade, passando pela moral administrativa, considerada o universo axiológico da ética institucional, no plano jurídico em se movem os operadores ${ }^{45}$. Passa pela compreensão dos deveres de lealdade, honestidade e imparcialidade administrativas.

Tanto é que em atendimento ao princípio da moralidade (consectária da probidade) e na evidente proteção do patrimônio público, é possível se verificar do art. 18 da Lei de Diretrizes Orçamentárias (Lei $n^{\circ} 12.708$ de 17 de agosto de 2012) que não poderão ser destinados, na elaboração dos orçamentos, recursos para atender a despesas com: I - início de construção, ampliação, reforma voluptuária, aquisição, novas locações ou arrendamentos de imóveis residenciais funcionais; II - aquisição, locação ou arrendamento de mobiliário e equipamento para unidades residenciais funcionais; III - aquisição de automóveis de representação; IV - celebração, renovação e prorrogação de contratos de locação e arrendamento de quaisquer veículos para representação pessoal; V - ações de caráter sigiloso; VI - ações que não sejam de competência da União, nos termos da Constituição; VII - clubes e associações de agentes públicos, ou quaisquer outras entidades congêneres; VIII - pagamento, a qualquer título, a agente público da ativa por serviços prestados, inclusive consultoria, assistência técnica ou assemelhados, à conta de quaisquer fontes de recursos; IX - compra de títulos públicos por parte de entidades da administração pública federal indireta; $\mathrm{X}$ - pagamento de diárias e passagens a agente público da ativa por intermédio de convênios ou instrumentos congêneres firmados com entidades de direito

\footnotetext{
${ }^{44}$ Considerando-se que o tipo de serviço público de radiodifusão de sons e imagens faz parte do patrimônio público impróprio diferido (conforme classificação que será estudada mais adiante).

${ }^{45}$ OSÓRIO, Fábio Medina. Teoria da Improbidade Administrativa. São Paulo: RT, 2007. p. 176-177
} 
privado ou com órgãos ou entidades de direito público; XI - concessão, ainda que indireta, de qualquer benefício, vantagem ou parcela de natureza indenizatória a agentes públicos com a finalidade de atender despesas relacionadas a moradia, hospedagem, transporte ou atendimento de despesas com finalidade similar, seja sob a forma de auxílio, ajuda de custo ou qualquer outra denominação; XII - pagamento, a qualquer título, a empresas privadas que tenham em seu quadro societário servidor público da ativa, ou empregado de empresa pública ou de sociedade de economia mista, por serviços prestados, inclusive consultoria, assistência técnica ou assemelhados; e XIII - transferência de recursos a entidades privadas destinados à realização de eventos, no âmbito dos Ministérios do Turismo e da Cultura.

Entretanto, a própria Lei prevê as exceções, sendo que em seus parágrafos (do art. 18) admite que desde que o gasto seja discriminado em categoria de programação específica ou elemento de despesa específico, excluem-se das vedações previstas: I - nos incisos I e II do caput, as destinações para: a) unidades equipadas, essenciais à ação das organizações militares; b) representações diplomáticas no exterior; c) residências funcionais, em Brasília, dos Ministros de Estado, do Supremo Tribunal Federal e dos Tribunais Superiores e dos membros do Poder Legislativo; e d) residências funcionais, em faixa de fronteira, para magistrados da Justiça Federal e membros do Ministério Público da União, quando necessárias à sua segurança no exercício de atividades diretamente relacionadas com o combate ao tráfico e ao contrabando;

Também no inciso III do caput, as aquisições de automóveis de representação para uso: a) do Presidente, Vice-Presidente e dos ex-Presidentes da República; b) dos Membros das Mesas Diretoras da Câmara dos Deputados e do Senado Federal; c) dos Ministros do Supremo Tribunal Federal, dos Tribunais Superiores e dos Presidentes dos Tribunais Regionais e do Tribunal de Justiça do Distrito Federal e dos Territórios; d) dos Ministros de Estado; e) do Procurador-Geral da República; f) dos Comandantes da Marinha, do Exército e da Aeronáutica; g) do Cerimonial do serviço diplomático; e h) das representações diplomáticas no exterior, com recursos oriundos da renda consular;

Outra permissão diz respeito ao inciso V do caput, quando as ações forem realizadas por órgãos ou entidades cuja legislação que as criou estabeleça, entre suas competências, o desenvolvimento de atividades relativas à segurança da sociedade e do 
Estado e que tenham como precondição o sigilo e no inciso VI, as despesas que não sejam de competência da União, relativas: a) ao processo de descentralização dos sistemas de transporte ferroviário de passageiros, urbanos e suburbanos, até o limite dos recursos aprovados pelo Conselho Diretor do Processo de Transferência dos respectivos sistemas; b) ao transporte metroviário de passageiros; c) à construção de vias e obras rodoviárias estaduais destinadas à integração de modais de transporte; d) à malha rodoviária federal, cujo domínio seja descentralizado aos Estados e ao Distrito Federal; e) às ações de segurança pública nos termos do caput do art. 144 da Constituição; e f) à assistência técnica e cooperação financeira, mediante a utilização de recursos oriundos de operações de crédito externas aos Estados, ao Distrito Federal e aos Municípios, para modernização das suas funções de planejamento e administração e aos respectivos Tribunais de Contas, com vistas ao fortalecimento institucional para cumprimento dos dispositivos e atribuições estabelecidas na Lei de Responsabilidade Fiscal.

Ainda no inciso VII do caput, as creches; e as escolas para o atendimento pré-escolar; e no inciso VIII, o pagamento pela prestação de serviços técnicos profissionais especializados por tempo determinado, quando os contratados se encontrem submetidos a regime de trabalho que comporte o exercício de outra atividade e haja declaração do chefe imediato e do dirigente máximo do órgão de origem da inexistência de incompatibilidade de horários e de comprometimento das atividades atribuídas, desde que esteja previsto em legislação específica ou refira-se à realização de pesquisas e estudos de excelência, estes com recursos repassados às organizações sociais, nos termos dos respectivos contratos de gestão ou realizados por professores universitários na situação prevista na alínea " $b$ " do inciso XVI do art. 37 da Constituição, desde que os projetos de pesquisas e os estudos tenham sido devidamente aprovados pelo dirigente máximo do órgão ou da entidade ao qual esteja vinculado o respectivo professor.

Outras exceções apontam para o inciso IX do caput, na compra de títulos públicos para atividades que foram legalmente atribuídas às entidades da administração pública federal indireta; o inciso $\mathrm{X}$ do caput, no pagamento a militares, servidores e empregados pertencentes ao quadro de pessoal do convenente, pertencentes ao quadro de pessoal da administração pública federal, vinculado ao objeto de convênio, quando o órgão for destinatário de repasse financeiro oriundo de outros entes da Federação ou em atividades de pesquisa científica e tecnológica. 
Finalmente no inciso XI do caput, quando houver lei que discrimine o valor ou o critério para sua apuração; em estrita necessidade de serviço, devidamente justificada; e de natureza temporária, caracterizada pelo exercício de mandato ou pelo desempenho de ação específica.

A contratação de serviços de consultoria, inclusive aquela realizada no âmbito de acordos de cooperação técnica com organismos e entidades internacionais, somente será autorizada para execução de atividades que, comprovadamente, não possam ser desempenhadas por servidores ou empregados da administração pública federal, no âmbito do respectivo órgão ou entidade, publicando-se no Diário Oficial da União, além do extrato do contrato, a justificativa e a autorização da contratação, na qual constarão, necessariamente, a identificação do responsável pela execução do contrato, a descrição completa do objeto do contrato, o quantitativo médio de consultores, o custo total e a especificação dos serviços e o prazo de conclusão.

A restrição prevista no inciso VIII do caput não se aplica ao servidor que se encontre em licença sem remuneração para tratar de interesse particular, enquanto que ao disposto nos incisos VIII e XII do caput aplica-se também aos pagamentos à conta de recursos provenientes de convênios, acordos, ajustes ou instrumentos congêneres, firmados com órgãos ou entidades de direito público e a vedação prevista no inciso XIII do caput não se aplica às destinações, no Ministério da Cultura, para realização de eventos culturais tradicionais de caráter público realizados há, no mínimo, cinco anos ininterruptamente, desde que haja prévia e ampla seleção promovida pelo órgão concedente ou pelo ente público convenente.

De qualquer forma, ainda que se excepcionem diversas situações, o comando principal visa atender à moralidade e as exceções também obedecem, isoladamente ao princípio, estando adequados à proteção do patrimônio público.

Entretanto, é fato que a probidade está alçada à condição de princípio constitucional, na medida em que o $\$ 4^{\circ}$ daquele artigo menciona que: "os atos de improbidade administrativa importarão a suspensão dos direitos políticos, a perda da função pública, a indisponibilidade dos bens e o ressarcimento ao erário, na forma e gradação previstas em lei, sem prejuízo da ação penal cabivel”. 
O tema guarda específicos contornos com a censura ética e de valoração de comportamentos indevidos do agente público. Importa, portanto, para o escopo do trabalho breve referência à lei que disciplina tal parágrafo, no que tange à opção do legislador no trato de tal princípio.

\subsubsection{1 - A Lei de Improbidade Administrativa}

Conhecida por Lei de Improbidade Administrativa, a Lei ${ }^{\circ}$ 8137/90 define o ato de improbidade. Temos que três são as modalidades: o enriquecimento ilícito, o dano ao erário e a violação de princípios constitucionais.

Reza o art. $1^{\circ}$ que os atos de improbidade praticados por qualquer agente público, servidor ou não, contra a administração direta, indireta ou fundacional de qualquer dos Poderes da União, dos Estados, do Distrito Federal, dos Municípios, de Território, de empresa incorporada ao patrimônio público ou de entidade para cuja criação ou custeio o erário haja concorrido ou concorra com mais de cinqüienta por cento do patrimônio ou da receita anual, serão punidos na forma da lei.

E no parágrafo único temos que estão também sujeitos às mesmas penalidades os atos de improbidade praticados contra o patrimônio de entidade que receba subvenção, benefício ou incentivo, fiscal ou creditício, de órgão público bem como daquelas para cuja criação ou custeio o erário haja concorrido ou concorra com menos de cinqüenta por cento do patrimônio ou da receita anual, limitando-se, nestes casos, a sanção patrimonial à repercussão do ilícito sobre a contribuição dos cofres públicos.

Define-se o enriquecimento ilícito (Art. $9^{\circ}$ ) como auferir qualquer tipo de vantagem patrimonial indevida em razão do exercício de cargo, mandato, função, emprego ou atividade nas entidades mencionadas no art. $1^{\circ}$. Consta um rol, exemplificativo, diga-se, do que seriam tais condutas.

Porém é de destacar e mencionar as condutas, frente à proteção do patrimônio público. 
Receber, para si ou para outrem, dinheiro, bem móvel ou imóvel, ou qualquer outra vantagem econômica, direta ou indireta, a título de comissão, percentagem, gratificação ou presente de quem tenha interesse, direto ou indireto, que possa ser atingido ou amparado por ação ou omissão decorrente das atribuições do agente público; perceber vantagem econômica, direta ou indireta, para facilitar a aquisição, permuta ou locação de bem móvel ou imóvel, ou a contratação de serviços pelas entidades referidas no art. $1^{\circ}$ por preço superior ao valor de mercado; perceber vantagem econômica, direta ou indireta, para facilitar a alienação, permuta ou locação de bem público ou o fornecimento de serviço por ente estatal por preço inferior ao valor de mercado;

Utilizar, em obra ou serviço particular, veículos, máquinas, equipamentos ou material de qualquer natureza, de propriedade ou à disposição de qualquer das entidades mencionadas no art. $1^{\circ}$, bem como o trabalho de servidores públicos, empregados ou terceiros contratados por tais entidades; receber vantagem econômica de qualquer natureza, direta ou indireta, para tolerar a exploração ou a prática de jogos de azar, de lenocínio, de narcotráfico, de contrabando, de usura ou de qualquer outra atividade ilícita, ou aceitar promessa de tal vantagem; receber vantagem econômica de qualquer natureza, direta ou indireta, para fazer declaração falsa sobre medição ou avaliação em obras públicas ou qualquer outro serviço, ou sobre quantidade, peso, medida, qualidade ou característica de mercadorias ou bens fornecidos a qualquer das entidades mencionadas no art. $1^{\mathrm{o}}$;

Adquirir, para si ou para outrem, no exercício de mandato, cargo, emprego ou função pública, bens de qualquer natureza cujo valor seja desproporcional à evolução do patrimônio ou à renda do agente público; aceitar emprego, comissão ou exercer atividade de consultoria ou assessoramento para pessoa física ou jurídica que tenha interesse suscetível de ser atingido ou amparado por ação ou omissão decorrente das atribuições do agente público, durante a atividade; perceber vantagem econômica para intermediar a liberação ou aplicação de verba pública de qualquer natureza;

Receber vantagem econômica de qualquer natureza, direta ou indiretamente, para omitir ato de ofício, providência ou declaração a que esteja obrigado; incorporar, por qualquer forma, ao seu patrimônio bens, rendas, verbas ou valores integrantes do acervo patrimonial das entidades mencionadas no art. $1^{\circ}$ e ainda usar, em proveito próprio, bens, 
rendas, verbas ou valores integrantes do acervo patrimonial das entidades mencionadas no art. $1^{\circ}$.

Por outro lado, define-se o dano ao erário (Art. 10) como sendo qualquer ação ou omissão, dolosa ou culposa, que enseje perda patrimonial, desvio, apropriação, malbaratamento ou dilapidação dos bens ou haveres daquelas mesmas entidades referidas no art. $1^{\circ}$.

Também consta rol exemplificativo, como segue:

Facilitar ou concorrer por qualquer forma para a incorporação ao patrimônio particular, de pessoa física ou jurídica, de bens, rendas, verbas ou valores integrantes do acervo patrimonial das entidades mencionadas no art. $1^{\circ}$; permitir ou concorrer para que pessoa física ou jurídica privada utilize bens, rendas, verbas ou valores integrantes do acervo patrimonial das entidades mencionadas no art. $1^{\circ}$, sem a observância das formalidades legais ou regulamentares aplicáveis à espécie.

Doar à pessoa física ou jurídica bem como ao ente despersonalizado, ainda que de fins educativos ou assistências, bens, rendas, verbas ou valores do patrimônio de qualquer das entidades mencionadas no art. $1^{\circ}$, sem observância das formalidades legais e regulamentares aplicáveis à espécie; permitir ou facilitar a alienação, permuta ou locação de bem integrante do patrimônio de qualquer das entidades referidas no art. $1^{\circ}$, ou ainda a prestação de serviço por parte delas, por preço inferior ao de mercado.

Permitir ou facilitar a aquisição, permuta ou locação de bem ou serviço por preço superior ao de mercado; realizar operação financeira sem observância das normas legais e regulamentares ou aceitar garantia insuficiente ou inidônea; conceder benefício administrativo ou fiscal sem a observância das formalidades legais ou regulamentares aplicáveis à espécie; frustrar a licitude de processo licitatório ou dispensá-lo indevidamente; ordenar ou permitir a realização de despesas não autorizadas em lei ou regulamento. 
Agir negligentemente na arrecadação de tributo ou renda, bem como no que diz respeito à conservação do patrimônio público; liberar verba pública sem a estrita observância das normas pertinentes ou influir de qualquer forma para a sua aplicação irregular; permitir, facilitar ou concorrer para que terceiro se enriqueça ilicitamente.

Permitir que se utilize, em obra ou serviço particular, veículos, máquinas, equipamentos ou material de qualquer natureza, de propriedade ou à disposição de qualquer das entidades mencionadas no art. $1^{\circ}$, bem como o trabalho de servidor público, empregados ou terceiros contratados por essas entidades; celebrar contrato ou outro instrumento que tenha por objeto a prestação de serviços públicos por meio da gestão associada sem observar as formalidades previstas na lei; celebrar contrato de rateio de consórcio público sem suficiente e prévia dotação orçamentária, ou sem observar as formalidades previstas na lei.

Finalmente, a violação de Princípios da Administração Pública (Art.11) consiste em qualquer ação ou omissão que viole os deveres de honestidade, imparcialidade, legalidade, e lealdade às instituições.

Há ênfase às seguintes condutas, exemplificativas, que transcrevo pelos mesmos motivos acima indicados:

Praticar ato visando fim proibido em lei ou regulamento ou diverso daquele previsto, na regra de competência; retardar ou deixar de praticar, indevidamente, ato de ofício; revelar fato ou circunstância de que tem ciência em razão das atribuições e que deva permanecer em segredo; negar publicidade aos atos oficiais; frustrar a licitude de concurso público; deixar de prestar contas quando esteja obrigado a fazê-lo; revelar ou permitir que chegue ao conhecimento de terceiro, antes da respectiva divulgação oficial, teor de medida política ou econômica capaz de afetar o preço de mercadoria, bem ou serviço.

As penas estão previstas no art. 12, que ao indicá-las, reconhece a independência das instâncias penais, civis e administrativas e admite que possam ser aplicadas de forma isolada ou acumulada, conforme a gravidade do fato, tópico este que sempre foi defendido pela ampla doutrina e somente inserido no texto pela Lei $\mathrm{n}^{\mathbf{0}} 12.120$ de 2009. 
Para o enriquecimento ilícito, cabe a perda dos bens ou valores acrescidos ilicitamente ao patrimônio, ressarcimento integral do dano, quando houver, perda da função pública, suspensão dos direitos políticos de oito a dez anos, pagamento de multa civil de até três vezes o valor do acréscimo patrimonial e proibição de contratar com o Poder Público ou receber benefícios ou incentivos fiscais ou creditícios, direta ou indiretamente, ainda que por intermédio de pessoa jurídica da qual seja sócio majoritário, pelo prazo de dez anos.

Para o dano ao erário o ressarcimento integral do dano, perda dos bens ou valores acrescidos ilicitamente ao patrimônio, se concorrer esta circunstância, perda da função pública, suspensão dos direitos políticos de cinco a oito anos, pagamento de multa civil de até duas vezes o valor do dano e proibição de contratar com o Poder Público ou receber benefícios ou incentivos fiscais ou creditícios, direta ou indiretamente, ainda que por intermédio de pessoa jurídica da qual seja sócio majoritário, pelo prazo de cinco anos.

E para a violação de princípios o ressarcimento integral do dano, se houver, perda da função pública, suspensão dos direitos políticos de três a cinco anos, pagamento de multa civil de até cem vezes o valor da remuneração percebida pelo agente e proibição de contratar com o Poder Público ou receber benefícios ou incentivos fiscais ou creditícios, direta ou indiretamente, ainda que por intermédio de pessoa jurídica da qual seja sócio majoritário, pelo prazo de três anos.

Observa-se menção a ressarcimento de dano mesmo quando a conduta, em tese, a ser punida está afeta a violação de princípios. Isoladamente exigiria reconhecimento de dano, afeto a outro artigo, também, senão não haveria necessidade de previsões distintas. Aparente contradição aconteceria, entretanto, pode-se construir exegese no sentido de que legislador admite, dependendo do caso concreto, que os artigos distintos possam incidir de forma independente e que pode existir situação em que a improbidade decorre da violação dos princípios e o dano, como mera consequência, não seria o ato ímprobo em si, limitando-se a exigência à recomposição quanto a ele.

A aplicação das penas não está vinculada à efetiva ocorrência de dano ao patrimônio público, salvo quanto à pena de ressarcimento ou da aprovação ou rejeição das contas pelo órgão de controle interno ou pelo Tribunal ou Conselho de Contas, embora as 
investigações do Ministério Público por danos ao patrimônio público ou a propositura de ação popular ou de civil pública não dependam, necessariamente do julgamento das contas pelo Tribunal de Contas e isto porque o Ministério Público e o Poder Judiciário não estão vinculados àquelas decisões. $\mathrm{O}$ tema será aprofundado mais adiante.

A jurisprudência é extensa no tema, porém a título de exemplo menciona-se decisão do Superior Tribunal de Justiça ${ }^{46}$ em autos de ação civil pública proposta pelo Ministério Público do Estado de Santa Catarina em face da ex-prefeita do Município de Bocaina do Sul, quando se imputou ato de improbidade administrativa, decorrente de irregularidades em procedimentos licitatórios. A conduta reconhecida como ímproba se constituiu na aquisição de um caminhão de carga pela prefeitura, no valor de $\mathrm{R} \$ 66.000,00$, que, contudo, estava alienado fiduciariamente à empresa 'OMNI Local S/A' e, ainda, penhorado pelo Banco do Brasil, impossibilitando o respectivo registro em nome do município.

Na medida em que o ato de improbidade administrativa previsto no art. 10 da Lei $n^{\circ} 8.429 / 92$ exige a comprovação do dano ao erário e a existência de dolo ou culpa do agente ${ }^{47}$ o acórdão recorrido considerou evidenciada a atuação negligente da gestora pública, ao autorizar o pagamento de um bem sem avaliar a existência de gravames que impossibilitaram a transferência da propriedade. Nesse contexto, tem-se que a prefeita municipal descumpriu com o dever de zelo com a coisa pública, pois efetuou a despesa sem tomar a mínima cautela de aferir que o automóvel estava alienado fiduciariamente, bem como penhorado à instituição financeira. Por outro lado, o dano ao erário está caracterizado pela impossibilidade de se transferir o bem para o patrimônio municipal. Assim, foi reconhecida a prática do ato de improbidade administrativa.

Finalmente, pode-se afirmar no tema dos princípios que regem a atuação do administrador público que distintos parâmetros ainda podem ser encontrados, dentre eles outros princípios implícitos ao regime jurídico administrativo, como a supremacia do interesse público sobre o particular, a autotutela administrativa, a distribuição equitativa

\footnotetext{
${ }^{46}$ REsp 1151884/SC, Rel. Ministro CASTRO MEIRA, SEGUNDA TURMA, julgado em 15/05/2012, DJe 25/05/2012 - Acesso em 27/08/12, in: http://www.sti.jus.br/SCON/jurisprudencia/doc.jsp?livre=improbidade+e+patrim $\% \mathrm{~F} 4$ nio $+\mathrm{p} \% \mathrm{FAblico} \& \& \mathrm{~b}=$ ACOR\&p=true \& $\mathrm{t}=\& \mathrm{l}=10 \& \mathrm{i}=6 \#$.

${ }^{47}$ Precedente: EREsp 479.812/SP, Rel. Min. Teori Albino Zavascki, DJe 27.09.10
} 
dos ônus e encargos públicos, a razoabilidade, o direito de petição, de ampla defesa e do contraditório, por exemplo, porém todos vinculados àqueles principais trazidos pela Constituição Federal.

2.2 - A Administração Pública.

Como já foi mencionado no início do trabalho, o Estado se constituiu a partir de evolução da necessidade de se estabelecer um mecanismo de harmonização da vida em sociedade.

A administração pública pode ser considerada como o instrumento do Estado para a consecução daquele objetivo, comportando-se de modo complexo diante da própria complexidade do grupo a que pretende servir.

A seguir, será visto como a doutrina conceitua a administração pública e ainda como pode ser dividida.

\subsection{1 - Conceituação.}

Administração, como conceito, para Maria Sylvia Zanela Di Pietro ${ }^{48}$ é a atividade daquele que não é senhor absoluto. Indica que tanto na administração privada como na pública há uma atividade dependente de uma vontade externa, individual ou coletiva, vinculada ao princípio da finalidade; vale dizer que toda atividade de administração deve ser útil ao interesse que o administrador deve satisfazer e no caso da Administração Pública, a vontade decorre da lei que fixa a finalidade a ser perseguida pelo administrador.

Quando se refere a critérios para a expressão "administração pública" aponta que, basicamente, seriam dois os sentidos mais utilizados: o primeiro um sentido subjetivo, formal ou orgânico que designaria os entes que exercem a atividade administrativa; compreendendo pessoas jurídicas, órgãos e agentes públicos incumbidos de exercer uma das funções em que se triparte a atividade estatal: a função administrativa; o

${ }^{48}$ DI PIETRO, Maria Sylvia Zanella. Direito Administrativo, $23^{\mathrm{a}}$ Ed. São Paulo: Atlas, 2010, p. 48-49. 
segundo, um sentido objetivo, material ou funcional, quando designando a natureza da atividade exercida pelos referidos entes; nesse sentido, a administração pública é a própria função administrativa que incumbe, predominantemente ao Poder Executivo.

Menciona a existência de outra distinção que alguns autores costumam fazer, a partir da ideia de que administrar compreende planejar e executar, vale dizer: em sentido amplo, a Administração Pública, subjetivamente considerada, compreende tanto os órgãos governamentais, supremos, constitucionais (Governo), aos quais incumbe traçar os planos de ação, dirigir, comandar, como também os órgãos administrativos, subordinados, dependentes (Administração Pública, em sentido estrito), aos quais incumbe executar os planos governamentais. Ainda em sentido amplo, porém objetivamente considerada, a administração pública compreende a função política, que traça as diretrizes governamentais e a função administrativa, que as executa. Já em sentido estrito, a Administração Pública compreende, sob o aspecto subjetivo, apenas os órgãos administrativos e, sob o aspecto objetivo, apenas a função administrativa, excluídos, no primeiro caso, os órgãos governamentais e, no segundo, a função política ${ }^{49}$.

Já Diógenes Gasparini ${ }^{50}$ escreve que a administração encerra a ideia geral de relação hierárquica e de um comportamento eminentemente dinâmico e que tem, por outro lado, um conteúdo ora vulgar, ora técnico. Indica em letras minúsculas a administração pública como atividade administrativa ou função administrativa e em letras maiúsculas a Administração Pública como Estado.

Destaca critérios negativistas, formal e material, sendo que com base no primeiro, o negativista, administração pública é toda atividade do Estado que não seja legislativa e judiciária. Tal critério parece encontrar sua justificativa nos Estados primitivos, onde o chefe detinha todos os poderes em suas mãos e a ele incumbia legislar, administrar e julgar e se retiradas as atividades de julgar e legislar, restava-lhe a de administrar. Apesar disso, reconhece que não satisfaz. Defende que a definição deve ser positiva: deve dizer o que uma coisa é, e não o que uma coisa não é. Ademais, os vocábulos "julgar" e "legislar" seriam equivocados, porque tendo mais de um sentido dificultam a compreensão do conceito formulado.

\footnotetext{
${ }^{49}$ DI PIETRO, Maria Sylvia Zanella. Direito Administrativo, $23^{a}$ Ed. São Paulo: Atlas, 2010, p.49

${ }^{50}$ GASPARINI, Diógenes, Direito Administrativo, ${ }^{\mathrm{a}}$ Ed. São Paulo: Saraiva, 2003, p. 41-42.
} 
Pelo critério formal, também denominado orgânico ou subjetivo, a expressão indicaria um complexo de órgãos responsáveis por funções administrativas. De acordo com o material, também chamado de objetivo, é um complexo de atividades concretas e imediatas desempenhadas pelo Estado sob os termos e condições da lei, visando o atendimento das necessidades coletivas. Pelo critério formal, é sinônimo de Estado (Administração Pública); pelo material, equivale a atividade administrativa (administração pública). Com esses dois sentidos é que a Constituição Federal usa, no art. 37, a locução 'Administração Pública'.

Para Hely Lopes Meirelles " “Administração Pública”, em sentido formal, é o conjunto de órgãos instituídos para consecução dos objetivos do Governo; em sentido material, é o conjunto das funções necessárias aos serviços públicos em geral; em acepção operacional, é o desempenho perene e sistemático, legal e técnico, dos serviços próprios do Estado ou por ele assumidos em benefício da coletividade. Numa visão global, a Administração é, pois, todo o aparelhamento do Estado preordenado à realização de seus serviços, visando à satisfação das necessidades coletivas.

Edmir Netto de Araújo ${ }^{52}$ escreve que a palavra 'administração' é um vocábulo análogo (mesma grafia, diversos significados, mas inter-relacionados), com vários sentidos: conjunto de órgãos administrativos, atividade de gerir interesses públicos ou privados, disciplina de certas atividades etc.

Indica que a administração privada (de empresas, sociedades etc.) é a gerência de bens ou interesses privados ou particulares enquanto que quando os fins se referem ao Estado, o termo cunhado é 'administração pública'. Esta pode ser sinônimo de "Administração", grafada com "A" maiúsculo (significando máquina administrativa do Estado, seus órgãos e entidades) ou ainda "administração" com "a" minúsculo (significando atividade de administrar, atividades administrativas).

${ }^{51}$ MEIRELLES, Hely Lopes, Direito Administrativo Brasileiro, 34 ${ }^{\text {a }}$ Ed. São Paulo: Melhoramentos, 2008, pp. 65 e 66.

${ }_{2}^{2}$ ARAÚJO, Edmir Netto de, Curso de Direito Administrativo, $5^{\text {a }}$ Ed. São Paulo: Saraiva, 2010, p.149-150. 
Lembra que muitas vezes o sentido da palavra 'administrar' é o mesmo que 'governar', razão pela qual "Administração" e "Governo" em várias ocasiões se confundem, em que pese materialmente "Governo" se constituir no conjunto de funções estatais básicas e "Administração" ser o conjunto de funções/atribuições necessárias aos serviços públicos, a serem desempenhadas por órgãos ou entidades do Estado.

Portanto, pode-se dizer que a administração pública, seja no quesito abstrato - ou seja, se referida como Governo - seja no quesito concreto - vale dizer, o aparelhamento do Estado para a consecução dos objetivos de atender às necessidades da sociedade - coincide no tema da fiscalização patrimonial, se considerada a proposta anteriormente formulada. Isto é, a fiscalização acontecerá tanto na abstrata como na concreta.

Tem-se que para os objetivos traçados em determinado governo há necessidade de se valer da estrutura patrimonial dos entes que integram ou não tal governo, tanto para o funcionamento da própria administração quando voltada para sí mesma, como para a consecução dos objetivos dirigidos à sociedade (como será visto quando da classificação do patrimônio público).

Embora se reconheça que o Poder Executivo detenha a grande parte das ações voltadas para administrar o Governo propriamente dito e aquelas com escopo de realizar as ações sociais, não se pode descartar o fato de que o Poder Legislativo e o Judiciário, assim como o Ministério Público e o Tribunal de Contas exercem funções administrativas tanto na gerência de seu patrimônio e em seu funcionamento orgânico como em ações voltadas para terceiros (em especial no controle do 'poder pelo poder').

Assim, quando se pensa em fiscalização patrimonial da administração pública se pensa em todos eles e não somente no Poder Executivo, que mesmo sendo preponderante - como se observa tanto das classificações doutrinárias, como na referência da administração indireta e pela especial qualidade de prestador se serviço público - não é excludente dos demais. 
2.2.2 - Descentralização administrativa.

Há distintos modelos de descentralização do Estado, sendo que a administrativa é a que acontece "quando as atribuições que os entes descentralizados exercem só têm o valor jurídico que lhes empresta o ente central; as suas atribuições não decorrem, com força própria, da Constituição, mas do poder central. É o tipo de descentralização própria dos Estados unitários, em que há um centro único de poder, do qual se destacam, com relação de subordinação, os poderes das pessoas jurídicas locais.

\section{(...)}

Os vocábulos autonomia e administração expressam bem a distinção. Autonomia, de autós (próprio) e nómos (lei) significa o poder de editar as próprias leis, sem subordinação a outras normas que não as da própria Constituição; nesse sentido, só existe autonomia onde haja descentralização política. Autoadministração dá ideia de capacidade de gerir os próprios negócios, mas com subordinação a leis postas pelo ente central; é o que ocorre na descentralização administrativa ",53.

No sistema brasileiro, a descentralização foi regulada pelo Decreto-Lei 200/67, ocorrendo a diferenciação entre a Administração Direta e a Indireta.

Há referência sobre a imprecisão da lei neste tema e neste sentido Maria Sylvia traça histórico, como segue ${ }^{54}$.

O artigo $4^{\circ}$. do Decreto-lei $n^{\circ}$. 200/67 divide a Administração Pública em Direta e Indireta. A administração direta compreende os serviços integrados na estrutura administrativa da Presidência da República e na dos Ministérios. A administração indireta abrangia, na redação original, as autarquias, empresas públicas e sociedades de economia mista, equiparando as fundações às empresas públicas.

O Decreto-lei $n^{\circ} .900$, de 29-9-69, no artigo $3^{\circ}$ expressamente declarou que as fundações instituídas por lei federal não integravam a administração indireta, mas se subordinavam à supervisão ministerial, desde que recebessem subvenções ou transferências à conta do orçamento da União.

\footnotetext{
${ }^{53}$ DI PIETRO, Maria Sylvia Zanella. Direito Administrativo, $23^{\text {a }}$ Ed. São Paulo: Atlas, 2010, p.421

${ }^{54}$ DI PIETRO, Maria Sylvia Zanella. Direito Administrativo, $23^{\text {a }}$ Ed. São Paulo: Atlas, 2010, p. 422
} 
Posteriormente, o Decreto-lei $n^{\circ}$. 2.299, de 21-11-86, incluiu as fundações federais entre os órgãos da administração indireta, mas apenas para fins de sujeição às normas de fiscalização, controle e gestão financeira e para fins de inclusão de seus cargos, empregos e funções no Plano de Classificação de Cargos estabelecido para a administração direta; apenas excluiu as fundações universitárias e as destinadas à pesquisa, ao ensino e às atividades culturais.

Finalmente, a Lei $n^{\circ}$. 7.596, de 10-4-87, deu nova redação ao artigo $4^{\circ}$. do Decreto-lei no ${ }^{\circ}$ 200/67, nele incluindo as "fundações públicas". De modo que, hoje são entidades da administração indireta, na órbita federal, segundo esse decreto-lei, as autarquias, empresas públicas, sociedades de economia mista e fundações públicas.

O Decreto-lei $n^{\circ}$. 200/67 tem sido objeto de crítica, nessa parte, por não abranger todas as entidades da administração indireta e por incluir, entre elas, algumas que não são. Com efeito, se era intenção do legislador mencionar, com a expressão "administração indireta", as entidades que prestam serviços públicos descentralizados, ele o fez de maneira imperfeita; primeiro, porque não mencionou as entidades que são concessionárias e permissionárias de serviços públicos (descentralização por colaboração) e que exercem administração indireta ou descentralizada; segundo, porque só considerou como empresas públicas e sociedades de economia mista as que exercem atividade econômica, as quais não são entidades descentralizadas.

Isto porque só existe descentralização quando o poder público destaca um serviço público que lhe é próprio para transferi-lo a outra entidade, com personalidade jurídica própria; ninguém pode delegar uma atribuição que não lhe pertence.

Ocorre que a atuação do Estado não se limita aos serviços públicos; ele às vezes sai da órbita de ação que lhe é própria e vai atuar no âmbito de atividade reservada essencialmente à iniciativa privada; trata-se da atividade de intervenção, que compreende, além da regulamentação e fiscalização da atividade econômica de natureza privada (intervenção indireta), também atuação direta no domínio econômico, o que se dá por meio de empresas estatais (intervenção direta). 
Nesse caso, não se trata de atividade assumida pelo Estado como serviço público; é atividade tipicamente privada que o Estado exerce em regime de monopólio (nos casos indicados no art. 177 da Constituição) ou em regime de competição com a iniciativa privada, conforme o determine o interesse público ou razões de segurança (art. 173). O Estado exerce essa atividade a título de intervenção no domínio econômico, conservando a natureza da atividade como tipicamente privada; por isso mesmo, ele se submete às normas de direito privado que não forem expressamente derrogadas pela Constituição.

Não se pode, pois, tecnicamente, considerar essas empresas que exercem atividade econômica como entidades da administração indireta; somente se pode considerar corretos os conceitos de empresa pública e sociedade de economia mista, contidos no artigo $5^{\circ}$. do Decreto-lei $n^{\circ}$. 200/67, se se considerar a expressão "atividade econômica" em sentido amplo, abrangendo a de natureza privada (exercida a título de intervenção no domínio econômico) e a de natureza pública (assumida pelo Estado como serviço público, comercial ou industrial, como, por exemplo, o de transportes, de navegação aérea, de distribuição de gás).

Com essa abrangência ampla dada à expressão "atividade econômica", usada no artigo $5^{\circ}$ do Decreto-lei $n^{\circ}$. 200/67, fica superada a deficiência conceitual de empresa pública e sociedade de economia mista e chega-se a uma conclusão quanto ao sentido em que o legislador empregou a expressão administração indireta naquele dispositivo.

Assim, Maria Sylvia finaliza a ideia ao procurar entender a intenção do legislador indicando que este “... não se referiu à administração pública como atividade (sentido objetivo), mas como sujeito (sentido subjetivo). Desse modo, administração indireta, no artigo $4^{o}$. do Decreto-lei $n^{o}$. 200, significa o conjunto de pessoas jurídicas, de direito público ou privado, criadas por lei, para o desempenho de atividades assumidas pelo Estado, como serviços públicos ou a título de intervenção no domínio econômico „55.

${ }^{55}$ DI PIETRO, Maria Sylvia Zanella. Direito Administrativo, $23^{\mathrm{a}}$ Ed. São Paulo: Atlas, 2010, p. 422 
Hely Lopes Meirelles ${ }^{56}$ considera que a "Administração Direta é o conjunto dos órgãos integrados na estrutura administrativa da União e a Administração Indireta é o conjunto dos entes (personalizados) que, vinculados a um Ministério, prestam serviços públicos ou de interesse público. Sob o aspecto funcional ou operacional, administração pública direta é a efetivada imediatamente pela União, através de seus órgãos próprios, $e$ indireta é a realizada mediatamente, por meio dos entes a ela vinculados".

Já Celso Antônio Bandeira de Mello ${ }^{57}$, questionando também o conceito formulado no Decreto-Lei 200/67, informa que a Administração Indireta deveria, em tese, coincidir com a ideia de descentralização, o que não ocorreu.

Para ele estamos diante da atividade administrativa descentralizada “(...) quando é exercida, em uma das formas mencionadas, por pessoa ou pessoas distintas do Estado. Diz-se que a atividade administrativa é centralizada quando é exercida pelo próprio Estado, ou seja, pelo conjunto orgânico que lhe compõe a intimidade. Na centralização o Estado atua diretamente por meio dos seus órgãos, isto é, das unidades que são simples repartições interiores de sua pessoa e que por isto dele não se distinguem. Consistem, portanto, em meras distribuições internas de plexos de competência, ou seja, em "desconcentrações" administrativas. Na descentralização o Estado atua indiretamente, pois o faz através de outras pessoas, seres juridicamente distintos dele, ainda quando sejam criaturas suas e por isto mesmo se constituam, (...) em parcelas personalizadas da totalidade do aparelho administrativo estatal".

Segue a mesma linha Diógenes Gasparini ${ }^{58}$., quando afirma que “ $A$ prestação dos serviços públicos é descentralizada na medida em que a atividade administrativa (titularidade e execução) ou a sua mera execução é atribuída a outra entidade, distinta da Administração Pública, para que a realize. Desloca-se a atividade, ou tão-só o seu exercício, da Administração Pública central para outra pessoa jurídica, esta privada, pública ou governamental”.

\footnotetext{
${ }^{56}$ MEIRELLES, Hely Lopes, Direito Administrativo Brasileiro, 34 a Ed. São Paulo: Melhoramentos, 2008,p. 747-748

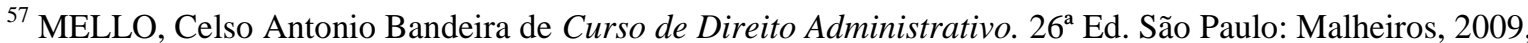
p.149-150.

${ }^{58}$ GASPARINI, Diógenes. Direito Administrativo. $8^{\text {a }}$ Ed. São Paulo: Saraiva, 2003. p. 284-285.
} 
Indica que "o serviço vai da Administração Pública, sua titular, ao administrado, seu beneficiário último, através de uma interposta pessoa jurídica. esta privada, pública ou governamental, que o executa e explora. Da descentralização também pode participar uma pessoa física. Ademais, para se ter configurada essa forma de prestação de serviço público, exige-se que: I - a atividade descentralizada seja administrativa, isto é, serviço público; II - a transferência recaia sobre a titularidade e a execução da atividade ou somente sobre a execução."

Aponta que em cada esfera de governo (federal, estadual, distrital e municipal) podem ser encontradas entidades públicas (autarquias e fundações públicas), governamentais (sociedades de economia mista. empresas públicas e fundações privadas) e privadas (empresas mercantis e industriais), atuando como autorizatárias, permissionárias e concessionárias de serviços públicos. Se as entidades governamentais forem exploradoras de atividade econômica nos moldes do art. 173 da Constituição Federal ${ }^{59}$ elas não integram a Administração Pública indireta e que à vista disso a descentralização administrativa pode ocorrer de duas formas:

A primeira seria a transferência da titularidade e da execução do serviço público da Administração Pública competente para uma pessoa jurídica de direito público, especialmente criada pelo Estado para esse fim, como são a autarquia e a fundação pública. Estas o desempenhariam em nome próprio, executando-o por sua conta e risco, mas sob controle da Administração Pública, a qual. nessa hipótese, desfaz-se da titularidade e da execução do serviço.

\footnotetext{
${ }^{59}$ Art. 173. Ressalvados os casos previstos nesta Constituição, a exploração direta de atividade econômica pelo Estado só será permitida quando necessária aos imperativos da segurança nacional ou a relevante interesse coletivo, conforme definidos em lei. $\S 1^{\circ} \mathrm{A}$ lei estabelecerá o estatuto jurídico da empresa pública, da sociedade de economia mista e de suas subsidiárias que explorem atividade econômica de produção ou comercialização de bens ou de prestação de serviços, dispondo sobre: I - sua função social e formas de fiscalização pelo Estado e pela sociedade; II - a sujeição ao regime jurídico próprio das empresas privadas, inclusive quanto aos direitos e obrigações civis, comerciais, trabalhistas e tributários; III - licitação e contratação de obras, serviços, compras e alienações, observados os princípios da administração pública; IV a constituição e o funcionamento dos conselhos de administração e fiscal, com a participação de acionistas minoritários; V - os mandatos, a avaliação de desempenho e a responsabilidade dos administradores. § $2^{\circ}$ As empresas públicas e as sociedades de economia mista não poderão gozar de privilégios fiscais não extensivos às do setor privado. $\S 3^{\circ}$ - A lei regulamentará as relações da empresa pública com o Estado e a sociedade. $\S 4^{\circ}$ - A lei reprimirá o abuso do poder econômico que vise à dominação dos mercados, à eliminação da concorrência e ao aumento arbitrário dos lucros. § $5^{\circ}$ - A lei, sem prejuízo da responsabilidade individual dos dirigentes da pessoa jurídica, estabelecerá a responsabilidade desta, sujeitando-a às punições compatíveis com sua natureza, nos atos praticados contra a ordem econômica e financeira e contra a economia popular.
} 
A segunda seria o trespasse do simples desempenho ou da mera execução do serviço público da Administração Pública competente para uma pessoa jurídica de direito privado, criada por particular (sociedade civil, comercial. industrial), que assumiria a posição de concessionária ou permissionária; ou instituída pelo Estado (empresa pública, sociedade de economia mista), que assumiria a posição de delegatária.”.

Em realidade, tanto as pessoas jurídicas criadas pelos particulares como as instituídas pela Administração Pública desempenhariam o serviço público, cuja execução lhes foi transferida, em nome próprio e por sua conta e risco, sendo que em tais casos a Administração Pública desfaz-se da execução, mas não da titularidade do serviço.

Eurípedes de Carvalho Pimenta ${ }^{60}$ escreve que "A necessidade de descongestionamento dos serviços públicos que inspira o desenvolvimento das várias modalidades de descentralização (orgânica, política, por colaboração), somada à necessidade que tem o Estado de intervir positivamente na ordem econômica e social, inclusive explorando atividades econômicas, determinaram o surgimento de outros procedimentos de atuação do Poder Público, diretamente inspirados pelos eficientes modelos do Direito Privado”.

Vejamos as entidades individualizadamente:

2.2.2.1 - Autarquias.

O Decreto-lei $n^{\circ}$ 200/1967 conceitua as autarquias como sendo serviço autônomo, criado por lei, com personalidade jurídica, patrimônio e receita próprios, para executar atividades típicas da Administração Pública, que requeiram, para seu melhor funcionamento, gestão administrativa e financeira descentralizada ${ }^{61}$.

Celso Antônio Bandeira de Melo ${ }^{62}$ critica tal definição e, num primeiro momento, define essas entidades como "pessoas jurídicas de Direito Público de

\footnotetext{
${ }^{60}$ PIMENTA, Eurípedes Carvalho. As empresas públicas e os crimes contra a administração pública. In Revista da Procuradoria Geral do Estado, no 10. 1977, p.305.

${ }^{61}$ Art. $5^{\text {a }}$, inciso I do Decreto.-lei 200/1967.

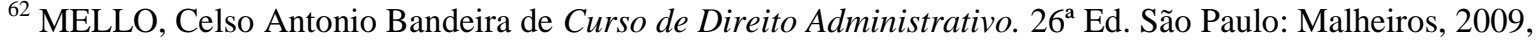
p. 160-161: "Como definição, o enunciado normativo não vale nada. Sequer permite ao intérprete identificar
} 
capacidade exclusivamente administrativa". Diz que a doutrina e a jurisprudência jamais hesitaram em reconhecer o caráter de entidade autárquica às pessoas meramente administrativas revestidas de personalidade de Direito Público e que sendo, como são, pessoas jurídicas, as autarquias gozam de liberdade administrativa nos limites da lei que as criou; não são subordinadas a órgão algum do Estado, mas apenas controladas.

Refere também que se constituindo em centros subjetivados de direitos e obrigações distintos do Estado, seus assuntos são assuntos próprios; seus negócios, negócios próprios; seus recursos, não importa se oriundos de trespasse estatal ou hauridos como produto da atividade que lhes seja afeta, configuram recursos e patrimônio próprios, de tal sorte que desfrutam de "autonomia" financeira, tanto como administrativa; ou seja, suas gestões administrativa e financeira necessariamente são de suas próprias alçadas logo, descentralizadas.

Afirma que sempre se entendeu que as autarquias, por serem pessoas, embora intraestatais, são centros subjetivados de direitos e obrigações distintos do Estado e que na mesma linha, e pelos mesmos fundamentos, doutrina e jurisprudência sempre consideraram, outrossim, que quaisquer pleitos administrativos ou judiciais, decorrentes de atos que lhes fossem imputáveis, perante elas mesmas ou contra elas teriam de ser propostos - e não contra o Estado. Disto se segue igualmente que perante terceiros as autarquias são responsáveis pelos próprios comportamentos. A responsabilidade do Estado, em relação a eles, é apenas subsidiária "63.

Maria Sylvia ${ }^{64}$ analisa a etimologia da palavra, de utilização originária italiana para ponderar que: “(...) o termo autarquia surgiu com significado um pouco diverso daquele empregado no direito brasileiro, pois designava as formas de

quando a figura legalmente instaurada tem ou não natureza autárquica, pois deixou de fazer menção ao único traço que interessaria referir: a personalidade de Direito Público. Exatamente por serem pessoas de Direito Público é que as autarquias podem ser titulares de interesses públicos, ao contrário de empresas públicas e sociedades de economia mista, as quais, sendo pessoas de Direito Privado, podem apenas receber qualificação para o exercício de atividades públicas; não, porém, para titularizar as atividades públicas. Além disto, uma vez que lei crie uma dada entidade autárquica, isto é, uma pessoa de Direito Público dotada de capacidade exclusivamente administrativa, o só fato de fazê-lo já implica, de per si, que a atividade que lhe seja cometida passe, ipso facto, a ser qualificada como típica da Administração Pública, e como tal terá de ser havida.".

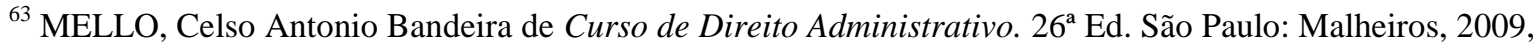
p. 161.

${ }^{64}$ DI PIETRO, Maria Sylvia Zanella. Direito Administrativo, $23^{\mathrm{a}}$ Ed. São Paulo: Atlas, 2010, p.428 
descentralização territorial, próprias dos Estados unitários. Foi mais pelo trabalho de doutrinadores italianos, como Guido Zanobini e Renato Alessi, que se desenvolveu o conceito de autarquia como entidade da administração indireta (descentralização administrativa por serviço), que exerce serviço determinado, com as mesmas características e os mesmos efeitos da atividade administrativa do Estado”.

Conceitua da seguinte forma: “(...), pode-se conceituar a autarquia como a pessoa jurídica de direito público, criada por lei, com capacidade de autoadministração, para o desempenho de serviço público descentralizado, mediante controle administrativo exercido nos limites da lei" ${ }^{, 65}$.

Importa reconhecer que as autarquias são criadas e extintas por lei específica, sendo dotadas de patrimônio e receitas próprias. Devem sofrer controle ou tutela da administração que as criou (dever e não faculdade), sendo, portanto, de atribuição do órgão central que as vincula o recebimento de informações (constantes de relatórios, balanços, balancetes etc.) financeiras, contábeis, patrimoniais e outras. Assim, se faz possível o acompanhamento da atividade da entidade e da correta execução de seu orçamento, sendo que pode até mesmo sofrer intervenção em caso de interesse público (art. 26 do Decreto-lei 200/67).

Também incide o controle (contábil, financeiro, orçamentário e patrimonial) por parte do Tribunal de Contas (arts. 70, 71 e 75 da Constituição Federal) e pelo Poder Legislativo (art. 49, X da Constituição Federal), além da possibilidade de ação popular intentada por qualquer cidadão interessado ou ainda da provocação do Ministério Público para verificação de ato de improbidade administrativa.

Assim como todas as entidades da administração direta e indireta, devem obediência aos princípios insculpidos no art.37 da Constituição Federal, portanto é exigido que se submetam à licitação nos relacionamentos de negócios com terceiros e à promoção de concurso público para ingresso em seus quadros de pessoal (cujo regime jurídico será o estatutário). Da mesma forma incidem as exigências da Lei Federal 4.320/1964 no que

${ }^{65}$ DI PIETRO, Maria Sylvia Zanella. Direito Administrativo, $23^{\text {a }}$ Ed. São Paulo: Atlas, 2010, p.430 
tange ao controle de execução orçamentária e ainda as disposições da Lei de Responsabilidade Fiscal (Lei no 8.429/1992).

Importa indicar que os Conselhos de Fiscalização Profissional são considerados autarquias federais em regime especial (vale dizer, em que são assegurados determinados privilégios não extensivos às autarquias comuns e englobam os Conselhos Federais e Regionais voltados para a fiscalização das atividades profissionais regulamentadas $)^{66}$. São, portanto, entidades de direito público, o que se evidencia diante da impossibilidade de delegação a entidade privada de atividade típica de Estado como poder de tributar, fiscalizar e punir ${ }^{67}$.

Mencione-se a decisão 467/1998 do Plenário do Tribunal de Contas da União (documento $\mathrm{n}^{\mathrm{o}}$ DC-0467-29/98-P) ${ }^{68}$ em que houve reclamação protocolada indicando irregularidades no Conselho de Odontologia do Estado de São Paulo, diante da suspeita de procedimentos contábeis irregulares, inobservância da legislação em licitação para compra de material e para aquisição de passagem aérea, e também realização de despesa sem comprovação em festividades, além de aplicações financeiras em Bancos não oficiais, além de autoconcessão de diárias. A Corte de Contas decidiu pela improcedência da reclamação apontando que as contas daquela entidade referentes ao ano de 1995 já haviam sido analisadas no TC-700.226/96-6 e consideradas regulares. Depreende-se que a houve fiscalização regular do TCU frente àquele Conselho Profissional, embora não seja unânime a tese.

Isto porque, conforme decisão ${ }^{69}$ do Superior Tribunal de Justiça em Embargos de Divergência no Recurso Especial n 503.252 - SC (2003/0151664-0), tendo relatoria do Ministro Castro Meira (julgamento de 25 de agosto de 2004), a Ordem dos Advogados do Brasil não se confunde com as demais corporações incumbidas do exercício profissional.

\footnotetext{
${ }^{66}$ GOMES, Émerson Cesar da Silva, comentário no item 107.4 in CONTI, José Mauricio (coord). Orçamentos Públicos. A Lei $n^{o}$ 4.320/1964 comentada. São Paulo: RT, 2010, p. 373.

${ }^{67}$ Conforme STF na ADI $\mathrm{n}^{\mathrm{o}} 1.717$ que reconheceu a inconstitucionalidade do art. 58 e parágrafos da Lei $\mathrm{n}^{\mathrm{o}}$ 9.649/98 e declarou que os serviços de fiscalização de profissões regulamentadas constitui atividade típica de Estado.

${ }^{68} \mathrm{http}: / /$ contas.tcu.gov.br/pt/MostraDocumento?qn=5. Acesso em 24/08/12

${ }^{69} \mathrm{http://www.stj.gov.br/SCON/jurisprudencia/toc.jsp.} \mathrm{Acesso} \mathrm{em} \mathrm{21/10/12}$
} 
Decidiu-se que as contribuições pagas pelos filiados à $\mathrm{OAB}$ não têm natureza tributária e que o título executivo extrajudicial, referido no art. 46, parágrafo único, da Lei n. ${ }^{\circ}$ 8.906/94, deve ser exigido em execução disciplinada pelo Código de Processo Civil, não sendo possível a execução fiscal regida pela Lei n. ${ }^{\circ}$ 6.830/80, não estando a instituição submetida às normas da Lei n. ${ }^{\circ}$ 4.320/64, com as alterações posteriores, que estatui normas de direito financeiro dos orçamentos e balanços das entidades estatais e não se encontra a entidade subordinada à fiscalização contábil, financeira, orçamentária, operacional e patrimonial, realizada pelo Tribunal de Contas da União ${ }^{70}$.

Como referência do tratamento dado ao tema, a Lei de Diretrizes Orçamentárias (Lei no 12.708 de 17 de agosto de 2012), quando indica, no art. 6º que os Orçamentos Fiscal e da Seguridade Social compreenderão o conjunto das receitas públicas, bem como das despesas dos Poderes e do Ministério Público da União, seus fundos, órgãos, autarquias, inclusive especiais, e fundações instituídas e mantidas pelo Poder Público, bem como das empresas públicas, sociedades de economia mista e demais entidades em que a União, direta ou indiretamente, detenha a maioria do capital social com

${ }^{70}$ Trecho do acórdão diz que: "Discute-se nos autos o sentido e o alcance do art. 46 da Lei n. ${ }^{\circ}$ 8.906/94 (Estatuto da Advocacia e da Ordem dos Advogados do Brasil - OAB), que apresenta a seguinte redação: "Art. 46. Compete à OAB fixar e cobrar contribuições, preços de serviços e multas. Parágrafo único. Constitui título executivo extra-judicial a certidão passada pela diretoria do Conselho competente, relativa a crédito previsto neste artigo." A simples leitura do dispositivo não permite concluir que as contribuições ali indicadas possuem natureza tributária, como também impede raciocínio conclusivo a respeito do tipo de execução que deve reger à sua cobrança. Os julgados em confronto harmonizam-se quanto ao reconhecimento de que a OAB é uma autarquia de regime especial. Deve-se, então, perquirir o alcance dessa especialidade, para que, ao final, seja possível decidir a respeito da natureza jurídica das anuidades pagas à $\mathrm{OAB}$, bem como do procedimento de execução que deve ser adotado para a cobrança dessas contribuições. Não obstante admita a doutrina possuir a OAB a natureza de autarquia especial ou sui generis, a legislação tem acentuado a sua autonomia em face da estrutura estatal. O Estatuto revogado era taxativo: "Não se aplicam à Ordem as disposições legais referentes às autarquias ou entidades paraestatais" (art. 139, § $1^{\circ}$, da Lei n. ${ }^{\circ}$ 4.215/63). O atual é mais preciso: "a OAB não mantém com órgãos da Administração Pública qualquer vínculo funcional ou hierárquico" (art. 44, § $1^{\circ}$, da Lei n. ${ }^{\circ}$ 8.906/94). Embora constitua serviço público e goze de imunidade tributária em relação a seus bens e suas rendas (art. 44, caput, e art. 45 , $\S 5^{\circ}$, da Lei n. ${ }^{\circ}$ 8.906/94), não há dúvida de que a natureza jurídica da OAB não se ajusta perfeitamente ao conceito de autarquia. Mesmo incumbida de realizar serviço público, nos termos da lei que a instituiu, esse fato não acarreta a sua inclusão entre as demais autarquias federais típicas. Nesse sentido, doutrina Ives Gandra da Silva Martins, verbis : "A entidade que controla todos os advogados é instituída por lei, com personalidade 'sui generis' , pois se a advocacia é uma função essencial à justiça e de proteção da sociedade, a entidade que a controla não pode estar sujeita, nem subordinada ao Poder, tendo plena independência e autonomia financeira, visto que é exclusivamente mantida pelos advogados. É de se lembrar que, muitas vezes, tem-se transformado na única voz do povo, como ocorreu no regime de exceção de 1968 a 1977, quando houve censura de imprensa e a sociedade só se manifestava contra o Estado, através da OAB."("Ordem dos Advogados do Brasil - Perfil Jurídico - Contas Não Sujeitas à Fiscalização do Tribunal de Contas por ser Entidade Não Governamental e Não Contar com Recursos Públicos Aplicados", Revista Fórum Administrativo, Ano 1, n. ${ }^{\circ}$ 5, julho de 2001, p. 599). Não se reveste a OAB da condição de autarquia administrativa, já que não busca realizar os fins da Administração, mas a sua própria missão constitucional e legal”. 
direito a voto e que dela recebam recursos do Tesouro Nacional, devendo a correspondente execução orçamentária e financeira, da receita e da despesa, ser registrada na modalidade total no SIAFI, exclui, pelo parágrafo único, os conselhos de fiscalização de profissão regulamentada, constituídos sob a forma de autarquia. Assim, observa-se margem de liberdade no quesito da fiscalização de tais entidades.

2.2.2.2 - Fundações Públicas e de Apoio.

"Fundação", termo isoladamente despido de atributos e qualificativos é uma categoria jurídica que significa genericamente um patrimônio (conjunto de bens) personalizado e afetado (dirigido, destinado, preordenado) pela vontade de seu instituidor a um fim determinado ${ }^{71}$.

O que coloca a fundação no campo do direito privado ou público é seu regime jurídico.

Houve discussão doutrinária sobre a existência ou não de fundamento legal para as fundações públicas, tendo em vista que o Código Civil de 1916 fazia referência apenas às fundações como sendo pessoas jurídicas de direito privado.

Entretanto, a Constituição Federal de 1988, apesar de um tanto imprecisa, assegurou a existência da fundação pública e da fundação instituída ou mantida pelo Poder Público, como se observa de referências contidas no art. 71, II e III; art. 150, §2º art. 18 das Disposições Transitórias.

Na realidade, as fundações instituídas pelo Poder Público são chamadas de fundações autárquicas (que poderia ser um gênero da espécie autarquia), com referência no Código Civil de 2002 (artigos 41, IV e 44, III)

Há na doutrina quem diga que a expressão "Fundação Pública" (não mais constante da CF, mas ainda em textos como a Lei $n^{\circ} 8.112 / 90$ ) significaria "fundação de

71 SALANDRA, Antonio. Lezioni di diritto amministrativo, Rome, Associazione Universitaria Romana, 1909, p.135 apud ARAÚJO, Edmir Netto de. Curso de Direito Administrativo, ob cit. p. 208. 
direito público" ${ }^{, 72}$, porém Edmir Netto de Araújo $^{73}$ aponta que o termo seria genérico porque na redação antiga do art.37 da Constituição falava-se em administração direta, indireta e fundacional, sendo que as autarquias (fundações de direito público) já estariam incluídas na Administração Indireta e por isso houve a correção da expressão na Emenda Constitucional $\mathrm{n}^{\circ}$ 19/98, mencionando-se, então, somente a Administração Direta e Indireta. Lembra também que a Constituição de São Paulo não se referia ao termo ‘fundações públicas', como se vê do artigo 115, XIX, XXI, XXIV e §5.

Fato é que deve ser considerado que as Fundações Públicas integram a Administração Indireta, ainda que o Decreto-Lei n ${ }^{\circ}$ 200/67 assim não o diga, e assim se afirma porque a Lei $\mathrm{n}^{\mathrm{o}} 7.596 / 87$ ao modificar aquele Decreto o fez para incluir as Fundações Públicas.

Segundo o Decreto-Lei $n^{\circ}$ 200/67, pelo art. 5º, inciso IV, Fundação Pública é a entidade dotada de personalidade jurídica de direito privado, sem fins lucrativos, criada em virtude de autorização legislativa, para o desenvolvimento de atividades que não exijam execução por órgãos ou entidades de direito público, com autonomia administrativa, patrimônio próprio gerido pelos respectivos órgãos de direção, e funcionamento custeado por recursos da União e de outras fontes.

E, conforme o parágrafo terceiro, adquirem personalidade jurídica com a inscrição da escritura pública de sua constituição no Registro Civil de Pessoas Jurídicas, não se lhes aplicando as demais disposições do Código Civil concernentes às fundações.

Também se afirma que integram a administração indireta porque com a promulgação da Lei $\mathrm{n}^{\circ} 8.112$ de 11 de dezembro de 1990, que trata do regime jurídico único de pessoal, os empregos de fundações federais até então existentes foram transformados em 'cargos', submetidos ao regime jurídico estatutário, de direito público, o que, na prática transformou aquelas entidades em fundações autárquicas (visto que entidades privadas não podem ter regime jurídico predominante de direito público -

\footnotetext{
${ }^{72}$ Como em DALlARI, Adilson Abreu. Regime constitucional dos servidores públicos, São Paulo: RT. 1990, p.44 e 45 e MELLO, Celso Antonio Bandeira de. Prestação de serviços públicos e administração indireta. São Paulo: RT. 1975, p.147

${ }^{73}$ ARAÚJO, Edmir Netto de. Curso de Direito Administrativo, ob cit. p. 210/211
} 
ressalvadas as derrogações diante da prestação de serviços públicos - ou quadros de servidores estatutários).

A fundação pública é criada por lei, portanto, o próprio poder instituidor (Legislativo), com auxílio do Tribunal de Contas (art. 71, II e III da CF) as controla. Por ser pessoa jurídica de direito público, traz consigo o poder de império próprio do Poder Público, do qual se destaca especialmente o poder de polícia, que dá suporte à execução de seus atos, em tudo idêntico aos atos administrativos, que em verdade são por elas praticados. $^{74}$

O patrimônio das fundações estatais é de origem pública, mesmo se destinado a entidade de regime jurídico privado e sua disposição (afetação, destinação) se subordina à autorização legislativa genérica (se decorrente da lei que autorizou a criação da entidade) ou específica (para cada caso concreto). A gestão do patrimônio é da própria entidade e as responsabilidades decorrentes da gestão de seus agentes e dirigentes em regime similar ao dos bens públicos e das 'Fazendas'. Tal patrimônio é impenhorável, exceto de prestadora de serviços, não se aplicando a execução especial que é prerrogativa da Fazenda Pública ${ }^{75}$.

É possível também a existência de Fundações instituídas pelo Poder Público com personalidade jurídica de direito privado, as chamadas 'paraestatais', quando o Estado pretende maior elasticidade na gestão.

São entidades criadas após edição de lei autorizadora (art. 37, XIX da CF, com redação da EC 19/98 e art. 1º, inciso II da Lei n ${ }^{\circ}$ 7.596/87), com destinação patrimonial, com o Poder Executivo se encarregando de completar a formalização do futuro ente, por meio de regulamentação via decreto, indicando ainda a autoridade que deverá comparecer ao Tabelionato de Notas para lavrar escritura pública que será levada para averbação no Registro Civil das Pessoas Jurídicas (art. 64 do Código Civil e 114, I da Lei de Registros Públicos).

\footnotetext{
${ }^{74}$ GRAZZIOLI, Airton e RAFAEL, José Edson. Fundações Privadas. São Paulo: Atlas. 2009, p; 53

${ }^{75}$ ARAÚJO, Edmir Netto de. Curso de Direito Administrativo, Ob, cit, p.216.
} 
Eventuais benefícios devem ser previstos por lei especial e eventuais vantagens não descaracterizam os entes paraestatais, sendo o regime jurídico de pessoal o da Consolidação das Leis do Trabalho (conforme Lei nº 9.962 de 22 de fevereiro de 2000).

São entes de cooperação (e não longa manus do Estado, como as autárquicas), com objetivo de interesse público, amparadas economicamente pelo Estado, que controla suas atividades bem como as receitas a ela destinadas, ainda que mantidas no direito privado por exercerem atividades delegadas. Objetivam atividades não lucrativas mas de interesse coletivo como educação, cultura e pesquisa científica.

Ainda assim, submetem-se a controle administrativo direto pela própria entidade que a instituiu, abrangendo os atos de seus dirigentes e a gestão financeira (art. 49, $\mathrm{X}$ da $\mathrm{CF}$ ) e apesar dos funcionários e dirigentes não serem servidores públicos propriamente ditos podem, em certos casos, ser considerados agentes públicos, conforme o modelo de investidura e as funções delegadas que exerçam.

Significa dizer que podem responder por ato de improbidade administrativa, e para fins criminais, em caso de mandado de segurança, ação popular e ação civil pública são considerados funcionários públicos (art. 327 do Código Penal) e autoridades, quando exercerem funções delegadas pelo Poder Público (art. $1^{\circ}$, $\S 1^{\circ}$ da Lei $n^{\circ} 1.533$ de 31 de dezembro de 1951 e art. 5 $5^{\circ}$ LXIX da CF; art. $1^{\circ}$ da Lei no 4.717 de 29 de junho de 1965 e art. $5^{\circ}$ LXXIII da CF; e art. $5^{\circ}$ da Lei $n^{\circ} 7.347$ de 24 de julho de 1985$)^{76}$.

É obrigatório, ainda, que para assumir cargo ou função seja feita a declaração de bens, conforme Lei $n^{\circ} 6.728$ de 22 de novembro de 1979 e ficam obrigadas tais entidades a proceder a Licitação para contratação de obras, serviços e compras, conforme Lei $\mathrm{n}^{\circ} 8.666$ de 21 de junho de 1993.

\subsubsection{3 - Empresas Estatais.}

O termo é genérico e agrupa as empresas públicas e as sociedades de economia mista (subdivisão não unânime na doutrina).

\footnotetext{
${ }^{76}$ GRAZZIOLI, Airton e RAFAEL, José Edson. Fundações Privadas. São Paulo: Atlas. 2009, p; 55
} 
Neste grupo podem ser designadas todas as sociedades civis ou comerciais das quais o Estado tem o controle acionário. São traços comuns às empresas públicas e às sociedades de economia mista, segundo Maria Sylvia Zanella Di Pietro ${ }^{77}$ : criação e extinção por lei; personalidade jurídica de direito privado; sujeição ao controle estatal; derrogação parcial de normas de direito comum pelo direito público; vinculação aos fins instituídos na lei instituidora e desempenho de atividade de natureza econômica.

Lembra a citada autora que a Emenda Constitucional 19/98 corrigiu uma falha do art. 37, inciso XIX, da Constituição, que exigia lei específica para a criação de entidades da Administração indireta ${ }^{78}$. Assim, no caso de sociedade de economia mista, empresa pública e fundação, a lei não cria as entidades, mas apenas autoriza a criação, que se processa por atos constitutivos do Poder Executivo e transcrição no Registro Público.

\subsubsection{1 - Empresas Públicas.}

Em regra, criada pelo Estado, esta entidade presta seus serviços no campo da atividade econômica privada, nos termos e limites fixados pela legislação e pela Constituição Federal.

Em se tratando da definição de uma empresa pública, necessária se torna a transcrição do artigo 5, inciso II, do Decreto-Lei 200/67: “... Empresa pública: a entidade dotada de personalidade jurídica de direito privado, com patrimônio próprio e capital exclusivo da União, criada por lei para a exploração de atividade econômica que o governo seja levado a exercer por força de contingência administrativa, podendo revestirse de qualquer das formas admitidas em direito".

O Ministério da Fazenda disponibiliza em seu sítio eletrônico o seguinte ${ }^{79}$ : “Entidade empresarial, com personalidade jurídica de direito privado e participação única do Poder Público no seu capital e direção, na forma da lei, sendo de propriedade única do Estado. É pessoa jurídica de direito privado, sem privilégios estatais, salvo as

\footnotetext{
${ }^{77}$ DI PIETRO, Maria Sylvia Zanella. Direito Administrativo, $23^{\text {a }}$ Ed. São Paulo: Atlas, 2010, p.446

${ }^{78}$ XIX - somente por lei específica poderá ser criada autarquia e autorizada a instituição de empresa pública, de sociedade de economia mista e de fundação, cabendo à lei complementar, neste último caso, definir as áreas de sua atuação.

${ }^{79}$ www.fazenda.gov.br - Acesso em 29.08.2011
} 
prerrogativas que a lei especificar em cada caso particular, para a realização das atividades desejadas pelo Poder Público".

Segundo a doutrina de Diógenes Gasparini ${ }^{80}$ : “[Empresa pública é] a sociedade mercantil-industrial, constituída mediante autorização de lei e essencialmente sob a égide do Direito Privado, com capital exclusivamente da Administração Pública ou composto, em sua maior parte, de recursos dela advindos e de entidades governamentais, destinadas a realizar imperativos da segurança nacional e relevantes interesses da comunidade".

E para Celso Antônio Bandeira de Mello ${ }^{81}$ : "Empresa Pública federal é a pessoa jurídica criada por força de autorização legal como instrumento de ação do Estado, dotada de personalidade de Direito Privado, mas submetida a certas regras especiais decorrentes de ser coadjuvante da ação governamental, constituída sob quaisquer das formas admitidas em Direito e cujo capital seja formado unicamente por recursos de pessoas de Direito Público interno ou de pessoas de suas Administrações indiretas, com predominância acionária residente na esfera federal”.

Assim, empresas públicas podem ser criadas sob qualquer forma societária, e aquelas da União têm instância de julgamento perante a Justiça Federal (art.109, I da CF). Estão sujeitas a falência e são constituídas pelo capital da própria Administração.

2.2.2.3.2 - Sociedades de Economia Mista.

O Decreto-Lei $\mathrm{n}^{\circ} 200$, de 25 de fevereiro de 1967 , enuncia no art. $5^{\circ}$, inciso III, que sociedade de economia mista é "a entidade dotada de personalidade jurídica de direito privado, criada por lei para a exploração de atividade econômica, sob a forma de sociedade anônima, cujas ações com direito a voto pertençam em sua maioria à União ou a entidade da Administração Indireta”.

\footnotetext{
${ }^{80}$ GASPARINI, Diógenes. Direito Administrativo. $8^{\text {a }}$ Ed. São Paulo: Saraiva, 2003, p.360

${ }^{81}$ MELLO, Celso Antonio Bandeira de Curso de Direito Administrativo. 26a Ed. São Paulo: Malheiros, 2009, p. 186.
} 
Também o sítio eletrônico do Ministério da Fazenda ${ }^{82}$ define como "entidade dotada de personalidade jurídica de direito privado, criada por lei para o exercício de atividade econômica, sob a forma de sociedade anônima, cujas ações com direito a voto pertençam em sua maioria ao Poder Público”.

Para Celso Antonio Bandeira de Mello ${ }^{83}$ "sociedade de economia mista federal é a pessoa jurídica cuja criação é autorizada por lei, como um instrumento de ação do Estado, dotada de personalidade de Direito Privado, mas submetida a certas regras especiais decorrentes desta natureza auxiliar da atuação governamental, constituída sob a forma de sociedade anônima, cujas ações com direito a voto pertençam em sua maioria à União ou entidade de sua Administração indireta, sobre remanescente acionária de propriedade particular".

E segundo Maria Sylvia Zanela di Pietro ${ }^{84}$ : “(...) a sociedade de economia mista é pessoa jurídica de direito privado, em que há conjugação de capital público e privado, participação do poder público na gesta e organização sob forma de sociedade anônima, com as derrogações estabelecidas pelo direito público e pela própria lei das S.A. (Lei n. 6404, de 15-12-76); executa atividades econômicas, algumas delas próprias da iniciativa privada (com sujeição ao art. 173 da Constituição) e outras assumidas pelo Estado como serviços públicos (com sujeição ao art. 175 da Constituição) ’”.

Assim, vê-se que são pessoas jurídicas criadas por lei como elemento de ação do Estado e tem como característica a natureza privada, ainda que adstritas às regras de direito público, diante de sua função auxiliadora da ação estatal. Aqui temos associação do patrimônio público e do patrimônio privado.

A maioria de suas ações relativas a votos e decisões (lembrando que somente podem assumir a forma de sociedades anônimas conforme Lei 6.404/1976, art. 235 - Lei das Sociedades Anônimas ${ }^{85}$ ) deve pertencer à União, Estado ou Município ou

${ }^{82}$ www.fazenda.gov.br - Acesso em 29/08/2011

${ }^{83}$ MELLO, Celso Antonio Bandeira de Curso de Direito Administrativo. 26a Ed. São Paulo: Malheiros, 2009, p.190-191.

${ }^{84}$ DI PIETRO, Maria Sylvia Zanella. Direito Administrativo, $18^{\text {a }}$ Ed. São Paulo: Atlas, 2010

${ }^{85}$ Art. 235. As sociedades anônimas de economia mista estão sujeitas a esta lei, sem prejuízo das disposições especiais de lei federal. $\S 1^{\underline{0}}$ As companhias abertas de economia mista estão também sujeitas às normas expedidas pela Comissão de Valores Mobiliários. § $2^{\underline{0}}$ As companhias de que participarem, majoritária ou 
ainda outra entidade da administração indireta (conforme art.5 $5^{\circ}$, inciso III do Decreto-lei 200/1967).

O mesmo Decreto-Lei ${ }^{\circ}$ 200/67 aponta que o Poder Executivo enquadrará as entidades da Administração Indireta existentes nas categorias constantes no artigo, permitindo assim que, alguma entidade porventura não adequada à primeira vista aos conceitos, seja formalmente adequada a uma das categorias.

2.2.3 - A Comissão Interministerial de Governança Corporativa e de Administração de Participações Societárias da União.

A título de ilustração, é de se mencionar que em 22 de janeiro de 2007, pelo Decreto $n^{0}$ 6.021 foi criada a "Comissão Interministerial de Governança Corporativa e de Administração de Participações Societárias da União" (CGPAR), com a finalidade de tratar de matérias relacionadas com a governança corporativa nas empresas estatais federais e da administração de participações societárias da União.

Segundo o Decreto, consideram-se: I - empresas estatais federais: as empresas públicas, sociedades de economia mista, suas subsidiárias e controladas e demais sociedades em que a União, direta ou indiretamente, detenha a maioria do capital social com direito a voto; II - participações: os direitos da União decorrentes da propriedade, direta ou indireta, do total ou de parcela do capital de sociedades; III - administração de participações: todas as atividades administrativas relacionadas ao exercício das funções de acionista, quotista ou proprietário do capital de empresas; e IV - governança corporativa: conjunto de práticas de gestão, envolvendo, entre outros, os relacionamentos entre acionistas ou quotistas, conselhos de administração e fiscal, ou órgãos com funções equivalentes, diretoria e auditoria independente, com a finalidade de otimizar o desempenho da empresa e proteger os direitos de todas as partes interessadas, com transparência e eqüidade, com vistas a maximizar os resultados econômico-sociais da atuação das empresas estatais federais;

minoritariamente, as sociedades de economia mista, estão sujeitas ao disposto nesta lei, sem as exceções previstas neste capítulo. 
Compõem a comissão os Ministros de Estado do Planejamento, Orçamento e Gestão, que a preside, da Fazenda; e o Chefe da Casa Civil da Presidência da República, sendo que podem ser convidados a participar das reuniões, porém sem direito a voto, os Ministros de Estado responsáveis pela supervisão de empresas estatais com interesse nos assuntos objeto de deliberação, bem como dirigentes e conselheiros de administração e fiscal das empresas estatais federais e representantes de outros órgãos ou entidades da administração pública federal, responsáveis por matérias a serem apreciadas.

Compete à comissão aprovar diretrizes e estratégias relacionadas à participação acionária da União nas empresas estatais federais, com vistas à defesa dos interesses da União, como acionista; promoção da eficiência na gestão, inclusive quanto à adoção das melhores práticas de governança corporativa; aquisição e venda de participações detidas pela União, inclusive o exercício de direitos de subscrição; atuação das empresas estatais federais na condição de patrocinadoras de planos de benefícios administrados por entidades fechadas de previdência complementar; fixação da remuneração de dirigentes; fixação do número máximo de cargos de livre provimento; expectativa de retorno do capital dos investimentos com recursos da União; distribuição de remuneração aos acionistas; e divulgação de informações nos relatórios da administração e demonstrativos contábeis e financeiros, no caso das empresas públicas e sociedades de capital fechado.

Também incumbe estabelecer critérios para avaliação e classificação das empresas estatais federais, com o objetivo de traçar políticas de interesse da União, tendo em conta, dentre outros, os aspectos de desempenho econômico-financeiro, práticas adotadas de governança corporativa, gestão empresarial, setor de atuação, porte, ações negociadas em bolsas de valores nacionais e internacionais e recebimento de recursos do Tesouro Nacional a título de despesas correntes ou de capital.

Deverá também estabelecer critérios e procedimentos, a serem adotados pelos órgãos competentes, para indicação de diretores e dos representantes da União nos conselhos de administração e fiscal das empresas estatais federais, observados, dentre outros, os requisitos de capacitação técnica, conhecimentos afins à área de atuação da empresa e à função a ser nela exercida e reputação ilibada; além de estabelecer diretrizes para a atuação dos representantes da União nos conselhos de administração e físcal, ou 
órgãos com funções equivalentes, das empresas estatais federais e de sociedades em que a União participa como minoritária e estabelecer padrão de conduta ética dos representantes da União nos conselhos de administração e fiscal das empresas estatais federais e de sociedades em que a União participa como minoritária, sem prejuízo das normas já definidas pela própria sociedade; além de poder aprovar o seu regimento interno, mediante resolução.

Tendo em vista o disposto no art. $8^{\circ}-\mathrm{C}$ da Lei $\mathrm{n}^{0} 9.028$, de 12 de abril de 1995, a comissão poderá recomendar ao Advogado-Geral da União a avocação, a integração ou a coordenação dos trabalhos a cargo de órgão jurídico de empresa estatal, na defesa dos interesses da União e em hipóteses que possam trazer reflexos de natureza econômica, ainda que indiretos, ao erário federal.

Compete aos dirigentes de órgãos da administração pública federal e aos representantes da União nos conselhos de administração e fiscal das empresas estatais federais, respeitadas suas atribuições legais e estatutárias, adotar as medidas necessárias à observância das diretrizes e estratégias da comissão.

\subsection{4 - Conclusão do Capítulo.}

Portanto, observa-se a preocupação da União em aperfeiçoar sua participação na administração pública indireta.

Pontue-se que no tema da administração pública indireta, a função executiva é a que acontece, na prática, posto que não há como se pensar em deixar para outros entes funções jurisdicionais (embora seja possível pensar em arbitramento realizado por terceiros e execução de penas fora do âmbito de execução do Poder Judiciário, mesmo que sob sua responsabilidade) ou legislativas (ainda que comandos normativos emanem de órgãos administrativos, tais como dos Conselhos de Fiscalização do Ministério Público e do Poder Judiciário - CNMP e $\mathrm{CNJ}^{86}$, respectivamente), não podendo estar isentos estes outros de

\footnotetext{
${ }^{86} \mathrm{O}$ tema referente aos órgãos de controle da Magistratura e do Ministério Público é polêmico, e um de seus exintegrantes $(\mathrm{CNJ})$ já questionou suas atribuições (embora o tenha feito antes de integrar o Conselho): ...A criação de um órgão autônomo e externo ao Poder Judiciário, com a missão de fiscalizá-lo e controlá-lo, acabaria por desrespeitar flagrantemente os arts. $2^{\circ}$ e $60, \S 4^{\circ}$, III da Constituição Federal, configurando-se em uma intervenção dos demais poderes na magistratura, que ficaria submetida hierárquica e politicamente
} 
também prestar contas à sociedade, embora ainda embrionária a questão, diante da novicidade dos órgãos.

Assim, visto o tema das entidades da administração pública, passa-se ao estudo das expressões 'controle e ‘ fiscalização’ de modo mais específico.

a um órgão político, composto por integrantes pertencentes aos demais Poderes ou instituições estatais, e, em consequência, haveria o grave risco de comprometimento da imparcialidade dos magistrados". (MORAES, Alexandre de. Controle externo do Poder Judiciário. Revista de Informação Legislativa, Brasilia, $n^{\circ}$. 140, p.59-64, out/dez1998). N.a.- Fato é que os Conselhos são uma realidade e assim devem ser analisados enquanto se estabelecem os limites de sua atuação, da mesma forma que deve se admitir a plena necessidade de que também prestem contas à sociedade, devendo ser fiscalizados em suas contas e em seus patrimônios. 


\section{CAPÍTULO 3 - CONTROLE E FISCALIZAÇÃO}

3.1 - Introdução.

Falar em controle e fiscalização da administração pública pressupõe trabalhar, inicialmente, nos conceitos, isto é, o que é controle e o que é fiscalização. Também indagar porque se deve exercer controle e fiscalização, em especial no setor da administração pública.

Antes, porém, cabe abordar o tema da responsabilidade, como pressuposto de controle e fiscalização. Isto por que é exigível do Estado e, portanto, da administração pública um agir responsável ${ }^{87}$. Na medida em que seria utópico pensar que o administrador público será responsável simplesmente porque o deveria ser, temos a necessidade de estabelecer mecanismos que permitam que seja fiscalizado e controlado, visando orientação e/ou punição por ações ou omissões. Também pontuar a diferença entre a responsabilidade do Estado e seus agentes frente ao administrado (e o dever de indenizar) e a responsabilidade exigida de quem detém atribuição junto ao foco central de Poder (objeto da prestação de contas e da fiscalização).

3.2 - A Responsabilidade:

O ser humano, como já mencionado, tendo em vista sua natureza social, de viver em comunidade, necessita de regras básicas de convivência. Com elas têm-se a possibilidade de disciplinar o comportamento de seus membros, no interesse coletivo da preservação da paz, do bem-estar social, e de todos os demais valores envolvidos.

Existe a consciência de que os comportamentos podem ser devidos ou indevidos (vedados) relativos a cada circunstância e os próprios membros da comunidade é que devem estabelecer quais pertencerão a qual categoria, fixando, também, a repreensão frente à não obediência. Este é o caminho para que a coexistência aconteça de forma equilibrada.

\footnotetext{
${ }^{87}$ José Mauricio Conti lembra em artigo publicado junto com André Castro Carvalho, logo no resumo inicial que "o controle interno, modernamente, possui função essencial para uma gestão fiscal responsável no Brasil”. O controle interno na Administração Pública brasileira: Qualidade do gasto público e responsabilidade fiscal. Revista de Direito Público, ano VIII, nº 37, jan-fev.2011.(Negrito não original).
} 
Trata-se do chamado controle social, que pode ser interno ou externo ${ }^{88}$. O interno acontece quando os indivíduos internalizam normas de uma cultura como resultado de um processo de socialização bem sucedido e, portanto, seguindo a norma quase como um reflexo, já que motivados por fatores de consciência. O externo subdivide-se em informal ou formal. Aquele, mais comum nos grupos primários (família, amigos etc.), acontece por meio de ações que ridicularizam os indivíduos, falatórios, fofocas, riso, ostracismo restando eficiente na medida do medo da desaprovação social; enquanto que este último deriva do exercício de organizações ou agências formadas na sociedade (como órgãos policiais, organismos de assistência social, tribunais etc.).

À medida que o controle social se torna mais formalizado, maior será a probabilidade de que se torne mais racional e objetivo ${ }^{89}$.

Sendo assim, é correto afirmar que os comportamentos humanos devem se revestir de algo a que chamamos 'responsabilidade', que é um conceito complexo que perpassa desde a filosofia, até o direito, e que na linguagem comum guarda nexo com o atributo do indivíduo ter consciência dos próprios deveres.

A palavra tem origem latina, no verbo respondere que, em sentido próprio significava corresponder a um compromisso solenemente feito (segundo Plauto) e na linguagem popular, comum, significava responder (Cícero) ${ }^{90}$.

"A conotação da palavra responsabilidade é sempre estabelecida com a idéia de imputabilidade a alguém, relativamente ao desequilíbrio que esse alguém causou na ordem regular ou natural das coisas." 91.

Assim, não há dúvida de que o enfoque de responsabilidade aponta para um agir consoante o regramento estabelecido pelo próprio grupo social sob pena de alguma sanção.

\footnotetext{
${ }^{88}$ Aqui não se trata de confundir com o sistema de fiscalização dos órgãos públicos, que pode ser interno ou externo, como será estudado no trabalho. Refere-se o trecho a um conceito da Sociologia sobre o controle social.

${ }^{89}$ COHEN, Bruce. Sociologia Geral. São Paulo: McGraw-Hill do Brasil, 1980, p.79

${ }^{90}$ FARIA, Ernesto - org. -Dicionário Escolar Latino-Português, 3a. Ed.Rio de Janeiro: MEC, 1962,p.865.

${ }^{91}$ ARAÚJO, Edmir Netto de. Curso de Direito Administrativo. São Paulo, Saraiva, 2006.p.720
} 
Observa-se, entretanto, que o enfoque jurídico é, via de regra, calcado na importância que se dá ao tema do ressarcimento, e, em especial no ramo do direito público quando de lesão acontecida derivada de ação ou omissão da administração pública, seja do agente, seja de seus órgãos.

"Responsabilidade significa a obrigação de reparar um prejuízo, seja por decorrer de uma culpa ou de uma outra circunstância legal que a justifique, como a culpa presumida, ou por uma circunstância meramente objetiva" ${ }^{92}$.

Neste sentido, Émerson Gomes ${ }^{93}$ afirma que na acepção técnica, a palavra 'responsabilidade' significa sujeição às consequências do ilícito (sanção) às quais está submetido aquele que comete o ilícito ou alguém a ele vinculado por determinada relação prescrita na ordem jurídica. Assim, o dever originário é que define, via de regra, o responsável (por fato próprio, aquele que está obrigado a cumprir o dever) ou algum terceiro ligado a certo vínculo jurídico (responsabilidade por fato de terceiro).

Em realidade, refere-se tal conceito à responsabilidade jurídica e que dentre critérios da doutrina para diferir suas espécies, temos: a natureza do dever violado; o órgão competente para aplicar sanção; a gravidade da ofensa ao ordenamento jurídico; o bem jurídico restringido ou suprimido pela sanção; a função da sanção e a cumulatividade entre elas.

Entretanto, há necessidade de se discutir não somente tal enfoque do termo 'responsabilidade' (vale dizer, com nexo de causalidade quanto ao ressarcimento), mas também sob ótica distinta, qual seja, aquela que aponta para necessidade de se fiscalizar os atos da administração pública e a possibilidade de orientar e prevenir ações ou mesmo punir, seja enquanto ente, seja no que pertine a seus atores (que agem em seu nome), em seu escopo de realizar o fim para o qual existe - o bem estar social.

\footnotetext{
${ }^{92}$ LOPES, Miguel Maria de Serpa. Curso de Direito Civil. Rio de Janeiro: Freitas Bastos, 1961, vol.V, p.188-189.

93 GOMES, Emerson Cesar da Silva. Responsabilidade Financeira. Porto Alegre: Nubia Fabris Editora. 2012. P.24-25
} 
Deve se tomar por pressuposto que o agir do administrador público deve, necessariamente, refletir em bem estar dos indivíduos que compõem determinado grupo social, e o seu agir responsável poderá ser precedido de orientações ou sucedido de repreensões, se equivocado (e distintos órgãos estarão envolvidos em tal tarefa, como será visto nos capítulos seguintes).

Assim, diferentemente do enfoque estritamente jurídico (que visa ressarcimento a partir do trinômio: dever jurídico, sanção e responsabilidade) propõe-se a necessidade de um conceito que seja semelhante ao senso comum, porém qualificado em razão da natureza do exercício de uma função voltada para o público, ao qual se atribui o nome de responsabilidade por princípios.

\subsection{1 - Responsabilidade Civil e Responsabilidade por Princípios}

Cabe, brevemente, para que não surja alguma confusão com os temas, mencionar, então, a distinção entre a chamada ' responsabilidade civil do Estado' (que não é o objeto do presente trabalho) da 'responsabilidade' aqui tratada e que se refere ao dever de respeito ao múnus de servir à sociedade, agora batizada de 'responsabilidade por princípios'.

Por primeiro a responsabilidade civil do Estado.

Dizer que o Estado é responsável, mesmo no caso de atos lícitos, é dizer que há obrigação estatal de responder pelos danos impostos a terceiros em virtude do atendimento do máximo interesse público com sacrifício de determinado interesse particular.

É sabido que no Estado de Direito a lei regula os direitos individuais e os coletivos, amparando quem sofre lesão em seus direitos, sem o favoritismo do tempo do Estado absolutista. Em nossa realidade também o Estado se amolda à necessidade de obediência ao comando normativo, submetendo-se ao ordenamento jurídico cujo ideário de justiça social tem a legalidade como regra e a igualdade como princípio. 
Em sentido amplo, o Estado, como pessoa jurídica de direito público, pratica atos visando o regular funcionamento da máquina administrativa e o prover das necessidades da coletividade a que se destina administrar.

O tema abarca, necessariamente, as diversas funções de poder que o Estado exerce, vale dizer, judiciária, executiva e legislativa e segundo Edmir Netto de Araújo a atividade ou função de deliberação compreende "o estabelecimento de regras gerais $e$ impessoais de direito às quais todos deverão obedecer" 94 .

Poderá em tal situação, e, em virtude de sua atuação, motivar prejuízos a terceiros, devendo, em face da lei, recompor o dano. José Cretella Junior diz que "Não há responsabilidade sem prejuízo e o prejuízo é o dano" ${ }^{95}$.

Assim, diante da tal possibilidade (do Estado causar lesão a terceiros), seja por comportamento omissivo ou comissivo, legítimo ou ilegítimo, a questão da responsabilidade civil implica no reconhecimento de que tem o dever de recompor o patrimônio afetado.

Deixando de lado o aprofundamento na questão da terminologia, ainda que citando-a, perfunctoriamente, temos que se a responsabilidade decorre de ato ilícito o Estado deveria `ressarcir`e se de ato lícito, deveria `indenizar`. Isto porque esta última seria instituto típico de direito administrativo e consequente dos atos lícitos da administração. Não há unanimidade na doutrina a este respeito ${ }^{96}$.

A responsabilidade pode ser contratual ou extracontratual e no primeiro caso indeniza-se quando há desrespeito às cláusulas pactuadas como substitutivo da obrigação prevista e na segunda recompõe-se o dano se há violação do dever jurídico de dar, fazer ou deixar de fazer algo, que, se não satisfeito, cause lesão. Vale, dizer, no primeiro caso são os chamados atos ilícitos e no segundo os lícitos.

\footnotetext{
${ }^{94}$ ARAÚJO, Edmir Netto de. Responsabilidade do Estado por ato jurisdicional, São Paulo: RT, 1981

${ }^{95}$ CRETELLA JUNIOR, Jose. O Estado e a obrigação de indenizar. São Paulo: Saraiva, 1980

96 TRUJILLO, Élcio. Responsabilidade do Estado por ato lícito. São Paulo: Editora de Direito, 1996, p.40
} 
Na medida em que a administração pública detém características próprias que lhe permitem agir em favor da coletividade, balizada por parâmetros traçados na própria norma jurídica, por vezes, no exercício de suas funções pode causar ao administrado uma necessidade de que este suporte algo mais do que aquele necessário suportado por todos os demais.

Então, mesmo agindo com comportamento lícito pode causar dano ao particular, que, deverá ser indenizado proporcionalmente ao sacrifício imposto no que Élcio Trujillo ${ }^{97}$ chama de conversão de direitos, sendo indispensáveis à indenização além da certeza do dano e da lesão a um direito, outras duas características, a saber, especialidade e anormalidade.

Reconhece-se, doravante, que a atuação do Estado ainda que detentora de Poder e com possibilidade de agir de forma superlativa se comparada com a relação permitida entre os particulares encontra óbices quando exige sacrifício especial e anormal do particular (um seu administrado), vindo causar-lhe lesão e dano reconhecível, exigindose, portanto, do ente maior que recomponha aquele dano.

É a busca cada vez mais intensa do necessário equilíbrio entre o poder conferido pela sociedade ao Estado e o uso de tal poder em benefício da mesma sociedade.

Já a 'responsabilidade por princípios' diz respeito àquela exigida de quem detém o múnus de servir à sociedade, independente do resultado de uma ou mais ações ou omissões. É evento intrínseco à própria atividade desenvolvida e trata do correto agir do administrador público em favor da sociedade, calcado nos princípios constitucionais (já estudados) que disciplinam sua atividade.

Tal agir se materializa no diuturno exercício da gestão do patrimônio público diante do encargo assumido por quem detém parcela do poder conferido pelo grupo social a que pertença.

${ }^{97}$ TRUJILLO, Élcio. Responsabilidade do Estado por ato lícito. São Paulo: Editora de Direito, 1996 
Esta 'responsabilidade por princípios' é que faz com que seja exigida do administrador público a prestação de contas de seus atos e abre a perspectiva do exercício da fiscalização e do controle, que resulta tanto em caráter preventivo-orientador, como repressivo ou punitivo, se a circunstância extrema assim o exigir.

Todo cidadão que atua em órgão da administração pública, seja direta ou indireta, ou mesmo em qualquer atividade que envolva um interesse do grupo social, por delegação de poder, representatividade política ou assemelhado, deve ter como pressuposto de sua atuação que o lucro de sua atividade não é a remuneração do capital, como conhecida, mas sim a satisfação daquele para quem presta o serviço, seja um outro cidadão individualmente considerado, seja uma coletividade.

Logo, requisito prévio para o exercício de um cargo ou função pública ou assemelhado é a internalização comportamental por parte do cidadão de que tem consigo a ‘responsabilidade por princípios” e que deve agir, sempre, a partir dela.

Exemplo típico do que se menciona pode ser encontrado no art. 169 da Lei Complementar Estadual no 734/93 (Lei Orgânica do Ministério Público do Estado de São Paulo), que dentre outro comandos indica que são deveres funcionais dos membros do Ministério Público, além de outros previstos na Constituição e na lei: manter, pública e particularmente, conduta ilibada e compatível com o exercício do cargo; zelar pelo prestígio da Justiça, por suas prerrogativas e pela dignidade de suas funções e ainda pelo respeito aos membros do Ministério Público, aos Magistrados e Advogados; tratar com urbanidade as partes, testemunhas, funcionários e auxiliares da Justiça além de desempenhar com zelo e presteza as suas funções ${ }^{98}$. Recorde-se, ainda, o que foi mencionado no item 2.1.1.3 sobre o Código de Ética Profissional do Servidor Público Civil do Poder Executivo Federal e as respectivas regras deontológicas.

\footnotetext{
98 Também conforme art. 134, o Conselho Superior do Ministério Público deve levar em consideração para efeito de merecimento, quando de promoção ou remoção de cargo, a conduta do membro do Ministério Público na sua vida pública e particular e o conceito de que goza na comarca; a operosidade e a dedicação no exercício do cargo; a presteza e a segurança nas suas manifestações processuais; a frequência e o aproveitamento em cursos oficiais, ou reconhecidos, de aperfeiçoamento; o aprimoramento de sua cultura jurídica, através da publicação de livros, teses, estudos, artigos e obtenção de prêmios relacionados com sua atividade funcional, dentre outros. Nota-se a referência à forma de agir do membro do Ministério Público.
} 
Portanto, pode-se dizer que a palavra responsabilidade permite conotações distintas, uma quando enseja o estudo da indenização ou recomposição do dano e outra quando exige do agente público um pressuposto para sua ação, enquanto ao doutrinador, ao legislador e ao operador do direito exige-se o conhecimento das competências e atribuições dos órgãos e agentes públicos para efetivação dos mecanismos de fiscalização da administração pública, objeto que aqui se discute.

\section{3 - Controle e Fiscalização:}

Os conceitos sobre fiscalização e controle de certa forma se confundem. Apresentam sinonímia para expressar, frente à administração pública, vigilância permanente sobre atos praticados por autoridades e servidores públicos, entretanto, é possível se afirmar que há diferenças de enfoque, por vezes sutis e em outras nem tanto.

Caberia indagar se estaríamos diante de mera questão semântica ou não. $\mathrm{O}$ termo fiscalizar deriva de fiscal, que significa autoridade do fisco. Remonta à expressão latina fiscus (tesouro público). Já o termo controle deriva do francês controle (contrerôle) que significa exemplar do catálogo dos contribuintes em que se verifica a operação do exator (recebedor de impostos ou arrecadador de rendas públicas).

Temos em alemão: "Revision e Kontrolle"; em francês: "Verification e Contrôle" e em inglês: "Supervision e Control".

Se distinção há seria no sentido de emprestar ao termo 'fiscalização' um sentido mais abrangente na estrutura do sistema, reservando-se ao 'controle' grau mais específico ou de forma outra, a utilização do termo 'controle' para as fases iniciais dos procedimentos (por exemplo, o orçamento), contendo exame para aprovação, com caráter preventivo e orientador e 'fiscalização' para momento final (por exemplo, abrangendo a execução do orçamento pelos Poderes e a ação do Poder Legislativo por meio de CPI's ou atividades das Comissões Permanentes, no exercício de suas funções típicas ${ }^{99}$ ), dentre outras distinções.

\footnotetext{
${ }^{99}$ MORAES, Alexandre. Direito Constitucional. São Paulo: Atlas, 1999. P. 346
} 
O Decreto Lei n 200/66 prevê no art. 13 que "O contrôle das atividades da Administração Federal deverá exercer-se em todos os níveis e em todos os órgãos, compreendendo, particularmente: a) o contrôle, pela chefia competente, da execução dos programas e da observância das normas que governam a atividade específica do órgão controlado; b) o contrôle, pelos órgãos próprios de cada sistema, da observância das normas gerais que regulam o exercício das atividades auxiliares; e c) o contrôle da aplicação dos dinheiros públicos e da guarda dos bens da União pelos órgãos próprios do sistema de contabilidade e auditoria.

E no art.14 que "O trabalho administrativo será racionalizado mediante simplificação de processos e supressão de contrôles que se evidenciarem como puramente formais ou cujo custo seja evidentemente superior ao risco".

A concepção de controle é diversa entre os países latinos e anglosaxões. Para aqueles se aproxima do significado de "verificação ou exame", enquanto que para estes últimos de "guia, impulso corretivo"100, mostrando certa ideia de proatividade diante do enfoque mais preventivo do que propriamente repressivo ${ }^{101}$, representando instrumento de aferição de boa conduta quanto aos objetivos pretendidos.

Para a Organização para a Cooperação e Desenvolvimento Econômico $(\mathrm{OCDE})^{102}$, controle é “... o conjunto de mecanismos que permitem normalmente assegurar a eficácia e a eficiência das atividades, a fiabilidade das informações produzidas e o respeito às leis e aos regulamentos aplicáveis. (...) Os controles internos são os métodos, as regras e as modalidades de organização da gestão que permitem aos

\footnotetext{
${ }^{100}$ SPINELLI, Mario Vinicius Claussen. Brasil e Estados Unidos: O sistema de controle interno do poder executivo federal em perspectiva comparada. Revista da CGU, $6^{a}$ ed. p.38, set.2009.

${ }^{101}$ CARTES, Juan Eduardo Toledo. El control interno de La administracion: modernización de lós sistemas como uma emergencia. VIII Congresso Internacional de CLAD sobre La reforma Del Estado y de la Administracion Pública, Panamá, 28-31 oct.2003.

${ }^{102}$ Organização criada em 1961, com sede em Paris cuja missão é promover políticas que melhorem em todo o mundo bem-estar econômico e social, fornecendo aos governos um fórum onde possam trabalhar juntos, compartilhar experiências e buscar soluções para problemas comuns. Efetua medições de produtividade e dos fluxos globais de comércio e investimento, comparando os dados para prever tendências futuras, procurando estabelecer padrões internacionais em muitos campos, da agricultura à tributação por meio da segurança química, além de examinar o custo dos impostos e segurança social dos cidadãos e do tempo livre que eles têm, comparando a forma como os sistemas de educação preparam os alunos para a vida moderna e como sistemas de pensões protegem os cidadãos mais velhos, valendo-se de experiências concretas, recomendando políticas que visem melhorar a vida das pessoas comuns, além de se esforçar para tornar a vida mais difícil para os terroristas, evasores fiscais, empreiteiros corruptos e aqueles que minam as bases de uma sociedade justa e aberta, in: http://www.oecd.org/. - Acesso em 18.02.12
} 
dirigentes assegurar a legalidade, a eficiência, a relação custo-efetividade $e$ a regularidade da ação conduzida.". 103

Modernamente o enfoque se volta para além de um 'controle' dito burocrático, passando para um nível gerencial, como se além da verificação da formalidade de um processo, como a realização de licitação para construção de um hospital (burocracia) a administração pública voltasse os olhos para a satisfação do cidadão - no mesmo exemplo, se a população local está sendo bem atendida no quesito da saúde (gerenciamento das necessidades).

Este fenômeno que envolve novas concepções de gestão e programação governamental, com maior responsabilização dos dirigentes públicos pela gestão da coisa pública vem sendo verificado na Europa, onde é conhecido como aziendalizzazione da Administração Pública, no qual a função gerencial (manageriale) ganha força visando melhores análises técnicas e econômicas dos recursos à disposição do administrador público em prol da sociedade administrada ${ }^{104}$.

O mesmo avanço pode ser percebido no Brasil, conforme se verifica no texto da Lei $\mathrm{n}^{\circ} 4.320$ de 17 de março de 1964 (como o controle pelo resultado previsto no art. 75, III) e pela Lei Complementar $n^{\circ} 101$ de 04 de maio de 2000 e seus dispositivos de responsabilidade na gestão fiscal.

Assim, a vigilância sobre o Poder Público, no que tange à atividade financeira do Estado acontece por meio de fiscalização e esta se opera no controle. Ambos estão intimamente ligados à necessidade de prestação de contas.

\subsection{1 - A exigência de Prestação de Contas}

O princípio da prestação de contas ou o dever de prestar contas está consolidado na cultura moderna e sua origem remonta à própria gênese das civilizações. A

\footnotetext{
103 La modernization Du secteur public: modernizer la responsabilité et le controle. L'Observateur: Synthèses OCDE, p.2, jui.2005.

${ }^{104}$ CARDUCCI, Piero; SANTORUFO, Maria; ZINNO, Fulvia. La riforma dell'Amministrazione Pubblica e nuove formedi controllo nella Prefetture - Uffici Territoriali Del Governo. Instrumenta, n.22, a, VIII, p.7172, gen/apr. 2004.
} 
primeira notícia que se tem sobre o tema é a de documentos de índole contábil, sendo redigida em escrita cuneiforme há cerca de dois mil e seiscentos anos. Há registros na cultura helênica, criadora do conceito da res pública, da utilização desse instituto entre os administradores da democracia ateniense. Decisões tomadas em assembleias dos cidadãos atenienses eram executadas por mandatários, que após, prestavam contas à assembleia por meio de uma comissão que recebia as informações das contas, submetendo-as à aprovação do grupo maior.

Consta que o código jurídico indiano, o Manú, nos primórdios daquela civilização, já tratava do controle externo dos gastos do príncipe e existiam registros do dever de prestar contas na Roma Antiga, quando os magistrados romanos, que assumiam tais funções temporariamente deveriam prestar contas perante as assembleias de cidadãos ou diante do Senado, conforme o caso, antes de deixarem seus respectivos cargos (exercidos graciosamente) para retornarem à condição de simples cidadãos.

A própria Bíblia (Mateus 25.14) na Parábola dos Talentos refere que o senhor que havia distribuído os bens entre os seus servos quando de viagem, para que os administrassem, cobra deles no retorno as 'contas' dos dinheiros deixados, sendo que eles apresentam os rendimentos da 'gestão' e se justificam perante o senhor que as analisa, atribuindo uma sentença a cada qual conforme o resultado obtido ${ }^{105}$.

Modernamente, a Revolução Francesa como marco e a Declaração dos Direitos do Homem e do Cidadão de 1789, consagram o princípio da prestação de contas e o do controle. Consta no art. 15 da Declaração: "a sociedade tem o direito de pedir conta a todo agente público de sua administração”. Encontra-se no texto uma das fontes do sistema representativo no regime do Estado de Direito.

No Brasil, o pilar jurídico da prestação de contas se assenta na Constituição Federal, seja em seu preâmbulo, seja nos princípios fundamentais, seja pelos arts. 70 e 71:

O preâmbulo diz que "Nós, representantes do povo brasileiro, reunidos em Assembleia Nacional Constituinte para instituir um Estado Democrático, destinado a

\footnotetext{
${ }^{105}$ CHAVES, Francisco Eduardo Carrilho. Controle Externo da Gestão Pública. Niterói: Impetus, 2007. P.7
} 
assegurar o exercício dos direitos sociais e individuais, a liberdade, a segurança, o bemestar, o desenvolvimento, a igualdade e a justiça como valores supremos de uma sociedade fraterna, pluralista e sem preconceitos, fundada na harmonia social e comprometida, na ordem interna e internacional, com a solução pacífica das controvérsias, promulgamos, sob a proteção de Deus, a seguinte CONSTITUIÇÃO DA REPÚBLICA FEDERATIVA DO BRASIL.

E logo no início, trata dos princípios fundamentais, quando faz constar no art. 1": "A República Federativa do Brasil, formada pela união indissolúvel dos Estados e Municípios e do Distrito Federal, constitui-se em Estado Democrático de Direito e tem como fundamentos: I - a soberania; II - a cidadania; III - a dignidade da pessoa humana; $I V$ - os valores sociais do trabalho e da livre iniciativa; $V$ - o pluralismo político”. Indica o parágrafo único: "Todo o poder emana do povo, que o exerce por meio de representantes eleitos ou diretamente, nos termos desta Constituição”.

Assim, na medida em que a Constituição Federal diz que o poder será exercido em nome e em favor do povo, a atuação de quem detém o poder deve ser direcionada para atender ao interesse coletivo, respeitados os princípios apresentados na própria Carta Magna, inseridos ainda os temas da legalidade, legitimidade e economicidade (art.70) que serão adiante estudados.

Logo, se ungidos os administradores públicos de poder estatal, não podem se desviar na utilização de tal poder que ostentam, posto que o detém somente para atender o interesse público. Daí deriva a necessidade de prestar contas e serem fiscalizados.

Para Hely Lopes Meireles ${ }^{106}$ : “o dever de prestar contas é decorrência natural da administração como encargo de gestão de bens e interesses alheios. Se o administrador corresponde ao desempenho de um mandato de zelo e conservação de bens e interesses de outrem, manifesto é que quem o exerce deverá contas ao proprietário. No caso do administrador público, esse dever ainda mais se alteia porque a gestão se refere aos bens e interesses da coletividade e assume o caráter de um 'munus público', isto é, de um encargo para com a comunidade”.

${ }^{106}$ MEIRELLES, Hely Lopes. Direito Administrativo brasileiro. 26ª Ed.. São Paulo: Malheiros, 2001. 
E José Afonso da Silva indica ${ }^{107}$ que são chamados princípios sensíveis aqueles enumerados no art. 34 da Constituição Federal: “a) da forma republicana de governo; b) do sistema representativo e regime democrático; c) dos direitos da pessoa humana; d) da autonomia municipal; e) da prestação de contas da administração pública, direta e indireta"

Entretanto, mesmo tendo como lógico o princípio jurídico de que todo aquele que age em nome de alguém tem o dever de prestar contas, a normatização da Constituição Federal deve ser clara para evitar edição de normas inferiores causadoras de situações contraditórias ou qualquer outro tipo de dúvida sobre o tema.

Assim, o dever jurídico de prestar contas está elevado à categoria de norma constitucional, sendo que também fixa a Lei maior quem está sujeito a prestar contas e ser fiscalizado. Entretanto, há disciplina infraconstitucional que apresenta detalhamentos acerca da fiscalização a ser efetuada.

Todos os Poderes do Estado devem manter um sistema que esteja de acordo com suas características e ao mesmo tempo possa se integrar com os demais, visando coordenação e uniformização de comportamentos e providências.

Consoante art. 74 da Constituição Federal, os Poderes Legislativo e Judiciário devem: I - avaliar o cumprimento das metas previstas no plano plurianual, a execução dos programas de governo e dos orçamentos da União; II - comprovar a legalidade e avaliar os resultados, quanto à eficácia e eficiência, da gestão orçamentária, financeira e patrimonial nos órgãos e entidades da administração federal, bem como da aplicação de recursos públicos por entidades de direito privado; III - exercer o controle das operações de crédito, avais e garantias, bem como dos direitos e haveres da União; IV - apoiar o controle externo no exercício de sua missão institucional.

A Lei de Diretrizes Orçamentárias (Lei no 12.708 de 17 de agosto de 2012) prevê no art. 65 que as entidades públicas e privadas beneficiadas com recursos públicos a qualquer título estarão submetidas à fiscalização do Poder Público, com a finalidade de

${ }^{107}$ SILVA, José Afonso da. Curso de direito constitucional positivo. 27ª ed.São Paulo, Malheiros, 2006. 
verificar o cumprimento de metas e objetivos para os quais receberam os recursos. Indica no $\S 1^{\circ}$ que o Poder Executivo adotará providências com vistas ao registro e à divulgação, inclusive por meio eletrônico, das informações relativas às prestações de contas de convênios ou instrumentos congêneres e no $\S 2^{\circ}$ que no caso de contratação de terceiros pelo convenente ou beneficiário, as informações previstas no parágrafo $1^{\circ}$ conterão, no mínimo, nome e CPF ou CNPJ do fornecedor e valores pagos.

Portanto, o dever de prestar contas e a necessidade de fiscalização e controle dos atos da administração pública estão intimamente ligados.

\section{4 - Classificação do Controle}

Poderíamos referir distintas formas de se classificar o controle, como, por exemplo, pelo critério do Poder que o exerce, apontando para o controle administrativo ou executivo feito pela própria Administração sobre seus atos; legislativo ou parlamentar, feito pelo Poder Legislativo e Judiciário, realizado pelos juízes. Ou ainda, diante do momento da sua ocorrência, se antes, durante ou depois da realização e consumação do ato objeto do controle; ou mesmo com relação ao objeto controlado, se ato ou atividade.

Porém a classificação doutrinária mais aceita leva em consideração o órgão controlador e sua posição em relação àquele que é controlado, sendo subdividida em controle interno e controle externo (aqui entendido 'latu sensu', como será visto), sendo que a análise do ato será sempre feita independentemente da classificação adotada, servindo esta para efeitos didáticos de entendimento e ainda efeitos práticos de consecução dos trabalhos de fiscalização.

\subsection{1 - Controle Interno}

Controle interno é aquele exercido pelo sistema próprio de cada Poder (e aqui entenda-se também que o exercem o Tribunal de Contas e o Ministério Público, mediante mecanismos semelhantes aos utilizados pelos três Poderes da República). É obrigatória a existência de órgão de controle interno em todos os Poderes, considerados os distintos entes federativos, conforme art. 74 da Constituição Federal. 
Extrai-se do Acórdão no 1074 do Tribunal de Contas da União ${ }^{108}$ que controle interno conforme definição da Intosai ${ }^{109}$ : é "um processo integrado efetuado pela direção e corpo de funcionários, e é estruturado para enfrentar os riscos e fornecer razoável segurança de que na consecução da missão da entidade os seguintes objetivos gerais serão alcançados: execução ordenada, ética, econômica, eficiente e eficaz das operações; cumprimento das obrigações de 'accountability' ${ }^{110}$; cumprimento das leis e regulamentos aplicáveis; salvaguarda dos recursos para evitar perdas, mau uso e dano.”.

Os controles internos das entidades devem ser constantemente avaliados (portanto, também controlados) e tal avaliação é um processo mediante o qual se procura conhecer e avaliar sua eficácia quanto à capacidade para evitar ou reduzir o impacto ou a probabilidade da ocorrência de eventos de risco na execução de seus processos e atividades, que possam impedir ou dificultar o alcance de objetivos estabelecidos.

O patrimônio público, inserido nesta afirmação, será necessariamente objeto do controle.

\footnotetext{
${ }^{108}$ TCU - Rel. Min. Weder de Oliveira, DOU 22.05.2009

109 A Organização Internacional de Entidades Fiscalizadoras Superiores (Intosai, em inglês) foi fundada em 1953 por 34 países, entre eles o Brasil. Contava em agosto de 2008, com 188 membros. A "Declaração de Lima sobre Preceitos de Auditoria", adotada no Congresso Internacional de 1977 e reconhecida como a Magna Carta da auditoria governamental, fornece as bases filosóficas e conceituais dos trabalhos desenvolvidos pela Intosai. Os estatutos da organização, revisados e assinados no Congresso Internacional realizado em Washington em 1992, detalham a estrutura, as atribuições e as normas de funcionamento da organização que trabalha no sentido de promover o intercâmbio de informações e de experiências sobre os principais desafios enfrentados pelas EFS no desempenho de suas funções. Para atingir público alvo tão diversificado, a Intosai possui cinco idiomas oficiais: alemão, árabe,espanhol, francês e inglês. A Intosai cumpre suas atribuições e objetivos por meio de diversos órgãos, programas e atividades. Sua estrutura é composta pelo Congresso Internacional, Conselho Diretor, Secretaria Geral, Grupos de Trabalho Regionais e Comissões e Grupos de Trabalho sobre temas específicos. A área de treinamento engloba a promoção de Seminários Internacionais e cursos regionais voltados para a formação de instrutores sob a coordenação da Iniciativa para o Desenvolvimento da Intosai (IDI). Para subsidiar as atividades de controle externo desenvolvidas por seus membros, são publicados a Revista Internacional de Auditoria Governamental e os trabalhos dos diversos Grupos de Trabalho e Comissões da organização, que englobam diretrizes, guias metodológicos e pesquisas. O Tribunal de Contas da União é membro da Comitê de Normas Profissionais, do Grupo de Trabalho de Tecnologia da Informação, do Grupo de Trabalho de Auditoria Ambiental e do Grupo de Trabalho de Privatização, Regulação Econômica e PPP. Além disso, o Tribunal preside o Subcomitê de Auditoria de Desempenho, pertencente ao Comitê de Normas Profissionais. www.intosai.org. Acesso em 20.02.12.

${ }^{110}$ OBS - Accountability é um termo sem exata tradução para o português. Origina-se do termo latino accomptare (tomar em conta), derivado da forma prefixada computare (computar), que por sua vez deriva de putare (calcular). Traduz-se mais em um conceito da esfera ética válido para circunstâncias que denotam responsabilidade social, obrigações e prestação de contas. Importa em um aspecto central de governança, tanto na esfera pública como na vida privada, guardando nexo com 'responsabilidade'.
} 
É dever intrínseco à atividade da auditoria interna a avaliação para melhoria da eficácia dos sistemas de controles internos da organização.

3.4.1.1 - Momento prévio, concomitante e subsequente.

O controle interno pode ser: prévio, concomitante e subseqüente, quanto à legalidade dos atos praticados, o que se encontra moldado no art.77 da Lei 4.320/64 ${ }^{111}$, sendo que não necessariamente se limita aos atos de execução orçamentária (como ali mencionado), mas devendo acontecer em todo o âmbito da administração pública em sua total complexidade de realização de atos (extraindo-se hipóteses em legislações próprias citando-se como exemplo o controle prévio de Editais pelo Tribunal de Contas, resultando na proteção do patrimônio público, dentre outros escopos da administração pública).

O Prévio, dependendo da situação, poderá a legislação estabelecer sobre quais atos irá recair a fiscalização (como no exemplo mencionado do Edital). O controle Concomitante acontece durante a realização da despesa ou do ato (este, se em caráter diferido no tempo, visto que se uma vez instantâneo seria difícil o controle simultâneo à sua execução) e o Subsequente permite saber a que se destinou a despesa e qual seu fundamento legal, bem como se o ato praticado atendeu a todos os requisitos referentes à legalidade e aos demais parâmetros previsto para sua existência no mundo jurídico.

Basicamente pensa-se em movimentações financeiras, mas o sistema se aplica também à questão patrimonial na medida em que os impactos financeiros guardem nexo com o patrimônio público (pontuando-se que adiante será vista classificação para distintas versões de 'patrimônio público').

Sem prejuízo de que a qualquer momento possa acontecer 'levantamento, prestação ou tomada de contas de todos os responsáveis por bens ou valores públicos' conforme a parte final do art. 78 da Lei 4.320/64, lei esta que, ainda, quando se refere ao controle interno, aponta que o Poder Executivo exercerá os três tipos de controle mencionados, sem excepcionar as atribuições do Tribunal de Contas ou órgão equivalente (art. 76).

${ }^{111}$ Art. 77. A verificação da legalidade dos atos de execução orçamentária será prévia, concomitante e subsequente. 
Ao órgão incumbido da elaboração da proposta orçamentária ou a outro indicado na legislação, caberá o controle do cumprimento do programa de trabalho expresso em termos monetários e em termos de realização de obras e prestação de serviços (art. 79.) e será feito, quando for o caso, em termos de unidades de medida, previamente estabelecidos para cada atividade.

Competirá, então, aos serviços de contabilidade ou órgãos equivalentes verificar a exata observância dos limites das cotas trimestrais atribuídas a cada unidade orçamentária, dentro do sistema que for instituído para esse fim (art. 80).

As diversas funções exercidas pelo controle interno devem constituir e compor um todo coerente e organizado permitindo a integração das atividades, sendo considerado um "processo com diversas facetas"112 ainda que com complexidade permissiva de desdobramentos em vários processos de controle.

A administração pública federal possui sistema disciplinado de controle interno, conforme Lei $\mathrm{n}^{\circ} 10.180$ de 2001, que no art. 22 prevê a subdivisão em órgãos, como um órgão central, outros setoriais, unidades setoriais e unidades regionais do órgão central, com as respectivas competências e atribuições apontando para o mencionado desdobramento, porém com a unidade e coerência respeitadas.

3.4.1.2 - Objetivos, estruturação e conteúdo do controle interno.

Evandro Martins Guerra ${ }^{113}$ menciona que em decorrência das previsões dos artigos 74 e 75 da Constituição Federal, é possível traçar como objetivos gerais do controle interno o seguinte: "1 - atuar de forma preventiva, detectando desvios, fraudes ou situações antieconômicas, abuso de poder, dentre outras práticas ilícitas; 2 - garantir a promoção de operações econômicas, eficientes e eficazes, além da qualidade dos serviços prestados pelo órgão ou entidade, de acordo com o interesse público;3 - fiscalizar a obediência às leis, normas e princípios norteadores da Administração; 4 - garantir a

\footnotetext{
${ }^{112}$ DEROZA, Maria de Lourdes. Controles Internos: aspectos gerais da avaliação dos controles de gastos precedidos de licitação. Monografia - TCU, Brasilia, 2004, p.17

${ }_{113}$ GUERRA, Evandro Martins. Os controles externo e interno da Administração Publica. Belo Horizonte, ed. Forum. 2005, p.275
} 
aplicação do ativo e a legitimidade do passivo; 5 - propiciar a criação de mecanismos asseguradores da exatidão, da confiabilidade, da integridade dos dados contáveis e dos relatórios financeiros gerenciais".

O controle interno também deve ser desenvolvido conforme normas já existentes, sendo que diversas foram estruturadas a partir de experimentos e orientações oriundos de entidades fiscalizadoras internacionais, tais como a INTOSAI (Organização Internacional de Entidades Fiscalizadoras Superiores), que apresenta em trabalho de 1992 (Guia para Normas de Controle Interno) ${ }^{114}$ elenco de regras para a estruturação do controle interno, sendo possível destacar algumas:

.segurança razoável, tida como um nível mínimo satisfatório de confiabilidade, relativamente aos riscos inerentes, ao custo necessário e aos benefícios desejados;

atitude cooperativa, isto é, a necessária cooperação e apoio entre os envolvidos na ação da gerência administrativa;

.integridade e competência, características necessárias àqueles que exercem o controle, como forma de garantia do seu desenvolvimento eficaz e da consecução dos objetivos gerais desejados;

.objetivos do controle, ou seja, os escopos específicos, buscados pelos procedimentos, devem ser identificados explicitamente para cada setor administrativo, de maneira clara e apropriada, integrada aos objetivos gerais pretendidos;

.acompanhamento dos controles, de forma contínua e concomitante, almejando-se, destarte, a apuração imediata dos desvios porventura existentes e consequente saneamento dos mesmos.

${ }_{114}^{114}$ GUERRA, Evandro Martins. Os controles externo e interno da Administração Publica. Belo Horizonte, ed. Forum. 2005, p.276. 
Destacam-se no mesmo estudo normas específicas, vale dizer, aquelas relativas aos procedimentos e planos administrativos de controle:

- documentação e registro - todos os atos do controle devem ser devidamente registrados, documentados e arquivados para posterior consulta;

.autorização e execução - os atos devem ser autorizados e executados por aqueles que detém competência para tal, sob pena de nulidade;

.segregação das funções - as várias funções inerentes aos procedimentos, como autorização, processamento, revisão e registro, devem ser cumpridas por agentes diversos;

. supervisão - entende-se fundamental que os mecanismos desenvolvidos sejam acompanhados por uma supervisão, garantindo-se, assim, a consecução dos objetivos pretendidos pelo sistema de controle interno;

.acesso aos registros - a possibilidade de consulta e análise dos dados registrados deve ser limitada às pessoas autorizadas para tal, a quem compete fazer a comparação entre o que foi planejado anteriormente e os resultados alcançados.

Há ainda, instrumentos determinados, mecanismos e procedimentos, que propiciam à Administração Pública alcançar os objetivos previstos, como: quadro de pessoal (em todos os níveis profissionais), políticas organizacionais (específicas e definidas de forma expressa, por publicação própria e divulgação respectiva, periodicamente revistas e remanejadas), normas de procedimentos de qualidade $e$ avaliação (com publicidade para toda a Administração), manual de procedimentos (elaborado de modo simples, com informações sobre as ações mais eficientes e econômicas, incluindo revisão de tarefas por agentes que não tenham participado da execução original), rotinas internas (formulários com instruções para preenchimento e distribuição, sistema de autorização de transações e operações, chancela do responsável pelos procedimentos, evidenciando-se a execução), relatórios internos (a partir das 
competências definidas para cada agente, sempre o mais simples possível), responsabilidade (definida expressamente e divulgada via manuais), integração do sistema (permitindo fluxo de realização de tarefas onde um setor possa ser controlado por outro).

As formas de controle interno devem conter conteúdos específicos de acordo com a relevância de cada área de atuação, respeitadas as peculiaridades de cada setor, ente ou órgão controlado.

Guerra $^{115}$ enumera, ainda, algumas que considera mais relevantes, a saber: autorização, comparação, numeração sequencial, controle de totais, operações pendentes, anotações, dupla verificação, controle prévio, segregação de tarefas, acesso restrito, supervisão e auditoria interna, indicando ainda que deve ser implementado o controle interno através de etapas lógicas preestabelecidas, sequenciadas e ordenadas, tais como detalhamento de todas as funções administrativas, avaliação do grau de vulnerabilidade da Administração frente a desperdícios, utilização não autorizada ou apropriação indevida (potencial de risco), verificação de eficácia e eficiência do controle estabelecido e confecção de relatório contendo deficiências apuradas e a segurança proporcionada.

Refere a importância da avaliação e que deve, necessariamente, ser realizada por meio de questionários contendo questões específicas de cada setor, descrições com narrativa de todos os mecanismos de controle e dos resultados alcançados e fluxogramas com demonstração condensada em gráficos dos resultados obtidos pelo sistema.

\subsubsection{3 - Controladoria Geral da União (CGU) e Advocacia Geral da União (AGU).}

O principal órgão de controle interno da Administração Pública Federal é a Controladoria-Geral da União (CGU), sendo suas atribuições definidas pela Lei ${ }^{\circ} 10.683$ de 28 de maio de 2003.

Compete ao órgão assistir direta e imediatamente ao Presidente da República no desempenho de suas atribuições quanto aos assuntos e providências que, no âmbito do Poder Executivo, sejam atinentes à defesa do patrimônio público, ao controle

${ }_{115}$ GUERRA, Evandro Martins. Os controles externo e interno da Administração Publica. Belo Horizonte, ed. Forum. 2005, p.278 
interno, à auditoria pública, à correição, à prevenção e ao combate à corrupção, às atividades de ouvidoria e ao incremento da transparência da gestão no âmbito da administração pública federal.

Seu titular é o Ministro de Estado Chefe da Controladoria-Geral da União, e sua estrutura básica é constituída por: Gabinete, Assessoria Jurídica, Conselho de Transparência Pública e Combate à Corrupção, Comissão de Coordenação de Controle Interno, Secretaria-Executiva, Corregedoria-Geral da União, Ouvidoria-Geral da União e duas Secretarias, sendo uma a Secretaria Federal de Controle Interno.

À Controladoria-Geral da União, no exercício de sua competência, cabe dar o devido andamento às representações ou denúncias fundamentadas que receber, relativas a lesão ou ameaça de lesão ao patrimônio público, velando por seu integral deslinde.

Sempre que constatar omissão da autoridade competente, cumpre requisitar a instauração de sindicância, procedimentos e processos administrativos outros, e avocar aqueles já em curso em órgão ou entidade da Administração Pública Federal, para corrigirlhes o andamento, inclusive promovendo a aplicação da penalidade administrativa cabível, devendo ainda instaurar sindicância ou processo administrativo ou, conforme o caso, representar ao Presidente da República para apurar a omissão das autoridades responsáveis.

A CGU deverá também encaminhar à Advocacia-Geral da União os casos que configurem improbidade administrativa e todos quantos recomendem a indisponibilidade de bens, o ressarcimento ao erário e outras providências a cargo daquele órgão, bem como provocará, sempre que necessária, a atuação do Tribunal de Contas da União, da Secretaria da Receita Federal, dos órgãos do Sistema de Controle Interno do Poder Executivo Federal e, quando houver indícios de responsabilidade penal, do Departamento de Polícia Federal e do Ministério Público, inclusive quanto a representações ou denúncias que se afigurarem manifestamente caluniosas.

Incluem-se dentre os procedimentos e processos administrativos de instauração e avocação facultadas à Controladoria-Geral da União aqueles objeto do Título $\mathrm{V}$ da Lei $\mathrm{n}^{\mathrm{o}}$ 8.112, de 11 de dezembro de 1990 (regime administrativo dos servidores públicos e respectivo processo disciplinar) e do Capítulo V da Lei $\mathrm{n}^{0} 8.429$, de 2 de junho 
de 1992 (Lei de Improbidade Administrativa e respectiva previsão do procedimento administrativo e do processo judicial), assim como outros a ser desenvolvidos, ou já em curso, em órgão ou entidade da Administração Pública Federal, desde que relacionados a lesão ou ameaça de lesão ao patrimônio público.

Ao Ministro de Estado Chefe da Controladoria-Geral da União, no exercício da sua competência, incumbe, especialmente decidir, preliminarmente, sobre as representações ou denúncias fundamentadas que receber, indicando as providências cabíveis; instaurar os procedimentos e processos administrativos a seu cargo, constituindo as respectivas comissões, bem como requisitar a instauração daqueles que venham sendo injustificadamente retardados pela autoridade responsável; acompanhar procedimentos e processos administrativos em curso em órgãos ou entidades da Administração Pública Federal; realizar inspeções e avocar procedimentos e processos em curso na Administração Pública Federal, para exame de sua regularidade, propondo a adoção de providências, ou a correção de falhas; efetivar, ou promover, a declaração da nulidade de procedimento ou processo administrativo, bem como, se for o caso, a imediata e regular apuração dos fatos envolvidos nos autos, e na nulidade declarada; requisitar procedimentos e processos administrativos já arquivados por autoridade da Administração Pública Federal; requisitar, a órgão ou entidade da Administração Pública Federal ou, quando for o caso, propor ao Presidente da República que sejam solicitadas, as informações e os documentos necessários a trabalhos da Controladoria-Geral da União.

Também requisitar aos órgãos e às entidades federais os servidores e empregados necessários à constituição das comissões que irão acompanhar os procedimentos ou processos administrativos, bem como qualquer servidor ou empregado indispensável à instrução do processo; propor medidas legislativas ou administrativas e sugerir ações necessárias a evitar a repetição de irregularidades constatadas; receber as reclamações relativas à prestação de serviços públicos em geral e promover a apuração do exercício negligente de cargo, emprego ou função na Administração Pública Federal, quando não houver disposição legal que atribua competências específicas a outros órgãos; e finalmente desenvolver outras atribuições de que o incumba o Presidente da República.

Os titulares dos órgãos do Sistema de Controle Interno do Poder Executivo federal devem cientificar o Ministro de Estado Chefe da Controladoria-Geral da União das 
irregularidades verificadas, e registradas em seus relatórios, atinentes a atos ou fatos, atribuíveis a agentes da administração pública federal, dos quais haja resultado, ou possa resultar, prejuízo ao erário, de valor superior ao limite fixado pelo Tribunal de Contas da União, relativamente à tomada de contas especial elaborada de forma simplificada.

As requisições de pessoal, inclusive de técnicos feitas pelo Ministro de Estado Chefe da Controladoria-Geral da União, serão irrecusáveis e deverão ser prontamente atendidas, enquanto que os órgãos e as entidades da administração pública federal estão obrigados a atender, no prazo por ele indicado, às demais requisições e solicitações, bem como a comunicar-lhe a instauração de sindicância, ou outro processo administrativo, e o respectivo resultado.

Via de regra, o fluxograma do procedimento para apuração da CGU se inicia com uma denúncia ou comunicação por qualquer pessoa de algum fato a ser investigado, ou mesmo de ofício, se porventura o próprio auditor dele toma conhecimento. A seguir procede-se a um levantamento de informações com apresentação de uma nota ao responsável que poderá prestar esclarecimentos. Após será feito um relatório e elaborado um parecer com o respectivo encaminhamento aos demais órgãos (Tribunal de Contas, Advocacia Geral, Ministério Público, Policia etc.) para providências, se for o caso.

No âmbito da Controladoria Geral da União foi criado o 'Conselho de Transparência Pública e Combate à Corrupção' cujas competências são ${ }^{116}$ : contribuir para a formulação das diretrizes da política de transparência da gestão de recursos públicos e de combate à corrupção e à impunidade, a ser implementada pela Controladoria-Geral da União e pelos demais órgãos e entidades da administração pública federal; sugerir projetos e ações prioritárias da política de transparência da gestão de recursos públicos e de combate à corrupção e à impunidade; sugerir procedimentos que promovam o aperfeiçoamento e a integração das ações de incremento da transparência e de combate à corrupção e à impunidade, no âmbito da administração pública federal; atuar como instância de articulação e mobilização da sociedade civil organizada para o combate à corrupção e à impunidade e realizar estudos e estabelecer estratégias que fundamentem

${ }^{116}$ http://www.cgu.gov.br/ConselhoTransparencia/Competencias.asp - Acesso em 08 de agosto de 2012 
propostas legislativas e administrativas tendentes a maximizar a transparência da gestão pública e ao combate à corrupção e à impunidade.

Compõe o Conselho o Ministro de Estado do Controle e da Transparência (seu presidente), representantes da Casa Civil da Presidência da República, da AdvocaciaGeral da União, do Ministério da Justiça, do Ministério da Fazenda, do Ministério do Planejamento, Orçamento e Gestão, do Ministério das Relações Exteriores, da Comissão de Ética Pública da Presidência da República, do Ministério Público da União, do Tribunal de Contas da União, da Ordem dos Advogados do Brasil, da Associação Brasileira de Imprensa, da organização Transparência Brasil, da Associação Brasileira de Organizações Não-Governamentais, da Conferência Nacional dos Bispos do Brasil, por um representante indicado pelas igrejas evangélicas de âmbito nacional, organizadas segundo suas convenções, concílios gerais ou sínodos, outro dos Trabalhadores indicado pela UniãoGeral dos Trabalhadores, outro dos Empregadores indicado pela Confederação Nacional das Instituições Financeiras, um cidadão brasileiro com atuação notória e o Instituto Ethos de Empresas e Responsabilidade Social;

Os representantes dos órgãos nãogovernamentais terão mandato de dois anos, permitida uma recondução por igual período.

Observa-se no tema do controle interno a evolução no sentido de se permitir a participação direta da sociedade, ainda que de forma tênue, por meio de representantes diretamente indicados e com atribuições em especial na política de transparência.

A Controladoria-Geral da União pode, ainda, fiscalizar recursos repassados a outros entes distintos da União. Conforme decidido pelo STJ no Mandado de Segurança n. 9642 - DF, a Controladoria-Geral da União tem atribuição para fiscalizar a aplicação dos recursos federais repassados aos Municípios, sem que isto implique em quebra da autonomia dos entes federados, tendo em vista que fiscalização não incide sobre recursos estaduais ou municipais, mas exclusivamente sobre verbas provenientes do orçamento da União.

À evidencia, o questionamento partiu do Município fiscalizado (Itagimirim), que não concordou com a intervenção da Controladoria (CGU). O STJ afirma na decisão 
que o art. 17 da Lei n. 10.683/02 que dispõe sobre a organização da Presidência da Republica e dos Ministérios garante à Controladoria-Geral da União tal possibilidade. Indica que consectário daquele poder-dever é que os auditores da Secretaria Federal de Controle Interno examinem as contas e documentos e façam inspeção pessoal e física das obras e serviços executados a partir de recursos transferidos pelo Poder Público Federal. Assim, para o caso concreto, enquanto à CGU competiria o controle interno, ao TCU caberia o controle externo.

No mesmo sentido já decidiu o $\mathrm{STF}^{117}$ : "A Controladoria-Geral da União (CGU) pode fiscalizar a aplicação de verbas federais onde quer que elas estejam sendo aplicadas, mesmo que em outro ente federado às quais foram destinadas. A fiscalização exercida pela CGU é interna, pois feita exclusivamente sobre verbas provenientes do orçamento do Executivo.".

O tópico é positivo, posto que no tema da fiscalização patrimonial a interpretação quando de divergências deve ser, sempre que possível, a que menor restrição apresentar. Assim, sem ofender o princípio federativo, apresenta o Poder Judiciário a possibilidade do maior espectro acerca do controle dos órgaõs diante do patrimônio público.

A Advocacia Geral da União, por seu turno, conforme a Lei $n^{\circ} 10.683$ de 28 de maio de 2003, pelos artigos. $1^{\circ}$, $\$ 2^{\circ}$, VI e 12 também é considerado órgão de controle interno e ao Advogado-Geral da União, o mais elevado órgão de assessoramento jurídico do Poder Executivo, incumbe assessorar o Presidente da República em assuntos de natureza jurídica, elaborando pareceres e estudos ou propondo normas, medidas, diretrizes, assistir-lhe no controle interno da legalidade dos atos da Administração Pública Federal, sugerir-lhe medidas de caráter jurídico reclamadas pelo interesse público e apresentar-lhe as informações a ser prestadas ao Poder Judiciário quando impugnado ato ou omissão presidencial, dentre outras atribuições fixadas na Lei Complementar $n^{\circ} 73$, de 10 de fevereiro de 1993.

${ }^{117}$ RMS 25.943, Rel. Min. Ricardo Lewandovski, julgamento em 24-11-2010, Plenário, DJE de 2-3-2011. 


\subsubsection{4 - Autocontrole.}

Existe ainda o chamado 'autocontrole', por assim dizer, o que se pode extrair do texto da Súmula 473 do Supremo Tribunal Federal: "A administração pode anular seus próprios atos quando eivados de vícios que os tornam ilegais, porque deles não se originam direitos, ou revogá-los por motivo de conveniência ou oportunidade, respeitados os direitos adquiridos e ressalvada em todos os casos, a apreciação judicial”.

Neste caso, acontece a fiscalização pela própria autoridade que editou o ato, ou responsável pela atividade sobre sua atuação e pode ser de forma espontânea ou por provocação (por exemplo, um recurso administrativo, ou pedido de reconsideração ou ainda uma reclamação ou abaixo assinado).

Ainda que o autocontrole possa parecer coincidente com o controle interno, cabe referir que há diferença entre eles. $\mathrm{O}$ controle interno se ocupa das modalidades previstas nos referido art. 70 da Constituição Federal, mais voltado para a questão financeira e patrimonial, enquanto que o autocontrole tem escopo administrativo, diante de sua íntima ligação com o poder de revisão dos atos emitidos pela Administração Pública, embora ambos possam ter a mesma natureza quanto ao resultado global, a saber, a obtenção do melhor resultado em prol dos administrados e também causarem, respectivamente, impactos no patrimônio público.

\subsubsection{5 - Controle hierárquico.}

Há que se referir, também, a existência do controle hierárquico, que é a "verificação que os órgãos superiores realizam sobre os atos e atividades dos órgãos subordinados". 118 .

É possível notar grau de hierarquia quando se manifesta controle de atividade administrativa, na medida em que um órgão superior fiscaliza um inferior, enquanto que na atividade exercida pelos órgãos de controle interno nem sempre existe relação de subordinação, mas sim uma instância do mesmo ambiente estatal com

\footnotetext{
${ }^{118}$ MEDAUAR, Odete, Controles internos da Administração Pública. Boletim de Direito Administrativo, $\mathrm{n}^{\circ}$ 06, p.366, 1992
} 
capacidade para monitorar e controlar os atos administrativos deste mesmo ambiente, guardando característica de órgão permanente dotado de independência funcional ${ }^{119}$.

O controle hierárquico faz com que exista concomitância de determinadas responsabilidades (admitindo mesmo imputação de culpa in vigilando), ainda que sem a mesma concomitância para o exercício da atividade em si, o que leva a uma maior atenção por parte do superior diante das atividades do subordinado.

Entretanto, por outro lado, é de se observar que, por maior independência que o controle interno tenha, a vinculação hierárquica a um administrador principal é fator que, por vezes pode apresentar algum óbice a um trabalho de maior extensão, diante da evidente inibição do agente em determinadas circunstâncias. Vale dizer que ao mesmo tempo em que a hierarquia serve para que servidores ou órgãos tenham maior cautela no exercício do processo fiscalizatório (diante da responsabilidade coletivizada), pode também atuar como agente inibidor de outros processos de fiscalização (pulverizando-se a responsabilidade, permitindo a ocultação de dados sensíveis).

\subsubsection{6 - Conclusão sobre o Controle Interno.}

Assim, a fiscalização do controle externo (que será vista adiante) pode apresentar maior independência, sendo que irá se valer, certamente, do trabalho desenvolvido pela auditoria interna. Um bom desempenho do sistema do controle interno serve para ajustar a eficiência dos controles de gestão empreendidos pelo Administrador.

Não se pode deixar de mencionar que o controle interno irá funcionar mais adequadamente se existir ação sinérgica entre os elementos que o compõe e neste sentido o sistema também exige - respeitadas atribuições e nomenclaturas distintas para diferentes unidades administrativas - ente com escopo de ouvir o cidadão ou os próprios membros da administração (Ouvidorias) para unir esforços às auditorias e corregedorias (estes, considerados outros instrumentos para a consecução dos objetivos de fiscalização sob a ótica interna).

${ }^{119}$ CARTES, Juan Eduardo Toledo. El control interno de La administracion: modernización de lós sistemas como uma emergencia. VIII Congresso Internacional de CLAD sobre La reforma Del Estado y de la Administracion Pública, Panamá, 28-31 oct.2003, p.4 
O administrador público responsável jamais poderá se opor à realização dos procedimentos de controle interno, sejam auditorias, correições ou outros, visto que deve dar o devido valor à verificação das irregularidades dos atos praticados pelos diversos agentes e gestores da coisa e do patrimônio público. Assim também deverá atender às recomendações feitas para melhoria das atividades e dos próprios mecanismos de controles, se detectadas falhas.

No Estado de São Paulo, cada órgão, municipal e estadual, deve comunicar ao Tribunal de Contas do Estado, quem é o responsável pelo seu controle interno e tal responsável fica obrigado a comunicar ao Tribunal de Contas qualquer situação de irregularidade encontrada no âmbito de seu órgão e da qual tome conhecimento, bem assim, as providências que adotou para saná-la ${ }^{120}$, sendo que a criação de algum órgão estadual semelhante à Controladoria Geral da União poderia contribuir para a melhora do sistema de controle interno da unidade da federação, diante da possibilidade de unificar sistemas e diretrizes.

Finalmente, em algumas situações práticas determinados órgãos de controle podem se sobrepor, restando que em hipóteses de apuração e conclusão semelhante venham a somar informações, porém se as conclusões forem distintas com divergências em especial nos quesitos da orientação e punição, óbices poderão acontecer em detrimento do bom andamento dos trabalhos junto ao ente fiscalizado. Assim, poderá ser exigindo, por vezes, intervenção de um terceiro (superior administrativo ou até mesmo o Poder Judiciário) para solucionar eventual impasse.

\subsection{2 - Controle Externo}

Já o controle externo, apesar de certa divergência doutrinária é aquele exercido por outro Poder ou órgão, diverso ou estranho à estrutura daquele que é controlado (e esta seria a divergência, na medida em que pode se considerar que está acontecendo ingerência de um Poder em outro, o que violaria a independência entre eles).

\footnotetext{
${ }^{120}$ CITADINI, Antonio Roque. Fiscalização da Administração Pública. Palestra proferida na Escola Paulista da Magistratura em 23 de fevereiro de 2005. P.3/20. Disponível em www.citadini.com.br. Acesso em 13.06.12
} 
Abrange o controle parlamentar direto, realizado pelo Poder Legislativo e ainda com auxílio ${ }^{121}$ do Tribunal de Contas, cujo rol de atribuições encontra-se no art.71 da Constituição Federal, estudado no capítulo específico do Tribunal de Contas, mais adiante, além do controle jurisdicional, feito pelo Poder Judiciário, via de regra, por provocação do Ministério Público nas questões coletivas e referentes à Administração Pública, por entidades de caráter coletivo e social ou ainda outros órgãos como Defensoria Pública, Advocacia Geral da União e similares ${ }^{122}$.

Também a Lei $\mathrm{n}^{\circ}$ 4.320/64 apresenta determinação acerca do controle externo. Os artigos 81 e 82 determinam que "O contrôle da execução orçamentária, pelo Poder Legislativo, terá por objetivo verificar a probidade da administração, a guarda e legal emprêgo dos dinheiros públicos e o cumprimento da Lei de Orçamento.".

Verifica-se aqui, quando da referência à 'probidade' a necessidade de se referir a Lei de Improbidade Administrativa (já estudada). Quando se fala do dever de probidade que é exigido do administrador, o tema se relaciona com honestidade e eficiência funcional mínima.

Neste sentido, consta que o Poder Executivo, anualmente, prestará contas ao Poder Legislativo, no prazo estabelecido nas Constituições ou nas Leis Orgânicas dos Municípios, quando então suas contas serão submetidas ao Poder Legislativo, com Parecer prévio do Tribunal de Contas ou órgão equivalente e se no Município não houver Tribunal de Contas ou órgão equivalente, a Câmara de Vereadores poderá designar peritos contadores para verificarem as contas do prefeito e sobre elas emitirem parecer.

\footnotetext{
${ }^{121}$ Expressão que recebe críticas, na medida em que, na prática os Tribunais de Contas tem natureza de órgão constitucional autônomo, exercendo o controle externo ao lado do Poder Legislativo, uma vez que não integram a estrutura formal, orgânica, do Poder e o 'auxílio' não permite que se observe a real extensão da forma de atuar dos Tribunais. O tema dos Tribunais de Contas é objeto de abordagem específica, em Capítulo próprio, no presente trabalho.

${ }^{122}$ Afirma-se, portanto, que o controle externo vai além daquele exercido somente pelo Poder Legislativo com auxílio do Tribunal de Contas. Considera-se que há amplitude ainda maior, podendo ser assim chamado latu sensu, em especial porque não trata apenas de questões orçamentárias, mas de outras incluindo as patrimoniais, sem excluir aquelas.
} 
3.4.2.1 - Controle Externo direto exercido pelo Poder Executivo.

Edmir Netto de Araújo ${ }^{123}$ lembrando lições de Maria Sylvia Zanella Di Pietro $^{124}$ e Celso Antonio Bandeira de Mello ${ }^{125}$ refere sete básicas ações que detém o Poder Legislativo para controle externo direto. Vejamo-nas:

. Determinados atos do Poder Executivo, como concessão de emissoras de televisão, escolha de 2/3 dos Ministros do Tribunal de Contas da União, pesquisa e lavra de recursos minerais, alienação e concessão de terras públicas de mais de 2.500 hectares e ainda outros conforme a $\mathrm{CF}$ (por exemplo, art. 49, XIV - aprovar iniciativas do Poder Executivo referentes a atividades nucleares), exigem do Congresso em geral e do Senado em particular aprovação ou autorização prévia ou posterior, que são editadas por decreto legislativo ou resolução;

. A convocação de Ministro de Estado por qualquer das Casas do Congresso ou de suas Comissões para prestar informações ou declarações, exige atendimento pessoal, sob pena de crime de responsabilidade, se injustificada a ausência. Entretanto as informações a serem prestadas exigem que o assunto seja previamente determinado. Também podem ser encaminhados pedidos de informações com prazo de trinta dias e o Congresso (por suas Casas ou Comissões) receber petições, reclamações, representações ou queixas de qualquer pessoa contra atos ou omissões de autoridades $(\mathrm{CF}$, art. $58, \S 2^{\circ}, \mathrm{IV}$ ) ou solicitar depoimento de qualquer autoridade ou cidadão (art. $58, \mathrm{~V})$.

- As Comissões Parlamentares de Inquérito (CPIs) tem poderes de investigação próprios de autoridades judiciais e podem ser criadas pelo Senado e pela Câmara em separado ou de forma conjunta, não detendo poder sancionador, atuando na investigação de irregularidades e encaminhando ao Ministério Público ou outra autoridade competente o que

\footnotetext{
${ }^{123}$ ARAÚJO, Edmir Netto de Curso de Direito Administrativo, $5^{\text {a }}$ Ed. São Paulo: Saraiva, 2010.p.1203

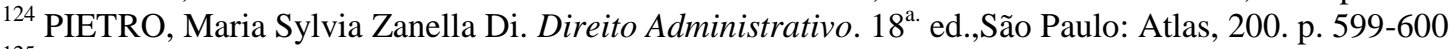

${ }^{125}$ MELLO, Celso Antonio Bandeira de. Curso de Direito Administrativo. $4^{\mathrm{a}}$ ed. São Paulo: Malheiros, 1993. p. $207-210$
} 
foi apurado, visando as respectivas medidas cabíveis sejam penais, administrativas ou patrimoniais.

. Pode o Congresso Nacional sustar contratos eivados de nulidade (a pedido do Tribunal de Contas $-\mathrm{CF}$, art. $71, \S 1^{\circ}$ ) e também sustar atos normativos do Poder Executivo que exorbitem do poder regulamentar ou dos limites de delegação legislativa (CF - art. 49, V), independente do Poder Judiciário.

. O Congresso Nacional detém competência para julgar anualmente as contas prestadas pelo Presidente da República e os relatórios sobre a execução dos planos governamentais (CF - art. 49, IX).

. O Senado possui competências privativas de controle, tais como aprovar escolhas de magistrados, de Ministros do Tribunal de Contas da União (indicados pelo Chefe do Poder Executivo), diretores do Banco Central, o Procurador-Geral da República (e também para destituí-lo), dos chefes de missões diplomáticas. Também detém competências financeiroorcamentárias, como fixar o limite global do montante da dívida mobiliária e consolidada da União, Estados, Distrito Federal e Municípios; estabelecer os limites globais e condições para operações de crédito externo e interno das unidades federativas, inclusive autarquias e outras entidades controladas pelo Poder Público, além de fixar limites e condições para a concessão de garantia em operações de crédito externo e interno ( $\mathrm{CF}$ - art. 52, VI/VIII). Tais atividades de controle estão disciplinadas na Lei Complementar $n^{\circ}$ 101/2000 (Lei de Responsabilidade Fiscal) e Lei n ${ }^{\circ}$ 10.028/2000 (Crimes contra as Finanças Públicas).

- Ao Senado compete processar e julgar por crimes de responsabilidade, o Presidente da República, o Vice-presidente, Ministros de Estado, Ministros do Supremo Tribunal Federal, o Procurador-Geral da República, e o Advogado-Geral da União, (sob a presidência do Presidente do STF, limitando-se a condenação por $2 / 3$ dos votos à perda do cargo, com inabilitação por oito anos para funções públicas). 
Diversas são as referências que configuram os contornos do controle externo e importa referi-las ainda que muitas delas estejam além do tema específico referente à questão do patrimônio público, porém seu conhecimento implica em reconhecer que assim como o estudo da fiscalização patrimonial da administração pública a análise das demais vertentes da fiscalização enriquece a possibilidade da sociedade ter para si o melhor que pode extrair do poder público.

\subsubsection{1 - Crimes de Responsabilidade.}

Em acontecendo crimes de responsabilidade que atentem contra a própria Constituição ou a existência da União, o livre exercício dos Poderes e Ministério Público, o exercício dos direitos políticos, individuais ou sociais, segurança interna do país, probidade na Administração, lei orçamentária, cumprimento das leis e decisões judiciais e houver relatório da CPI com pedido de impedimento (arts. 85 e 96 da CF) em sendo aprovado por 2/3 dos membros da Câmara, o Senado irá julgar o Presidente ou Ministro, suspendendo-o de imediato das funções e em caso de condenação destituí-los do cargo (impeachment) declarando o impedimento e deflagrando (se Presidente) a sucessão ${ }^{126}$.

\subsubsection{2 - Sustação de Ato Normativo.}

O Poder Executivo detém atribuição normativa para regulamentação de leis emanadas pelo Legislativo, principalmente por meio de decretos, portarias, instruções normativas e resoluções, além daquelas referentes à medida provisória e lei delegada. Aqueles atos normativos não podem criar direitos ou obrigações para o cidadão, mas tão somente definir as formas e os parâmetros para o exercício dos direitos e para o cumprimento das obrigações, previamente estabelecidos na lei ${ }^{127}$. Pode, então, o Congresso sustar tais atos normativos se exorbitarem o poder regulamentar ou os limites da delegação legislativa (art. 49, $\mathrm{V}$ da $\mathrm{CF}$ ).

\footnotetext{
${ }^{126}$ CRETELLA JR, José. Do impeachment no direito brasileiro, São Paulo: RT, 1992, p.62-64.

${ }^{127}$ CHAVES, Francisco Eduardo Carrilho. Controle Externo da Gestão Pública. Niteroi-RJ: ed. Impetus, 2007. p. 17.
} 
3.4.2.1.3 - Informações prestadas diretamente.

Assim também, a fiscalização e o controle direto do Congresso quanto aos atos do Poder Executivo (art. 49, X) acontece com a busca direta de informações por meio de convocações pessoais das autoridades ou do encaminhamento a elas de pedidos de informações por escrito (o que é feito pelas Mesas Diretoras das respectivas Casas Legislativas) $^{128}$.

\subsubsection{4 - Julgamento de Contas do Chefe do Poder Executivo e do Governo.}

Quanto à competência prevista no art. 49, inciso IX da Constituição e que atribui ao Congresso Nacional a exclusividade para julgar as contas prestadas pelo Presidente da República, por força da Lei de Responsabilidade Fiscal (Lei Complementar n 101/2000) tais contas são denominadas “Contas do Governo da República” e compõem as informações que servem de base para a avaliação da gestão dos principais agentes políticos do Estado (respectivos Chefes de Poderes e Instituições).

Evidenciam elas o desempenho da arrecadação em relação à previsão, destacando as providências adotadas no âmbito da fiscalização das receitas e combate à sonegação, as ações de recuperação de créditos nas instâncias administrativa e judicial, bem como as demais medidas para incremento das receitas tributárias e contribuições. São prestadas anualmente tendo rito próprio de avaliação e julgamento (com caráter diferente das contas de gestão dos administradores). As contas da Presidência da República, em particular, recebem exame em bases macroeconômicas e sociais, além daquelas referentes aos quesitos fiscais, orçamentários, financeiros e patrimoniais ${ }^{129}$.

As Contas do Governo, cada uma delas, recebe parecer prévio do Tribunal de Contas da União antes de serem julgadas pelo Congresso Nacional, exceto a do próprio TCU, visto que compõem aquela do Governo (sendo o TCU considerado Tribunal Superior). São encaminhadas à uma Comissão (prevista no art. 166, inciso I, $\S 1^{\circ}$ da CF com denominação atual de Comissão Mista de Planos, Orçamentos Públicos e Fiscalização

\footnotetext{
${ }^{128}$ Art. 50, 'caput' e $\$ 2^{\circ}$ da CF.

129 CHAVES, Francisco Eduardo Carrilho. Controle Externo da Gestão Pública. Niteroi-RJ: ed. Impetus, 2007. p. 19
} 
do Congresso Nacional) e antes de serem juntadas às congêneres para julgamento pelo Congresso Nacional recebem um parecer emitido por esta comissão.

\subsubsection{5 - Disponibilização de Contas.}

Obedecendo à transparência, a Lei de Responsabilidade Fiscal determina, que as contas do Chefe do Executivo, incluídas as suas próprias, as dos Presidentes de órgãos dos Poderes Legislativo e Judiciário, do Tribunal de Contas e do Chefe do Ministério Público fiquem disponíveis durante todo o exercício, no respectivo Poder Legislativo e no órgão técnico responsável pela sua elaboração, para consulta e apreciação pelos cidadãos e instituições que compõem a sociedade.

O STF encontra-se julgando ADI ( ${ }^{\circ}$ 2.238/DF) na qual se argui a inconstitucionalidade dos artigos 56 e 57 da Lei de Responsabilidade Fiscal. Argumenta-se que apenas a emissão de parecer prévio das contas do Presidente da República seria constitucional e os pareceres quanto às contas dos demais Poderes e órgãos seriam inconstitucionais diante da remessa ao TCU pelo art. 71, II da $\mathrm{CF}^{130}$ do julgamento das contas dos Poderes Legislativo, Judiciário e Ministério Público e do próprio Tribunal de Contas. A ação encontra-se sem julgamento definitivo, porém constam decisões parciais e referência ao parecer da Procuradoria da República ${ }^{131}$.

\footnotetext{
${ }^{130}$ Art. 71. O controle externo, a cargo do Congresso Nacional, será exercido com o auxílio do Tribunal de Contas da União, ao qual compete: (...) II - julgar as contas dos administradores e demais responsáveis por dinheiros, bens e valores públicos da administração direta e indireta, incluídas as fundações e sociedades instituídas e mantidas pelo Poder Público federal, e as contas daqueles que derem causa a perda, extravio ou outra irregularidade de que resulte prejuízo ao erário público.

${ }^{131}$ Decisão: O Tribunal, por unanimidade, indeferiu a medida cautelar relativamente ao artigo 56, caput, e, por maioria, deferiu a cautelar quanto ao artigo 57, ambos da Lei Complementar $\mathrm{n}^{\circ} 101$, de 04 de maio de 2000, vencido o Senhor Ministro Ilmar Galvão (Relator), que a indeferia. Votou a Presidente, Ministra Ellen Gracie. Impedido o Senhor Ministro Gilmar Mendes. Lavrará o acórdão o sucessor do Ministro Ilmar Galvão, o Senhor Ministro Carlos Britto, que não participou da votação. Ausentes, justificadamente, os Senhores Ministros Celso de Mello e Eros Grau. Plenário, 08.08.2007. Decisão: Fica retificada a decisão proclamada na assentada anterior para constar que, quanto ao artigo 56, caput, da Lei Complementar $\mathrm{n}^{\circ}$ 101/2000, o Tribunal, à unanimidade, deferiu a cautelar, nos termos do voto do Relator. Ausente, nesta assentada, o Senhor Ministro Eros Grau. Presidência da Senhora Ministra Ellen Gracie. Em 17.04. 2012 foi juntada a petição $\mathrm{n}^{\circ}$ 18567/2012.18567/2012, da PGR, com parecer pelo conhecimento parcial da ação e, na parte conhecida, pela procedência parcial do pedido. Plenário, 09.08.2007.

http://www.stf.jus.br/portal/processo/verProcessoAndamento.asp?incidente=1829732 - Acesso em 12.03 .12
} 


\subsubsection{6 - Comissões Parlamentares.}

Já as Comissões Parlamentares de Inquérito podem somente exercer o controle da Administração em caráter eventual, isto é, se surgir notícia de indício de irregularidade. São criadas por requerimento de um terço dos membros das respectivas casas legislativas, podendo ser da Câmara dos Deputados, do Senado ou do Congresso Nacional (sendo então denominada Comissão Mista - CPMI e composta de deputados e senadores, obrigatoriamente). Podem quebrar sigilos fiscais, bancário, telefônico e de correspondência (embora não possam determinar a interceptação de comunicação telefônica ou correspondência em curso), além de requisitar informações referentes a sigilos já quebrados pela Justiça, realizar diligências e convocar pessoas para depor. Podem requisitar acesso a informações de interceptações telefônicas obtidas por meio judicial para instrução criminal devendo, entretanto, manter o sigilo em relação a tais informações.

Incumbe também à Comissão Mista permanente de Deputados e Senadores (art. 166, $\S 1^{\circ} \mathrm{CF}$ ) solicitar esclarecimentos da autoridade governamental responsável se surgirem indícios de despesas não autorizadas mesmo sob a forma de investimentos não programados ou de subsídios não aprovados, ou ainda qualquer outra despesa não autorizada. O responsável terá cinco dias corridos para se explicar. Se não forem prestados ou considerados insuficientes, o TCU será provocado para em trinta dias corridos emita um parecer conclusivo sobre a referida despesa e se a conclusão for pela irregularidade da despesa com a comissão concluindo que o gasto poderá causar dano irreparável ou grave lesão à economia pública, deverá a comissão propor ao Congresso Nacional sua sustação.

\subsubsection{7 - Sustação de execução contratual e relação com o Tribunal de Contas.}

A sustação de execução de contratos, por sua feita, acontece quando o Tribunal de Contas considera-os irregular. O TCU assinala prazo de até quinze dias, após detectada a irregularidade, para que o responsável adote providências para regularizar a avença e caso assim não aconteça o fato será comunicado ao Congresso ficando o Tribunal no aguardo da sustação ou não do contrato. Se esta acontecer não anula ou revoga o documento, que, entretanto deixa de produzir efeitos desde o ato da sustação. Se em 
noventa dias o Congresso Nacional ou o Poder Executivo não efetivar medidas para sanar irregularidades detectadas em contratos, o Tribunal de Contas decidirá a questão ${ }^{132}$.

No Estado de São Paulo, a Constituição Estadual apresenta determinações simétricas àquelas federais, inclusive no tocante às possíveis denúncias por parte de qualquer cidadão, partido político, associação ou entidade sindical visando apuração de crime de responsabilidade do Governador do Estado pela Assembleia Legislativa. Para os casos de crimes comuns, o Governador (ou o vice-governador e os secretários de estado, em crimes conexos) será julgado pelo Superior Tribunal de Justiça, entretanto, para os de responsabilidade será criado um "Tribunal Especial” composto por sete deputados, sete desembargadores sorteados pelo presidente do Tribunal de Justiça (e que será seu presidente) incumbindo ao Procurador-Geral de Justiça promover a respectiva ação (art. 116, I da Lei Estadual Complementar no 734/93).

Nota-se, assim, que o controle parlamentar acontece de forma direta (e também indireta) sendo por vezes preventivo e em outras repressivo e lembra Emile Blamont que "o efeito politico das medidas de controle parlamentar obscurece a sua eficácia na manutenção do equilíbrio da administração" ${ }^{\text {133 }}$ para referir a importância efetiva deste tipo de controle.

\subsubsection{2 - Tribunal de Contas.}

Neste contexto do controle externo, é de se referir a atuação dos Tribunais de Contas. Instituições tradicionais, que remontam ao período da Idade Média, merecem Capítulo próprio no presente trabalho, entretanto, cabe referência neste tópico, diante da adequação de suas competências no controle externo.

\footnotetext{
${ }^{132}$ Entretanto, encontra-se em decisão do STF: "O art. 71 da Constituição não insere na competência do TCU a aptidão para examinar, previamente, a validade de contratos administrativos celebrados pelo Poder Público. Atividade que se insere no acervo de competência da função executiva. É inconstitucional norma local que estabeleça a competência do tribunal de contas para realizar exame prévio de validade de contratos firmados com o Poder Público." (ADI 916, Rel. Min. Joaquim Barbosa, julgamento em 2-2-2009, Plenário, DJE de 6-3-2009.).

${ }^{133}$ BLAMONT, Émile. Lês conditions Du controle parlamentaire. Revue de Droit Public et de La Science Politique, abr-jun 1950, p.387, apud TÁCITO, Caio, Controle Judicial da Administração Pública. Revista de Direito Público, no 91, 1989.
} 
Órgão auxiliar, porém distinto, do Poder Legislativo, pode se dizer que é órgão administrativo, parajudicial, funcionalmente autônomo, cuja função consiste em exercer o controle externo, fático e jurídico sobre a execução financeiro-orçamentária, em face dos três Poderes do Estado, com decisões sem a definitividade jurisdicional ${ }^{134}$, acrescendo-se ainda o controle das contas do Ministério Público.

Apesar das equiparações funcionais e estruturais com o Poder Judiciário, não é órgão jurisdicional propriamente dito, visto que suas decisões não fazem coisa julgada no sentido técnico-processual do termo, embora algumas delas signifiquem exceção à regra, diante de seu caráter coercitivo ${ }^{135}$. Recorde-se a existência de normas que autorizam sanções e sustações (como a glosa de despesa diante de impugnação de valores apurados, com restituição de valores pelo responsável, prevista na Lei Orgânica do Tribunal de Contas da União). Entretanto suas decisões podem ser revistas pelo Poder Judiciário.

Conforme o art.70 da Constituição Federal, o Congresso Nacional é o titular do controle externo contábil, financeiro, orçamentário, patrimonial e operacional do Estado e o Tribunal de Contas exerce importante papel neste controle, na medida em que detém os instrumentos técnicos e operacionais para realizá-lo, ainda que se admita que o controle político seja da Casa Legislativa e o jurisdicional do Poder Judiciário.

As competências dos Tribunais de Contas encontram-se especificamente analisadas no Capítulo 4 deste trabalho.

\subsubsection{3 - Lei de Diretrizes Orçamentárias (17 de agosto de 2012).}

Recentemente foi aprovada a Lei no 12.708 de 17 de agosto de 2012 (Lei de Diretrizes Orçamentárias) que apresenta comandos sobre a fiscalização pelo Poder Legislativo e sobre as obras e os serviços com indícios de irregularidades graves.

\footnotetext{
${ }^{134}$ GUALAZZI, Eduardo Botelho Lobo. Regime jurídico dos Tribunais de Contas. São Paulo: RT, 1992, p.59.

${ }_{135}$ Como afirma Edmir Netto de Araújo, in ARAÚJO, Edmir Netto de, Curso de Direito Administrativo. São Paulo, Saraiva, 2006 p. 1206.
} 
Faz-se compatível diante da identidade com o escopo do presente trabalho indicar, em breves tópicos, o que está previsto.

Segundo o art. 93 a execução física, orçamentária e financeira dos contratos, convênios, etapas, parcelas ou subtrechos relativos a subtítulos nos quais forem identificados indícios de irregularidades graves constantes do anexo a que se refere o $\$ 2^{\circ}$ do art. $9^{\text {o136 }}$ ficará condicionada à prévia deliberação da Comissão Mista a que se refere o $\S 1^{\circ}$ do art. 166 da Constituição ${ }^{137}$, observado o disposto nos parágrafos $3^{\circ}$ e $4^{\circ}$ do art. $97^{138}$ da LDO.

Para os efeitos da LDO, entende-se por execução física, a realização da obra, fornecimento do bem ou prestação do serviço; execução orçamentária, o empenho e a liquidação da despesa, inclusive sua inscrição em restos a pagar; execução financeira, o pagamento da despesa, inclusive dos restos a pagar; indícios de irregularidades graves com recomendação de paralisação - IGP, os atos e fatos materialmente relevantes em relação ao valor total contratado que apresentem potencialidade de ocasionar prejuízos ao erário ou a terceiros e que possam ensejar nulidade de procedimento licitatório ou de contrato ou

\footnotetext{
${ }^{136} \S 2^{\circ}$ O Projeto de Lei Orçamentária de 2013 e a respectiva Lei conterão anexo específico com a relação dos subtítulos relativos a obras e serviços com indícios de irregularidades graves, cujas execuções observarão o disposto no Capítulo IX.

${ }^{137}$ Art. 166. Os projetos de lei relativos ao plano plurianual, às diretrizes orçamentárias, ao orçamento anual e aos créditos adicionais serão apreciados pelas duas Casas do Congresso Nacional, na forma do regimento comum. $\S 1^{\circ}$ - Caberá a uma Comissão mista permanente de Senadores e Deputados: I - examinar e emitir parecer sobre os projetos referidos neste artigo e sobre as contas apresentadas anualmente pelo Presidente da República; II - examinar e emitir parecer sobre os planos e programas nacionais, regionais e setoriais previstos nesta Constituição e exercer o acompanhamento e a fiscalização orçamentária, sem prejuízo da atuação das demais comissões do Congresso Nacional e de suas Casas, criadas de acordo com o art. 58.

${ }^{138}$ Art. 97. A Comissão Mista a que se refere o $\S 1^{\circ}$ do art. 166 da Constituição poderá realizar audiências públicas com vistas a subsidiar as deliberações acerca do bloqueio ou desbloqueio de contratos, convênios, etapas, parcelas ou subtrechos relativos a subtítulos nos quais forem identificados indícios de irregularidades graves. $\$ 1^{\circ}$ Serão convidados para as audiências os representantes dos órgãos e das entidades envolvidos, que poderão expor as medidas saneadoras já tomadas e as razões pelas quais as obras sob sua responsabilidade não devam ser paralisadas, inclusive aquelas a que se refere o art. 94, acompanhadas da justificação por escrito do titular do órgão ou entidade responsável pelas respectivas contratações. $2^{\circ}$ A deliberação da Comissão Mista a que se refere o $\S 1^{\circ}$ do art. 166 da Constituição que resulte na continuidade da execução de contratos, convênios, etapas, parcelas ou subtrechos relativos a subtítulos nos quais forem identificados indícios de irregularidades graves com recomendação de paralisação ainda não sanados dependerá da avaliação das informações recebidas na forma do $\S 2^{\circ}$ do art. 94 e de prévia realização da audiência pública prevista no caput, quando deverão ser avaliados os prejuízos potenciais da paralisação para a administração pública e para a sociedade. $\$ 3^{\circ} \mathrm{A}$ decisão pela paralisação ou pela continuidade de obras ou serviços com indícios de irregularidades graves, nos termos do $\$ 2^{\circ}$, dar-se-á sem prejuízo da continuidade das ações de fiscalização e da apuração de responsabilidades dos gestores que lhes deram causa. \} ^ { \circ } \text { Após a publicação da } Lei Orçamentária de 2013, o bloqueio e o desbloqueio da execução física, orçamentária e financeira nos termos deste Capítulo dar-se-ão mediante decreto legislativo baseado em deliberação da Comissão Mista a que se refere o $\S 1^{\circ}$ do art. 166 da Constituição, à qual cabe divulgar, pela internet, a relação atualizada dos subtítulos de que trata o caput.
} 
configurem graves desvios relativamente aos princípios constitucionais a que está submetida a administração pública federal.

Também se considera indício de irregularidade grave com recomendação de retenção parcial de valores - IGR, aquele que, embora atenda à conceituação mencionada acima, permite a continuidade da obra desde que haja autorização do contratado para retenção de valores a serem pagos, ou a apresentação de garantias suficientes para prevenir o possível dano ao erário, até a decisão de mérito sobre o indício relatado e indício de irregularidade grave que não prejudique a continuidade - IGC, aquele que, embora gere citação ou audiência do responsável, não atende àquela conceituação (incisos IV ou V do $§$ $\left.1^{\mathrm{o}}\right)$.

Os ordenadores de despesa e os órgãos setoriais de orçamento deverão providenciar o bloqueio, nos sistemas próprios, da execução física, orçamentária e financeira dos contratos, convênios, etapas, parcelas ou subtrechos constantes do anexo a que se refere o $\S 2^{\circ}$ do art. $9^{\circ}$, permanecendo nessa situação até a deliberação em contrário da Comissão Mista a que se refere o $\S 1^{\circ}$ do art. 166 da Constituição, sendo que não estão sujeitos ao bloqueio da execução (a que se refere o $\S 2^{\circ}$ ), os casos para os quais tenham sido apresentadas garantias suficientes à cobertura integral dos prejuízos potenciais ao erário, nos termos da legislação pertinente.

Os pareceres da Comissão Mista acerca de obras e serviços com indícios de irregularidades graves deverão ser fundamentados, explicitando as razões da deliberação.

Já a inclusão, no Projeto de Lei Orçamentária de 2013 e na respectiva Lei, assim como em créditos adicionais, de subtítulos relativos a obras e serviços com indícios de irregularidades graves obedecerá, sempre que possível, à mesma classificação orçamentária constante das leis orçamentárias anteriores, ajustada à lei do plano plurianual, conforme o caso.

A classificação, pelo Tribunal de Contas da União, das constatações de fiscalização nas modalidades previstas nos incisos IV e V do $\$ 1^{\circ}$, dar-se-á por decisão monocrática ou colegiada, que deve ser proferida no prazo máximo de quarenta dias corridos a contar da conclusão da auditoria pela unidade técnica, dentro do qual deverá ser 
assegurada a oportunidade de manifestação preliminar, em quinze dias corridos, aos órgãos e às entidades aos quais foram atribuídas as supostas irregularidades.

O enquadramento na classificação a que se refere o $\S 9^{\circ}$ poderá ser revisto a qualquer tempo mediante ulterior decisão monocrática ou colegiada do Tribunal de Contas da União, em face de novos elementos de fato e de direito apresentados pelos interessados.

Conforme o art. 94, o Congresso Nacional levará em consideração, na sua deliberação pelo bloqueio ou desbloqueio da execução física, orçamentária e financeira de contratos, convênios, etapas, parcelas ou subtrechos relativos aos subtítulos de obras e serviços com indícios de irregularidades graves, a classificação da gravidade do indício, nos termos estabelecidos nos incisos IV, V e VI do $\S 1^{\circ}$ do art. 93, e as razões apresentadas pelos órgãos e entidades responsáveis pela execução.

Em especial deverá observar os impactos econômicos e financeiros decorrentes do atraso na fruição dos benefícios do empreendimento; os riscos sociais, ambientais e à segurança da população local decorrentes do atraso na fruição dos benefícios do empreendimento; a motivação social e ambiental do empreendimento; o custo da deterioração ou perda das parcelas executadas; as despesas necessárias à preservação das instalações e dos serviços já executados; as despesas inerentes à desmobilização e ao posterior retorno às atividades; as medidas efetivamente adotadas pelo titular do órgão ou entidade para o saneamento dos indícios de irregularidades apontados; e o custo total e o estágio de execução física e financeira de contratos, convênios, obras ou parcelas envolvidas.

A apresentação das razões a que se refere o art. 94 é de responsabilidade do titular do órgão ou da entidade federal, executor ou concedente, responsável pela obra ou serviço em que se tenha verificado indício de irregularidade, no âmbito do Poder Executivo ou do titular do órgão dos Poderes Legislativo e Judiciário e do Ministério Público da União, para as obras e serviços executados no respectivo âmbito.

Tais razões serão encaminhadas ao Congresso Nacional, por escrito, pelos responsáveis mencionados no $\S 1^{\circ}$ para as obras e os serviços constantes da relação de que trata o inciso I do caput do art. 95, no prazo a que se refere o art. 10; para as obras e os 
serviços constantes da relação de que trata o inciso II do caput do art. 95, em até quinze dias da publicação do acórdão do Tribunal de Contas da União que aprove a forma final da mencionada relação; e no caso das informações encaminhadas na forma do art. 98, em até quinze dias a contar do recebimento da decisão monocrática ou da publicação do acórdão a que se refere o $\$ 9^{\circ}$ do art. 93.

É facultado aos responsáveis mencionados no $\S 1^{\circ}$, bem como ao titular do órgão ou da entidade responsável pelas respectivas contratações, apresentar as razões de que trata este artigo também ao Tribunal de Contas da União durante as ações de fiscalização do empreendimento, sendo que a omissão na prestação das informações na forma e nos prazos do $\S 2^{\circ}$ não impedirá as decisões da Comissão Mista (referida no $\S 1^{\circ}$ do art. 166 da CF) e do Congresso Nacional, nem retardará a aplicação de qualquer de seus prazos de tramitação e deliberação.

Dispõe o art. 95 que para fins do disposto no inciso $\mathrm{V}$ do $\S 1^{\circ}$ do art. 59 da Lei de Responsabilidade Fiscal e no art. $9^{\circ}, \S 2^{\circ}$ da LDO, o Tribunal de Contas da União encaminhará: I - à Secretaria de Orçamento Federal do Ministério do Planejamento, Orçamento e Gestão e aos órgãos setoriais do Sistema de Planejamento e de Orçamento Federal, até $1^{\circ}$ de agosto de 2012, a relação das obras e dos serviços com indícios de irregularidades graves, com o correspondente banco de dados, especificando as classificações institucional, funcional e programática vigentes, com os respectivos números dos contratos e convênios, na forma do Anexo VI da Lei Orçamentária de 2012, acrescida do custo global estimado de cada obra ou serviço listado e do respectivo estágio da execução física, com a data a que se referem essas informações; e II - à Comissão Mista, até setenta dias após o encaminhamento do projeto de lei orçamentária, a relação atualizada de contratos, convênios, etapas, parcelas ou subtrechos relativos aos subtítulos nos quais forem identificados indícios de irregularidades graves, classificados na forma disposta nos incisos IV, V e VI do $\S 1^{\circ}$ do art. 93, bem como a relação daqueles que, embora tenham tido recomendação de paralisação da equipe de auditoria, não foram objeto de decisão monocrática ou colegiada no prazo previsto no $\S 9^{\circ}$ do art. 93, acompanhadas de cópias em meio eletrônico das decisões monocráticas e colegiadas, dos Relatórios e Votos que as fundamentarem e dos relatórios de auditoria das obras e dos serviços fiscalizados. 
É obrigatória a especificação dos contratos, convênios ou editais relativos a etapas, parcelas ou subtrechos nos quais foram identificados indícios de irregularidades graves, bem como da decisão monocrática ou acórdão ao qual se refere o $\$ 9^{\circ}$ do art. 93 , sendo que o Tribunal de Contas da União manterá as informações sobre obras e serviços com indícios de irregularidades graves de que trata este artigo atualizadas na sua página na internet.

E conforme o art. 96 a seleção das obras e dos serviços a serem fiscalizados pelo Tribunal de Contas da União deve considerar, entre outros fatores: I - os valores autorizados e empenhados no exercício anterior e no exercício atual; II - os projetos de grande vulto; III - a regionalização do gasto; IV - o histórico de irregularidades pendentes obtidos a partir de fiscalizações anteriores e a reincidência de irregularidades cometidas; $\mathrm{V}$ - as obras contidas no Anexo; VI - Subtítulos relativos a Obras e Serviços com Indícios de Irregularidades Graves da lei orçamentária em vigor que não foram objeto de deliberação posterior do Tribunal de Contas da União pela regularidade.

O Tribunal de Contas da União deverá, adicionalmente, enviar informações sobre outras obras ou serviços nos quais tenham sido constatados indícios de irregularidades graves em outros procedimentos fiscalizatórios realizados nos últimos doze meses, contados da publicação da LDO, com o grau de detalhamento definido no $\S 2^{\circ}$ do art. 96, observados ainda os incisos IV, V e VI do $\S 1^{\circ}$ e o $\S 9^{\circ}$ do art. 93.

Daquela seleção referida constarão, para cada obra fiscalizada, sem prejuízo de outros dados considerados relevantes pelo Tribunal de Contas da União: I - as classificações institucional, funcional e programática, atualizadas de acordo com a Lei Orçamentária de 2012; II - a sua localização e especificação, com as etapas, as parcelas ou os subtrechos e seus respectivos contratos e convênios, conforme o caso; III - o CNPJ e a razão social da empresa responsável pela execução da obra ou do serviço nos quais foram identificados indícios de irregularidades graves, nos termos dos incisos IV, V e VI do $§ 10$ do art. 93, bem como o nome do órgão ou da entidade responsável pela contratação; IV - a natureza e a classificação dos indícios de irregularidades de acordo com sua gravidade, bem como o pronunciamento acerca da estimativa do valor potencial do prejuízo ao erário e de elementos que recomendem a paralisação preventiva da obra; V - as providências já adotadas pelo Tribunal de Contas da União quanto às irregularidades; VI - o percentual de 
execução físico-financeira; VII - a estimativa do valor necessário para conclusão; VIII - as manifestações prévias do órgão ou da entidade fiscalizada aos quais tenham sido atribuídas as supostas irregularidades, bem como as correspondentes decisões, monocráticas ou colegiadas, com os relatórios e votos que as fundamentarem, quando houver; IX - o conteúdo das eventuais alegações de defesa apresentadas e sua apreciação; e X - as eventuais garantias de que trata o $\S 3^{\circ}$ do art. 93, identificando o tipo e o valor.

As unidades orçamentárias responsáveis por obras e serviços que constem, em dois ou mais exercícios, do Anexo a que se refere o $\$ 2^{\circ}$ do art. $9^{\circ}$ devem informar à Comissão Mista a que se refere o $\$ 1^{\circ}$ do art. 166 da Constituição, até trinta dias após o encaminhamento da Proposta Orçamentária de 2013, as providências tomadas para sanar as irregularidades apontadas em decisão do Tribunal de Contas da União em face da qual não caiba mais recurso perante aquela Corte.

Para efeito do que dispõe o $\S^{\circ}$ do art. 97, o Tribunal de Contas da União encaminhará informações nas quais constará pronunciamento conclusivo quanto a irregularidades graves que não se confirmaram ou ao seu saneamento e sempre que a informação encaminhada implicar reforma de deliberação anterior, deverão ser evidenciadas a decisão reformada e a correspondente decisão reformadora.

O art. 97 indica que a Comissão Mista poderá realizar audiências públicas com vistas a subsidiar as deliberações acerca do bloqueio ou desbloqueio de contratos, convênios, etapas, parcelas ou subtrechos relativos a subtítulos nos quais forem identificados indícios de irregularidades graves, quando então serão convidados para as audiências os representantes dos órgãos e das entidades envolvidos, que poderão expor as medidas saneadoras já tomadas e as razões pelas quais as obras sob sua responsabilidade não devam ser paralisadas, inclusive aquelas a que se refere o art. 94, acompanhadas da justificação por escrito do titular do órgão ou entidade responsável pelas respectivas contratações.

A deliberação da Comissão Mista que resulte na continuidade da execução de contratos, convênios, etapas, parcelas ou subtrechos relativos a subtítulos nos quais forem identificados indícios de irregularidades graves com recomendação de paralisação ainda não sanados dependerá da avaliação das informações recebidas na forma do $\S 2^{\circ}$ do 
art. 94 e de prévia realização da audiência pública prevista no caput, quando deverão ser avaliados os prejuízos potenciais da paralisação para a administração pública e para a sociedade.

A decisão pela paralisação ou pela continuidade de obras ou serviços com indícios de irregularidades graves dar-se-á sem prejuízo da continuidade das ações de fiscalização e da apuração de responsabilidades dos gestores que lhes deram causa.

Após a publicação da Lei Orçamentária de 2013, o bloqueio e o desbloqueio da execução física, orçamentária e financeira nos termos aqui referidos dar-se-ão mediante decreto legislativo baseado em deliberação da Comissão Mista a que se refere o $\S 1^{\circ}$ do art. 166 da Constituição, à qual cabe divulgar, pela internet, a relação atualizada dos subtítulos de que trata o 'caput'.

O art. 98 prevê que durante o exercício de 2013, o Tribunal de Contas da União remeterá ao Congresso Nacional e ao órgão ou à entidade fiscalizada, no prazo de até quinze dias da decisão ou Acórdão aos quais se refere o art. 93, nos parágrafos $9^{\circ}$ e $10^{\circ}$, informações relativas a novos indícios de irregularidades graves identificados em contratos, convênios, etapas, parcelas ou subtrechos relativos a subtítulos constantes da Lei Orçamentária de 2013, inclusive com as informações relativas às execuções física, orçamentária e financeira, acompanhadas das manifestações dos órgãos e das entidades responsáveis pelas obras que permitam a análise da conveniência e oportunidade de bloqueio das respectivas execuções física, orçamentária e financeira.

O Tribunal de Contas da União disponibilizará à Comissão Mista a que se refere o $\S 1^{\circ}$ do art. 166 da Constituição acesso ao seu sistema eletrônico de fiscalização de obras e serviços, sendo que os processos relativos a obras ou serviços que possam ser objeto de bloqueio nos termos dos arts. 93 e 94 serão instruídos e apreciados prioritariamente pelo Tribunal de Contas da União, devendo a decisão indicar, de forma expressa, se as irregularidades inicialmente apontadas foram confirmadas e se o empreendimento questionado poderá ter continuidade sem risco de prejuízos significativos ao erário, no prazo de até quatro meses, contado da comunicação prevista no caput. 
Caso o empreendimento não possa ter continuidade, a decisão mencionada deverá relacionar todas as medidas a serem adotadas pelos responsáveis, com vistas ao saneamento das irregularidades graves e após a manifestação do órgão ou entidade responsável quanto à adoção das medidas corretivas, o Tribunal de Contas da União deverá se pronunciar sobre o efetivo cumprimento dos termos da decisão de que trata o $\S 2^{\circ}$, no prazo de até três meses, contado da data de entrega da citada manifestação.

Na impossibilidade de cumprimento dos prazos estipulados nos parágrafos $2^{\circ}$ e $4^{\circ}$, o Tribunal de Contas da União deverá informar e justificar ao Congresso Nacional as motivações do atraso.

O Tribunal de Contas da União encaminhará, até 15 de maio de 2013, à Comissão Mista a que se refere o $\S 1^{\circ}$ do art. 166 da Constituição relatório contendo as medidas saneadoras adotadas e as pendências relativas a obras e serviços com indícios de irregularidades graves, que poderá realizar audiências públicas, na forma do art. 97, para subsidiar a apreciação do relatório.

E segundo o art. 99 o Tribunal de Contas da União enviará à Comissão Mista, até trinta dias após o encaminhamento da Proposta Orçamentária de 2013, quadroresumo relativo à qualidade da implementação e ao alcance de metas e objetivos dos programas e ações governamentais objeto de auditorias operacionais realizadas, para subsidiar a discussão do Projeto de Lei Orçamentária de 2013.

Consta que a eficácia do Anexo VII da LDO está condicionada, para todos os efeitos, à efetiva programação das ações no projeto e na lei orçamentária e com vistas à apreciação da Proposta Orçamentária de 2013, ao acompanhamento e à fiscalização orçamentária a que se referem o art. 70 e o inciso II do parágrafo $1^{\circ}$ do art. 166 da Constituição, será assegurado aos membros e órgãos competentes dos Poderes da União, inclusive ao Tribunal de Contas da União, ao Ministério Público Federal e à ControladoriaGeral da União, o acesso irrestrito, para consulta, aos diversos sistemas ${ }^{139}$ ou informações, bem como o recebimento de seus dados, em meio digital:

${ }^{139}$ SIAFI; SIOP; Sistema de Análise Gerencial da Arrecadação - ANGELA, bem como as estatísticas de dados agregados relativos às informações constantes das declarações de imposto de renda das pessoas físicas e jurídicas, respeitado o sigilo fiscal do contribuinte; Sistema Integrado de Tratamento Estatístico de Séries 
Os cidadãos e as entidades sem fins lucrativos, credenciados segundo requisitos estabelecidos pelos órgãos gestores dos sistemas, poderão ser habilitados para consulta aos sistemas e cadastros mencionados. Assim também, em cumprimento ao 'caput' do art. 70 da Constituição, o acesso irrestrito referido no 'caput' será igualmente assegurado aos membros do Congresso Nacional, para consulta, partir de 30 de outubro de 2012, aos sistemas ou informações referidos nos incisos II e V do 'caput', nos maiores níveis de amplitude, abrangência e detalhamento existentes, e por iniciativa própria, a qualquer tempo, aos demais sistemas e cadastros.

As disposições da Lei de Diretrizes Orçamentárias e as previsões da Lei de Responsabilidade Fiscal (Lei Complementar 101 de 04 de maio de 2000) que apresenta tópico a respeito da preservação do Patrimônio Público (artigos 44 a 46) devem estar em consonância.

Consta da LRF que é vedada a aplicação da receita de capital derivada da alienação de bens e direitos que integram o patrimônio público para o financiamento de despesa corrente, salvo se destinada por lei aos regimes de previdência social, geral e próprio dos servidores públicos.

E ainda, conforme o art. $5^{\circ}, \S 5^{\circ}$ da $\mathrm{CF}$ (que diz que a lei orçamentária não consignará dotação para investimento com duração superior a um exercício financeiro que não esteja previsto no plano plurianual ou em lei que autorize a sua inclusão, conforme disposto no $\S 1^{\mathrm{o}}$ do art. 167 da Constituição ${ }^{140}$ ), a lei orçamentária e as de créditos adicionais só incluirão novos projetos após adequadamente atendidos os em andamento e contempladas as despesas de conservação do patrimônio público, incumbindo à lei de diretrizes orçamentárias dispor sobre seus termos.

Estratégicas - SINTESE; SIEST; SIASG; Sistema de Informações Gerenciais de Arrecadação - INFORMAR; Cadastro das entidades qualificadas como OSCIP, mantido pelo Ministério da Justiça; CNPJ; Sistema de Informação e Apoio à Tomada de Decisão - SINDEC, do Departamento Nacional de Infraestrutura de Transportes - DNIT; SICONV; Sistema de Monitoramento do Programa de Aceleração do Crescimento SISPAC; Sistema de Acompanhamento de Contratos - SIAC, do DNIT; CNEA, do Ministério do Meio Ambiente; Sistema de Informação sobre Orçamento Público em Saúde - SIOPS; Sistema de Informações sobre Orçamentos Públicos em Educação - SIOPE; e Sistema de Coleta de Dados Contábeis dos Entes da Federação - SISTN.

${ }^{140} \mathrm{CF}$ - art. $167, \S 1^{\circ}$ - Nenhum investimento cuja execução ultrapasse um exercício financeiro poderá ser iniciado sem prévia inclusão no plano plurianual, ou sem lei que autorize a inclusão, sob pena de crime de responsabilidade. 
O Poder Executivo de cada ente encaminhará ao Legislativo, até a data do envio do projeto de lei de diretrizes orçamentárias, relatório com as informações necessárias ao cumprimento do que consta como previsão para inclusão dos novos projetos, ao qual será dada ampla divulgação.

Também há comando indicativo de que é nulo de pleno direito o ato de desapropriação de imóvel urbano expedido sem o atendimento do disposto no $\S 3^{\circ}$ do art. 182 da Constituição (que diz que as desapropriações de imóveis urbanos serão feitas com prévia e justa indenização em dinheiro) ou prévio depósito judicial do valor da indenização $^{141}$.

\subsubsection{4 - O Controle Externo pelo Poder Judiciário.}

Embora não seja unânime na doutrina, também é possível se admitir a classificação que insere o controle externo pelo Poder Judiciário, ainda que interessante distinção diante do Controle do Parlamento se encontre na exigência da provocação por quem se sinta ofendido (partes). Estes podem ser desde o cidadão e/ou entidades que o representem, como sindicatos, ONGs ou associações de classe, tanto como o próprio Ministério Público (apontando para o controle social inserido no controle externo).

A prática de atos materiais ou a edição de ato administrativo pelo administrador público pode não estar consoante o modelo legal ou o interesse público, restando lesão a direitos ou interesses dos administrados, seja de modo individual, seja coletivo. Assim, cabível o recurso ao Poder Judiciário para restabelecimento da ordem jurídica violada. A Constituição Federal garante (Art. 50, inciso XXXV) que "a lei não excluirá da apreciação do Poder Judiciário lesão ou ameaça a direito", assentando-se neste postulado o fundamento do controle jurisdicional da atividade administrativa.

\footnotetext{
141 Cabe lembrar, no tema de aquisição de patrimônio público, que a Constituição Federal, no art.183, $\S 3^{\circ}$, ao tratar da Política Urbana afirma que os imóveis públicos não podem ser adquiridos por usucapião.
} 
Portanto, o controle jurisdicional da Administração é exercido pelo Poder Judiciário (sistema da jurisdição una, adotado no Brasil) seja sobre atos do Poder Executivo, Legislativo (incluindo atos do Tribunal de Contas), do próprio Judiciário (quando de suas atividades administrativas) e ainda do Ministério Público (também em suas atividades administrativas internas).

Em geral acontece posteriormente à edição ou prática do ato com objetivo de verificar a legalidade tanto no aspecto formal, quanto de competência, finalidade e forma, evitando o desvio de poder, tema que merece breve abordagem.

\subsubsection{1 - Desvio de Poder.}

Alguns sintomas denunciadores do desvio de poder podem ser encontrados em situações de contradição do ato com atos anteriores ou posteriores, motivação exagerada ou excessiva, insuficiente ou contraditória, ilogicidade manifesta, injustiça e disparidade de tratamento, alteração dos fatos, derrogação de norma interna, precipitação na edição do ato e o feixe convergente de tais indícios.

Muitas vezes, as locuções desvio de poder, abuso de poder, excesso de poder e desvio de finalidade são compreendidas como sinônimos. Contudo, o uso indiscriminado de tais locuções não é da melhor técnica jurídica. Precisamente, aquilo que se entende por desvio de poder assume feições muito particulares, razão pela qual é imprescindível estabelecer, de início, as distinções necessárias.

Conforme ensinam Edmir Netto de Araújo ${ }^{142}$ e também Hely Lopes Meirelles ${ }^{143}$, a expressão abuso de poder é genérica, englobando tanto o excesso de poder, ou abuso de poder em sentido estrito, como o desvio de poder.

\footnotetext{
${ }^{142}$ ARAUJO, Edmir Netto de. Curso de Direito Administrativo. 5a ed. São Paulo: Saraiva, 2010; p. 1092 a 1095

${ }^{143}$ MEIRELLES, Hely Lopes. Direito Administrativo Brasileiro. 34a ed. São Paulo: Malheiros, 2008; p. 114 e 115 .
} 
O excesso de poder, ou abuso de poder stricto sensu, remetem à ideia de delimitação da competência. Nos casos de abuso de poder o agente agiu fora dos limites de competência fixados pela lei. A autoridade atua em flagrante ilegalidade: seja porque agiu sem competência para tanto, seja porque extrapolou, agiu com excesso, indo além daquilo que lhe permitia sua competência.

Por exemplo, um chefe de sessão que detenha autoridade para fiscalizar o material de consumo (mesas, cadeiras etc.), portanto, elementos integrantes do patrimônio público, e se depare com alguns em deterioração pode ter competência para notificar superior hierárquico para que este decida sobre providências de recolhimento do material, entretanto se determinar, do modo isolado, que sejam simplesmente enviados ao lixo ou doados, sem avaliação, poderá estar causando prejuízo patrimonial à administração pública (visto que poderiam ser reformados) além de extrapolar sua competência.

Diferentemente, o desvio de poder se caracteriza por não apresentar qualquer ilegalidade formal, sendo que a contrariedade ao Direito encontra-se no desvio de finalidade e no móvel do agente. No desvio de poder, há higidez formal do ato: o agente atua dentro de sua competência, em obediência aos preceitos formais, no entanto, pratica ato para atingir finalidade diversa da que a lei, implícita ou implicitamente, lhe determina. É esta a definição para desvio de finalidade contida na lei de ação popular, art. $2^{\circ}$, parágrafo único, alínea "e": "o desvio de finalidade se verifica quando o agente pratica o ato visando a fim diverso daquele previsto, explícita ou implicitamente, na regra de competência.”.

A problemática em torno do desvio de poder não se encontra concentrada na finalidade prescrita pela lei. De fato, a lei, qualquer que seja, sempre objetivará um dever genérico de persecução do interesse público, sendo esta a finalidade última de uma lei dirigida à administração pública.

Ocorre, não raras vezes, que é possível haver desvio de finalidade com o atendimento, ao menos, aparente do interesse público. Assim, a ação de um Prefeito municipal que desaproprie propriedade de um inimigo político sob o argumento de que irá construir um hospital no local indica que, o vício se encontra na vontade do agente e não tanto na finalidade. Visando prejudicar o inimigo, poderá estar afetando o patrimônio 
público quando de eventual ação para desconstituição do ato, na medida em que haverá dispêndio de tempo e recursos tanto de pessoal como financeiros na transação. Poderá, também, eventualmente, ser condenado a ressarcir o erário, além do fato que se tivesse escolhido local adequado sem aquela intenção indevida, o hospital poderia ter sido construído, efetivamente.

\subsubsection{2 - Mitigações ao controle jurisdicional.}

Não se pode falar em exceção à regra do controle jurisdicional, porém é possível que se admita a existência de mitigações à amplitude dos meios de controle. Neste sentido observa-se que o art. 647 do Código de Processo Penal diz que não cabe habeas corpus em caso de transgressões disciplinares, devendo o direito ser buscado por vias ordinárias, também se pesquisando hipótese mitigadora da atuação judiciária quando de mandado de segurança impetrado diante de punição administrativa, quando o juiz não poderá ingressar no mérito da punição (valoração interna do ato), verificando se ela foi ou não justa, limitando-se a conferir a competência da autoridade, nulidade da forma ou desvio de finalidade.

Atos políticos podem ser objeto do controle, porém não quanto ao aspecto propriamente político, mas sim na defesa de eventuais direitos violados ou se arbitrariedade for verificada.

Importante discussão se estabelece quanto à questão da discricionariedade, visto ser a mais complexa limitação à extensão do controle jurisdicional ${ }^{144}$. Isto porque a doutrina e jurisprudência tradicionais sempre entenderam que o Poder Judiciário somente poderia se limitar à análise da legalidade dos atos administrativos, sendo vedado imiscuirse no mérito (o aspecto discricionário). Entretanto, diante da natural evolução e a nova forma de se ver a atuação do poder público, outro enfoque se avizinhou, adotando caráter ampliativo para a atuação do Poder Judiciário, embora ainda não totalmente solidificado, na medida em que não fixados adequados parâmetros objetivos para o correto entendimento do que seria a 'discricionariedade', restando aparência de subjetividade.

\footnotetext{
${ }^{144}$ Como afirma Edmir Netto de Araújo in ARAÚJO, Edmir Netto de. Curso de Direito Administrativo. São Paulo, Saraiva, 2006. p. 1209.
} 
Possível, porém, que se admita que o administrador público detenha espectro de escolha dentre aquelas adequadas aos limites fixados na lei, e não somente no aspecto da legalidade, mas também, e principalmente de economicidade e eficiência. Vale dizer, dentre várias escolhas e caminhos que pode adotar, deve necessariamente escolher aquele que melhor atende o interesse público (adotando-se objetivamente para o termo 'interesse público' critérios discutidos no presente trabalho, acerca de eficiência, economicidade etc.).

Neste sentido, se a escolha recair em outra em que o interesse público não tenha sido adequadamente atendido (mesmo que corretos os demais requisitos de forma e competência) poderá ser questionado pelos legitimados junto ao Poder Judiciário, evidenciando uma nova forma de controle.

O mesmo raciocínio se aplica se determinada escolha do administrador resultar em algum prejuízo patrimonial ao ente público, como se pode extrair do comando normativo da Lei no 8.429/92 referente ao 'prejuízo ao erário'.

A título de exemplo, a grosso modo é possível se supor uma licitação para construção de uma ponte em determinado município em que todos os requisitos de legalidade e economicidade estejam atendidos, com Edital admitido como formalmente correto em análise prévia do Tribunal de Contas e preço adequado ao de mercado, porém com a sociedade questionando se a escolha do local teria sido a melhor, apresentando representação ao Ministério Público. Este, em autos de inquérito civil poderia eventualmente concluir que, a despeito de formalidades absolutamente certas e preço adequado para aquela obra, se a ponte tivesse sido construída em outro local (devidamente apurado em perícia) o resultado mais favorável ao deslocamento da população e com preço menor, representando, então, aquela obra específica, prejuízo ao erário e à sociedade local (independentemente da apuração se houve favorecimento pessoal ao administrador para realizar a escolha tida como inadequada, o que é comum em exemplos como tais). Evidentemente não seria possível pedido em juízo para demolição da ponte (com perda ainda maior ao patrimônio público), mas cabível a análise de indenização em favor do erário por parte do administrador, se considerado ímprobo. 
O exemplo, é claro, permite, diante de outras variáveis, interpretações distintas, porém serve a ilustrar o enfoque de novos parâmetros para avaliar a conduta do administrador público.

É fato que existe espectro de natureza subjetiva no tema e tanto os legitimados para contestar a decisão como o próprio Poder Judiciário não podem se substituir ao administrador em sua função, buscando 'ditar' a política pública a ser implementada anulando atos administrativos praticados na busca da indicação de que outro ato deva substituí-lo, necessariamente ${ }^{145}$. Deve ser preservada a autonomia e a independência entre os Poderes. Assim, o caso concreto irá mostrar os limites do controle a ser exercido.

Helly Lopes Meirelles ${ }^{146}$ indica que “... a livre determinação do objeto do ato administrativo é o núcleo do poder discricionário, que se insere entre a verificação da existência dos motivos de fato e de direito, verificação esta passível de controle jurisdicional; e a avaliação desses motivos, que se situa fora do controle jurisdicional".

3.4.2.4.3 - Instrumentos judiciais de controle.

Os modos de efetuar o controle se encontram nos tipos de ações que podem ser movidas para adequação do ato a ser contrariado, sendo que os direitos comuns ou ordinários podem ser defendidos por ações ordinárias ou ações especiais (diante de procedimentos próprios que são previstos), sempre lembrando que é possível se extrair hipótese de impacto de natureza patrimonial frente à administração pública, o que justifica a análise. Vejamos:

\footnotetext{
${ }^{145}$ Diante de tal afirmação, recorde-se decisão que, guardadas as proporções devidas, mostra que o Poder Judiciário não pode substituir o Legislativo (ou o Executivo): em 1993, em análise de controle concentrado, o STF julgou a ADI 896/DF, cujo relator foi o Ministro Moreira Alves, na qual foi decidido, por maioria de votos, o seguinte: "Não só a Corte está restrita a examinar os dispositivos ou expressões cuja inconstitucionalidade for arguida, mas também não pode ela declarar inconstitucionalidade parcial que mude o sentido e o alcance da norma impugnada (quando isso ocorre, a declaração de inconstitucionalidade tem que alcançar a todo o dispositivo), porquanto, se assim não fosse, a Corte se transformaria em legislador positivo, uma vez que, com a supressão da expressão atacada, estaria modificando o sentido e o alcance da norma impugnada. E o controle de constitucionalidade dos atos normativos só the permite agir como legislador negativo." Como referido por SCAFF, Fernando Facury. Sentenças Aditivas, Direitos Sociais e Reserva do Possível. Revista Dialética de Direito Processual, no 51, p.90, 2007 - (grifo não original).

${ }^{146}$ MEIRELLES, Hely Lopes. Direito Administrativo Brasileiro. 34a ed. São Paulo: Malheiros, 2008; p. 111 e 196.
} 


\subsection{1 - Ação Direta de inconstitucionalidade e Representação Interventiva.}

Ação de inconstitucionalidade ou representação interventiva, que servem a questionar a lei em tese e que podem ser propostas ${ }^{147}$ pelo Presidente da República; pela Mesa do Senado Federal; pela Mesa da Câmara dos Deputados; pela Mesa de Assembleia Legislativa ou da Câmara Legislativa do Distrito Federal; pelo Governador de Estado ou do Distrito Federal; pelo Procurador-Geral da República; pelo Conselho Federal da Ordem dos Advogados do Brasil; por partido político com representação no Congresso Nacional; e por confederação sindical ou entidade de classe de âmbito nacional, sendo obrigatória a oitiva prévia do Procurador-Geral da República.

A ação direta de inconstitucionalidade visa que o Supremo Tribunal Federal anule atos legislativos (as leis formais e demais atos normativos) eivados de vício de natureza constitucional, tendo como efeito a retirada da norma do mundo jurídico. Existe ação em paralelo nos Estados da federação, sendo impetrada diante do respectivo Tribunal de Justiça frente a normas do Poder Legislativo local (estadual ou municipal) em colidência com a Constituição Estadual respectiva.

A representação interventiva significa a possibilidade da intervenção de um ente da federação em outro de hierarquia inferior (União nos Estados e Municípios e Estados nos Municípios) e acontece em caráter de exceção, visto que a regra é a não intervenção em respeito ao princípio federativo. Os fundamentos constitucionais tem escopo administrativo-financeiros, políticos e jurídicos ${ }^{148}$. Diante do caráter extremamente

\footnotetext{
147 Art. 103, I a IX da CF

${ }^{148}$ Artigos 34 e 35 apontam que a União somente poderá intervir nos Estados e no Distrito Federal, exceto para: I - manter a integridade nacional; II - repelir invasão estrangeira ou de uma unidade da Federação em outra; III - pôr termo a grave comprometimento da ordem pública; IV - garantir o livre exercício de qualquer dos Poderes nas unidades da Federação; V - reorganizar as finanças da unidade da Federação que: a) suspender o pagamento da dívida fundada por mais de dois anos consecutivos, salvo motivo de força maior; b) deixar de entregar aos Municípios receitas tributárias fixadas nesta Constituição, dentro dos prazos estabelecidos em lei; VI - prover a execução de lei federal, ordem ou decisão judicial; VII - assegurar a observância dos seguintes princípios constitucionais: a) forma republicana, sistema representativo e regime democrático; b) direitos da pessoa humana; c) autonomia municipal; d) prestação de contas da administração pública, direta e indireta. e) aplicação do mínimo exigido da receita resultante de impostos estaduais, compreendida a proveniente de transferências, na manutenção e desenvolvimento do ensino e nas ações e serviços públicos de saúde. E o Estado não intervirá em seus Municípios, nem a União nos Municípios localizados em Território Federal, exceto quando: I - deixar de ser paga, sem motivo de força maior, por dois anos consecutivos, a dívida fundada; II - não forem prestadas contas devidas, na forma da lei; III - não tiver sido aplicado o mínimo exigido da receita municipal na manutenção e desenvolvimento do ensino e nas ações e serviços públicos de saúde; IV - o Tribunal de Justiça der provimento a representação para assegurar a
} 
invasivo da intervenção e dos riscos à estabilidade política da nação a disciplina é rígida, como se vê do art. 36 da Constituição Federal e de rara, senão de quase nenhuma ocorrência, mesmo quando apontados pressupostos (a exemplo dos casos de não pagamento de precatórios alimentares por chefes do Poder Executivo em vários locais, sem a respectiva intervenção acontecendo, sendo verificada a prevalência do aspecto político diante do técnico).

\subsection{2 - Ação Popular.}

Ação popular (Lei Federal no 4.717/65), que permite a defesa dos interesses da população (direito difuso, portanto, de qualquer um) em relação ao patrimônio público e à moralidade administrativa sendo titular qualquer cidadão no pleno gozo de seus direitos políticos (que pode eleger e ser eleito). Visa prevenir, anular ou reprimir atos ou contratos administrativos ilegais e lesivos ao patrimônio público (Estado ou entidades de que ele participe), inclusive de autarquias, entidades paraestatais e outras subvencionadas por verbas oficiais e também lesivos à moralidade administrativa, ao meio ambiente e ao patrimônio histórico e cultural. O Ministério Público participa da ação como parte pública autônoma (além de custus legis) e pode concordar ou não com o pedido formulado, sendo legítimo e obrigatório prosseguir em substituição ao autor (se omisso ou desistente) apenas vedada a defesa do ato impugnado.

\subsection{3 - Ação Civil Pública}

Ação civil pública, com escopo de defender os direitos difusos e coletivos com titularidade para o Ministério Público e outros colegitimados, como a Defensoria Pública, a União, os Estados e Municípios, Autarquias, Empresas Públicas, Sociedades de Economia Mista, Fundações Públicas e associações de classe e sindicatos (estes últimos se atendidas determinadas especificações legais acerca de tempo de constituição e finalidade específica).

observância de princípios indicados na Constituição Estadual, ou para prover a execução de lei, de ordem ou de decisão judicial. 
Há previsões para áreas objetivas, tais como bens e direitos de valor artístico, estético, histórico, turístico e paisagístico, além de danos ao meio ambiente e ao consumidor e também de crianças e adolescentes carentes, além da cidadania e do ambiente do trabalho. Podem servir tanto contra atos já praticados pela administração pública, como visando suprir lacuna diante de omissão do poder público.

A ação civil pública tem sido, na prática, importante instrumento para o Ministério Público na proteção do patrimônio público e da probidade administrativa ${ }^{149}$, inclusive com a restituição de valores desviados do erário como recomposição do dano praticado por administradores ímprobos ${ }^{150}$.

\subsection{4 - Habeas Corpus.}

Habeas corpus, para os casos em que alguém sofrer ou estiver ameaçado de sofrer coação ou violência em sua liberdade de locomoção, por ilegalidade ou abuso de poder. Essencialmente protege o indivíduo diante de ameaça à sua liberdade física e corporal, sendo que qualquer pessoa, seja nacional ou não, em nome próprio ou de terceiros, admitida como desnecessária a presença de advogado (e mesmo o Ministério Público ou a Defensoria Pública), pode impetrá-lo. É preventivo (quando a pessoa está ameaçada de provável constrangimento ilegal) ou repressivo (se já consumada a violência ou coação corporal).

\subsection{5 - Habeas Data.}

Habeas data, nas hipóteses em que o indivíduo (trata-se de direito personalíssimo) pretende obter o conhecimento de informações relativas à sua pessoa e que

\footnotetext{
${ }^{149}$ Tendo o autor do trabalho atuado como titular da Promotoria de Justiça da Cidadania de São Paulo (nome alterado para Patrimônio Público em 2009) entre os anos de 1999 e 2011 cujas atribuições funcionais diziam respeito à defesa do patrimônio público e da probidade administrativa.

150 Estatística da Promotoria de Justiça do Patrimônio Público e Social da Capital - São Paulo, (http://www.pjc.sp.gov.br/noticiaspub1.asp?id=125, acesso em 16 de julho de 2012) aponta que entre 18 de dezembro de 1992 e 31 de dezembro de 2009, de 764 processo já extintos ou em andamento 211 haviam si do julgados procedentes, pendentes de recurso, para devolução ao erário de $\mathrm{R} \$ 8.263 .199 .529,21 ; 33$ estavam em execução para recuperação de $\mathrm{R} \$ 138.007 .790,31 ; 71$ haviam sido julgados improcedentes, não definitivamente (questionando $\mathrm{R} \$$ 1.005.938.857,76); 59 improcedentes definitivamente ( $\mathrm{R} \$ 1.894738 .417,16) ; 28$ extintos sem julgamento de mérito, não definitivo ( $\mathrm{R} \$ 45.380 .520,12) ; 25$ extintos definitivamente sem julgamento de mérito $(\mathrm{R} \$ 117.452 .089,61)$ e 337 ainda em andamento sem decisão, questionando a devolução de $\mathrm{R} \$ 22.739 .069 .242,96$. Totaliza a estatística 764 processos com $\mathrm{R} \$ 34.203 .786 .447,13$, sendo o montante questionado ainda em andamento de $\mathrm{R} \$ 32.191 .595 .940,36$.
} 
constem de registros ou bancos de dados de entidades governamentais ou de caráter público (tais como aquelas de serviço de proteção ao crédito) ou ainda para retificar os dados (caso não faça a opção pela retificação via processo sigiloso judicial ou administrativo). Pode impetrá-lo qualquer interessado (pessoa física ou jurídica) em face de pessoas políticas, entretanto sendo exigida a prova da recusa administrativa em fornecer a informação ${ }^{151}$.

3.4.2.4.3.6 - Mandado de Injunção.

Mandado de injunção, para as hipóteses em que houver falta de norma regulamentadora que torne inviável o exercício dos direitos e liberdades constitucionais e das prerrogativas inerentes à nacionalidade, à soberania e à cidadania $\left(\mathrm{CF}\right.$, art. $\left.5^{\circ} \mathrm{LXXI}\right)$. Apesar de não regulamentado, é possível se admiti-lo, embora com divergências doutrinárias quanto ao alcance. A jurisprudência do Supremo Tribunal Federal inclina-se por emprestar caráter declaratório e não constitutivo. Assim, seria aplicável somente a direitos subjetivos diante de direitos fundamentais previstos na Constituição sem possibilidade de serem efetivados diante de lacuna legislativa gerando impacto apenas para o caso concreto, isto é, com efeitos somente em favor do interessado. Fato é que não permite que o Poder Judiciário emita a norma legal até então inexistente e nem que obrigue o Poder respectivo a fazê-lo, mantido o respeito à independência dos Poderes.

\subsection{7 - Mandado de Segurança.}

Mandado de segurança, para proteger direito líquido e certo (não amparado por habeas corpus ou habeas data ou mandado de injunção) nas hipóteses em que alguém (ou uma coletividade), seja pessoa física ou jurídica, sofrer violação ou houver justo receio de sofrê-la e o responsável pela ilegalidade ou abuso de poder for autoridade pública ou agente de pessoa jurídica que detenha, sob qualquer pretexto legal, parcela de autoridade no exercício de atribuições do Poder Público. Implica reconhecer que o agente público contra quem a ação será impetrada deve estar investido de competência decisória, não sendo coator o simples agente que executa o ato questionado, assim como não o é o órgão

${ }^{151}$ STJ Súmula no 2 - 08/05/1990 - DJ 18.05.1990: "Não cabe o habeas data (CF, Art. 5’, LXXII, letra 'a') se não houve recusa de informações por parte da autoridade administrativa". 
ou a pessoa jurídica. A impugnação recai sobre o ato que lesa ou impede a fruição do direito do administrado ou a omissão de ato que deveria ter sido praticado e cuja ausência cause prejuízo ao administrado.

A lei ( $\left.{ }^{\circ} 12.016 / 09\right)$ excepciona (art.5 $5^{\circ}$ que não se concederá mandado de segurança quando se tratar de ato de que caiba recurso administrativo com efeito suspensivo, independente de caução; de decisão judicial da qual caiba recurso com efeito suspensivo e de decisão judicial transitada em julgado; especificidades que se somam àquelas exceções já previstas na própria Constituição ou se o direito pleiteado exigir dilação probatória (não for liquido e certo) ou não for individual (próprio) nem de classe, partido político, organização sindical ou associação (para o mandado de segurança coletivo).

\subsubsection{5 - Conclusões sobre o Controle Externo.}

Assim como no tema do controle interno, o controle externo específico, que trata da verificação dos atos da administração, tanto no que tange ao gerenciamento dos dinheiros e do patrimônio (bens etc.), também se vale de instrumentos próprios como as auditorias, inspeções, denúncias e representações.

Acontecem acompanhamentos, exames e julgamento de prestação de contas, de tomada de contas (regulares, normais, especiais e extraordinárias), das contas de governo e de registro de pessoal, além de outros como levantamentos e monitoramento de decisões $^{152}$.

Esta faceta do controle tem por objeto as licitações, os contratos, movimentação de pessoal, obras, patrimônio, sistemas informatizados, concessões de

\footnotetext{
${ }^{152}$ Francisco Chaves, in CHAVES, Francisco Eduardo Carrilho. Controle Externo da Gestão Pública. Niterói: Impetus, 2007. p. 37 anota que "A diferença entre o processo de tomada de prestação de contas está somente na denominação e em de quem são as contas. Denomina-se tomada de contas o processo de contas relativo à gestão dos responsáveis por unidades jurisdicionadas da administração federal direta, enquanto que a prestação de contas é o processo de contas relativo à gestão dos responsáveis por unidades jurisdicionadas da administração federal indireta e daquelas não classificadas como integrantes da administração direta federal. É o que define a IN-TCU no 47 de 2004, que estabelece normas de organização e apresentação de processos de tomada e prestação de contas. Em tempo, este mesmo normativo prevê que o processo de contas ordinárias é o 'processo de tomada ou prestação de contas organizado anualmente pelas unidades jurisdicionadas cujos responsáveis estão sujeitos à obrigação prevista no art. 70, parágrafo único da Constituição Federal'.”.
} 
aposentadorias, pensões, reformas, admissões de pessoal, arrecadação e renúncia de receitas, dívidas, convênios, privatizações, concessões de serviço, programas e políticas de governo e ainda qualquer outra despesa ou programação que impacte na atuação dos órgãos da administração pública direta e indireta.

Especificamente, a atuação do Tribunal de Contas é a que mais chama a atenção quando se aborda o controle externo, em especial com os critérios que serão adiante analisados acerca dos tipos de fiscalização (contábil, financeira, orçamentária, operacional e patrimonial), os fundamentos do art. 70 da Constituição Federal sobre legalidade, legitimidade e economicidade, e também o tema temporal em que o controle externo acontece em relação à ocorrência do objeto controlado (prévio, concomitante e posterior).

Cada vez mais é de se esperar que órgãos que visem auxiliar o pleno exercício da cidadania se antecipem às irregularidades ou práticas inadequadas de gestão, pretendendo evitar o dano ou reduzi-lo o quanto possível.

As irregularidades podem ter fundamento em desvios, desfalques, gestão fraudulenta, etc., vale dizer, com intenção do agente público em se valer de sua condição para obter vantagens pessoais em detrimento da legalidade e do bom funcionamento da coisa pública. Entretanto, também podem se originar em estruturas ou procedimentos inadequados adotados em órgãos, entidades ou programas de governo, isto é, em desarranjos não propositais e que merecem reavaliação para que possam se readequar à boa prática da gestão pública.

Finalmente, considerando-se que, assim como no controle interno, há no controle externo oportunidades temporais distintas para seu exercício, é de se dizer que o controle posterior é o mais comum e se revela nas prestações e tomadas de contas (sejam ordinárias ou extraordinárias); nos pareceres prévios sobre contas dos governos (federal) e territórios (uma vez que o julgamento é do Congresso Nacional); a concessão ou recusa de registro a atos de admissão de pessoal e concessão de aposentadoria, reforma ou pensão; auditorias em projetos e programas previstos na lei orçamentárias anual (em especial para avaliar resultados frente à eficácia, eficiência, efetividade e economicidade); conferência de aplicação de recursos repassados via convênio, acordo, ajuste ou outro instrumento 
semelhante; além do processamento e julgamento de infrações administrativas, dentre outros.

Já o controle concomitante ou simultâneo se faz, por exemplo ${ }^{153}$, quando o Tribunal de Contas acompanha a arrecadação de receita; fiscaliza cumprimento de normas da Lei de Responsabilidade Fiscal; fiscaliza a entrega aos destinatários dos recursos relativos às quotas do Fundo de Participação dos Estados do Distrito Federal e dos Municípios; verifica procedimentos licitatórios, contratos, convênios e programas de governo que se encontram em curso; acompanha e avalia processos de desestatização realizados pela administração pública e as concessões, permissões e autorizações de serviço público; também na observância e conferência dos recursos repassados por unidade da Federação a outro ente federado e também quando assinala prazo para que órgão ou entidade adote providências para corrigir a irregularidade apurada no correr da execução dos serviços.

O controle prévio é o de maior dificuldade, posto que se antecipar às ações exige, além de expertise no trato do assunto, amplo acesso a informações e dados e o mais direto possível, além de capacidade de analisá-los antes da ocorrência do ato controlado. Não é possível ao Tribunal de Contas quebrar sigilo bancário, fiscal ou telefônico, existindo, assim, óbices na fiscalização ${ }^{154}$. Neste ponto, torna-se importante o trabalho conjugado das instituições fiscalizadoras, na medida em que uma parceria entre o Tribunal de Contas e o Ministério Público poderia permitir o melhor acesso às informações pretendidas. Via de regra são denúncias ou representações enviadas aos órgãos fiscalizadores que permitem que se faça um controle prévio. Outros instrumentos podem ser as medidas cautelares; as recomendações; avaliações prévias de editais; a sustação de

${ }^{153}$ CHAVES, Francisco Eduardo Carrilho. Controle Externo da Gestão Pública. Niterói-RJ. Ed. Impetus. 2007. p.41.

154 "A Lei Complementar 105, de 10-1-2001, não conferiu ao Tribunal de Contas da União poderes para determinar a quebra do sigilo bancário de dados constantes do Banco Central do Brasil. O legislador conferiu esses poderes ao Poder Judiciário (art. $3^{\circ}$ ), ao Poder Legislativo Federal (art. $4^{\circ}$ ), bem como às comissões parlamentares de inquérito, após prévia aprovação do pedido pelo Plenário da Câmara dos Deputados, do Senado Federal ou do plenário de suas respectivas Comissões Parlamentares de Inquérito ( $\$$ $1^{\circ}$ e $2^{\circ}$ do art. $4^{\circ}$ ). Embora as atividades do TCU, por sua natureza, verificação de contas e até mesmo o julgamento das contas das pessoas enumeradas no art. 71, II, da CF, justifiquem a eventual quebra de sigilo, não houve essa determinação na lei específica que tratou do tema, não cabendo a interpretação extensiva, mormente porque há princípio constitucional que protege a intimidade e a vida privada, art. $5^{\circ}, X, d a C F, n o$ qual está inserida a garantia ao sigilo bancário." (MS 22.801, Rel. Min. Menezes Direito, julgamento em 17-12-2007, Plenário, DJE de 14-3-2008.) No mesmo sentido: MS 22.934, Rel. Min. Joaquim Barbosa, julgamento em 17-4-2012, Segunda Turma, DJE de 9-5-2012; MS 22.934, Rel. Min. Joaquim Barbosa, julgamento em 17-4-2012, Segunda Turma, Informativo 662. 
atos ou contratos antes de sua execução e ainda a assinatura de determinações (que visam evitar que irregularidades já detectadas em processo distinto de fiscalização, voltem a se repetir).

Fato é que, a existência das duas modalidades de controle, o interno e o externo permite, em tese, que a sociedade tenha plena oportunidade de ver os agentes públicos (seja enquanto indivíduos, seja representando distintos órgãos da administração pública) devidamente observados, orientados e até mesmo punidos no exercício de seus atos, fazendo com que a gestão do patrimônio público possa estar cada vez mais em obediência aos parâmetros legais, respeitando os liames para com o Estado e para com sua finalidade e ao mesmo tempo atendendo as expectativas do grupo social a que deve servir.

\section{5 - Fiscalização.}

3.5.1 - Escopo.

Cabe dizer, inicialmente, reiterar que o ato de fiscalizar não envolve apenas avaliação técnico-procedimental, ou seja, a correção do procedimento técnico ou formal, mas também a repercussão jurídico-legal do ato fiscalizado (vale dizer a obediência aos princípios já mencionados), e o bom e regular emprego do patrimônio e dos dinheiros públicos.

Visa a fiscalização avaliar e medir a eficácia dos controles internos existentes, com escopo de detectar, prevenir e orientar sobre possíveis falhas ou irregularidades ou mesmo ilegalidades, para que a administração possa promover otimização nos quesitos da economicidade, eficiência e qualidade dos serviços que realiza, sendo que a atuação se dá por meio de auditorias cujos resultados servem como elementos para o julgamento das contas a serem prestadas ao final do exercício financeiro, com os devidos reflexos da atividade patrimonial.

A fiscalização deve ser o mais abrangente possível, posto que o sistema, como um todo tem por objeto estabelecer ação de controle que envolva todas as atividades da organização estatal, desde o plano governamental até a realização dos seus objetivos, mediante procedimentos técnicos de avaliação (já vistos anteriormente). 
Entretanto, tal afirmação pode guardar certa característica de subjetividade, razão pela qual necessário se faz que parâmetros legais ou doutrinários, sejam utilizados em seu estudo.

\subsection{2 - Quem deve ser fiscalizado.}

A Constituição Federal com a redação do art.70 aponta parâmetros ao dizer que prestará contas qualquer pessoa física ou jurídica, pública ou privada, que utilize, arrecade, guarde, gerencie ou administre dinheiros, bens e valores públicos ou pelos quais a União responda, ou que, em nome desta, assuma obrigações de natureza pecuniária.

O texto refere a União, mas, certamente, deve ser entendido que todos os demais entes estão inseridos no mesmo contexto, até pela própria natureza de federalismo da nação (aspecto já abordado no início do trabalho).

Assim, é buscado um conhecimento sobre o comportamento do gestor público, emitindo-se juízo de valor sobre o que foi encontrado (julgamento de contas prestadas). Há objetivo de se manter sindicância permanente sobre a administração de bens e dinheiros públicos (considerado o patrimônio público) para evitar sua malversação criando estabilidade comportamental na gerência e administração das finanças e bens estatais na busca do bem comum.

O sistema deve alcançar todas as unidades da administração direta e indireta, bem como qualquer pessoa física ou jurídica, pública ou privada que proceda a ações envolvendo a utilização, arrecadação, guarda, gerência ou administração de dinheiros, bens e valores públicos.

Relembrando a divisão administrativa do setor público, já abordada no Capítulo ${ }^{\mathrm{o}} 2$, o Decreto-Lei 200/67 (art. 4º, incisos I e II e art. 5º, incisos I, II e III) e a Lei 8.490/92 (arts. 15 e 29) apresentam a classificação de administração direta e indireta e ainda que Celso Antonio Bandeira de Melo ${ }^{155}$ diga que “... o modelo é inapto para

\footnotetext{
${ }^{155}$ BANDEIRA DE MELLO, Celos Antonio. Curso de Direito Administrativo. 4aed. São Paulo: Malheiros,
} 1993 
descortinar todas as modalidades pelas quais se desempenham atividades administrativas públicas", é de se firmar a importância da separação, e mesmo admitindo-se que o modelo definidor seja insuficiente, nada afasta o fato de que tanto uma como outra será objeto de fiscalização.

Consta do Decreto-Lei $n^{\circ}$ 200/67 que as entidades compreendidas na Administração Indireta vinculam-se ao Ministério em cuja área de competência estiver enquadrada sua principal atividade. Assim, também para efeito de Estados e Municípios, será vinculada à Secretaria respectiva, indicando o caminho a ser seguido no processo de fiscalização.

A providência de inserir na Constituição Federal de 1988 o tema foi saudável, já que na Constituição de 1967 o controle prévio foi passado ao sistema de auditorias e aquela Carta deixou de fazer referência à administração indireta e a entes privados, motivando entendimento de que as sociedades de economia mista e empresas públicas não estariam submetidas ao controle externo do Tribunal de Contas. Somente com a edição das Leis Federais $n^{\circ}$ 6.233/75 e 6.525/78 aquelas entidades foram inseridas no sistema de fiscalização então implantado.

Interessante abordagem sobre quem poderia ser objeto de fiscalização também se encontra na Lei de Improbidade Administrativa, conforme mencionado em tópico anterior (2.1.1.6.1).

Quando a Lei $\mathrm{n}^{\circ} 8.429 / 92$ indica quem responde por ato de improbidade administrativa, de certa forma inclui todas aquelas pessoas no rol de quem deve ser fiscalizado em suas ações, afinal decorre logicidade no fato de que se alguém tem dever de transparência e de atendimento aos princípios apresentados no Caput do art. 37 da Constituição Federal, também tem o dever de prestar contas.

Conforme se infere, devem manter-se probos para efeito de fiscalização qualquer agente público, servidor ou não, da administração direta, indireta ou fundacional de qualquer dos Poderes da União, dos Estados, do Distrito Federal, dos Municípios, de Território, de empresa incorporada ao patrimônio público ou de entidade para cuja criação 
ou custeio o erário haja concorrido ou concorra com mais de cinquenta por cento do patrimônio ou da receita anual.

Também aqueles que praticam ações diante de patrimônio de entidade que receba subvenção, benefício ou incentivo, fiscal ou creditício, de órgão público bem como daquelas para cuja criação ou custeio o erário haja concorrido ou concorra com menos de cinquenta por cento do patrimônio ou da receita anual, limitando-se, nestes casos, a sanção patrimonial à repercussão do ilícito sobre a contribuição dos cofres públicos.

Reputa-se, então, para efeitos da Lei $n^{\circ} 8.429 / 90$, e, portanto, sujeitos à análise de sua conduta sob a ótica da probidade, que é agente público todo aquele que exerce, ainda que transitoriamente ou sem remuneração, por eleição, nomeação, designação, contratação ou qualquer outra forma de investidura ou vínculo, mandato, cargo, emprego ou função nas entidades acima mencionadas.

E também se considera que as mesmas disposições são aplicáveis, no que couber, àquele que, mesmo não sendo agente público, induza ou concorra para a prática do ato ou dele se beneficie sob qualquer forma direta ou indireta.

Pode-se afirmar, interpretando de forma abrangente, que mesmo o particular que trata de questões patrimoniais junto à administração pública deve prestar contas na medida de sua participação e ainda ser sujeito de fiscalização (externa, principalmente). Um empreiteiro que tenha vencido licitação para construir uma usina de compostagem em determinado município receberá seu pagamento do erário e assim, aquele patrimônio que está se incorporando ao setor público, legitima que, no âmbito do contrato assinado com a municipalidade seja o construtor fiscalizado (medições de obra, material adotado etc). Deverá mesmo demonstrar que a empresa é sólida para arcar com obra daquele vulto.

Assim como a questão da probidade traça parâmetros para o tema da fiscalização outra referência neste quesito se apresenta com a indagação sobre se as contas devem ser prestadas por pessoas físicas ou jurídicas, ou ambas ou se poderia algum ente vinculado à administração Pública estar isento da prestação de contas e a resposta é no sentido de que se qualquer dúvida existir, a interpretação deve ser a de maior amplitude, vale dizer, tanto pessoas físicas como jurídicas estão sujeitas à fiscalização e nenhum ente 
ou pessoa naquelas condições pode estar isento da prestação de contas. Logo, sempre que houver envolvimento de patrimônio público, a exegese deverá ser em favor do erário e, portanto, acontecerá a exigência da prestação de contas e a possibilidade da fiscalização.

Da mesma forma, para efeito de otimização da questão da prestação de contas, deve haver uma disciplina quanto ao momento em que a fiscalização deve acontecer no que diz respeito tanto à gestão do patrimônio como dos demais elementos relativos à administração pública.

Portanto, para que seja possível a busca da excelência no processo fiscalizatório, há uma forma e um sistema de controle e um regramento acerca dos poderes e órgãos envolvidos, afinal quem controla também deve ter seus controles.

Neste sentido, cabe abordar os tipos de fiscalização.

\subsection{3 - Tipos de Fiscalização.}

Como já foi referido, a Constituição Federal na Seção IX do Capítulo I, quando disciplina o Poder Legislativo trata também do sistema de fiscalização da atividade financeira do Estado, e de sua estrutura.

É necessário que se tenha uma divisão formalizada para que a fiscalização possa ser exercida, de tal forma que os aspectos distintos da atividade do Estado sejam tratados de modo singular, permitindo a obtenção do melhor resultado quando da atividade fiscalizadora.

Diante da afirmação anterior de que não se limita somente à uma avaliação eminentemente técnica ou procedimental (visto que não somente deve ser verificada a correção do procedimento técnico), mas também a repercussão jurídico-legal do ato fiscalizado, o art. 70 da Constituição Federal determina a obrigatoriedade de obediência aos princípios da legalidade, legitimidade e economicidade. 
Vale dizer que, por exemplo, uma despesa pode ter o registro contábil regular, mas ser considerada ilegal ou ilegítima ${ }^{156}$.

Assim, o sistema se subdivide em fiscalização contábil, financeira, orçamentária, operacional e patrimonial e não se limita a uma simples técnica, mas muito mais do que isso, se define por uma ação que utiliza e analisa a técnica, tendo sua atuação direcionada para uma atividade jurídica de avaliação, visando verificar o bom e regular emprego dos valores públicos.

Reafirma-se que pretende o sistema de fiscalização buscar o estabelecimento de uma ação de controle que envolva todas as atividades da organização estatal, desde o planejamento até a efetiva realização dos objetivos, perpassando pela avaliação e medida de eficácia dos controles internos existentes para detectar, prevenir e orientar sobre possíveis falhas irregularidades ou ilegalidades e ainda permitir à Administração promover maior eficiência e qualidade dos serviços que realiza.

Serve, ainda, para viabilizar, por meio das conclusões decorrentes de uma ação continuada de controle, o julgamento das contas que devem ser prestada pelos gestores públicos ${ }^{157}$.

Vejamos o significado de cada uma delas.

\subsubsection{1 - Fiscalização Contábil}

A Lei $n^{\circ} 4.320$ de 17 de março de 1964 estatui normas gerais de direito financeiro e controle dos orçamentos e balanços da União, dos Estados e Municípios e do Distrito Federal.

Estabelece no art. $2^{\circ}$ que "A Lei do Orçamento conterá a discriminação da receita e despesa de forma a evidenciar a política econômica financeira e o programa de trabalho do Governo, obedecidos os princípios de unidade, universalidade e anualidade”.

\footnotetext{
${ }^{156}$ MILESKI, Helio Saul. O Controle da Gestão Pública. São Paulo: RT, 2003 p.239
}

${ }^{157}$ MILESKI, Helio Saul. O Controle da Gestão Pública. São Paulo: RT, 2003 p.240 
Em seguida indica que integram a Lei de Orçamento o sumário geral da receita por fontes e da despesa por funções do Governo e diversos quadros como o demonstrativo da Receita e Despesa segundo as Categorias Econômicas, o quadro discriminativo da receita por fontes e respectiva legislação e o quadro das dotações por órgãos do Governo e da Administração.

Todos os atos da atividade financeira do Estado devem ser registrados pela contabilidade, obedecendo rigorosamente a ordem cronológica. O objetivo da contabilidade é captar, registrar, acumular, resumir e interpretar fenômenos que afetam as situações orçamentárias, financeiras e patrimoniais das entidades do Direito Público Interno $^{158}$.

Não há na Doutrina, uma definição simples do que seja Contabilidade, entretanto, é possível dizer que três podem ser as perspectivas para seu entendimento ${ }^{159}$ :

Pela primeira é um ramo do conhecimento que compreende um conjunto de conhecimentos e princípios fundamentais que se constituem em bases teóricas e conceituais de ordens operacional, econômica e financeira, necessárias ao processo de informar usuários sobre a evolução do patrimônio de uma entidade, onde patrimônio é o conjunto de elementos necessários à existência da entidade, formado pelos bens, direitos e obrigações; entidade é uma organização qualquer constituída para o desenvolvimento de uma atividade econômica seja na forma de pessoa física ou jurídica; e usuário é toda pessoa física ou jurídica que necessita de informação para a tomada de decisão.

Na segunda perspectiva, com visão funcional, é um conjunto sistemático de procedimentos que identifica, registra, mensura, acumula, resume, demonstra e interpreta os fenômenos que afetam o patrimônio de uma entidade, evidenciando-os na forma de informações aos usuários.

A terceira percebe o ponto de vista organizacional, sendo que se define como uma unidade (interna ou externa) responsável pelo processo de identificação,

158 KOHAMA, H. Contabilidade Pública: teoria e prática. 10ª Ed. São Paulo, Atlas, 2006.

159 BORINELLI, Márcio Luiz; SOUZA, Bruno Carlos de e PIMENTEL, Renê Coppe. FIA - Fundação Instituto de Administração - Apostila de finanças e contabilidade - Curso de Desenvolvimento Profissional para Executivos. 2010. 
registro, mensuração, acumulação, resumo, demonstração e interpretação dos fenômenos que afetam o patrimônio da organização, com vistas a evidenciá-los na forma de informações aos usuários.

Assim, considera-se que os objetivos da Contabilidade, conforme as perspectivas analisadas são: a) servir de base de sustentação para todas as discussões teóricas e práticas que envolvam o tema da Contabilidade, sempre com vistas ao aprimoramento do processo informacional; b) prover os usuários da Contabilidade com informações de ordens operacional, econômica e financeira sobre os fenômenos que afetam o patrimônio de uma entidade, subsidiando o processo de tomada de decisões e c) administrar e executar o processo de geração de informações de ordens operacional, econômica e financeira sobre os fenômenos que afetam o patrimônio da organização, subsidiando o processo de tomada de decisões.

Mesmo que a definição parta de um pensamento de administração privada, é possível transportá-lo para a ótica da Administração Pública, onde deve ser entendido que cada entidade pode ser uma unidade individualizada de uma repartição simples (almoxarifado da sala de lanches de uma Secretaria Municipal) ou mesmo toda uma entidade (Tribunal de Contas ou Ministério Público) ou ainda um Poder (Judiciário, por exemplo).

A contabilidade pública, na verdade, é uma das subdivisões da Contabilidade, aplicada a diferentes tipos de atividades de entidades distintas. O campo de atuação é o das pessoas jurídicas de Direito Público interno.

Quaisquer atividades de tais entidades, desde o plano mais simples até o mais complexo, deve estar evidenciada com as informações detalhadas em escriturações próprias, proporcionando aos usuários (que podem ser desde um mandatário que precisa conhecer dados para escolha da política pública a ser implementada ou um fiscal do Tribunal de Contas, para permitir sua análise dos dados colhidos) a oportunidade de conhecimento das informações obtidas.

A Administração Pública dispõe de sistemas de contas independentes para cada agrupamento. São chamados de sistemas (a) orçamentário - que registra o orçamento 
e sua execução, permite a comparação entre o orçado e o executado e traz o balanço orçamentário, (b) financeiro - que registra as informações sobre as entradas e saídas de numerários e a posição das disponibilidades no início e no final do exercício, permite a apuração do resultado financeiro e traz o balanço financeiro), (c) patrimonial - que apresenta informações sobre a composição do patrimônio e suas variações em determinado período de tempo, permite verificar as variações na situação patrimonial líquida e traz o balanço patrimonial e demonstração das variações patrimoniais e (d) o sistema de compensação - com informações sobre fatores que poderão vir a afetar o patrimônio da entidade de forma ativa ou passiva.

São registrados de forma analítica e sintética: escrituração analítica compreende um diário analítico da receita orçamentária; um da despesa prevista, empenhada e realizada; um do movimento extraorçamentário; um do movimento bancário e diário de caixa.

A sintética traz Diário Geral e Razão Geral, neste sendo extraídos os balancetes de verificação e ao fim do exercício os balanços de cada sistema (utilizado o método das partidas dobradas, conforme art. 86 da Lei $\mathrm{n}^{\circ}$ 4.320/64: “A escrituração sintética das operações financeiras e patrimoniais efetuar-se-á pelo método das partidas dobradas - que indica registro por meio de débito e crédito, apresentando balanço com ativo, passivo e patrimônio líquido”.).

O Decreto 93.872/86 diz no art.136: “A contabilidade deverá evidenciar, em seus registros, o montante dos créditos orçamentários vigentes, a despesa empenhada e a despesa realizada à conta dos mesmos créditos, as dotações disponíveis e os recursos financeiros programados "160.

Também o regime contábil prevê (conforme art.35 da Lei ${ }^{\circ}$ 4.320/64) que pertencem ao exercício financeiro as receitas nele arrecadadas e as despesas nele legalmente empenhadas.

Cabe uma breve abordagem sobre regimes de competência contábil:

\footnotetext{
${ }^{160}$ PISCITELLI, Roberto Bocasccio; TIMBÓ, Maria Zulene Farias. Contabilidade Pública. São Paulo: Atlas, $10^{\mathrm{a}}$ Ed. 2009. p.303.
} 
Demonstrações contábeis são preparadas e apresentadas para auxiliar os usuários das informações na avaliação das posições financeira e patrimonial assim como as perspectivas futuras. Isto é, espelhar uma realidade e permitir a projeção da nova realidade. Para técnica de registros há os chamados regimes, que são de dois tipos: caixa ou competência.

As receitas arrecadadas são registradas pelo "regime de caixa", posto que este privilegia o ingresso dos valores e a realização financeira efetiva. Já as despesas legalmente empenhadas se valem do "regime de competência" uma vez que ele privilegia a ocorrência do evento econômico ao invés de considerar apenas o pagamento da transação (o que é necessário para evidenciar o patrimônio efetivo e o resultado das operações, pois considera não somente as obrigações pagas, como as que deverão ser liquidadas no futuro)

Segundo a disciplina da Lei $n^{\circ}$ 4.320/64 (artigos 34 e seguintes), o exercício financeiro coincidirá com o ano civil e pertencem ao exercício financeiro as receitas nele arrecadadas e as despesas nele legalmente empenhadas, sendo que se consideram 'Restos a Pagar' as despesas empenhadas, mas não pagas até o dia 31 de dezembro distinguindo-se as processadas das não processadas.

A contabilidade empresarial se vale do regime de competência (em virtude do pressuposto da continuidade empresarial), mas na contabilidade pública, há regime misto, na prática. O art.50, inciso II da Lei de Responsabilidade Fiscal (Lei Complementar $\left.n^{\circ} 101 / 2000\right)$ indica que será apurado em caráter complementar o resultado dos fluxos financeiros pelo regime de caixa.

Esta mesma Lei estabelece (art. 50 e seguintes) que além de obedecer às demais normas de contabilidade pública, a escrituração das contas públicas observará outros comandos, a saber: a disponibilidade de caixa constará de registro próprio, de modo que os recursos vinculados a órgão, fundo ou despesa obrigatória fiquem identificados e escriturados de forma individualizada; a despesa e a assunção de compromisso serão registradas segundo o regime de competência, apurando-se, em caráter complementar, o resultado dos fluxos financeiros pelo regime de caixa; as demonstrações contábeis compreenderão, isolada e conjuntamente, as transações e operações de cada órgão, fundo 
ou entidade da administração direta, autárquica e fundacional, inclusive empresa estatal dependente; as receitas e despesas previdenciárias serão apresentadas em demonstrativos financeiros e orçamentários específicos; as operações de crédito, as inscrições em Restos a Pagar e as demais formas de financiamento ou assunção de compromissos junto a terceiros, deverão ser escrituradas de modo a evidenciar o montante e a variação da dívida pública no período, detalhando, pelo menos, a natureza e o tipo de credor e a demonstração das variações patrimoniais dará destaque à origem e ao destino dos recursos provenientes da alienação de ativos.

No caso das demonstrações conjuntas, excluir-se-ão as operações intragovernamentais, enquanto que a Administração Pública deverá manter sistema de custos que permita a avaliação e o acompanhamento da gestão orçamentária, financeira e patrimonial.

Entretanto, apesar do que foi dito quanto às despesas se valerem do "regime de competência" há notícia de enfoques diferentes quanto à sua apropriação. A Secretaria do Tesouro Nacional (STN) considera como execução orçamentária da despesa a ocorrência do estágio da liquidação, efetivado ou não o seu respectivo pagamento e, na apuração do resultado primário se vale do regime de caixa para as receitas e despesas, inclusive as extraorçamentárias. Referem Roberto Piscitelli e Maria Zulene Timbó ${ }^{161}$ que o reconhecimento orçamentário da despesa se dá desde o primeiro estágio e o da receita somente ocorre com o segundo estágio, acentuando caráter conservador da contabilidade pública. Não se contabiliza o 'direito' ao recebimento, exceto quando a receita não recebida for inscrita como Dívida Ativa. Afirmam eles que a tradição cultural e política do Brasil não confere à atuação do Estado em relação aos inadimplentes e sonegadores a necessária credibilidade a ponto de incorporar a seu patrimônio os direitos inerentes ao exercício de seu poder de policia (mencionam que a Secretaria da RF informou que no final de 2007, existiam $\mathrm{R} \$ 199$ bilhões de débitos em cobrança e $\mathrm{R} \$ 423$ bilhões com exigibilidade suspensa).

Vale referir dispositivos da Lei $n^{\circ}$ 4.320/64 acerca da fiscalização contábil.

${ }^{161}$ PISCITELLI, Roberto Bocasccio; TIMBÓ, Maria Zulene Farias. Contabilidade Pública SP. Atlas, $10^{\mathrm{a}}$ Ed. 2009, p.15 (referindo os relatórios resumidos de execução orçamentária, financeira e patrimonial de 2009). 
Segundo o art. 83 e seguintes, a contabilidade evidenciará perante a Fazenda Pública a situação de todos quantos, de qualquer modo, arrecadem receitas, efetuem despesas, administrem ou guardem bens a ela pertencentes ou confiados e ressalvada a competência do Tribunal de Contas ou órgão equivalente, a tomada de contas dos agentes responsáveis por bens ou dinheiros públicos será realizada ou superintendida pelos serviços de contabilidade.

Os serviços de contabilidade serão organizados de forma a permitirem o acompanhamento da execução orçamentária, o conhecimento da composição patrimonial, a determinação dos custos dos serviços industriais, o levantamento dos balanços gerais, a análise e a interpretação dos resultados econômicos e financeiros, devendo existir controle contábil dos direitos e obrigações oriundos de ajustes ou contratos em que a administração pública for parte.

Os débitos e créditos serão escriturados com individuação do devedor ou do credor e especificação da natureza, importância e data do vencimento, quando fixada, devendo ser evidenciados todos os fatos ligados à administração orçamentária, financeira patrimonial e industrial além do montante dos créditos orçamentários vigentes, a despesa empenhada e a despesa realizada, à conta dos mesmos créditos, e as dotações disponíveis.

O registro contábil da receita e da despesa far-se-á de acordo com as especificações constantes da Lei de Orçamento (renovada a cada ano) e dos créditos adicionais, sendo que a dívida flutuante compreende os restos a pagar, excluídos os serviços da dívida; os serviços da dívida a pagar; os depósitos e os débitos de tesouraria.

O registro dos Restos a Pagar far-se-á por exercício e por credor distinguindo-se as despesas processadas das não processadas e todas as operações de que resultem débitos e créditos de natureza financeira, não compreendidas na execução orçamentária, serão também objeto de registro, individuação e controle contábil.

Os resultados gerais do exercício serão demonstrados no Balanço Orçamentário, no Balanço Financeiro, no Balanço Patrimonial e na Demonstração das Variações Patrimoniais. 
O Balanço Orçamentário demonstrará as receitas e despesas previstas em confronto com as realizadas; o Balanço Financeiro demonstrará a receita e a despesa orçamentárias bem como os recebimentos e os pagamentos de natureza extraorçamentária, conjugados com os saldos em espécie provenientes do exercício anterior, e os que se transferem para o exercício seguinte.

Os Restos a Pagar do exercício serão computados na receita extraorçamentária para compensar sua inclusão na despesa orçamentária.

Por sua feita, a Demonstração das Variações Patrimoniais evidenciará as alterações verificadas no patrimônio, resultantes ou independentes da execução orçamentária, e indicará o resultado patrimonial do exercício.

Obrigatoriamente, o Balanço Patrimonial demonstrará o Ativo Financeiro; o Ativo Permanente; o Passivo Financeiro; o Passivo Permanente; o Saldo Patrimonial e as Contas de Compensação.

Entende-se por Ativo Financeiro aquele que compreenderá os créditos e valores realizáveis independentemente de autorização orçamentária e os valores numerários; por Ativo Permanente o que compreenderá os bens, créditos e valores, cuja mobilização ou alienação dependa de autorização legislativa; por Passivo Financeiro a compreensão das dívidas fundadas e outros pagamentos que independam de autorização orçamentária e por Passivo Permanente a compreensão das dívidas fundadas e outras que dependam de autorização legislativa para amortização ou resgate.

Nas contas de compensação serão registrados os bens, valores, obrigações e situações não compreendidas nos parágrafos anteriores e que, imediata ou indiretamente, possam vir a afetar o patrimônio.

Conforme o art. 106 da Lei $\mathrm{n}^{\mathrm{o}}$ 4.320/64, a avaliação dos elementos patrimoniais deverá apresentar registro dos débitos e créditos, bem como os títulos de renda, pelo seu valor nominal, feita a conversão, quando em moeda estrangeira, à taxa de câmbio vigente na data do balanço; dos bens móveis e imóveis, pelo valor de aquisição ou 
pelo custo de produção ou de construção e os bens de almoxarifado, pelo preço médio ponderado das compras.

Os valores em espécie, assim como os débitos e créditos, quando em moeda estrangeira, deverão figurar ao lado das correspondentes importâncias em moeda nacional e as variações resultantes da conversão dos débitos, créditos e valores em espécie serão levadas à conta patrimonial, sendo possível a reavaliação de bens móveis e imóveis.

Especificamente, a contabilidade patrimonial está prevista no Capítulo III da Lei $n^{\circ} 4.320 / 64$ e consta que deverá existir registro analítico de todos os bens de caráter permanente, com indicação dos elementos necessários para a perfeita caracterização de cada um deles e dos agentes responsáveis pela sua guarda e administração (art. 94). Os artigos 94 a 100 disciplinam elementos patrimoniais distintos, sendo os bens de caráter permanente, os móveis e imóveis, a dívida fundada e o saldo patrimonial.

Mais adiante será visto o tema da abrangência da expressão 'patrimônio público' entretanto, é certo que vai além dos bens materiais ou financeiros. Para a contabilidade importa observar a necessidade de se trabalhar com distintos sistemas para efeito de registros, dentre eles o patrimonial, no qual se estabelecem as contas patrimoniais que registram o ativo e o passivo permanente, os bens (exceto dinheiros), valores (ações, títulos, joias), a dívida pública, a dívida ativa, as variações patrimoniais ativas e passivas, decorrentes ou não da execução orçamentária e o saldo patrimonial $^{162}$.

Observa-se que os registros contábeis permitem grande auxílio nos demais tipos de fiscalização, na medida em que servem de instrumento para análises financeiras, orçamentárias, patrimoniais e operacionais.

Vale mencionar a existência de um movimento global no sentido de se uniformizar procedimentos contábeis e o Brasil, inserido cada vez mais no contexto, vem se adaptando.

162 MOTA, Francisco Glauber Lima. Contabilidade aplicada à Administração Pública. $6^{\mathrm{a}}$ ed. Brasilia: Vestcon, 2003. 
A Secretaria do Tesouro Nacional editou com a Secretaria do Orçamento Federal a Portaria Conjunta (STN/SOF) n 02 de 06 de agosto de 2009, com o título "Manual de Contabilidade Aplicada ao Setor Público" que então era facultativa para o ano de 2010, mas já obrigatória para o ano de 2011 e demais a seguir.

Menciona o texto da Portaria que a padronização do registro contábil possibilitará aos usuários acesso a informações consistentes e tempestivas para a tomada de decisão e que a uniformização deve abranger atos e fatos no âmbito do setor público dentre os quais se destaca a gestão do orçamento público.

E ainda refere que se apresenta em consonância com as "Orientações Estratégicas para a Contabilidade aplicada ao Setor Público no Brasil", documento elaborado pelo Conselho Federal de Contabilidade com vistas à: a) convergência aos padrões internacionais de contabilidade aplicados ao setor público; b) implementação de procedimentos e práticas contábeis que permitam o reconhecimento, a mensuração, a avaliação e a evidenciação dos elementos que integram o patrimônio público; c) implantação de sistema de custos no âmbito do setor público brasileiro; d) melhoria das informações que integram as Demonstrações Contábeis e os Relatórios necessários à consolidação das contas nacionais; e) possibilitar a avaliação do impacto das políticas públicas e da gestão, nas dimensões social, econômica e fiscal, segundo aspectos relacionados à variação patrimonial.

O referido documento estabelece três grandes diretrizes estratégicas, desdobradas em macro-objetivos, que contribuem para o desenvolvimento da Contabilidade Aplicada ao Setor Público, cujas implantações deverão ocorrer a partir da celebração de parcerias entre o Conselho Federal de Contabilidade (CFC) e instituições que atuam, de forma direta ou indireta, com a Contabilidade aplicada ao Setor Público.

São elas: primeira: promover o 'Desenvolvimento Conceitual da Contabilidade Aplicada ao Setor Público no Brasil'; segunda: estimular a 'Convergência às Normas Internacionais de Contabilidade aplicadas ao Setor Público (IPSAS)’ e terceira: fortalecer institucionalmente a 'Contabilidade aplicada ao Setor Público'. 
Há uma distinção a ser mencionada que diz respeito aos termos 'patrimônio público' e 'patrimônio contábil' dos órgãos entidades da Administração Pública. Nem sempre coincidem. Os bens de uso comum (art. 99 do Código Civil) muito embora formados com recursos públicos e com uso deles para sua manutenção, não compõem formalmente o patrimônio contábil (que constitui o objeto da Contabilidade). Tal patrimônio está associado estritamente ao respectivo órgão ou entidade.

Assim, por exemplo, "o direito de transportar mercadoria de uma entidade numa via expressa, embora um benefício, não pode ser considerado como Ativo, pois se trata de direito concedido a todos, não sendo exclusivo para a entidade" ${ }^{, 163}$. Portanto, o direito para ter relevância contábil deve ser da entidade. Os equipamentos de uma praça de um Município, embora sejam patrimônio público, não integram o patrimônio contábil da respectiva Prefeitura, não sendo incorporados a seu Ativo ou tombados (na acepção contábil), não sendo ainda inventariados, ${ }^{164}$ o que não significa que não sejam objeto de fiscalização, mas sim que esta acontecerá sob outro item, distinto do contábil.

Finalmente, tendo o planejamento e o controle como funções básicas da Contabilidade, deve levar ela em conta critérios de eficiência (uso dos recursos), eficácia (consecução dos objetivos) e efetividade (satisfação das necessidades do ponto de vista do usuário, do contribuinte, do cidadão), de tal forma que a sistematização e a formalização das informações, em especial dos órgãos e entidades que integram a Administração Pública sejam indispensáveis ao acompanhamento das ações das organizações do Estado e ao julgamento público da atuação de seus dirigentes e responsáveis.

E ainda com a presença das qualidades ou atributos da tempestividade, integralidade e confiabilidade, que caracterizam as informações contábeis, conforme explicado por Iudícibus ${ }^{165}$, onde Tempestividade diz respeito, em essência, ao fato de que as informações e demonstrações contábeis, para serem úteis para os usuários, devem ser editadas em tempo hábil para que o tomador de decisões possa extrair o máximo de utilidade da informação para os propósitos a que se destina. De pouco adianta dispor de uma Demonstração de Resultados de uma Entidade, absolutamente perfeita e

\footnotetext{
${ }^{163}$ IUDÍCIBUS, Sérgio et al. Contabilidade intermediária.São Paulo: Atlas, 1981.

${ }^{164}$ PISCITELLI, Roberto Bocasccioi e TIMBÓ, Maria Zulene Farias. Contabilidade Pública SP. Atlas, $10^{\mathrm{a}}$ Ed. 2009, p.11/12

${ }^{165}$ IUDÍCIBUS, Sérgio de, Teoria da contabilidade, 7 ed. São Paulo: Atlas, 2004, p.85
} 
extremamente detalhada, somente um ano após a data do término do exercício social que contempla.

A Integralidade (Completeza, segundo o Conselho Federal de Contabilidade, incluída no Atributo de Confiabilidade) diz respeito ao fato de a informação contábil ter de compreender todos os elementos relevantes e significativos sobre o que se pretende revelar ou divulgar, como transações, previsões, análises, demonstrações, opiniões ou outros elementos. E a Confiabilidade é a qualidade (atributo) que faz com que o usuário aceite a informação contábil e a utilize como base para suas decisões, tornandose, assim, um elo fundamental entre o usuário e a própria informação. Para serem confiáveis, as informações contábeis, além de sua Integridade ou Completeza, devem ser baseadas nos Princípios Fundamentais de Contabilidade (Postulados, Princípios e Convenções) e, em geral, nos preceitos da doutrina contábil.

Portanto, pode-se dizer que 'Fiscalização Contábil' é aquela que se efetua por meio do controle realizado sobre os registros contábeis determinados legalmente, objetivando examinar e verificar a regularidade e a correção técnica da escrituração, a legitimidade dos atos e fatos que deram origem aos lançamentos e a formalização da documentação comprobatória, medindo e avaliando a segurança e a eficiência do sistema de controle interno, próprias do sistema contábil ${ }^{166}$.

\subsubsection{2 - Fiscalização Financeira}

A fiscalização financeira objetiva verificar se as contas públicas representam a efetiva situação financeira da administração, envolvendo controle sobre a arrecadação da receita e a realização da despesa, tendo em conta a legalidade e a regularidade das suas operações.

Constata-se por ela, se foram adotados os meios adequados de se proceder à arrecadação da receita e se foram tomadas medidas apropriadas para registrar com exatidão e salvaguarda, todos os ativos financeiros, como disponibilidades, investimentos e demais valores imobilizados. Também se verificam todos os procedimentos de execução de

\footnotetext{
${ }^{166}$ MILESKI, Helio Saul. O Controle da Gestão Pública. São Paulo: RT. 2003. p.240.
} 
despesa, em especial se foram corretamente autorizadas ou ordenadas e devidamente empenhadas, liquidadas, pagas e registradas.

Permite avaliação da legalidade, legitimidade e economicidade quanto ao aspecto de receitas e despesas estarem sendo arrecadadas e realizadas com observância dos limites financeiros e do período autorizado, com os direitos e as obrigações sendo apurados e geridos de acordo com as normas legais aplicáveis, possibilitando apuração dos erros e fraudes praticados no manuseio dos dinheiros públicos, bem como se as contas traduzem de forma apropriada e fidedigna a situação financeira da administração.

É a fiscalização que indica diretamente a movimentação de recursos financeiros no caixa do Poder Público, isto é, a entrada e saída de dinheiro público em todos os aspectos, seja patrimonial, seja operacional.

Carlos Eduardo Faraco Braga ${ }^{167}$. lembra que importa neste aspecto citar a importância da inserção constitucional da fiscalização financeira no tema de subvenções e renúncias de receita, uma vez que foram duas situações que, no passado, ajudaram no endividamento desregrado e no desequilíbrio financeiro do Brasil.

\subsubsection{3 - Fiscalização Orçamentária}

A partir da mudança de enfoque do antigo orçamento como mero plano financeiro com previsão de receita e fixação da despesa, temos o atual modelo com o orçamento-programa como expressão de um planejamento governamental global, com fixação de metas e objetivos e respectiva identificação dos recursos financeiros.

Assim, a fiscalização orçamentária visa proceder a um acompanhamento de verificação de execução orçamentária propriamente dita, com exame sobre a execução dos programas, projetos e atividades determinados pela lei orçamentária, com observância de fiel cumprimento das normas, procedimentos e dispositivos legais que envolvem todo o ciclo orçamentário, desde a elaboração do Plano de Governo, a Lei de Diretrizes

\footnotetext{
167 Artigo: "A fiscalização financeira e o Tribunal de Contas" acesso em 24/08/2010 www.r2learning.com.br/site/artigos/artigo default.asp?ID=419
} 
Orçamentárias e o Orçamento Anual, incluindo métodos de controle dos créditos orçamentários ou adicionais até o registro dos fatos pela contabilidade.

Possibilita a verificação dos planos de governo no sentido de impedir o desvio de finalidade dos recursos financeiros, evitando que recurso reservado para determinado projeto ou atividade seja aplicado em outra despesa sem autorização da lei de orçamento.

Visa verificar a legalidade dos atos que resultem na arrecadação da receita ou na realização da despesa, conforme disposto na Lei Orçamentária Anual, no sentido de conferir o cumprimento do programa de trabalho expresso em termos monetários e de realização de obras e prestação de serviços. Vale dizer, diz respeito à aplicação do dinheiro público nos exatos termos em que postos no Orçamento.

\subsubsection{4 - Fiscalização Operacional}

A fiscalização operacional serve à avaliação do grau de cumprimento dos objetivos e metas previstos na Lei Orçamentária Anual; à determinação do grau de eficiência (máximo de rendimento, sem desperdícios), eficácia (realização das metas programadas) e economicidade (operação ao menor custo possível) dos atos de gestão praticados.

Também a ela cabe conferir eficiência do controle na administração dos recursos humanos, materiais e financeiros com identificação das áreas críticas na organização e funcionamento da estrutura, visando formulação de sugestões para aprimoramento.

Há avaliação sob a ótica da produção, buscando melhoras na relação custobenefício, identificando causas que provoquem baixo rendimento administrativo, efetuando-se recomendações tendentes à obtenção de melhorias futuras no sistema operativo da administração pública.

Representa, na realidade, evolução conceitual visto que além de pretender preservar as finanças e o patrimônio público também tem sentido de aperfeiçoamento das 
instituições buscando melhor produtividade diante de avaliação de eficiência, eficácia e economicidade.

Aliás, tendo em vista a multiplicidade de conceitos, há referências sobre definições desenvolvidas pela INTOSAI/ONU e aceitas pelo Tribunal de Contas da União, conforme Manual de Avaliação de Desempenho, e se pode extrair:

.Economicidade: minimização dos custos dos recursos utilizados na consecução de uma atividade, sem o comprometimento dos padrões de qualidade;

.Eficiência: relação entre os produtos (bens e serviços) gerados por uma atividade e os custos dos insumos empregados em um determinado período de tempo;

.Eficácia: grau de alcance das metas programadas em um determinado período de tempo, independentemente dos custos implicados;

.Efetividade: relação entre os resultados (impactos observados) e os objetivos (impactos esperados);

.Legalidade: aderência à norma estabelecida, em relação aos atos dos agentes da administração;

.Legitimidade: capacidade do agente de, motivado pelo interesse público, atingir os objetivos da gestão.

\subsubsection{5 - Fiscalização Patrimonial}

Este matiz da fiscalização objetiva manter a preservação dos bens patrimoniais - sejam móveis ou imóveis. Aborda os aspectos da guarda ou responsabilidade pelo uso, ou ainda movimentação, conservação e segurança. Portanto, a expressão patrimônio, neste tópico, está diretamente relacionada com os bens palpáveis, sendo considerada mais específica e menos genérica. 
Cabe mencionar a discussão que será travada no Capítulo 5, quando se abordará a definição de 'patrimônio público', expressão que sob determinados matizes será considerada mais ampla do que simplesmente sinônimo de bens corpóreos móveis ou imóveis, estes objeto de preocupação desta específica modalidade de fiscalização.

Entretanto, para o momento cabe lembrar que os bens imóveis são constituídos pelos bens de uso comum do povo, (de domínio público, como mares, rios, estradas, ruas e praças); bens dominiais (objeto de direito pessoal ou real das entidades) e bens de uso especial (prédios ou terrenos utilizados no serviço ou estabelecimento público, em quaisquer das esferas).

Segundo o Código Civil (art. 98), são públicos os bens do domínio nacional pertencentes às pessoas jurídicas de direito público interno; todos os outros são particulares, seja qual for a pessoa a que pertencerem. E são bens públicos: os de uso comum do povo, tais como rios, mares, estradas, ruas e praças; os de uso especial, tais como edifícios ou terrenos destinados a serviço ou estabelecimento da administração federal, estadual, territorial ou municipal, inclusive os de suas autarquias; os dominicais, que constituem o patrimônio das pessoas jurídicas de direito público, como objeto de direito pessoal, ou real, de cada uma dessas entidades (art. 99) e não dispondo a lei em contrário, também se consideram dominicais os bens pertencentes às pessoas jurídicas de direito público a que se tenha dado estrutura de direito privado.

Também, seguindo as disposições dos artigos 100 a 103, os bens públicos de uso comum do povo e os de uso especial são inalienáveis, enquanto conservarem a sua qualificação, na forma que a lei determinar, enquanto que os bens públicos dominicais podem ser alienados, observadas as exigências da lei; os bens públicos não estão sujeitos a usucapião e o uso comum dos bens públicos pode ser gratuito ou retribuído, conforme for estabelecido legalmente pela entidade a cuja administração pertencerem.

A fiscalização irá verificar, junto aos órgãos fiscalizados, se há procedimento de registro e controle contendo todas as características e a localização de cada bem, e se medidas de conservação, restauração e reparos estão sendo adotadas ou mesmo se está ocorrendo alienação ou transferência de bens imóveis sem o cumprimento 
das exigências legais, lembrando que bens patrimoniais móveis consistem em todo tipo de patrimônio físico controlável e que devido as suas características físicas de duração e valor, devem ser incorporados, mesmo que momentaneamente ao patrimônio da instituição ${ }^{168}$.

Dentro de um contexto mais específico os bens podem ainda ser subdivididos em duas categorias: bens permanentes e bens de consumo.

Os bens permanentes consistem nos bens patrimoniais móveis, que embora ainda tenham uma depreciação rápida, tem uma durabilidade e vida útil maior. Na gestão patrimonial para um bem poder ser considerado permanente, primariamente ele não pode ser peça de reposição de nenhuma espécie e em segundo lugar, deve obrigatoriamente ter uma vida útil contábil (sujeita a avaliação) de dois anos (conforme art. $15 \S 2^{\circ}$ da Lei $n^{\circ}$ 4320/64).

Segundo os conceitos da gestão patrimonial são oficialmente considerados como bens permanentes artefatos do tipo: móveis de escritório, livros, máquinas de manufatura, documentos em geral, computadores e periféricos de informática, veículos, etc.

Os bens de consumo, ao contrário dos bens permanentes, são os bens patrimoniais móveis com vida útil fugaz, isto é, aqueles bens que ou são consumidos prontamente assim que são adquiridos ou então são consumidos em um tempo inferior a dois anos. Como exemplo: material de escritório, peças de reposição para máquinas e equipamentos de informática, produtos de limpeza, gêneros alimentícios e todo e qualquer bem de vida útil efêmera.

Através da fiscalização patrimonial acontece a verificação do inventário para levantamento individualizado e completo dos bens móveis, com conferência de saldos de estoque em almoxarifados e depósitos, além dos equipamentos e materiais de uso permanente nos órgãos fiscalizados.

168 http://www.cpcon.eng.br/gestao-patrimonial/gestao/tipos-de-bens-gestao-patrimonio/ $\quad$ Acesso em 09/04/2012. 
Para que se possa bem efetuar a fiscalização patrimonial importa adotar responsabilidades específicas na gestão dos bens. Neste sentido, levando-se em conta a proposta e o contexto do controle do patrimônio, tal qual no setor privado, o patrimônio pode ser melhor gerido e organizado se levadas em conta rotinas de gestão patrimonial.

Assim, podem ser adotados mecanismos rotineiros, que são práticas encontradas em empresas privadas e que servem de auxílio (não vedado) ao setor público. Vejamo-nas:

Identificação material precisa, quando, por meio de procedimentos padrão da gestão patrimonial tais como identificação através de plaquetas metálicas de códigos de barras ou com nomes e outros dados registráveis há um grande ganho em eficiência e precisão no cadastramento e identificação física do tombamento.

Adequação contábil, onde todo e qualquer órgão pertinente deve estar sempre ciente de qualquer alteração no acervo patrimonial da instituição, observando-se que a comunicação deve ser direta e contínua.

Gestão de Termos de Responsabilidade, quando todo e qualquer termo de responsabilidade relacionado a qualquer tipo de bem patrimonial deve sempre ser encaminhado às unidades gestoras responsáveis.

Registro de transferências físicas para que sempre que houver qualquer transferência física relacionada aos bens patrimoniais móveis da entidade ou unidade do Poder possa ser devidamente registrada, segundo os procedimentos da gestão patrimonial, para que a identificação posterior dos bens fique coesa.

Coordenação e supervisionamento da entrada de bens, visando que a entrada de todo e qualquer novo bem patrimonial móvel no acervo seja prontamente comunicada ao setor de gerência da gestão patrimonial para que o dado bem seja registrado.

Junto ao setor privado, obtém-se, ainda, a definição de controle patrimonial como sendo o gerenciamento de todo o patrimônio de um empreendimento e que abrange desde os ativos tangíveis quanto os intangíveis. 
Pontue-se que este controle é feito também do ponto de vista legal, diante das diversas responsabilidades e normas existentes tanto no âmbito interno como externo do ente a ser fiscalizado.

Quanto aos bens imóveis é preciso mencionar, ainda que de forma breve, que a fiscalização patrimonial deve cuidar, mediante os mecanismos próprios, com os regimes de aquisição, gestão e alienação ${ }^{169}$, para que seja seguido o tratamento legal de cada instituto.

Assim, a fiscalização patrimonial é aquela que diz respeito a alterações ou modificações dos bens patrimoniais cuja titularidade pertence ao Estado ou assemelhado (aqui subentendida a administração pública direta e indireta), com escopo principal de proteção e conservação do patrimônio físico.

Na realidade, há, em diversos momentos, mescla das distintas fiscalizações, ao mesmo tempo em que se interpenetram auxiliando-se mutuamente. Embora distintos os conceitos, atuam sobrepostas, como se pode observar do cruzamento de informações sobre a contabilidade e a fiscalização patrimonial, encontrados nos artigos 94 e seguintes da Lei $\mathrm{n}^{\mathrm{o}} 4.320 / 64$.

Determina a lei que haverá registros analíticos de todos os bens de caráter permanente, com indicação dos elementos necessários para a perfeita caracterização de cada um deles e dos agentes responsáveis pela sua guarda e administração e que a contabilidade manterá registros sintéticos dos bens móveis e imóveis.

Menciona que o levantamento geral dos bens móveis e imóveis terá por base o inventário analítico de cada unidade administrativa e os elementos da escrituração sintética na contabilidade e que para fins orçamentários e determinação dos devedores, terse-á o registro contábil das receitas patrimoniais, fiscalizando-se sua efetivação.

\footnotetext{
${ }^{169} \mathrm{O}$ tema exigiria trabalho à parte visto que necessariamente deveriam ser abordados temas como afetação e atributos dos bens, a forma de adquirir, seu uso, hipóteses de inalienabilidade, impenhorabilidade, imprescritibilidade, os institutos da autorização, permissão, concessão, cessão, comodato, aforamento, locação, arrendamento etc. matéria extensa cujo aprofundamento foge ao escopo do que aqui se discute, porém, com a merecida referência.
} 
Define dívida fundada como sendo os compromissos de exigibilidade superior a doze meses, contraídos para atender a desequilíbrio orçamentário ou a financeiro de obras e serviços públicos (após veto rejeitado, constando no Diário Oficial de 05/05/1964) e indica que deverá ser escriturada com individuação e especificações que permitam verificar, a qualquer momento, a posição dos empréstimos, bem como os respectivos serviços de amortização e juros.

Aponta ainda que os serviços públicos industriais, mesmo que não organizados como empresa pública ou autárquica, manterão contabilidade especial para determinação dos custos, ingressos e resultados, sem prejuízo da escrituração patrimonial e financeira comum e que as alterações da situação líquida patrimonial, que abrangem os resultados da execução orçamentária, bem como as variações independentes dessa execução e as superveniências e insubsistência ativas e passivas, constituirão elementos da conta patrimonial.

Para que a fiscalização patrimonial possa ser bem realizada, é de bom tom que as instituições, seja de forma centralizada, seja por unidades administrativas autônomas, mantenham um órgão interno específico para que a dinâmica do fluxo de informações sobre o patrimônio físico não se perca.

A título de exemplo, recentemente o Ministério Público do Estado de São Paulo criou a "Controladoria Geral do Ministério Público" que se define como: "Órgão da Administração do Ministério Público encarregado de promover a fiscalização contábil, financeira, orçamentária, operacional e patrimonial do Ministério Público por meio da realização de auditorias, inspeções, visitas, exames e outros procedimentos relativos ao controle interno da Instituição".

Visa tal órgão aperfeiçoar os mecanismos de controle interno de modo que sejam observados os princípios constitucionais da Administração Pública, nos termos do art. 74 da Constituição Federal e art. 35 da Constituição Estadual e suas atribuições estão

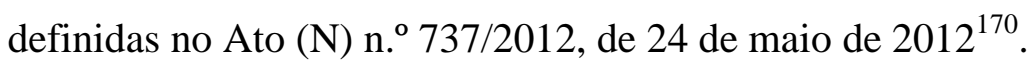

${ }^{170}$ http://www.mp.sp.gov.br/portal/page/portal/Controladoria_Geral. Acesso em 15/08/2012 
O aspecto específico da fiscalização patrimonial deve ser analisado também junto com a discussão sobre o conceito de patrimônio público, visto que não há unanimidade quanto a ele, e sua abordagem mais adiante permitirá o aprofundamento do tema, sendo pelo momento, suficientes as referências realizadas para o escopo do Capítulo.

3.5.3.5.1 - Os procedimentos de Auditoria na Fiscalização Patrimonial ${ }^{171}$

O principal instrumento efetivo de verificação das contas e do gerenciamento do patrimônio público junto à administração pública é a auditoria, realizada enquanto material de trabalho dos Tribunais de Contas.

Assim como no setor privado a auditoria procura atestar a verdade das peças contábeis, verificando se os balanços refletem efetivamente a realidade financeira e econômica das respectivas pessoas jurídicas, no setor público, além do mesmo escopo também tem a função de conferir se houve a sujeição dos programas de governo aos princípios estabelecidos na Constituição Federal (tais como legalidade, legitimidade, economicidade, impessoalidade, moralidade, publicidade e eficiência, alguns deles já estudados no presente trabalho e outros objeto do próximo tópico).

Em realidade, os relatórios das auditorias devem contemplar distintos aspectos da administração pública, razão pela qual devem os auditores deter conhecimentos interdisciplinares, como em Direito Financeiro, Administrativo, Tributário, Contabilidade Pública, Ciência Econômica do Orçamento e técnicas de Administração Pública, permitindo que os dados achados e coletados sirvam de principal referência para as decisões das Cortes de Contas.

Diante de tal finalidade, os relatórios devem ser claros e objetivos, até porque pessoas de distintas áreas, com diferentes enfoques, tem acesso a eles. Assim, tanto os membros da própria fiscalização (Chefes, Diretores, Órgãos de instrução do TC como as Assessorias Técnicas e Secretaria-Diretoria Geral), como dos entes fiscalizados (por exemplo, Prefeitos, Presidentes de Câmaras, quaisquer ordenadores de despesas,

${ }^{171}$ Dados e informações obtidos em visita pessoal realizada junto ao Tribunal de Contas de São Paulo em outubro de 2011. 
Procuradores jurídicos, contadores, tesoureiros, orçamentistas, membros do almoxarifado etc.), Advogados (em eventual defesa em processo), o Conselheiro Relator junto ao Tribunal de Contas, a Comissão de Orçamento e Finanças do Poder Legislativo, os Vereadores e até mesmo membros do Ministério Público e algum interessado da população em geral poderão realizar sua leitura.

Portanto, os relatórios não podem ser confusos, com explicações intermináveis, prolixos e contendo redação repetitiva, sob pena de estarem escondendo a realidade que pretendem mostrar. Não basta a linguagem formal, com termos técnicos, devendo apresentar objetividade com vernáculo compreensível para com todos aqueles que a ele terão acesso.

O processo de auditagem compreende, em regra, três fases: o planejamento, a inspeção local e por último o relatório.

A primeira, do planejamento, costuma acontecer em escritório e tem por início um quadro preliminar da situação orçamentária, financeira, operacional e patrimonial da entidade a ser fiscalizada, com identificação de pontos frágeis sejam formais ou de conteúdo e dos segmentos indicados como principais pontos de interesse que serão fiscalizados. O planejamento permite que os objetivos de campo sejam claros, determinando a extensão e a profundidade da análise que será feita, poupando tempo do auditor (no local dos trabalhos), identificando desde logo os papéis de trabalho a serem utilizados, reduzindo o grau de equívocos e funcionando como instrumento de avaliação dos resultados, quando comparados ao final.

Fornecem amparo ao planejamento a prestação de contas do exercício ${ }^{172}$ que está sendo examinado, os documentos enviados pelo ente ao longo do exercício em respeito às instruções normativas do órgão fiscalizador, as denúncias, representações, os três últimos relatórios da auditoria (sendo observadas anteriores ressalvas e

\footnotetext{
${ }^{172}$ A prestação de contas, no Estado de São Paulo, deve ser remetida ao Tribunal de Contas pelos Municípios até 31 de março do exercício seguinte ao da gestão a ser examinada art. $24, \S 1^{\circ}$ da (Lei Complementar $\mathrm{N}^{\circ}$ 709 , de 14 de janeiro de 1993) devendo ser integrada por diversos documentos que indiquem os programas desenvolvidos, a gestão orçamentária, financeira e patrimonial, além das aplicações no Ensino, na Saúde e os recursos recebidos (Transferências Voluntárias) e concedidos (Repasses ao Terceiro Setor), dentre outros aspectos da gestão dos dinheiros e do patrimônio público.
} 
recomendações) e também as informações dos bancos de dados que ficam à disposição da Auditoria, além de outros (tais como constantes de endereços eletrônicos etc).

Durante o trabalho de planejamento as peças de prestação de contas ensejam a verificação e análise de balanços, de dívida flutuante e fundada, e evolução de dívida ativa além de remuneração dos agentes políticos, permitindo, ainda, a seleção de licitações e dos Restos a Pagar a serem examinados localmente. Também é possível se obervar o universo a ser auditado, mediante a avaliação do nível do controle interno, do resultado do julgamento de contratos, do atendimento às instruções da Corte de Contas, da evolução temporal do déficit de execução orçamentária, do hábito de se realizar corretamente as licitações e os concursos públicos, dentre outros aspectos da gestão financeira e patrimonial.

Não é incomum que se verifiquem defeitos formais com deficiências de origem, insuficiente direção administrativa, falta de treinamento de servidores e desmotivação profissional contribuindo para um andamento nada promissor da gestão financeira e patrimonial da administração pública. Neste sentido os processos de licitação ou mesmo contratações diretas são instruídos inadequadamente, há precário controle de estoques e de material permanente, além de não acompanhamento das concessões de serviços públicos e desatualização dos registros contábeis, dentre outras mazelas administrativas, resultando muitas das vezes em prejuízo ao erário.

É de se recordar que muitas das vezes, um determinado procedimento de auditoria realizado identifica um problema pontual que, porém, se analisado no contexto aponta a existência de problemas em outras áreas. Assim, uma fraude apurada em licitação pode indicar que há necessidade de se verificar Almoxarifado, Tesouraria ou ainda outro setor da administração relacionado com aquela licitação.

Pode-se afirmar, então, que na fiscalização patrimonial da Administração Pública, é certo que problemas encontrados em diferentes setores além dos patrimoniais propriamente ditos, afetam o patrimônio público.

Conforme avaliação do Tribunal de Contas de São Paulo há diversas irregularidades que se tornam as mais comuns encontradas nas auditorias. 
Acontecem em diversas áreas, como no planejamento da gestão pública, por exemplo, negligência na programação do orçamento com elevados níveis de abertura de créditos adicionais ou lei orçamentária anual que não prevê superávit orçamentário para amortizar estoque descoberto de Restos a Pagar ou ainda ausência de audiências públicas para discutir o Plano plurianual, a Lei de Diretrizes Orçamentárias ou a Lei de Orçamento Anual, nos termos do art. 48 da Lei de Responsabilidade Fiscal.

Há problemas na gestão das receitas (renúncia irregular de receitas, sem observância dos rigores do art. 14 da LRF), na dívida ativa (prescrição ou decadência de créditos), em multas de trânsito (aplicação em despesas não previstas no art. 320 do Código de Trânsito Brasileiro), no setor da Educação (inclusão de gastos com cultura, esportes, eventos cívicos e assistência social), da Saúde (inclusão de servidores que não militam de fato, na área), nos Precatórios Judiciais (não pagamento de valores correspondente aos precatórios judiciais), em subsídios de agentes políticos (fixação de remuneração depois do pleito eleitoral), na execução orçamentária (déficit orçamentário mesmo depois da emissão de alertas pela Corte de Contas), em transferências ao terceiro setor (entidade beneficiária que não elabora plano de trabalho), licitações (editais com cláusulas que afastam concorrentes, repetição de convites ou convites preenchidos por empresas inexistentes, fracionamento etc), em pessoal (contratação temporária sem processo seletivo), tesouraria (pagamento sem prévio empenho) e outros.

Com relação aos bens fisicamente considerados são observadas execuções contratuais com problemas referentes a obras não explicitadas no Cadastro Eletrônico de Obras; falta de medição nos trabalhos de rua e de livro ponto para as turmas de rua; ausência de responsável para acompanhamento de serviços terceirizados e de relatórios consistentes de atividades em serviços delegados ao particular, além da falta de atestados de recebimento de obras (provisório ou definitivo) e de cronogramas de trabalho. Também os almoxarifados apresentam problemas com falta de inventários periódicos, de segurança na estocagem, de definição dos níveis de estoque, de emissão de requisições de saída de material de falta de conferência de validade dos produtos estocados.

Junto ao Patrimônio os maiores questionamentos acontecem com relação à falta de inventário físico periódico, inexistência de termos de transferência, falta de 
averbação no Registro de Imóveis de novas construções e ou ampliações, inexistência de plaquetas de identificação nos móveis, ausência de ata de transmissão e recebimento do patrimônio quando da troca de mandato do Chefe do Poder Executivo e ainda não efetuação de cobertura mediante seguros.

Uma vez feito o planejamento a fase seguinte é de campo, propriamente dita e acontece com procedimentos internos e externos por parte dos auditores. Cada elemento da fiscalização (como, por exemplo, receitas, despesas, multas de trânsito, aplicação no Ensino e Saúde, pagamento de precatórios judiciais etc) tem procedimentos próprios e pertinentes com as peculiaridades de cada um. Diante do tema patrimonial tratado, serão mencionados alguns mais afetos a ele.

Assim, é verificada a Contribuição de Intervenção no Domínio Econômico (CIDE) que deve ser empregada tão somente nos programas de infraestrutura de transportes e com objetivo de reduzir o consumo de combustíveis automotivos, o atendimento mais econômico da demanda de transportes de pessoas e bens, além de segurança e conforto de usuários e diminuição do tempo de percurso e menor participação de fretes e dos custos portuários na composição final dos preços de produtos de consumo interno e de exportação.

O auditor, já de posse do demonstrativo de receitas e despesas (encaminhado pelo ente), deve comparar os valores do Balancete das Receitas ou do Comparativo da Receita Orçada com a Arrecadada com o das transferências constitucionais feitas pela União (acessível no sítio eletrônico da Fazenda) e em procedimento externo verificar o saldo bancário no início e no fim do exercício, em conta corrente vinculada, mantida em agência local (ou mais próxima) do Banco do Brasil, conferindo-o com o saldo do Boletim de Caixa a ser aplicado no exercício seguinte. Também observar rendimentos de aplicações financeiras das receitas $\operatorname{CIDE}^{173}$ e se as

\footnotetext{
${ }^{173}$ A Lei no 10.336 , de 19 de dezembro de 2001, instituiu a Cide-Combustíveis, Contribuição de Intervenção no Domínio Econômico incidente sobre a importação e a comercialização de gasolina e suas correntes, diesel e suas correntes, querosene de aviação e outros querosenes, óleos combustíveis (fuel-oil), gás liquefeito de petróleo (GLP), inclusive o derivado de gás natural e de nafta, e álcool etílico combustível. A CIDECombustíveis tem como fatos geradores as operações, realizadas com os combustíveis elencados no art. $3^{\circ}$ da Lei $\mathrm{n}^{\circ}$ 10.336, de 2001 (gasolinas, diesel, querosenes, etc.) quando de comercialização no mercado interno e em importação. São contribuintes da Cide-Combustíveis, o produtor, o formulador e o importador (pessoa física ou jurídica) dos combustíveis elencados no art. $3^{\circ}$ da Lei n ${ }^{\circ} 10.336$, de 2001.
} 
despesas indicadas no demonstrativo são condizentes com programas de infraestrutura de transportes, além de confrontar as despesas previstas e aplicadas por projeto/atividade, indicadas nos registros contáveis e gerenciais com as Notas de Empenho e respectivos comprovantes fiscais. No Plano Plurianual e na LDO, nos municípios, deve existir programa intitulado "Programa de Infraestrutura de Transportes Custeados com Recursos CIDE".

Quando da verificação de licitações, o auditor, deve preencher quadro indicativo da modalidade (concorrência, tomada de preços, convite, leilão, concurso, pregão) apontando quantas foram realizadas e quantas vieram a ser examinadas. Também verificar quantas e quais foram as dispensas e as situações de inexigibilidade. Em seguida, selecionar quais serão objeto de exame in loco, podendo priorizar os de maior valor, aqueles referentes a Ensino e Saúde, os que tenham denúncias ou representações e os que indiquem algum impacto patrimonial significativo. Também podem chamar atenção se muitos forem os certames com o mesmo objeto, posto que indicativos de possível fracionamento ou modalidade inadequada, e devem ser observadas aquisições de bens de fornecedores contumazes (repetições de convites, por exemplo).

Diversos podem ser os procedimentos internos da auditoria para verificação de licitações. Podem ser indicados: exame de formalização de aquisições pré-selecionadas; observância de que a competitividade foi garantida e que o Edital não constou com cláusulas restritivas ou impeditivas; constatação da liquidação das despesas específicas que se originaram de licitação (ou de sua dispensa ou inexigibilidade); verificação de que os participantes estavam legalmente constituídos e de que suas atividades, de fato, se relacionavam com o objeto da licitação (inclusive se constatando se a empresa não foi constituída em vésperas de novo mandato e se está registrada na Junta Comercial e no Cadastro Nacional de Pessoa Jurídica). Também deve se pesquisar se o contratado é parente de agentes políticos ou servidores e se existem aquisições sistemáticas. Para testes do almoxarifado e do patrimônio devem ser selecionadas aquisições de materiais de consumo e de caráter permanente.

Quando da seleção amostral da pesquisa, os auditores, podem ter em consideração alguns parâmetros, quais sejam: alguns produtos e serviços são de mercado altamente competitivo, então as empresas costumam ter profissionais especializados para 
as licitações visando exame detido da documentação das concorrentes, conseguindo obter em recurso a desclassificação delas, o que indica prévia análise pelos concorrentes dos documentos apresentados, auxiliando, assim, o auditor que pode se valer das informações obtidas. Para bens com baixa variação de preço (automóveis e combustíveis) dificilmente os processos licitatórios apresentam falhas quanto à economicidade; obras com preços iniciais bem abaixo das demais propostas tendem a ser aditadas, quando da execução do contrato, até o máximo do limite legal (em especial quando de serviços de vulto como coleta de lixo e publicidade).

Os contratos também costumam impactar no tema do patrimônio, assim, é de se mencionar procedimentos.

Para aqueles remetidos ao Tribunal, os auditores devem apurar se os entes vêm cumprindo as Instruções da Corte com relação à remessa dos contratos ou seus termos aditivos, modificativos ou complementares (conforme inciso II, letra "c" do art. 23 da Lei Federal $n^{\circ} 8.666 / 93$ e alterações) além de verificar no sistema de protocolo se foram remetidos contratos no exercício em exame mencionando-se, de modo expresso, no relatório o não envio daqueles superiores ao limite de remessa.

$\mathrm{Na}$ atuação externa, em especial verificar quando dos analíticos da despesa os empenhos de valor superior ao limite de remessa. Solicitar, ainda, no Setor de Compras a relação de licitações de exercícios anteriores para confrontação com o do exercício em exame, anotando se os aditivos atuais, somados aos contratos de anos anteriores não ultrapassam a barreira do mencionado artigo 23 da Lei de Licitações.

Quando da análise in loco de contratos, internamente devem ser selecionados, na relação dos contratos e atos jurídicos análogos aqueles que serão objeto da verificação na própria origem, devendo se incluir aqueles firmados com "organizações sociais qualificadas" e os do "cadastro eletrônico de obras em execução", enquanto que externamente além de examinar a formalização dos processos pré-selecionados constatar como está sendo a sua execução e se está compatível com o termo de ajuste, incluindo a vistoria de obras e se estão sendo atendidos os artigos 16 e 45 da Lei de Responsabilidade Fiscal (estimativa de impacto financeiro-orçamentário, previsão no PPA e na LDO e não paralisação de outros projetos). 
Nas execuções contratuais verificar a entrega do objeto no prazo, na quantidade e qualidade pactuadas constatando-se a correção do pagamento quanto a prazo e valor. Observar os acréscimos e supressões, repactuação de valores sob argumento de reequilíbrio financeiro, prorrogação de prazos e se estão devidamente documentados, além de se mostrarem efetivamente necessários. Quando da vistoria de obras observar sua real existência, se foram utilizados materiais descritos no projeto executivo, se a obra está respeitando o cronograma físico-financeiro, procedendo-se ao exame da entrega de materiais mediante registros do Almoxarifado e Patrimônio (fichas de entrada e saída de bens de consumo e de caráter permanente). Contatar se há obras paralisadas (em afronta ao art. 45 da LRF).

No Almoxarifado (que responde pelas funções de recebimento, armazenamento de distribuição dos materiais) não há mais o problema de outrora do excesso de estoques, visto que o equilíbrio da moeda, sem alta de inflação faz com que os materiais possam ser comprados a qualquer tempo e as técnicas modernas de logística não recomendam grandes estoques. Assim, os auditores devem comparar os valores constantes do Balanço Patrimonial com o Balancete do Almoxarifado e com o inventário do Estoque de Dezembro; somar os valores gastos com material de consumo e conferir com as entradas no Almoxarifado; apurar quantos Almoxarifados existem (central, medicamentos, merenda escolar etc.); qual a relação entre os distintos Almoxarifados no que tange ao recebimento, conferência, controle de entrada e saída e elaboração de balancetes mensais apurando se os controles se complementam ou são truncados; apurar se o material foi destinado efetivamente para o setor para o qual foi comprado; se foram feitos os balancetes mensais e enviados ao setor contábil; se os balancetes discriminam valores e materiais; selecionar bens do estoque e comparar a quantidade real com aquela lançada no sistema de controle; examinar em dias aleatórios os registros de entrada por meio das notas fiscais de entrada, de empenho, fichas de controle ou outro sistema similar e da mesma forma os registro de saídas valendo-se das requisições de materiais e recibos de entrega. Conferir ainda os controles de entrega de combustíveis e de consumo, em especial em entes que têm bombas próprias.

O controle central, se não existir, deve ser recomendado pelos Auditores aos entes fiscalizados, visto que quando o Almoxarifado Central é informado do estoque 
mensal dos bens de consumo e registra sua movimentação é possível se apurar o consumo médio mensal dos materiais, inibindo-se desperdícios nos setores usuários, vez que estes costumam efetuar controles físicos precários.

Para os bens patrimoniais, a Auditoria deve conhecer e examinar os registros mantidos pelo ente (se informatizados ou manuais) escolhendo para teste físico os de maior valor monetário; selecionar, na análise da documentação da despesa, as aquisições de materiais permanentes verificando se os bens foram registrados, se estão identificados, apurando se a localização deles coincide com aquela constante dos registros; verificar se todos os bens móveis e imóveis estão registrados analiticamente no setor responsável (conforme art. 94, da Lei Federal n 4.320/64) e sinteticamente no setor contábil (art. 95 da mesma Lei). Verificar se são mantidos termos de responsabilidade pelos bens, separados por setores da Administração, cabendo ao chefe ou a outro funcionário designado sua guarda (art. 94); verificar por amostragem as baixas ocorridas no exercício, se foi aberto processo administrativo para sua formalização, se houve autorização para a baixa por autoridade superior e se o responsável pelo bem foi arrolado em tal processo. Quando de reavaliação de bens móveis e imóveis (art. 106 da Lei Federal $\mathrm{n}^{\text {o } 4.320 / 64)}$ verificar nomeação de comissão, critérios utilizados e laudos e se a reavaliação registrada contabilmente também consta nos registros.

A Auditoria não acontece apenas na administração direta, mas também na indireta e cita-se como exemplo que a fiscalização deve anotar no item "atividades desenvolvidas" um breve resumo das atividades e projetos desenvolvidos por autarquias e fundações de direito público, não somente quanto a obras e novos serviços, mas também no que tange à operação dos pré-existentes (tal como: 'autarquia de água e esgoto' construção de nova estação de tratamento de água e abastecimento de 1600 residências). As entidades devem apresentar resultado efetivo bem como indicar que suas atividades guardam compatibilidade com suas finalidades institucionais, incumbindo à Auditoria assim conferir.

Finalmente, é de se recordar que o Patrimônio Público (como aqui considerado) não é 'zerado' a cada exercício. É entendido como um conjunto de bens, direitos e obrigações que evolui no tempo, ainda que em decorrência de execução orçamentária, mas que também tem característica de continuidade. Assim, enquanto a 
execução do orçamento é delimitada no tempo, a evolução financeira e a patrimonial são continuadas, o que justifica que sob o aspecto contábil seja adotado um controle separado para os sistemas orçamentário, financeiro e patrimonial. O patrimônio pode ser alterado independentemente da execução orçamentária, por exemplo, quando se inscreve a Dívida Ativa cria-se um direito que não decorreu de arrecadação ou de despesa orçamentária, mas o patrimônio é afetado pelo crescimento dos créditos.

Portanto, existe a necessidade de que a Auditoria verifique se os registros contábeis estão adequados para que se possa, em outro momento se realizar a análise pela contabilidade que irá permitir a interpretação por distintos setores e órgãos fiscalizadores, assim como também verifique o respeito às diretrizes que disciplinam o orçamento, com o mesmo escopo, na medida em que, por exemplo, uma despesa orçamentária na categoria econômica implica em verificação de manutenção e custeio da máquina pública (despesa corrente) e de aumento do patrimônio público líquido do setor público, como obras, equipamentos, amortização da dívida (despesa de capital). Já uma alteração na conta "Mutações Patrimoniais" indica operação orçamentária envolvendo a troca, modificação e mudança de bens, direitos e obrigações, de modo comum referidas por permuta de dinheiro por bens de caráter permanente como bens móveis, imóveis, títulos e valores (uma despesa com aquisição de veículo engrandece o ativo patrimonial).

Portanto, há diretrizes para os procedimentos diante do Balanço Patrimonial e das Variações Patrimoniais. Os auditores devem, então, verificar no Livro Diário se consta o Balanço Patrimonial e confrontá-lo com aquele enviado na prestação de contas; verificar e há registros analíticos de todos os bens de caráter permanente e se há registros sintéticos dos bens moveis e imóveis; se há inventário geral dos bens móveis e imóveis identificados por unidades administrativas e condizentes com os registros sintéticos contábeis e no caso da existência de estoques, constatar se houve inventário físico e financeiro ao final do exercício. É comum que os valores registrados nas Variações Patrimoniais Ativas e Passivas relativas ao Almoxarifado sejam idênticas, isto é, há registro de entradas e saídas concomitantes, desconsiderando possíveis estoques nas diversas unidades administrativas. Devem, então, ser apontadas, quando dos relatórios, as faltas de controle interno e a incorreta evidenciação (art. 83 da Lei $\mathrm{n}^{\circ}$ 4.320/64). 
Quando das variações patrimoniais ativas, devem ser confrontados os valores constantes nas Variações Ativas Resultantes da Execução Orçamentária com o total da Receita Arrecadada do Balanço Orçamentário, atentando os auditores para os valores idênticos nas Variações Patrimoniais Ativas - Mutações Patrimoniais, relativos ao Almoxarifado (entradas) e nas Variações Patrimoniais Passivas - independentes de Execução Orçamentária (saídas), pois indica que o ente não considera os eventuais estoques ao final do exercício nos diversos setores da Administração.

Se nas Variações Patrimoniais Passivas houver valores maiores do que aqueles relacionados às receitas de alienações (resultante da Execução Orçamentária), podem corresponder a baixa de bens inservíveis, após avaliação de comissão própria, ou seja, não compondo mais o patrimônio, mas não submetidos à venda ou doação. Devem os auditores confrontar os valores constantes nas Variações Patrimoniais Passivas Resultantes da Execução Orçamentária com o total da Despesa Empenhada no Balanço Orçamentário. Também verificar nas Variações Patrimoniais Passivas, independente da Execução Orçamentária, se não houve cancelamento de créditos inscritos da Dívida Ativa e em caso positivo solicitar à origem os motivos, pois além de contribuir para a diminuição do Patrimônio potencialmente estará afetada a arrecadação.

Quando das Variações Patrimoniais deve ser verificado nos setores competentes as guias de receitas, o registro patrimonial dos bens e das respectivas baixas; se houve processo administrativo para reavaliação dos bens alienados e as qualificações dos membros avaliadores, sendo que em caso de baixa de bens inservíveis, os auditores devem solicitar a respectiva relação, constatando se houve processo administrativo, comissão nomeada para avaliação, qualificação dos membros e previsão quanto à destinação dos bens (alienação, doação). Observar, ainda, a relação de veículos inservíveis e fazer testes com demonstrativos de abastecimentos, posto que podem ser utilizadas placas daqueles que não mais circulam, em especial nos casos das áreas de Saúde e Educação diante da exigência do atendimento aos mínimos constitucionais de aplicação.

Existem fatores que influenciam os resultados econômico e patrimonial de modo positivo ou negativo e devem ser objeto de observância, posto que alguns derivados de atuação irregular do ente e outros a serem recomendados como prática de boa administração. 
Assim, a título de exemplo, o Cancelamento de Restos a Pagar Liquidados, de precatórios empenhados e posteriormente cancelados diminuem a dívida de curto prazo (Passivo Financeiro), desonerando as disponibilidades (Ativo Financeiro), entretanto as operações são irregulares, contribuindo de forma fictícia para o resultado positivo ou abrandando o negativo.

O deslocamento de Restos a Pagar, incluindo precatórios, indevidamente cancelados ou transportados para a Dívida Fundada, que requer também amortização, mas não a curto prazo, indica que deve o auditor atentar em especial para os oito meses finais de mandato conforme art. 42 da LRF, sendo irregular a operação.

O aumento do saldo dos valores inscritos em Dívida Ativa, se por um lado é fator positivo por outro é indício de problemas no sistema de instituição e arrecadação de tributos ou na inércia na recuperação dos créditos, contrariando também a LRF.

Já o aumento do Ativo Permanente por aquisição de bens móveis e imóveis ou acréscimo de valores e a chamada "Consolidação" que é a encampação de resultados positivos de entes da Administração Indireta também devem ser referidos como fatores que influenciam o resultado patrimonial de modo positivo.

Entretanto, influencia de modo negativo o resultado patrimonial a Execução Orçamentária deficitária por má gestão (receitas menores que as despesas), pois além de constituir novas dívidas de curto prazo (Restos a Pagar) pode ainda amortizar estoque existente, sendo que podem ocorrem déficit de execução por motivos positivos tais como investimentos. Influencia, ainda, de modo negativo a dilapidação do Patrimônio Público a ausência de avaliação de elementos patrimoniais (nos termos no art. 106 da Lei ${ }^{\circ}$ 4.320/64) visto que no caso de bens móveis e imóveis o ato é facultativo ( $\$ 3^{\circ}$ do mesmo artigo) e a diminuição do Ativo Permanente por perda de bens móveis e imóveis decorrentes de acidentes ou incêndios, caracterizando uma insubsistência ativa, ou seja, fator inesperado que ocorre diminuindo o ativo patrimonial e, finalmente, a “Consolidação" quando o resultado de entes da Administração Indireta for negativo. 
Realizada a segunda etapa do trabalho (a de pesquisa propriamente dita), a Auditoria deve elaborar relatório que será analisado oportunamente quando do julgamento das Contas pelo Tribunal em conjunto com as demais informações obtidas.

Evidentemente diversas outras são as ações que os auditores devem empreender no sentido de auxiliar e complementar a atuação dos Tribunais de Contas, sendo as aqui referidas somente um pincelar das atribuições diante do tema patrimonial.

3.6 - O artigo 70 da Constituição Federal.

Passa-se ao estudo dos elementos jurídicos trazidos pelo art. 70 da Constituição Federal, isto porque os tipos de fiscalização acima estudados e que servem de medida para o controle externo a ser exercido pelo Poder Legislativo e também pelo controle interno de cada ente, devem levar em conta as diretrizes apresentadas pela Carta Magna, vale dizer, a fiscalização em seus distintos matizes acontece quanto à legalidade, legitimidade, economicidade, aplicação de subvenções e renúncia de receitas.

Importa transcrever o que diz o artigo:

Art. 70. A fiscalização contábil, financeira, orçamentária, operacional e patrimonial da União e das entidades da administração direta e indireta, quanto à legalidade, legitimidade, economicidade, aplicação das subvenções e renúncia de receitas, será exercida pelo Congresso Nacional, mediante controle externo, e pelo sistema de controle interno de cada Poder.

Já se afirmou que a ação estatal deve se desenvolver em favor do interesse coletivo e que a sociedade deve exercer sobre ela efetivo controle nas distintas áreas de atuação, em especial no setor financeiro e patrimonial. Na medida em que tal controle foi alçado à categoria constitucional, deve ser obedecido o referencial adotado pelo legislador maior para que venha a ser efetuado. 
Assim, passa-se ao estudo dos institutos da legalidade ${ }^{174}$, da legitimidade, da economicidade, e ainda da aplicação de subvenções e renúncia de receitas.

\subsection{1 - Legalidade}

De fato, o princípio da legalidade é aquele que dá eficácia a toda atividade administrativa, e, portanto, à atividade financeira e patrimonial do Estado. É ele quem indica que há necessidade absoluta de que a administração pública se submeta ao ordenamento jurídico existente.

Resulta que a administração pública deverá realizar o plano de governo traçado no orçamento submetendo-se ao controle de todos os órgãos fiscalizadores, que, por sua feita irão avaliar juridicamente a regularidade dos atos praticados, verificando eventual desvio de poder ou interesse pessoal do administrador que age em detrimento do interesse coletivo.

Consectária da legalidade é a probidade, e em sucessão, a lealdade. Significa que as ações dos administradores públicos devem respeitar o aparato jurídico calcados na honestidade e no dever de respeito às normas traçadas para o exercício de sua atividade sendo também adequado relembrar a questão já abordada acerca da lei de improbidade administrativa e suas respectivas sanções, como parâmetro da atividade do agente público, respaldada pelo princípio da legalidade.

Em função da amplitude da análise jurídica quanto à legalidade, a fiscalização contábil, financeira, patrimonial e orçamentária pode ser, sob certo matiz, exercida por meio do controle de constitucionalidade das leis e dos atos administrativos e na medida em que os textos legais impactam no patrimônio público, e, por consequência em sua fiscalização, importa verificar seu funcionamento.

\footnotetext{
${ }^{174}$ A legalidade já foi objeto de estudo no item 2.1.2.1, porém deve ser renovada a referência neste momento, diante da adequação com o tema aqui tratado, ampliando-se, assim, sua abordagem.
} 
3.6.1.1 - Controle de Constitucionalidade.

Cabe aqui breve abordagem sobre o controle de constitucionalidade das normas, e no tema, a doutrina refere o controle abstrato e o concreto e ainda de maneira concentrada ou difusa.

O controle de constitucionalidade é disciplina instrumental, operacional do Direito, e todas as normas do sistema jurídico são passíveis do crivo por tal controle ${ }^{175}$. Está ligado à ideia de supremacia da Constituição sobre todo o ordenamento jurídico, à rigidez constitucional e à proteção dos direitos fundamentais ${ }^{176}$.

Significa verificar a adequação ou compatibilidade de uma lei ou ato normativo com a constituição, verificando tanto requisitos formais, como materiais, sendo formais subjetivos aqueles pertinentes à fase introdutória do processo legislativo (iniciativa para propor leis) e formais objetivos aqueles referentes às fases constitutiva e complementar do processo legislativo (arts. 60 a 69 da CF). Já os materiais ou substanciais dizem respeito à verificação material da compatibilidade do objeto da lei ou do ato normativo com a Constituição Federal.

O controle pode ser preventivo, quando se pretende impedir que alguma norma ingresse no ordenamento jurídico (já que está maculada pela inconstitucionalidade), sendo que via de regra acontece no Poder Legislativo (comissões de constituição e justiça) ou no Poder Executivo (veto) ou pode ser repressivo, quando se busca eliminar norma já editada em desrespeito à constituição, acontecendo tradicionalmente junto ao Poder Judiciário.

Este último pode acontecer, em regra, por dois sistemas, a saber: reservado ou concentrado (via de ação) e difuso ou aberto (via de exceção ou defesa), sendo que a Constituição Federal no art. 49, V prevê hipótese em que o próprio Poder Legislativo pode sustar atos normativos do Poder Executivo que exorbitem seu poder regulamentar ou a

\footnotetext{
${ }^{175}$ FAJARDO, Cláudio Marcelo Spalla. Súmula STF no 346: Uma nova abordagem sobre a competência do TCU para apreciar a constitucionalidade de leis e de atos normativos do Poder Público. Revista do TCU. Ano 40. No 111 - Janeiro/Abril 2008, p.18

${ }^{176}$ MORAES, Alexandre. Direito Constitucional São Paulo: Atlas, 1999, p.524
} 
delegação legislativa por meio de decretos legislativos do Congresso Nacional sustando o decreto presidencial (art. 84, IV da CF) ou a lei delegada (art. 68 da CF).

O controle concentrado permite que a declaração de inconstitucionalidade da lei ou ato normativo seja obtida independentemente da existência de um caso concreto, e no Brasil pode acontecer pela ação direta de inconstitucionalidade genérica (art. 102, I, a da $\mathrm{CF}$ ), ação direta de inconstitucionalidade interventiva (art. 36, III), ação direta de inconstitucionalidade por omissão (art. 103, $\$ 2^{\circ}$ ) e ação declaratória de inconstitucionalidade (art. 102, I, a, in fine, $\mathrm{EC} \mathrm{n}^{\circ}$ 03/93).

O controle difuso se caracteriza pela permissão de todo e qualquer juiz ou tribunal realizar no caso concreto a análise sobre a compatibilidade do ordenamento jurídico com a Constituição Federal ${ }^{177}$. Outorga-se ao interessado a declaração de inconstitucionalidade somente para efeito de isentá-lo, no caso concreto, do cumprimento da lei ou ato produzidos em desacordo com a Lei maior, permanecendo válido aquele comando normativo em relação a terceiros.

Na realidade, a declaração de inconstitucionalidade é necessária para que o interessado obtenha no caso concreto sua pretensão, sendo declarada de forma incidental, não se constituindo no objeto principal da ação.

Pode se valer o interessado da via do habeas corpus, do mandado de segurança ou de ações ordinárias, entretanto para a ação civil pública encontram-se óbices.

$\mathrm{Na}$ medida em que a principal característica da modalidade de controle de constitucionalidade difuso é o fato de ser exercitável somente para o caso concreto, uma ação proposta com natureza coletiva e que gere efeito erga omnes estará usurpando competência do Supremo Tribunal Federal.

Assim, já decidiu o STF na Reclamação $n^{\circ} 601$ de relatoria do Ministro Carlos Veloso acerca da impossibilidade do uso da ação civil pública para exercer controle concentrado de constitucionalidade de lei ou ato normativo, vindo assim a substituir ação direta de inconstitucionalidade ${ }^{178}$.

\footnotetext{
${ }^{177}$ MORAES, Alexandre. Direito Constitucional São Paulo: Atlas, 1999, p.531

${ }^{178}$ STF. Reclamação no 601. Rel. Min. Carlos Veloso, in Revista de Direito Administrativo 206/267
} 
Entretanto, se a ação civil pública tiver por escopo a defesa de direitos individuais homogêneos, (art. 81, III da Lei $n^{\circ}$ 8.078/90) a decisão somente alcançará um universo determinado de pessoas, sendo, então, permitido o controle de constitucionalidade ${ }^{179}$.

Assim, vê-se que o Ministério Público, na qualidade de legitimado para o polo ativo da ação civil pública, poderá provocar o Poder Judiciário para exercer tal controle.

Logo, a retirada de determinada norma do mundo jurídico, se reconhecida sua inconstitucionalidade, é de competência exclusiva do Poder Judiciário (art. 102, I, a; art. 103 e parágrafo e art. 129, IV da CF), entretanto fala-se da possibilidade de que o controle de constitucionalidade seja feito de forma extrajudicial, resultando em negação de eficácia e executoriedade ao ato examinado e assim declarado.

Abre-se polêmica a respeito da possibilidade dos Tribunais de Contas exercerem tal controle e vale abordar a discussão, na medida em que aqueles Tribunais são essenciais para a fiscalização patrimonial da administração pública.

3.6.1.1.1 - Controle de Constitucionalidade e o Tribunal de Contas.

Observa-se da Súmula 347 do STF: “O Tribunal de Contas, no exercício de suas atribuições, pode apreciar a constitucionalidade das leis e dos atos do poder público".

O tema, apesar da Súmula, não é pacífico e há resistências do próprio Poder Judiciário, como se pode observar de decisões do Supremo Tribunal Federal em diversos mandados de segurança ${ }^{180}$.

${ }^{179}$ STF. Reclamação n ${ }^{\circ}$ 554-2/MG. Rel. Min. Mauricio Correa. Diário da Justiça, seção I, 26.11.97, p. 61.738.

${ }_{180}^{\text {,STF, MS nos }}$ 27743; 26.410; 25.986; 27.232; 25.888; 27232 26410; 25888; 27796; e 27837. 
É de se lembrar que a referida Súmula foi editada em dezembro de 1963, e muito se alterou desde então no universo jurídico. À época, três foram as premissas que o STF tomou como supedâneo para a edição da Súmula $347^{181}$.

Pela primeira, considerava-se que todos tinham competência para deixar de aplicar norma inconstitucional. Assim, é possível se perceber um conflito com o tema da presunção de constitucionalidade das normas (relativa, diante do controle prévio), e também com a necessidade dos Tribunais de Contas que decorre da competência constitucional, realizada mediante procedimento especial e não de forma aleatória.

Pela segunda, haveria uma distinção entre afastar a aplicação das leis e declarar sua inconstitucionalidade. Na prática inexiste diferença ontológica e se verifica que um magistrado de primeira instância decide incidentalmente pela inconstitucionalidade da norma para decidir pela sua não aplicação.

A terceira premissa indicava que leis ou atos inconstitucionais por serem inexistentes não surtem efeitos. Carregada de formalismo, tal visão desconsiderava a necessidade do direito se adequar à realidade que o cerca. Cita-se como exemplo o sujeito que teve seu direito amparado por muitos anos e ao cabo de uma decisão judicial tida por meramente declaratória (e não constitutiva) percebe que seu direito nunca existiu, porque a lei que o amparava apresentava vício de iniciativa. Refere-se neste tema a 'teoria da aparência' no dizer de Florivaldo Dutra de Araújo 182 “a expressão de maior intensidade da teoria da aparência é a que faz geradora de direitos subjetivos uma situação fática em contrariedade com o ordenamento jurídico".

Observando-se a Lei n 9868/1999 que trata da apresentação de Ação Direta de Inconstitucionalidade perante o STF, há previsão (art. 27) de ao declarar a inconstitucionalidade de lei ou ato normativo pela maioria de dois terços dos membros, restringir-se o efeito da declaração ou decidir que tenha eficácia somente a partir de seu trânsito em julgado, e isto por razões de segurança jurídica ou interesse social.

181 FAJARDO, Cláudio Marcelo Spalla. Ob cit: Súmula STF no 346: Uma nova abordagem sobre a competência do TCU para apreciar a constitucionalidade de leis e de atos normativos do Poder Público. Revista do TCU. Ano 40. No 111 - Janeiro/Abril 2008, p.28

182 ARAÚJO, Florivaldo Dutra de. Motivação e controle do ato administrativo. Belo Horizonte: Del Rey, 1992, p.55 
Desta forma, as premissas que embasaram a edição da Súmula 347 não parecem mais atuais com relação ao pensamento jurídico, em que pese a competência para apreciação da constitucionalidade de leis em casos concretos ter inteira validade, tanto para juízes como para tribunais do Poder Judiciário e para os Tribunais de Contas.

Pode-se, entretanto, afirmar que existe a necessidade da Corte de Contas usar da prerrogativa de exercer o controle de constitucionalidade como instrumento essencial ao controle externo, que a ela incumbe. A apreciação da inconstitucionalidade passa a ser, então, de caráter incidental.

Assim, se o Tribunal de Contas se depara com uma norma que supostamente autorizaria algum órgão de sua jurisdição ao cometimento de ilícito, não teria outra solução que não afastar a aplicação da norma, de modo que não viesse a afetar ainda mais o patrimônio e a moralidade pública.

Ao apreciar uma questão que lhe cabe decidir e identificando conflito entre a norma ou o ato normativo e a Constituição, deverá resolver a questão prejudicial de inconstitucionalidade preliminarmente ao julgamento do mérito do caso concreto, caracterizando assim, o controle difuso da constitucionalidade ${ }^{183}$.

Pode-se estabelecer um paralelo com a afirmação de que a competência de apreciar a constitucionalidade de leis, nos casos concretos, pelos juízes do Poder Judiciário não decorre de expressa previsão constitucional, mas sim da natureza de sua função.

$\mathrm{O}$ art. 97 da Constituição Federal ${ }^{184}$ refere-se à reserva de plenário (o que também se encontra no art. $89, \S 2^{\circ}$, b da Lei Complementar $n^{\circ} 35^{185}$ - LOMAN) e não se encontra dispositivo outro que refira a competência de controle de constitucionalidade aos juízes singulares.

\footnotetext{
${ }^{183}$ SODRÉ, Mariana Priscila Maculan. Controle de Constitucionalidade pelo Tribunal de Contas da União. In SOUZA JÚNIOR, José Geraldo de. (org). Sociedade democrática, direito público e controle externo. Brasilia: Tribunal de Contas da União, 2006, p.129/142.

${ }^{184}$ Art. 97. Somente pelo voto da maioria absoluta de seus membros ou dos membros do respectivo órgão especial poderão os tribunais declarar a inconstitucionalidade de lei ou ato normativo do Poder Público ${ }^{185} \S 2^{\circ}$ - Compete, ainda, ao Tribunal Pleno: a) uniformizar a jurisprudência em caso de divergência na interpretação do direito entre as Seções; b) declarar a inconstitucionalidade de lei ou ato normativo;
} 
Assim, então, a competência do Tribunal de Contas para o controle de constitucionalidade decorre não de autorização constitucional, mas da natureza de sua função constitucional.

Entretanto, à primeira vista, parece que poderia o Tribunal de Contas exercer tal controle na modalidade difusa somente, porém é de se dizer que o Tribunal de Contas da União possui atribuições que podem ensejar a possibilidade de 'dizer o direito' em tese e não apenas no caso concreto, tal qual o fazem as comissões de constituição e justiça do Poder Legislativo ou o próprio Chefe do Poder Executivo (com o veto).

Assim, se efetuada uma consulta ao Tribunal por um legitimado (art. 264 do Regimento Interno do $\mathrm{TCU}^{186}$ ) e versar sobre matéria de conflito de lei ou ato normativo com a Constituição Federal, o Tribunal não pode se opor a declarar o direito perante o órgão jurisdicionado. Conforme o $\S 3^{\circ}$, a resposta à consulta a que se refere o artigo tem caráter normativo e constitui prejulgamento da tese, mas não do fato ou caso concreto.

Logo, não parece razoável que a Corte deixe de se pronunciar a respeito de possível inconstitucionalidade de textos legais editados, ficando no aguardo da execução da norma, para somente então, atacar os atos praticados, sob pena de se permitir a execução de ações com efeitos danosos ao patrimônio público ${ }^{187}$.

Se se admitir que os Tribunais de Contas $^{188}$ exercem tanto atividade jurisdicional como de fiscalização, no exercício do controle externo, então, no julgamento de contas e na apreciação da legalidade dos atos de registro, de fato, somente pode exercer

\footnotetext{
${ }^{186}$ Art. 264. O Plenário decidirá sobre consultas quanto a dúvida suscitada na aplicação de dispositivos legais e regulamentares concernentes à matéria de sua competência, que lhe forem formuladas pelas seguintes autoridades: I - presidentes da República, do Senado Federal, da Câmara dos Deputados e do Supremo Tribunal Federal; II - Procurador-Geral da República; III - Advogado-Geral da União; IV - presidente de comissão do Congresso Nacional ou de suas casas; V - presidentes de tribunais superiores; VI - ministros de Estado ou autoridades do Poder Executivo federal de nível hierárquico equivalente; VII - comandantes das Forças Armadas. § $1^{\circ}$ As consultas devem conter a indicação precisa do seu objeto, ser formuladas articuladamente e instruídas, sempre que possível, com parecer do órgão de assistência técnica ou jurídica da autoridade consulente. $\S 2^{\circ}$ Cumulativamente com os requisitos do parágrafo anterior, as autoridades referidas nos incisos IV, V, VI e VII deverão demonstrar a pertinência temática da consulta às respectivas áreas de atribuição das instituições que representam.

${ }^{187}$ FERNANDES, Jorge Ulisses Jacoby. Tribunais de Contas do Brasil: jurisdição e competência. $1^{\mathrm{a}} \mathrm{Ed} .2^{\mathrm{a}}$ tiragem. Belo Horizonte: Ed. Forum, 2003, p.290/291

${ }^{188}$ Há Capítulo específico para o tema 'Tribunal de Contas' no presente trabalho.
} 
o controle nos casos concretos, porém, no exercício das demais competências, nada obsta que aprecie a constitucionalidade das leis, em tese.

É fato que tal afirmação não corresponde ao entendimento dominante no Tribunal de Contas da União, que tem reafirmado a posição de somente apreciar a inconstitucionalidade em casos concretos, entretanto, há notícia de controle de constitucionalidade em tese no TC-006.005/1998-5 com decisão nº 171/1999, em Plenário, em consulta encaminhada pelo Senado Federal a respeito da legalidade de dispositivo da Medida Provisória no $1.625-51$ de 09 de abril de $1998^{189}$.

Enquanto ainda não dirimido o conflito pela Suprema Corte, o Tribunal de Contas permanece adotando decisões que permitem sua interferência no controle da constitucionalidade e com argumentos sólidos ${ }^{190}$.

189 FAJARDO, Cláudio Marcelo Spalla. Ob cit: Súmula STF no 346: Uma nova abordagem sobre a competência do TCU para apreciar a constitucionalidade de leis e de atos normativos do Poder Público. Revista do TCU. Ano 40. No 111 - Janeiro/Abril 2008, p.34

${ }^{190}$ Em decisão proferida pelo plenário do TCU no Acórdão nº379/2009 referente ao Processo 010.598/20066 de Incidente de Uniformização de Jurisprudência, foi discutido o tema e o Ministro Relator Aroldo Cedraz fez constar que: (...) discorre sobre a competência do Tribunal de Contas da União para negar vigência a normas inconstitucionais, nos seguintes termos: "De acordo com o art. 66, da Lei $n^{\circ}$ 8.443, de 1992, c/c o art. 15, inciso I, alínea e, do Regimento Interno do Tribunal de Contas da União, compete privativamente ao Plenário do TCU deliberar originariamente sobre "conflito de lei ou de ato normativo do poder público com a Constituição Federal, em matéria da competência do Tribunal". Nessa esteira, seguem-se os seguintes arestos ilustrativos que demonstram, à saciedade, a importância dessa competência desempenhada pelo Tribunal de Contas da União: Decisão 632/1994, Plenário, Ata 48/94 Plenário, Sessão de 11/10/1994, DOU de 7/11/1994 Página 16699; TC 006.005/1998-5, Decisão 171/1999 Plenário, DOU de 14/05/1999; TC 002.596/1999-7, decisão 188/1999 Plenário, DOU de 19/05/1999; e TC 001.609/1999-8, Decisão 429/1999 Plenário, DOU de 22/07/1999; TC 650.120/94-9. 4.4.3.1. Competência do TCU para negar vigência ao direito pré-constitucional. Parece-me não haver dúvida de que a ação do Tribunal de Contas da União, em matéria de sua exclusiva competência, como é o caso concernente a dirimir controvérsia sobre o direito préconstitucional em face do novo ordenamento jurídico constitucional, envolvendo direito à aposentadoria especial, junge-se ao seu poder decisório, mais precisamente ao seu Órgão Máximo, o Plenário, por força do art. 97 da Constituição Federal, c/c o art. 481, parágrafo único, do Código de Processo Civil (Lei $n^{o}$ 5.869, de 11/1/1973), aplicado de forma subsidiária e analógica pelo Tribunal de Contas da União por força da Súmula- TCU no 103. Impende mencionar, no entanto, que a competência do Tribunal de Contas da União para negar vigência a norma inconstitucional tem encontrado sólidas resistências no âmbito da Suprema Corte Constitucional, consoante se pode depreender das decisões adotadas no MS 25888 MC/DF DISTRITO FEDERAL, MEDIDA CAUTELAR NO MANDADO DE SEGURANÇA, Rel. Min. GILMAR MENDES, julgado em 22/3/2006, DJ de 29/3/2006, p. 11 e MS 26410 MC/DF DISTRITO FEDERAL MEDIDA CAUTELAR NO MANDADO DE SEGURANÇA, Rel. Min. RICARDO LEWANDOWSKI, julgado em 15/2/2007, DJ de 2/3/2007, p. 51. Considero, todavia, que as prerrogativas desta Corte de Contas em apreciar a constitucionalidade das leis e dos atos do Poder Público, inclusive para negar vigência ao direito pré-constitucional, nos termos da Súmula $n^{o} 347$ do STF, permanecem incólumes, tendo em vista que a Suprema Corte ainda não se pronunciou conclusivamente sobre a conveniência ou oportunidade de derrogar ou modificar o preceito sumulado. Dessa maneira, até que juizo definitivo seja pronunciado pela Suprema Corte em contrariedade ao entendimento do Tribunal de Contas da União, permanece a obrigação de a Administração Pública sujeitar-se ao Poder Regulamentar da Alta Corte de Contas, sob pena de responsabilização por eventual descumprimento de sua orientação. http://www.sindspem- 
Entretanto, o artigo 81 da Lei Complementar Estadual paulista $n^{\circ} 709 / 1993$ (Lei Orgânica do Tribunal de Contas do Estado) diz que se por ocasião do julgamento de qualquer feito por alguma das Câmaras do próprio Tribunal, for verificada a inconstitucionalidade de alguma lei ou ato do Poder Público, os autos serão remetidos para discussão em Sessão do Tribunal Pleno para pronunciamento preliminar sobre a matéria, sendo que na primeira Sessão Plenária o relator do feito exporá o caso, procedendo-se em seguida à deliberação e proferido o julgamento pelo Tribunal Pleno e publicada a respectiva deliberação, serão os autos devolvidos à Câmara, para apreciar o caso de acordo com a decisão prejudicial.

Além deste tema sobre as atribuições do Tribunal de Contas, o Capítulo 4 abordará as demais funções a ele acometidas.

\subsection{2 - Legitimidade}

Na linguagem comum, o termo legitimidade possui dois significados: um genérico e outro específico. No seu significado genérico, tem aproximadamente, o sentido de justiça ou de racionalidade (fala-se na legitimidade de uma decisão, de uma atitude, etc.). Na linguagem política é que aparece o significado específico e nesse contexto, o Estado é o ente a que mais se refere o conceito, sendo visto como um atributo do Estado, que consiste na presença, em uma parcela significativa da população, de um grau de consenso capaz de assegurar a obediência sem a necessidade de recorrer ao uso da força, a não ser em casos esporádicos.

É por essa razão que todo poder busca alcançar consenso, de maneira que seja reconhecido como legítimo, transformando a obediência em adesão. A crença na Legitimidade é, pois, o elemento integrador na relação de poder que se verifica no âmbito do Estado ${ }^{191}$.

ma.com.br/arquivos/file/comunicados/Decisao do TCU sobre Aposentadoria de Policial.pdf. acesso em 15-08-12

${ }^{191}$ Lucio Levy - Dicionário de Política - Universidade de Brasilia, in http://www.saudebucalcoletiva.unb.br/ensino/introducao_a ciencia_politica/8 3 Legitimidade.pdf - acesso em $03 / 08 / 12$ 
Tal abordagem aponta muito mais para aspecto sociológico do que jurídico, porém o sentimento de justiça traça identificação com fundamentos de moralidade e de valores intrínsecos aos princípios que regem a administração pública na busca do interesse público e do bem comum para efeito de aceitação do grau dos elementos de harmonia do grupo social.

A legitimidade difere da legalidade, da relação do poder com a lei estabelecida, porque se a legalidade é um requisito do exercício do poder, isto é, a justificação do respectivo exercício, a legitimidade é o requisito da titularidade do poder, a justificação do seu título ${ }^{192}$.

A legitimidade implica, assim, em reconhecer que o controle da fiscalização contábil, financeira, patrimonial e orçamentária não se limita ao aspecto formal, mas sim deve acontecer de forma mais profunda quanto ao conteúdo e à substância do ato.

Aproxima-se de um sentido de justiça e de racionalidade no exercício da atividade financeira e patrimonial, englobando princípios constitucionais orçamentários e financeiros além daqueles afetos ao patrimônio envolvidos com a ideia de segurança jurídica. ${ }^{193}$.

Pondera, ainda com questões referentes à impessoalidade, interesse público, e princípios não jurídicos de uma boa administração.

Para Ricardo Lobo Torres, a “análise do exato cumprimento do princípio da capacidade contributiva, que manda cobrar impostos de acordo com a situação e a riqueza de cada um, do princípio da redistribuição de rendas, que proclama a necessidade da justiça distributiva, do princípio do equilíbrio financeiro, que postula a adequação entre receita e despesa para a superação das crises provocadas pelo endividamento público, por exemplo, participa do controle de legitimidade" ${ }^{194}$.

192 http://farolpolitico.blogspot.com.br/2007/10/legitimidade_12.html. Acesso em 03/08/12

193 MILESKI, Helio Saul. O Controle da Gestão Pública. São Paulo: RT. 2003, p.249

194 TORRES, Ricardo Lobo, A legitimidade tributária e o Tribunal de Contas, Revista de Direito Administrativo 194/31-45, Rio de Janeiro, out-dez. 1993. 
A respeito da legitimidade, o Tribunal de Contas da União firmando sua competência para fiscalização de empresa incorporada ao Patrimônio Nacional, editou a Súmula no 180 (publicada no DOU de 09/11/1982) que diz que “ainda que não recebam contribuições parafiscais ou transferências à conta da União e independentemente da sua natureza jurídica, estão sujeitas ao exame e julgamento do Tribunal de Contas as contas das empresas privadas, cuja totalidade ou maioria das ações ordinárias, representativas do seu capital social, foram desapropriadas pela União, ou cujos bens, integrantes do seu patrimônio, foram confiscados e incorporados ao patrimônio da União, na forma da lei, verificando-se, nos respectivos processos de prestação de contas, a legitimidade das operações que conduziram à desapropriação ou ao confisco, a situação das contas antes da intervenção e quando sob gestão do interventor, controlador, executor do confisco ou liquidante".

Chama a atenção a exigência da verificação, junto aos processos de prestação de contas, da legitimidade das operações que conduziram à desapropriação ou ao confisco, indicando um pressuposto de validação do ato para emprestar requisito de justificação para a intervenção da Corte de Contas.

\subsection{3 - Economicidade}

De conceituação mais técnica que os demais, envolve genericamente os custos relativos aos objetivos que se pretende alcançar, implicando em reconhecer a otimização da relação custo/benefício.

Entretanto, distintamente da esfera privada em que se pensa em relação custo/lucro, no setor público observa-se a relação custo/benefício, até porque não seria equivocado afirmar que o poder público obtém `lucro`quanto maior o benefício social que lograr atingir.

Aproxima-se do conceito de eficiência, significando que, a administração pública deve procurar realizar o interesse público com o menor custo social possível e ao mesmo tempo beneficiando, da melhor forma que puder, o maior número de administrados. 
A título de exemplo, há previsão na Lei de Responsabilidade Fiscal quando trata de renúncia de receita ${ }^{195}$ para determinar que ela não poderá acontecer quando há o cancelamento de um débito cujo montante seja inferior ao dos respectivos custos de cobrança (art. $14, \S 3^{\circ}$, II).

Há, por meio do controle da economicidade uma avaliação sobre a eficiência na gestão financeira e na execução orçamentária diante da minimização de custos e gastos e maximização de receitas. Analisa sob os dois aspectos: o ingresso do dinheiro obtido na sociedade e sua melhor destinação.

Publicação da Fundação Getúlio Vargas - "FGV Uma Ferramenta para a Eficácia da Gestão ${ }^{196}$, indicou conceito de economicidade como sendo:

"Economicidade é um vocábulo que só aparece nas edições mais recentes dos dicionários, com a definição: -"Economicidade é a qualidade ou o caráter de ser econômico". No Michaelis esta palavra tem o conceito ampliado para: Economicidade é o princípio de natureza essencialmente gerencial, intrínseco à noção de eficiência, eficácia e efetividade na gestão de recursos e bens. Trata-se da obtenção do melhor resultado possível para uma determinada alocação de recursos físicos, financeiros, econômicos, humanos e tecnológicos em um dado cenário sócio-econômico. Entretanto, José Affonso, em 1975, época em que o vocábulo não constava do dicionário, já havia cunhado este termo com uma visão ainda mais ampla, que se prende à natureza da otimização de recursos em atingir quaisquer objetivos desejados por uma organização ou grupo.'

Pode-se mesmo dizer, lembrando o exemplo formulado acerca da ponte construída em um município, que, diante da afirmação de que existe limitação da discricionariedade do administrador público, como na hipótese de que diante de mais de uma situação possível, posta em um caso concreto, deverá optar por aquela que privilegie a economicidade, o responsável se vê obrigado a optar pela opção que evite gastos

\footnotetext{
${ }_{196}^{195}$ Conceito que será visto adiante.
}

http://www.fgv.br/fgvprojetos/economicidade/arq/Aspectos\%20Gerais\%20FGV\%20Economicidade\%203mai2005.pdf Acesso em março de 2009 - Extraído de promoção de arquivamento nos autos do Protocolado no 201/09 da Promotoria de Justiça do Patrimônio Público e Social de São Paulo, que esteve sob responsabilidade do autor. 
desnecessários (preços acima dos praticados no mercado) e escolhas sem cautela geradoras de desperdício.

Para ilustrar o tema da economicidade, mencione-se o Acórdão n ${ }^{\circ}$ 279/00 do TCU $^{197}$ que analisou compra de equipamentos de informática (notebooks) com licitação reconhecidamente regular, porém com preço $100 \%$ maior que o praticado no próprio estabelecimento do contratado. Tendo em vista o decréscimo do valor de mercado do bem com o tempo passado entre a abertura do procedimento e a data do pagamento da compra do produto (oito meses), seria cabível a revogação da licitação (art. 49 da Lei n 8.666/93) ou sua dispensa (art. 24, VII), visando preservar o interesse público, permitindo à administração pública buscar proposta mais vantajosa. Consigne-se que o voto do relator mencionou a obsolescência do produto de informática com a demora. O responsável foi, então, multado pelo Tribunal.

Outra decisão que se pautou pela violação da economicidade diz respeito à manutenção de equipamentos ${ }^{198}$. Considerou o TCU que seria antieconômica a contratação de serviços de manutenção de equipamentos de informática, ar condicionado e veículos por preços globais, que possibilitariam, no curso da vigência dos contratos, a aquisição de produtos novos e com garantia, em quantidade superior às então existentes no órgão (no caso, Funasa/AP), objeto das avenças. A decisão refere que são requisitos do ato administrativo a forma e o seu objeto e que com relação à terceirização de atividade no âmbito da administração pública $\mathrm{o}$ art. $2^{\circ}$ do Decreto $\mathrm{n}^{\circ} 2.271 / 97$ estabelece que a contratação deveria ser precedida de um plano de trabalho aprovado pela autoridade competente, contendo, obrigatoriamente, a justificativa da necessidade dos serviços, relação entre a demanda prevista e a quantidade de serviço a ser contratado e demonstrativo de resultados a serem alcançados em termos de economicidade e melhor aproveitamento dos recursos humanos, materiais e financeiros. O relatório não foi anexado pelos responsáveis assim como o plano de trabalho, resultando em multa aplicada pelo órgão fiscalizador.

\footnotetext{
${ }^{197}$ TCU, Acórdão no 279/00. Plenário: AC-0279-43/00-p, in DOU de 14.11.00, mencionado in BUGARIN, Paulo Soares. O princípio constitucional da Economicidade na jurisprudência do Tribunal de Contas da União. Belo Horizonte: Ed. Forum, 2004.

${ }^{198}$ TCU. Acórdão no 128/00. Plenário: AC-0128-32/99-p - DOU de 05.08.99, mencionado in BUGARIN, Paulo Soares. O princípio constitucional da Economicidade na jurisprudência do Tribunal de Contas da União. Belo Horizonte: Ed. Forum, 2004.
} 
Em outro exemplo o $\mathrm{TCU}^{199}$ considerou contrário à economicidade a manutenção de imóvel desocupado no patrimônio público, visto que as despesas de vigilância, contadas ao longo do tempo, ultrapassaram o valor do bem. Ainda que admitindo espaço de competência privativa do administrador público no que tange ao destino a ser dado ao imóvel, quando o relator reconheceu que "não seria próprio substituir o discricionarismo do administrador pelo do TCU', negando assim, ao Tribunal a possibilidade de dizer o que deveria ser feito com o imóvel (e que se encontrava sob disputa judicial) houve a sugestão ao administrador (cuja boa fé foi admitida) para estudos da conveniência acerca da alienação do imóvel, diligenciando-se no sentido de obtenção de autorização judicial, como garantia.

\subsection{4 - Aplicação de Subvenções}

As subvenções, auxílios ou contribuições constituem meios de cooperação financeira entre a União e entidades públicas ou privadas. A transferência é feita a fundo perdido, pretendendo atingir objetivos de interesse público, especialmente na área social, por intermédio de terceiros, conforme o Decreto no 93.872/86.

As subvenções destinam-se a cobrir despesas de custeio de entidades públicas ou privadas e podem ser sociais ou econômicas. As primeiras são concedidas a instituições de caráter cultural ou assistencial sem finalidade lucrativa, enquanto que as últimas beneficiam empresas de caráter industrial, comercial, agrícola ou pastoril. Os auxílios e as contribuições, por sua vez, são transferências de capitais destinados a investimentos ou inversões financeiras para entidades sem fins lucrativos.

Tais transferências são reguladas pela Lei de Diretrizes Orçamentárias (LDO), que discrimina os requisitos para a concessão e utilização dos recursos envolvidos e estar prevista no Orçamento ou seus créditos adicionais, conforme prevê o artigo 26 da Lei de Responsabilidade Fiscal ${ }^{200}$.

${ }^{199}$ TCU. Acórdão no 097/97. Plenário: DC-0098-09/97-p - DOU de 08.04.97, mencionado in BUGARIN, Paulo Soares. O princípio constitucional da Economicidade na jurisprudência do Tribunal de Contas da União. Belo Horizonte: Ed. Forum, 2004.

${ }^{200}$ Prevê a Lei de Diretrizes Orçamentárias (Lei no 12.708 de 17 de agosto de 2012) que: Art. 55. Sem prejuízo das disposições contidas nos arts. 51 a 54 desta Lei, a transferência de recursos prevista na Lei no 4.320, de 1964, a entidade privada sem fins lucrativos, nos termos do disposto no §3o do art. 12 da Lei no 9.532, de 10 de dezembro de 1997, dependerá da justificação pelo órgão concedente de que a entidade 
Devem ser, também fiscalizadas quanto à regularidade e legalidade da aplicação correspondente, assim competindo, em decorrência do disposto no inciso II do art. 74 da Constituição Federal, ao controle interno do órgão repassador, além de necessitar de lei específica relatando qual será a entidade a beneficiada, o valor a ser repassado e o objetivo do repasse.

O Tribunal de Contas fiscaliza a aplicação dos recursos em questão por ocasião do exame dos processos de tomadas ou prestações de contas do órgão ou entidade transferidor dos recursos. Essa fiscalização compreende as fases de concessão, utilização e prestação de contas.

complementa de forma adequada os serviços prestados diretamente pelo setor público e ainda de: I aplicação de recursos de capital exclusivamente para: a) aquisição e instalação de equipamentos e obras de adequação física necessárias à instalação dos referidos equipamentos; e b) aquisição de material permanente; II - identificação do beneficiário e do valor transferido no respectivo convênio ou instrumento congênere; III - execução na modalidade de aplicação 50 - transferência a entidade privada sem fins lucrativos; IV compromisso da entidade beneficiada de disponibilizar ao cidadão, na sua página na internet ou, na falta desta, em sua sede, consulta ao extrato do convênio ou instrumento congênere, contendo, pelo menos, o objeto, a finalidade e o detalhamento da aplicação dos recursos; V - apresentação da prestação de contas de recursos anteriormente recebidos, nos prazos e nas condições fixados na legislação e inexistência de prestação de contas rejeitada; VI - publicação, pelo Poder respectivo, de normas, a serem observadas na concessão de subvenções sociais, auxílios e contribuições correntes, que definam, entre outros aspectos, critérios objetivos de habilitação e seleção das entidades beneficiárias e de alocação de recursos e prazo do benefício, prevendo-se, ainda, cláusula de reversão no caso de desvio de finalidade; VII - comprovação pela entidade da regularidade do mandato de sua diretoria, além da comprovação da atividade regular nos últimos três anos, por meio da declaração de funcionamento regular da entidade beneficiária, inclusive com inscrição no CNPJ, emitida no exercício de 2013 por três autoridades locais sob as penas da lei; VIII - cláusula de reversão patrimonial, válida até a depreciação integral do bem ou a amortização do investimento, constituindo garantia real em favor do concedente em montante equivalente aos recursos de capital destinados à entidade, cuja execução ocorrerá caso se verifique desvio de finalidade ou aplicação irregular dos recursos; IX - manutenção de escrituração contábil regular; X - apresentação pela entidade de certidão negativa ou certidão positiva com efeito de negativa de débitos relativos aos tributos administrados pela Secretaria da Receita Federal do Brasil e à dívida ativa da União, certificado de regularidade do Fundo de Garantia do Tempo de Serviço - FGTS e de regularidade em face do Cadastro Informativo de Créditos não Quitados do Setor Público Federal - CADIN; XI - demonstração, por parte da entidade, de que apresenta capacidade gerencial, operacional e técnica para desenvolver as atividades, informando a quantidade e a qualificação profissional de seu pessoal; e XII - manifestação prévia e expressa do setor técnico e da assessoria jurídica do órgão concedente sobre a adequação dos convênios e instrumentos congêneres às normas afetas à matéria. $\S 1^{\circ}$ A determinação contida no inciso I do caput não se aplica aos recursos alocados para programas habitacionais, conforme previsão em legislação específica, em ações voltadas a viabilizar o acesso à moradia, bem como na elevação de padrões de habitabilidade e de qualidade de vida de famílias de baixa renda que vivem em localidades urbanas e rurais. $\S 2^{\circ}$ A exigência constante do inciso III do caput não se aplica quando a transferência dos recursos ocorrer por intermédio de fundos estaduais, distrital e municipais, nos termos da legislação pertinente. $\S 3^{\circ} \mathrm{A}$ destinação de recursos a entidade privada não será permitida nos casos em que agente político de Poder ou do Ministério Público, tanto quanto dirigente de órgão ou entidade da administração pública, de qualquer esfera governamental, ou respectivo cônjuge ou companheiro, bem como parente em linha reta, colateral ou por afinidade, até o segundo grau, seja integrante de seu quadro dirigente, ressalvados os casos em que a nomeação decorra de previsão legal ou que sejam beneficiados. 
Se houver omissão na prestação de contas ou de irregularidade na aplicação dos recursos, a autoridade administrativa competente deve instaurar tomada de contas especial, a ser julgada pelo Tribunal, para apuração dos fatos, identificação dos responsáveis e quantificação do dano.

Aliás, encontra-se em decisão do Tribunal Federal de Recursos ${ }^{201}$ que nos termos do art.12, $\$ 3^{\circ}$, da Lei $\mathrm{n}^{\mathrm{o}} 4.320 / 64$, as subvenções sociais são transferência de recursos públicos para cobrir despesas de custeio de instituições públicas ou privadas de caráter assistencial ou cultural, sem finalidade lucrativa e que o seu recebimento submete a entidade recebedora à comprovação de sua correta aplicação (conforme art. 93 do Decretolei $n^{\circ} 200 / 67$ e art. 66 do Decreto $n^{\circ}$ 93.872/86), sendo que se constatada a irregularidade das contas prestadas pelo subvencionado, a instauração de processo de Tomada de Contas Especial no TCU não configura cerceamento de defesa, eis que a oportunidade para a apresentação de alegações ocorre após a instauração do referido procedimento, e não durante a verificação das contas.

Segundo ainda as Normas Brasileiras de Contabilidade (nos termos da NBCT 19.4 que trata de subvenções e assistências governamentais) ${ }^{202}$ subvenção governamental é uma assistência governamental geralmente na forma de contribuição de natureza pecuniária, mas não só restrita a ela, concedida a uma entidade normalmente em troca do cumprimento passado ou futuro de certas condições relacionadas às atividades operacionais da entidade. Não são subvenções governamentais aquelas que não podem ser razoavelmente quantificadas em dinheiro e as transações com o governo que não podem ser distinguidas das transações comerciais normais da entidade.

O propósito da assistência pode ser o de encorajar a entidade a seguir certo rumo que ela normalmente não teria tomado se a assistência não fosse proporcionada e a contabilização deve sempre seguir a essência econômica.

O recebimento da assistência governamental por uma entidade pode ser significativo para a preparação das demonstrações contábeis em razão da necessidade de

\footnotetext{
${ }^{201}$ TRF2 - Apelação Cível - AC 200202010125983, RJ 2002.02.01.012598-3.

${ }^{202}$ http://www.normaslegais.com.br/legislacao/resolucaocfc1143_2008.htm - Acesso em 23/07/12.
} 
identificar método apropriado para sua contabilização, bem como para indicar a extensão pela qual a entidade se beneficiou de tal assistência durante o período coberto pelas demonstrações. Isso permite a comparação das demonstrações contábeis entre períodos e entre entidades diferentes.

A subvenção governamental é também designada por: subsídio, incentivo fiscal, doação, prêmio, etc. e mesmo que seja subvenção não monetária a valor justo, não deve ser reconhecida até que exista segurança de que a entidade cumprirá todas as condições estabelecidas e a subvenção será recebida.

Entretanto o simples recebimento da subvenção não é prova conclusiva de que as condições a ela vinculadas tenham sido ou serão cumpridas, enquanto que a forma como a subvenção é recebida não influencia no método de contabilização a ser adotado. Assim, por exemplo, a contabilização deve ser a mesma independentemente de a subvenção ser recebida em dinheiro ou como redução de passivo.

Subsídio em empréstimo é reconhecido como subvenção governamental quando existir segurança de que a entidade cumprirá os compromissos assumidos. Essa segurança de atendimento a compromissos assumidos geralmente pode ser demonstrada pela administração apenas nos casos em que esses compromissos dependem exclusivamente de providências internas da entidade, por serem mais confiáveis e viáveis ou, ainda, melhor administráveis do que requisitos que envolvam terceiros ou situação de mercado. Desse modo, é provável que as condições históricas ou presentes da entidade demonstrem, por exemplo, que pagamentos dentro de prazos fixados podem ser realizados e dependem apenas da intenção da administração. Por outro lado, requisitos que dependem de fatores externos, como a manutenção de determinado volume de venda ou nível de emprego, não podem ser presentemente determináveis e, portanto, a subvenção apenas deve ser reconhecida quando cumprido o compromisso.

Uma subvenção governamental deve ser admitida como receita ao longo do período confrontada com as despesas que pretende compensar, em base sistemática, desde que atendidas às condições da referida Norma. A subvenção governamental não pode ser creditada diretamente no patrimônio líquido. 
O tratamento contábil da subvenção governamental como receita deriva dos seguintes principais argumentos: (a) Uma vez que a subvenção governamental é recebida de uma fonte que não os acionistas e deriva de ato de gestão em benefício da entidade, não deve ser creditada diretamente no patrimônio líquido, mas, sim, reconhecida como receita nos períodos apropriados. (b) Subvenção governamental apenas excepcionalmente é gratuita. A entidade ganha efetivamente essa receita quando está de acordo com as regras das subvenções e cumpre determinadas obrigações. (c) Assim como os tributos são lançados no resultado, é lógico registrar a subvenção governamental, que é, em essência, uma extensão da política fiscal na demonstração do resultado.

Sob a ótica do tema patrimonial, é sabido que a subvenção governamental pode estar representada por ativo não monetário, como terrenos e outros, para uso da entidade. Nessas circunstâncias, esse ativo deve ser reconhecido pelo seu valor justo ${ }^{203}$. Apenas na impossibilidade de verificação desse valor justo pode ser a atribuição de valor nominal.

O reconhecimento da subvenção como um terreno, por exemplo, não pode ser efetuado diretamente em conta de resultado, ficando então temporariamente em conta de passivo, uma vez que os benefícios econômicos pela utilização daqueles ativos somente são obtidos por seu uso ou sua alienação, a não ser no caso de ativo não depreciável, amortizável ou exaurível, e desde que completamente desvinculado de qualquer obrigação e sem possibilidade objetiva de vinculação com os benefícios econômicos derivados de sua utilização.

Neste sentido, para efeito de fiscalização contábil, são considerados aceitáveis dois métodos de apresentação nas demonstrações contábeis de subvenção (ou parte apropriada de subvenção) não vinculada a obrigações futuras, relacionada com ativos.

Um deles considera a subvenção como receita diferida no passivo, sendo reconhecida como receita em base sistemática e racional durante a vida útil do ativo e o outro deduz a contrapartida do próprio ativo recebido como subvenção para se chegar ao valor escriturado líquido do ativo, que pode ser nulo. A subvenção é reconhecida como

\footnotetext{
${ }^{203}$ Expressão com caráter subjetivo, pode ser objetivada, por exemplo com avaliação de um imóvel por mais de uma agência de corretor de imóveis.
} 
receita durante a vida do ativo depreciável por meio de crédito à depreciação registrada no resultado.

A compra de ativo e o recebimento da subvenção a ele relacionada pode causar movimentos importantes nos fluxos de caixa de uma entidade. Por essa razão, e a fim de mostrar o investimento bruto em ativos, tais movimentos são frequentemente divulgados como itens separados na demonstração dos fluxos de caixa independentemente de a subvenção ser, ou não, deduzida do respectivo ativo na apresentação do balanço patrimonial.

Importa fixar que devem existir controles internos para que o ente público realize as subvenções sociais dentro das normas legais, evitando as fraudes e avaliando se, realmente, o gasto efetuado trouxe benefícios ao cidadão.

Assim, verifica-se ${ }^{204}$ que a entidade interessada deverá apresentar um plano de trabalho, que será analisado pela administração (gestora dos recursos) no que tange ao interesse público (finalidade) e à compatibilidade com os objetivos dos programas de governo. Após esta apreciação, dito plano de trabalho deverá ser encaminhado para o respectivo conselho municipal (se for o caso: saúde, assistência, educação, etc.) para apreciação e, sendo o caso, aprovação. Além do plano de aplicação, devem ser observados os critérios estabelecidos na LDO para fins de repasse como, por exemplo, que a entidade seja sem fins lucrativos, apresente estatuto social, provas de regularidade fiscal com a Previdência Social e Fundo de Garantia do Tempo de Serviço - FGTS e balanço ou demonstrações financeiras do exercício anterior.

Na União, as exigências de apresentação de informações sobre as entidades também estão previstas no Decreto Federal $n^{\circ}$ 6.170, de 2007, em seu artigo $3^{\circ}$, além da própria LDO. Após o deferimento da administração em relação ao pedido, deverá ser encaminhado o projeto de lei específico ao legislativo para fins de definição de valores a serem repassados, da finalidade do repasse, quais as entidades beneficiadas e o período do benefício. Com a aprovação da Lei de repasse da subvenção, o ente público deverá firmar

${ }^{204}$ Tema este amplamente referido no artigo: Aspectos Legais e Controles nas Subvenções Sociais ao Terceiro Setor, por Dalberto Andretta, in Revista de Negócios/Business Review - ISSN 1980/2080 - $\mathrm{n}^{\circ} 09$, Março 2010 - http://www.unifin.edu.br/Content/arquivos/20111006204404.pdf - Acesso em 30/07/12. 
um convênio com a entidade de acordo com os requisitos mencionados no art. 116 da Lei Federal nº 8.666, de 1993, e alterações.

Sugere-se que o órgão responsável pela análise da prestação de contas, ou outro órgão definido pela administração, oriente os procedimentos às entidades, tanto no que diz respeito à forma adequada para a aplicação dos recursos na execução do plano de trabalho, como o conteúdo e a forma de apresentação da prestação de contas (documentos que devem integrar), de maneira que seja evitada a sua devolução ou rejeição.

Salienta-se a necessidade de uma legislação local sobre esse assunto, padronizando os planos de trabalhos, os prazos de prestações de contas, a documentação necessária e as demais exigências para o bom controle interno.

Como exemplos do que está previsto no art. 10 do Decreto Federal n 6.170, de 2007, temos: os pagamentos aos fornecedores das entidades subvencionadas somente serão realizados com depósito em conta bancária e excepcionalmente as pessoas físicas que não possuem conta bancária devem receber mediante mecanismo que permita a identificação pelo banco do beneficiário do pagamento; as entidades deverão efetuar cotação dos serviços antes da celebração do contrato com o fornecedor, o conveniente será obrigado prestar contas no prazo de 30 dias dos recursos recebidos e assim por diante.

É possível se mencionar a existência de controles internos específicos conforme o tipo de entidade que receberá os recursos, de acordo com o objeto de gasto ou período de repasse dos mesmos ${ }^{205}$.

Assim, nos repasses às instituições comunitárias, confessionais ou filantrópicas sem fins lucrativos na área de educação deverão ser observadas as exigências do art. $8^{\circ}$ da Lei Federal $n^{\circ} 11.494$, de 2007 - FUNDEB - que determina que as entidades devem oferecer igualdade de condições para o acesso e permanência na escola e atendimento educacional gratuito a todos os seus alunos; comprovar finalidade não lucrativa e aplicar seus excedentes financeiros em educação infantil e especial; assegurar a

205 Artigo: Aspectos Legais e Controles nas Subvenções Sociais ao Terceiro Setor, por Dalberto Andretta, in Revista de Negócios/Business Review - ISSN 1980/2080 - nº 09, Março 2010.

http://www.unifin.edu.br/Content/arquivos/20111006204404.pdf - Acesso em 30/07/12. 
destinação de seu patrimônio a outra escola comunitária, filantrópica ou confessional com atuação na educação infantil e especial ou ao poder público no caso do encerramento de suas atividades; atender os padrões mínimos de qualidade definidos pelo órgão normativo do sistema de ensino, inclusive, obrigatoriamente, ter aprovados seus projetos pedagógicos e ter certificado do Conselho Nacional de Assistência Social ou órgão equivalente, na forma do regulamento.

E em relação às subvenções em ano eleitoral, deverá ser observado o $§ 10^{\circ}$, do artigo 73, da Lei Federal $n^{\circ}$ 9.504, de 1997, que proíbe a distribuição gratuita de valores, exceto em estado de calamidade pública, emergência ou que, no exercício anterior ao pleito, já tenha ocorrido um mesmo repasse com o objetivo que se pretender realizar no ano da eleição.

Quanto aos repasses às OS e às OSIPS, deve-se observar a existência do contrato de gestão e do termo de parceria, respectivamente, em substituição ao convênio. $\mathrm{O}$ contrato de gestão, conforme art. $7^{\circ}$ da Lei Federal $n^{\circ}$ 9.637, de 1998, deve conter os seguintes requisitos mínimos: a) especificação do programa de trabalho proposto pela organização social, a estipulação das metas a serem atingidas e os respectivos prazos de execução, bem como previsão expressa dos critérios objetivos de avaliação de desempenho a serem utilizados, mediante indicadores de qualidade e produtividade, e b) estipulação dos limites e critérios para despesa com remuneração e vantagens de qualquer natureza a serem percebidas pelos dirigentes e empregados no exercício de suas funções.

Já o termo de parceria deve ser elaborado de acordo com as cláusulas previstas no art. $10, \S 2^{\circ}$, da Lei Federal $n^{\circ}$ 9.790, de 1999: a) o objeto, com especificação do programa de trabalho proposto pela organização da sociedade civil de interesse público; b) metas e resultados a serem atingidos e respectivos prazos de execução ou cronogramas; c) critérios objetivos de avaliação de desempenho a serem utilizados, mediante indicadores de resultado; d) receitas e despesas a serem realizadas em seu cumprimento, com estipulação de categorias contábeis a serem usadas pela organização, e detalhamento de remunerações e benefícios de pessoal a serem pagos a seus diretores, empregados e consultores; e) as obrigações da sociedade civil de interesse público, e f) a publicação, na imprensa oficial do Município, do Estado, ou da União, conforme o alcance das atividades celebradas, do extrato do termo de parceria e de demonstrativo de sua execução física e 
financeira, conforme modelo simplificado estabelecido no Decreto Federal $n^{0} 3.100$, de 1999.

A contratação de organizações sociais é dispensada pela Lei de Licitações em seu artigo 24, XXIV, enquanto que na contratação de OSCIP deverá ser realizado um concurso de projetos, nos termos dos artigos 23 e seguintes do Decreto Federal no 3.100, de 1999.

Apesar de todos estes controles formais sabe-se que a fraude pode ocorrer através de apresentações de notas fiscais emitidas por empresas fictícias, demonstrando que no papel que tudo está certo, mas na realidade o serviço ou o atendimento pactuado com a entidade não aconteceu. Com isso o sistema de controle interno deve também avaliar os resultados gerados pelos recursos repassados, verificando através de indicadores de desempenho, metas, etapas, o atendimento do objeto pactuado com a entidade solicitante e se possível com verificação em loco do serviço realizado ou prestado, enquanto que o controle externo acontecerá também para coibir os mesmos tipos de problemas.

A subvenção governamental pode ser perdida e, neste caso terá de ser devolvida, quando então deve ser contabilizada como revisão de estimativa contábil, conforme a "NBC T 19.11 - Mudanças nas Práticas Contábeis, nas Estimativas e Correção de Erros". O reembolso deve ser aplicado em primeiro lugar contra qualquer crédito diferido não amortizado relacionado à subvenção. Na medida em que o reembolso exceda tal crédito diferido, ou quando não exista crédito diferido, o reembolso deve ser reconhecido imediatamente como despesa. O reembolso de subvenção relacionada a ativo deve ser registrado aumentando o valor escriturado do ativo ou reduzindo o saldo da receita diferida pelo montante reembolsável, e a depreciação adicional acumulada que deveria ter sido reconhecida até a data como despesa na ausência da subvenção deve ser imediatamente reconhecida como despesa, sendo que perante as circunstâncias que dão origem ao reembolso de subvenção relacionada com ativo, pode ser necessário reconhecer perda de valor do ativo.

Finalmente, a entidade beneficiada deve atender a publicidade, divulgando as seguintes informações: (a) a política contábil adotada para as subvenções 
governamentais, incluindo os métodos de apresentação adotados nas demonstrações contábeis; (b) a natureza e os montantes reconhecidos das subvenções governamentais ou das assistências governamentais, bem como a indicação de outras formas de assistência governamental de que a entidade tenha diretamente se beneficiado; (c) condições a serem regularmente satisfeitas ligadas à assistência governamental que tenha sido reconhecida; (d) descumprimento de condições relativas às subvenções ou existência de outras contingências; (e) eventuais subvenções a reconhecer contabilmente, após cumpridas as condições contratuais; (f) premissas utilizadas para o cálculo do valor justo exigido pela Norma contábil; (g) informações relativas às parcelas aplicadas em fundos de investimentos regionais e às reduções ou isenções de tributos em áreas incentivadas.

\subsection{5 - Renúncia de Receitas}

A renúncia de receitas constitui-se em um gasto ou assistência financeira indireta do Governo, com a particularidade de ter sido realizada via redução da carga tributária. A Constituição Federal, embora não fazendo remissão expressa ao termo renúncia de receitas, estabeleceu no seu art. 150, parágrafo sexto, que qualquer subsídio ou isenção, redução de base de cálculo, concessão de crédito presumido, anistia ou remissão, relativos a impostos, taxas ou contribuições, só poderá ser concedido mediante lei específica, federal, estadual ou municipal, que regule exclusivamente as matérias acima enumeradas ou o correspondente tributo ou contribuição.

Já a Lei Complementar no 101/2000 trata no art. 14 que a concessão ou ampliação de incentivo de natureza tributária da qual decorra renúncia de receita deverá estar acompanhada de estimativa do impacto orçamentário e financeiro no exercício que deva iniciar sua vigência e nos dois seguintes, bem como atender ao disposto na lei de diretrizes orçamentárias. Estabelece no parágrafo $1^{\circ}$ do citado artigo as modalidades de renúncia de receita, compreendendo: anistia, remissão, subsídio, crédito presumido, concessão de isenção em caráter não geral, alteração de alíquota ou modificação de base de cálculo que implique redução discriminada de tributos ou contribuições, e outros benefícios que correspondam a tratamento diferenciado. 
A renúncia implica em desistência do direito de cobrar um crédito tributário (na sua totalidade ou parcialmente), manifestada pelo Ente que possui competência para instituição do tributo.

É pela concessão de incentivos fiscais que, via de regra se opera a renúncia de receita. Encontra-se regulada na Constituição Federal por meio de duas normas, uma de natureza tributária (art. 150, $\left.\S 6^{\circ}\right)$, outra de natureza financeira $\left(\operatorname{art.165}, \S 6^{\circ}\right.$ ). A norma do art. $150, \S 6^{\circ}$, da CF, exige Lei específica e do Ente Político que tem competência para a instituição do tributo, para concessão de qualquer forma de renúncia de receita, classificando-as em: subsídio, isenção, redução de base de cálculo, concessão de crédito presumido, anistia ou remissão. A norma (financeira) do art. $165, \S 6^{\circ}$, da $\mathrm{CF}$, exige o relatório de impacto dos efeitos gerados pela renúncia de receita, no orçamento, como documento que deve acompanhar o projeto de Lei Orçamentária, nominando a renúncia como sendo: isenções, anistias, remissões, subsídios e benefícios de natureza tributária, financeira e creditícia.

"Os incentivos fiscais, em princípio, são instrumentos de que dispõe o Poder Público para promover o desenvolvimento da economia e possibilitar o incremento de empregos em determinada faixa do território onde são aplicados. Implicam redução do montante devido pelo contribuinte que ostenta a condição de beneficiário, mediante isenção, anistia, remissão e outras concessões permitidas legislativamente ${ }^{\text {,206. }}$.

Consta $^{207}$ afirmação de que a partir da $2^{\mathrm{a}}$ Edição do Manual de Procedimentos da Receita Pública - Aplicado à União, Estados, Distrito Federal e Municípios, elaborado pela Secretaria do Tesouro Nacional do Ministério da Fazenda STN/MF em 2005 (para ser, então aplicado quando da elaboração da lei orçamentária para 2006 e sua respectiva execução), no âmbito do item 8.3 - Renúncia de Receita, metodologia com vistas a registrar essas renúncias de receita, conforme a seguir transcrito: "Para demonstrar aos usuários da informação contábil a existência e o montante dos recursos que o ente tem a competência de arrecadar, mas não ingressam nos cofres

\footnotetext{
${ }^{206}$ NASCIMENTO,Carlos Valder do, et alii. Comentários à Lei de Responsabilidade Fiscal. Organizadores: MARTINS,Ives Gandra da Silva e NASCIMENTO, Carlos Valder do. São Paulo: Saraiva, 2001, p.95.

${ }^{207}$ Evidenciação das renúncias de receitas tributárias federais pela Contabilidade Pública: importância e dificuldades. Por Júlio César Azevedo Teixeira. Brasília, DF. 2006 in.

http://portal2.tcu.gov.br/portal/pls/portal/docs/2055712.PDF. Acesso em 30/07/12
} 
públicos, poderá ser utilizada a metodologia de dedução de receita. Dessa forma, deverá haver um registro contábil de natureza de receita objeto da renúncia em contrapartida com uma dedução de receita (conta retificadora de receita).

Júlio César Azevedo Teixeira ${ }^{208}$ diz que não obstante a relevância material e qualitativa que justificam a contabilização das renúncias de receitas tributárias, tendo em vista a própria natureza dessas renúncias, no sentido de que elas não ingressam nos cofres públicos, à exceção daquelas voltadas aos Fundos de Investimentos Regionais, verificamse diversas dificuldades a serem transpostas com vistas ao efetivo registro e evidenciação dos respectivos valores renunciados em nível federal. Primeiramente, deve-se ressaltar a falta de informação tempestiva a respeito das renúncias de receitas que não ingressam nos cofres públicos. Segundo consta do Demonstrativo de Gastos Governamentais Indiretos de Natureza Tributária (2006), elaborado pela SRF, esses dados são originários, basicamente, de dados prestados pelos contribuintes por meio das respectivas declarações dos impostos federais.

Refere que para a elaboração do mencionado demonstrativo, a Secretaria da Receita Federal utiliza informações encaminhadas por órgãos federais responsáveis pelo controle e acompanhamento da concessão de determinados benefícios tributários como, por exemplo, Ministério da Ciência e Tecnologia, em relação aos incentivos para o setor de informática, e o Ministério da Cultura, quanto aos benefícios voltados à cultura. Essas informações prestadas pelos referidos órgãos geralmente são extraídas de dados concernentes a projetos aprovados por eles relativamente aos incentivos tributários nas respectivas áreas de atuação. Ressalta-se que, em vários casos, as informações originárias desses órgãos substituem os dados contidos nas declarações entregues pelos contribuintes, como, por exemplo, em relação aos incentivos relacionados com o Imposto de sobre Produto Industrializado - IPI, já que a respectiva declaração (Declaração do Imposto sobre Produtos Industrializados - DIPI) carece de informações detalhadas e específicas sobre as diversas modalidades de benefícios (dedução, isenção, redução de base de cálculo, etc) que foram utilizadas pelos contribuintes.

\footnotetext{
${ }^{208}$ Evidenciação das renúncias de receitas tributárias federais pela Contabilidade Pública: importância e dificuldades. Por Júlio César Azevedo Teixeira. Brasília, DF. 2006 in.

http://portal2.tcu.gov.br/portal/pls/portal/docs/2055712.PDF. Acesso em 30/07/12
} 
Desse modo, no caso, por exemplo, das deduções do Imposto de Renda Pessoa Física - IRPF e do Imposto de Renda da Pessoa Jurídica - IRPJ, aplicadas em programas de apoio à cultura, ou a atividades audiovisuais, utiliza-se, como fonte de dados para o cálculo da estimativa dessa renúncia, as respectivas declarações dos impostos entregues pelos contribuintes, no exercício seguinte ao dos fatos geradores, bem como, também, as informações encaminhadas pelo Ministério da Cultura a respeito da expectativa de utilização dos referidos benefícios culturais. Assim, levando-se em conta que boa parte dos dados sobre as renúncias tributárias são extraídas das declarações de impostos, entregues pelos contribuintes no exercício posterior ao gozo desses benefícios, e sendo que o processamento final dessas declarações, pela SRF, somente ocorre no ano seguinte ao da entrega, pode-se afirmar que, atualmente, a mensuração de importante parcela dos respectivos valores efetivamente renunciados somente ocorre cerca de dois anos após a ocorrência do fato gerador.

Além da intempestividade da informação, outro obstáculo para a evidenciação dessas renúncias diz respeito à falta de confiabilidade das mencionadas fontes de dados utilizadas para o cálculo dos respectivos valores, tendo em vista que as informações são oriundas das declarações prestadas pelos próprios contribuintes dos referidos benefícios, sem que haja, atualmente, qualquer sistema de informação, no âmbito da arrecadação tributária, capaz de verificar a correção dessas informações.

Não só há o questionamento a respeito da qualidade da informação, mas surge, também, a discussão sobre a natureza contábil da renúncia de receita. Embora a Secretaria do Tesouro Nacional tenha normatizado seu registro usando a metodologia da dedução de receita, entende-se que, considerando que essas renúncias apresentam características similares, em termos econômicos, aos gastos ou dispêndios aplicados em programas e políticas governamentais, resta a dúvida relacionada com a forma de evidenciação dos seus valores, bem como seu enquadramento no âmbito dos respectivos sistemas: financeiro, orçamentário, patrimonial e de compensação.

Em relação à natureza e a forma de evidenciação dessas renúncias, pode-se dizer que a questão guarda relação fundamental, tanto com o previsto no art. $165, \S 6^{\circ}$ da Constituição Federal, quanto com os dispositivos da LRF (art. $1^{\circ}, \S 1^{\circ}$ e art. 14), e que, 
destacam a importância do controle e da transparência das renúncias para as finanças públicas, notadamente quanto aos seus efeitos sobre as receitas e despesas orçamentárias.

Portanto, tendo em vista que a Secretaria da Receita Federal, órgão responsável pela previsão da maior parte dos benefícios tributários, não dispõe de informações confiáveis e tempestivas acerca dos respectivos valores renunciados, fica evidente que a Contabilidade Pública do Governo Federal se depara, atualmente, com obstáculos que, praticamente, impedem o registro de tais montantes.

Neste sentido, o controle se mostra dificultoso, seja em quaisquer de seus aspectos (interno ou externo), até porque a principal legislação de regência da Contabilidade Pública, ou seja, a Lei nº 4.320/1964, é bem anterior à promulgação da Carta Magna de 1988, e se não acontecer a correta visão do tema na Lei de Responsabilidade Fiscal, fica patente a existência de lacuna legal a respeito da natureza, o registro e a evidenciação dessas renúncias no âmbito da contabilidade governamental.

Particularmente o tema envolve o patrimônio público muito mais no aspecto financeiro (portanto, entendido latu sensu) e menos no patrimonial sob a ótica específica de bens corpóreos.

Assim, analisado o art. 70 da Constituição Federal, passa-se ao estudo do Ministério Público e do Tribunal de Contas diante de sua importância em fazer valer, na prática, aquele comando constitucional. 


\section{CAPÍTULO 4 - TRIBUNAL DE CONTAS E MINISTÉRIO PÚBLICO}

Tendo em vista a importância da atuação tanto dos Tribunais de Contas como do Ministério Público no tema da fiscalização patrimonial da administração pública, se faz necessário um Capítulo específico para abordar cada um deles e como se inserem no cenário brasileiro.

\section{1 - O Tribunal de Contas}

\subsection{1 - Histórico.}

As primeiras notícias sobre controle de contas públicas no Brasil datam de 1680 com a criação das Juntas das Fazendas das Capitanias e da Junta da Fazenda do Rio de Janeiro ${ }^{209}$, todas ligadas a Portugal, sendo que o controle deveria se dar nos mesmos moldes que naquele país, até porque, como colônia, o Brasil adotava as leis de Portugal.

O Conselho de Contas criado pelo então Príncipe Regente (futuro D. João VI) por meio do Alvará de 28 de junho de $1808^{210}$ trazia a ideia do Tribunal de Contas, com a criação do Conselho da Fazenda para fiscalizar o cumprimento dos princípios da legalidade e da regularidade. Válido para a Metrópole, também servia à Colônia.

Com a Constituição Política do Império do Brasil, de março de 1824, já proclamada a independência por D. Pedro I, constou previsão no art. 170 do "Thesouro Nacional", um Tribunal com função de verificar a administração, arrecadação e contabilidade da receita e da despesa da Fazenda Nacional. Pelo art. 172 o Ministro de Estado da Fazenda deveria receber das outras pastas os orçamentos relativos às suas despesas e apresentá-los à Câmara dos Deputados por meio de um balanço geral. Ao mesmo tempo apresentar o orçamento geral de todas as despesas públicas do ano seguinte e ainda a importância de todas as contribuições e rendas públicas a ela relativas ${ }^{211}$.

\footnotetext{
${ }^{209}$ CASTARDO, Hamilton Fernando. O Tribunal de Contas no ordenamento jurídico brasileiro. Campinas: Milenum, 2007. P.37

210 FRANÇA, Rubens Limongi (Org.). Enciclopédia Saraiva de Direito. São Paulo: Saraiva, 1977, p.86

211 CAPITULO III - Da Fazenda Nacional. Art. 170. A Receita, e despeza da Fazenda Nacional será encarregada a um Tribunal, debaixo de nome e "Thesouro Nacional" aonde em diversas Estações, devidamente estabelecidas por Lei, se regulará a sua administração, arrecadação e contabilidade, em reciproca correspondencia com as Thesourarias, e Autoridades das Provincias do Imperio.
} 
Para Artur Cotias ${ }^{212}$ apesar do exame previsto naquela Constituição não se revestir do caráter de julgamento de gestão, prestando-se somente a oferecer um quadro comparativo da receita e da despesa, a instituição daquele Tribunal viria a ser, de fato, uma espécie de ponto de partida para a criação do Tribunal de Contas.

Anota que já em 1826 houve por parte do Visconde de Barbacena a apresentação ao Senado de um projeto de lei criando um Tribunal de Revisão de Contas e em 4 de outubro de 1831 foi sancionada a Lei n 657 aprovando a criação do Tribunal do Tesouro Público Nacional em substituição ao Erário. A ele incumbiria o levantamento e o julgamento das contas dos responsáveis por dinheiro público, dentro ou fora do país, porém sem autonomia para desempenho das funções. Esta proposta fora rejeitada frente à discussão quanto à necessidade de um órgão independente para exame das contas públicas ou a continuação do controle pelos mesmos órgãos que as realizavam ${ }^{213}$.

Após a proclamação da República surge uma Corte nos moldes da atual, com a criação do Tribunal de Contas da União pelo Decreto $n^{\circ} 966-\mathrm{A}$ de 07 de novembro de 1890 instituído pelo Marechal Deodoro da Fonseca, então "Chefe do Governo Provisório da República dos Estados Unidos do Brazil”, por iniciativa de Rui Barbosa, Ministro da Fazenda, Tribunal este que recebeu 'status' constitucional em 1891. Entretanto, somente foi instalado em definitivo em 17 de janeiro de 1893, por esforço do então Ministro da Fazenda do governo de Floriano Peixoto, o Tenente-Coronel Innocêncio Serzedello Corrêa ${ }^{214}$.

Art. 171. Todas as contribuições directas, á excepção daquellas, que estiverem applicadas aos juros, e amortisação da Divida Publica, serão annualmente estabelecidas pela Assembléa Geral, mas continuarão, até que se publique a sua derogação, ou sejam substituidas por outras.

Art. 172. O Ministro de Estado da Fazenda, havendo recebido dos outros Ministros os orçamentos relativos ás despezas das suas Repartições, apresentará na Camara dos Deputados annualmente, logo que esta estiver reunida, um Balanço geral da receita e despeza do Thesouro Nacional do anno antecedente, e igualmente o orçamento geral de todas as despezas publicas do anno futuro, e da importancia de todas as contribuições, e rendas publicas.

http://www.planalto.gov.br/ccivil 03/Constituicao/Constituicao24.htm - acesso em 16/03/2011

${ }^{212}$ SILVA, Artur Adolfo Cotias e. Tribunal de Contas da União na histórica do Brasil. Evolução histórica, política e adminstrativa (1890-1998). in Brasil. Tribunal de Contas da União. Prêmio Serzedello Corrêa 1998

- Monografias Vencedoras - $1^{\text {o }}$ lugar. Brasilia: TCU, Instituo Serzedello Corrêa, 1999, p.14. apud CASTARDO, Hamilton Fernando. O Tribunal de Contas no ordenamento jurídico brasileiro. Campinas: Milenum, 2007, p.38

213 MILESKI, Helio Saul. O Controle da Gestão Pública. São Paulo: RT. 2003, p.191.

${ }^{214}$ CASTARDO, Hamilton Fernando. O Tribunal de Contas no ordenamento jurídico brasileiro. Campinas: Milenum, 2007, p.42 
4.1.2 - O Tribunal de Contas e o perfil atual.

\subsubsection{1 - Composição.}

Hoje o Tribunal de Contas tem sua disciplina nos artigos 71 e seguintes da Constituição Federal constituindo-se em órgão auxiliar do Congresso Nacional, que detém incumbência do controle externo para efeito de fiscalização contábil, financeira, orçamentária, operacional e patrimonial da União e das entidades da administração direta e indireta, quanto à legalidade, legitimidade, economicidade, aplicação das subvenções e renúncia de receitas, conforme o artigo 70 da $\mathrm{CF}$.

O Tribunal de Contas da União é integrado por nove Ministros nomeados dentre brasileiros que satisfaçam os requisitos de ter mais de trinta e cinco e menos de sessenta e cinco anos de idade; idoneidade moral e reputação ilibada; notórios conhecimentos jurídicos, contábeis, econômicos e financeiros ou de administração pública e mais de dez anos de exercício de função ou de efetiva atividade profissional que exija aqueles conhecimentos. Tem sede no Distrito Federal, quadro próprio de pessoal e jurisdição em todo o território nacional.

Os Ministros do Tribunal de Contas da União são escolhidos um terço pelo Presidente da República, com aprovação do Senado Federal, sendo dois alternadamente dentre auditores e membros do Ministério Público junto ao Tribunal, indicados em lista tríplice pelo Tribunal, segundo os critérios de antigüidade e merecimento e dois terços pelo Congresso Nacional ${ }^{215}$.

\footnotetext{
215 Decisão proferida pelo STF em 02/12/2004 na ADI no 2884 do Rio de Janeiro em ação direta de inconstitucionalidade de relatoria do Min. Celso de Mello 02/12/2004 e publicada no DJ de 20/05/2005, p.00005 indica que "Os Tribunais de Contas estaduais deverão ter quatro Conselheiros eleitos pela Assembléia Legislativa e três outros nomeados pelo Chefe do Poder Executivo do Estado-membro. Dentre os três Conselheiros nomeados pelo Chefe do Poder Executivo estadual, apenas um será de livre nomeação do Governador do Estado. Os outros dois deverão ser nomeados pelo Chefe do Poder Executivo local, necessariamente, dentre ocupantes de cargos de Auditor do Tribunal de Contas (um) e de membro do Ministério Público junto à Corte de Contas local (um). Súmula 653/STF. - Uma das nomeações para os Tribunais de Contas estaduais, de competência privativa do Governador do Estado, acha-se constitucionalmente vinculada a membro do Ministério Público especial, com atuação perante as próprias Cortes de Contas. O Ministério Público Especial junto aos Tribunais de Contas não se confunde com os demais ramos do Ministério Público comum da União e dos Estados membros - O Ministério Público especial junto aos Tribunais de Contas - que configura uma indiscutível realidade constitucional - qualificase como órgão estatal dotado de identidade e de fisionomia próprias que o tornam inconfundível e inassimilável à instituição do Ministério Público comum da União e dos Estados-membros.- Não se reveste de legitimidade constitucional a participação do Ministério Público comum perante os Tribunais de Contas
} 
Assim também, as normas estabelecidas nos artigos 71 a 74 da Constituição Federal se aplicam, no que couberem, à organização, composição e fiscalização dos Tribunais de Contas dos Estados e do Distrito Federal, bem como dos Tribunais e Conselhos de Contas dos Municípios, sendo que as respectivas Constituições estaduais disporão sobre os Tribunais de Contas Estaduais, que serão integrados por sete Conselheiros.

\subsubsection{2 - Atribuições e Jurisdição.}

No rol de atribuições constitucionais, consta que compete ao Tribunal de Contas apreciar as contas prestadas anualmente pelo Presidente da República, mediante parecer prévio que deverá ser elaborado em sessenta dias a contar de seu recebimento; julgar as contas dos administradores e demais responsáveis por dinheiros, bens e valores públicos da administração direta e indireta, incluídas as fundações e sociedades instituídas e mantidas pelo Poder Público federal, e as contas daqueles que derem causa a perda, extravio ou outra irregularidade de que resulte prejuízo ao erário público; apreciar, para fins de registro, a legalidade dos atos de admissão de pessoal, a qualquer título, na administração direta e indireta, incluídas as fundações instituídas e mantidas pelo Poder Público, excetuadas as nomeações para cargo de provimento em comissão, bem como a das concessões de aposentadorias, reformas e pensões, ressalvadas as melhorias posteriores que não alterem o fundamento legal do ato concessório; realizar, por iniciativa própria, da Câmara dos Deputados, do Senado Federal, de Comissão técnica ou de inquérito, inspeções e auditorias de natureza contábil, financeira, orçamentária, operacional e patrimonial, nas unidades administrativas dos Poderes Legislativo, Executivo e Judiciário, e demais entidades da administração direta e indireta, incluídas as fundações e sociedades instituídas e mantidas pelo Poder Público.

dos Estados, pois essa participação e atuação acham-se constitucionalmente reservadas aos membros integrantes do Ministério Público especial, a que se refere a própria Lei Fundamental da República (art. 130). - O preceito consubstanciado no art. 130 da Constituição reflete uma solução de compromisso adotada pelo legislador constituinte brasileiro, que preferiu não outorgar, ao Ministério Público comum, as funções de atuação perante os Tribunais de Contas, optando, ao contrário, por atribuir esse relevante encargo a agentes estatais qualificados, deferindo-lhes um "status" jurídico especial e ensejando-lhes, com o reconhecimento das já mencionadas garantias de ordem subjetiva, a possibilidade de atuação funcional exclusiva e independente perante as Cortes de Contas. 
Também que deverá fiscalizar as contas nacionais das empresas supranacionais de cujo capital social a União participe, de forma direta ou indireta, nos termos do tratado constitutivo; fiscalizar a aplicação de quaisquer recursos repassados pela União mediante convênio, acordo, ajuste ou outros instrumentos congêneres, a Estado, ao Distrito Federal ou a Município; prestar as informações solicitadas pelo Congresso Nacional, por qualquer de suas Casas, ou por qualquer das respectivas Comissões, sobre a fiscalização contábil, financeira, orçamentária, operacional e patrimonial e sobre resultados de auditorias e inspeções realizadas; aplicar aos responsáveis, em caso de ilegalidade de despesa ou irregularidade de contas, as sanções previstas em lei, que estabelecerá, entre outras cominações, multa proporcional ao dano causado ao erário; assinar prazo para que o órgão ou entidade adote as providências necessárias ao exato cumprimento da lei, se verificada ilegalidade; sustar, se não atendido, a execução do ato impugnado, comunicando a decisão à Câmara dos Deputados e ao Senado Federal e representar ao Poder competente sobre irregularidades ou abusos apurados.

Especificamente, o Tribunal de Contas da União (TCU), tem sua Lei Orgânica na Lei $n^{\circ} 8.443$ de 16 de julho de 1992 e diversas são as competências nela estabelecidas:

Assim, indica que deverá o TCU julgar as contas dos administradores e demais responsáveis por dinheiros, bens e valores públicos das unidades dos poderes da União e das entidades da administração indireta, incluídas as fundações e sociedades instituídas e mantidas pelo poder público federal, e as contas daqueles que derem causa a perda, extravio ou outra irregularidade de que resulte dano ao Erário; proceder, por iniciativa própria ou por solicitação do Congresso Nacional, de suas Casas ou das respectivas comissões, à fiscalização contábil, financeira, orçamentária, operacional e patrimonial das unidades dos poderes da União e outras entidades similares e ainda apreciar as contas prestadas anualmente pelo Presidente da República, nos termos do art. $36^{216}$.

\footnotetext{
${ }^{216}$ Art. 36. Ao Tribunal de Contas da União compete, na forma estabelecida no regimento interno, apreciar as contas prestadas anualmente pelo Presidente da República, mediante parecer prévio a ser elaborado em sessenta dias a contar de seu recebimento. Parágrafo único. As contas consistirão nos balanços gerais da União e no relatório do órgão central do sistema de controle interno do Poder Executivo sobre a execução dos orçamentos de que trata o $\S 5^{\circ}$ do art. 165 da Constituição Federal.
} 
Também deverá acompanhar a arrecadação da receita a cargo da União e das entidades da administração indireta, incluídas as fundações e sociedades instituídas e mantidas pelo poder público federal, mediante inspeções e auditorias, ou por meio de demonstrativos próprios, na forma estabelecida no Regimento Interno; apreciar, para fins de registro, na forma estabelecida no Regimento Interno, a legalidade dos atos de admissão de pessoal, a qualquer título, na administração direta e indireta, incluídas as fundações instituídas e mantidas pelo poder público federal, excetuadas as nomeações para cargo de provimento em comissão, bem como a das concessões de aposentadorias, reformas e pensões, ressalvadas as melhorias posteriores que não alterem o fundamento legal do ato concessório; efetuar, observada a legislação pertinente, o cálculo das quotas referentes aos fundos de participação (parcela do tributo da união repassado aos municípios), fiscalizando a entrega dos respectivos recursos.

E ainda emitir, nos termos do $\S 2^{\circ}$ do art. 33 da Constituição Federal ${ }^{217}$, parecer prévio sobre as contas do Governo de Território Federal, no prazo de sessenta dias, a contar de seu recebimento, na forma estabelecida no Regimento Interno; representar ao poder competente sobre irregularidades ou abusos apurados, indicando o ato inquinado e definindo responsabilidades, inclusive as de Ministro de Estado ou autoridade de nível hierárquico equivalente; aplicar aos responsáveis as sanções previstas nos arts. 57 a 61, que variam desde multas até inabilitação para exercício de cargo em comissão ou função de confiança no âmbito da administração pública ou mesmo medidas necessárias ao arresto dos bens dos responsáveis julgados em débito, devendo ser ouvido quanto à liberação dos bens arrestados e sua restituição (neste caso com participação do Ministério Público ou Advocacia Geral da União).

Também deve o TCU, na ordem de sua própria administração, elaborar e alterar seu Regimento Interno; eleger seu Presidente e seu Vice-Presidente, e dar-lhes posse; conceder licença, férias e outros afastamentos aos ministros, auditores e membros do Ministério Público junto ao Tribunal, dependendo de inspeção por junta médica a licença para tratamento de saúde por prazo superior a seis meses; propor ao Congresso Nacional a fixação de vencimentos dos ministros, auditores e membros do Ministério

${ }^{217}$ Art. 33, § $2^{\circ}$ - As contas do Governo do Território serão submetidas ao Congresso Nacional, com parecer prévio do Tribunal de Contas da União. 
Público junto ao Tribunal; organizar sua Secretaria, na forma estabelecida no Regimento Interno, e prover-lhe os cargos e empregos, observada a legislação pertinente; propor ao Congresso Nacional a criação, transformação e extinção de cargos, empregos e funções de quadro de pessoal de sua secretaria, bem como a fixação da respectiva remuneração. Aqui é perceptível o aspecto da independência funcional da Corte de Contas.

E decidir sobre denúncia que lhe seja encaminhada por qualquer cidadão, partido político, associação ou sindicato; decidir sobre consulta que lhe seja formulada por autoridade competente, a respeito de dúvida suscitada na aplicação de dispositivos legais e regulamentares concernentes a matéria de sua competência, na forma estabelecida no Regimento Interno e também quando do julgamento de contas e na fiscalização que lhe compete, decidir sobre a legalidade, a legitimidade e a economicidade dos atos de gestão e das despesas deles decorrentes, bem como sobre a aplicação de subvenções e a renúncia de receitas.

Ainda lhe assiste, no âmbito de sua competência e jurisdição, o poder regulamentar, podendo, em consequência, expedir atos e instruções normativas sobre matéria de suas atribuições e sobre a organização dos processos que lhe devam ser submetidos, obrigando ao seu cumprimento, sob pena de responsabilidade.

O Tribunal tem jurisdição própria e privativa, em todo o território nacional, sobre as pessoas e matéria sujeitas à sua competência.

A jurisdição abrange qualquer pessoa física, órgão ou entidade que utilize, arrecade, guarde, gerencie ou administre dinheiros, bens e valores públicos ou pelos quais a União responda, ou que, em nome desta assuma obrigações de natureza pecuniária das entidades da administração indireta, incluídas as fundações e sociedades instituídas e mantidas pelo poder público federal, e as contas daqueles que derem causa a perda, extravio ou outra irregularidade de que resulte dano ao erário; os dirigentes ou liquidantes das empresas encampadas ou sob intervenção ou que de qualquer modo venham a integrar, provisória ou permanentemente, o patrimônio da União ou de outra entidade pública federal; os responsáveis pelas contas nacionais das empresas supranacionais de cujo capital social a União participe, de forma direta ou indireta, nos termos do tratado constitutivo. 
Também os responsáveis por entidades dotadas de personalidade jurídica de direito privado que recebam contribuições parafiscais e prestem serviço de interesse público ou social; todos aqueles que lhe devam prestar contas ou cujos atos estejam sujeitos à sua fiscalização por expressa disposição de Lei; os responsáveis pela aplicação de quaisquer recursos repassados pela União, mediante convênio, acordo, ajuste ou outros instrumentos congêneres, a Estado, ao Distrito Federal ou a Município; os sucessores dos administradores e responsáveis das entidades já mencionadas, até o limite do valor do patrimônio transferido, nos termos do inciso XLV do art. $5^{\circ}$ da Constituição Federal ${ }^{218}$; e os representantes da União ou do Poder Público na assembleia geral das empresas estatais e sociedades anônimas de cujo capital a União ou o Poder Público participem, solidariamente, com os membros dos conselhos fiscal e de administração, pela prática de atos de gestão ruinosa ou liberalidade à custa das respectivas sociedades.

Exemplo de atividade do TCU diante da fiscalização e gestão do patrimônio público encontra-se nos autos do TC- 012.491/2004-4 ${ }^{219}$ quando analisou patrimônio do INSS (Instituto Nacional do Seguro Social), diante de consulta efetuada pelo Ministro da Previdência Social.

Pelo primeiro questionamento, foi verificado se a interpretação da Lei $\mathrm{n}^{\circ}$ 9.702/98 seria no sentido da exigência de que o INSS deveria alienar seus imóveis não operacionais. Entendeu o TCU que a mencionada Lei efetivamente pretendeu proporcionar os meios legais para que as alienações pudessem ser levadas a termo. O vocábulo “autorização" constante no art. $1^{\circ}$ (cuja natureza é de poder-dever) teria por objetivo atender as disposições do art. 17, I da Lei de Licitações (Lei $\mathrm{n}^{\circ}$ 8.666/93) que indica que a alienação de bens públicos imóveis dependerá de "autorização legislativa".

A Lei $n^{\circ}$ 9.702/98 derivou de medida provisória cuja exposição de motivos reforça a percepção de que o objetivo da norma foi compelir o INSS a alienar seus imóveis não operacionais fornecendo os instrumentos legais para tanto. Concluiu-se que com a venda, o custo operacional do Instituto seria reduzido, com economia de tempo e recursos da administração em sua manutenção, bem como direcionamento de tal energia para sua

\footnotetext{
${ }^{218}$ Art. 5 ${ }^{\circ}$. XLV - nenhuma pena passará da pessoa do condenado, podendo a obrigação de reparar o dano e a decretação do perdimento de bens ser, nos termos da lei, estendidas aos sucessores e contra eles executadas, até o limite do valor do patrimônio transferido

${ }^{219}$ AGUIAR, Ubiratan. Controle Externo. Belo Horizonte: Ed. Forum, 2006. p. 144-156
} 
finalidade primordial com acréscimo de receitas. Na referida exposição de motivos há indicação de que o INSS teria cerca de seis mil imóveis que deveriam ser alienados, mesmo diante de condições restritivas tais como a inexistência de instrumentos legais para amparar a venda em condições específicas dos imóveis residenciais situados em áreas destinadas a assentamentos de famílias de baixa renda; à restrição legal que condiciona a venda direta de imóveis aos então ocupantes à existência de licitação prévia e à ausência de dispositivo legal que favorecesse a aquisição dos imóveis ocupados por órgãos e entidades públicas em geral.

Entretanto, ciente das dificuldades, admitiu-se, em casos excepcionais (como por exemplo na ausência de interessados quando de licitação aberta para venda de um determinado imóvel) a locação como alternativa, posto que a tal medida implicaria em permitir renda para a entidade, atendendo melhor o interesse público do que deixá-lo vago com riscos de invasão e despesas de vigilância. Para tanto, seria exigível do gestor a demonstração de que envidou esforços para a alienação antes de optar pela alternativa. Também indicou a Corte de Contas que a opção pelo aluguel não poderia ser definitiva, sendo cabível a análise periódica da situação do mercado para viabilizar a venda oportunamente.

Para os contratos de locação vigentes à época da consulta (2004) o TCU decidiu que os prazos estabelecidos no art. 57 da Lei $n^{\circ} 8.666 / 93$ não seriam aplicados a eles por força do disposto no art. $62, \S 2^{\circ}$ da mesma lei, admitindo-se a cobrança de taxa de ocupação sem contrato, como medida de caráter temporário, até a conclusão dos procedimentos de venda do imóvel, quando então o ocupante teria o direito de preferência para adquirí-lo pelo preço mínimo, conforme arts. $2^{\circ}$ e $3^{\circ}$ da Lei $n^{\circ} 9.702 / 98$, ou de desocupação se não tivesse o direito de preferência ou não desejasse exercê-lo, conforme arts. $2^{\circ}$ e $7^{\circ}$ da Lei $n^{\circ} 9.702 / 98$, ou mesmo até o encerramento de eventuais demandas judiciais que discutissem a posse do imóvel.

O voto do relator indicou, para justificar a medida, que os imóveis do INSS possuem característica específica que os diferencia dos imóveis da União, por exemplo. Os imóveis dominicais do INSS fariam parte do Fundo do Regime Geral de Previdência Social, criado com a finalidade de assegurar o pagamento dos benefícios previdenciários. 
Seguindo o questionamento da parte que efetuou a consulta, foi analisada a locação de imóveis vagos ou invadidos e tanto para os operacionais como para os não operacionais.

Assim, para os operacionais, não passíveis de alienação (os que constituem a chamada reserva técnica e os pendentes de regularização) seria possível a locação nos termos de previsão do art. 11 da Lei n ${ }^{\circ}$ 9.702/98 com os então ocupantes. Quanto aos vagos também não se vislumbrou óbice para a locação, até porque se vedada a alienação e não tendo utilidade, não faria sentido mantê-los gerando despesas e sem auferir receitas (além do risco de invasão). Para os não operacionais adotou-se a mesma conclusão do primeiro ítem analisado (medida excepcional).

Discutiu-se o significado do termo "atuais ocupantes" se seriam aqueles à época da edição da Lei (1998) ou da regularização da situação (2004). O relator discordando da Unidade Técnica do Tribunal e do Ministério Público do TCU, apontou que a expressão deveria se referir aos ocupantes ao tempo da regularização e sustentou sua tese lembrando que o escopo da Lei $n^{\circ}$ 9.702/98 foi de permitir alienação de imóveis do INSS e também permitir que o instituto regularizasse sua situação patrimonial (tanto que permitiu que se regularizasse posse de imóveis não passíveis de alienação, mediante celebração de contratos de locação).

Assim, era de se esperar que em seguida à edição de Lei o INSS identificasse os imóveis que se enquadravam naquela situação e buscasse resolver os problemas de imediato (locando-os ou desocupando-os). Como, decorridos seis anos da lei até a consulta, o próprio INSS admitiu a existência de imóveis ocupados, interpretar que 'atuais ocupantes' seriam aqueles à época da Lei dificultaria ainda mais a regularização seja porque deveria ser pesquisado se tal ocupação acontecera antes ou depois da edição da lei, seja porque se demonstrado que foi depois, a desocupação seria exigida (processo complicado e demorado). Portanto, mesmo diante da inércia do Instituto, a indicação foi de que deveriam ser considerados 'atuais ocupantes' aqueles ao tempo da regularização da situação.

Por último foi indagado do Tribunal se o INSS poderia locar seus imóveis operacionais a órgãos públicos sem licitação e a resposta foi positiva. O argumento foi de 
que o art. 17 da Lei $\mathrm{n}^{\circ}$ 8.666/93 dispõe que a alienação de bens imóveis deve ser precedida de licitação, dispensada esta no caso de venda ou de doação a qualquer órgão ou entidade da Administração Pública, de qualquer esfera de governo e a não ser que a lei vedasse expressamente, não seria razoável entender que medidas destinadas à transferência da propriedade do bem fossem autorizadas sem licitação e a locação, que envolve apenas a transferência temporária da posse não fosse permitida. Portanto, apesar de inexistir expressa disposição na Lei de Licitações a respeito, o TCU considerou possível ao INSS locar imóvel a orgãos e entidades da Administração Pública sem licitação.

Observa-se do caso mencionado a manifestação direta do Tribunal de Contas por provocação, na modalidade consulta, no sentido de fixar diretrizes específicas no cuidado com o patrimônio físico, no que concerne aos bens imóveis do INSS, valendose de critérios de legalidade e economicidade e ainda no exercício do controle preventivo e concomitante, inclusive apresentando interpretações para lacunas da lei.

Por outro lado, de nada vale fiscalizar e verificar irregularidades ou incongruências se não for possível aplicar sanção.

Assim como a verificação de um ato de improbidade administrativa pode levar à propositura de ação civil correspondente com aplicação de pena por meio do Poder Judiciário ao administrador público reconhecido como ímprobo - e aqui se referem penas de alta gravidade, como até mesmo perda do cargo - há que se aceitar que as Cortes de Contas também detenham poder sancionatório ${ }^{220}$.

\subsubsection{3 - Poder Sancionatório.}

Para que bem realize o controle das contas públicas, valendo-se da fiscalização contábil, financeira, orçamentária, operacional e patrimonial o Tribunal de Contas pode penalizar o administrador público.

\footnotetext{
220 "Não é possível, efetivamente, entender que as decisões das Cortes de Contas, no exercício de sua competência constitucional, não possuam teor de coercibilidade. Possibilidade de impor sanções, assim como a lei disciplinar. Certo está que, na hipótese de abuso no exercício dessas atribuições por agentes da fiscalização dos tribunais de contas, ou de desvio de poder, os sujeitos passivos das sanções impostas possuem os meios que a ordem jurídica contém para o controle de legalidade dos atos de quem quer que exerça parcela de autoridade ou poder, garantidos, a tanto, ampla defesa e o devido processo legal." (RE 190.985, Rel. Min. Néri da Silveira, julgamento em 14-2-1996, Plenário, DJ de 24-8-2001.)
} 
Uma primeira sanção seria a multa ${ }^{221}$. Três as espécies: proporcional ao dano causado ao erário; diante de infração administrativa contra as leis de finanças públicas e por infração às normas de administração financeira e orçamentária.

A multa por dano ao erário está prevista no art. 71, VIII da Constituição. Considera-se que a norma é de eficácia contida, em face de exigência de lei para sua aplicabilidade e exige a caracterização efetiva do dano ao erário (posto que a multa deve ser proporcional ao valor do dano). Vale consignar que dano ao erário é aquele de natureza financeira ou patrimonial, diferentemente do dano à administração cuja lesão é de caráter genérico.

Para a União há previsão na Lei no 8.443 de 16/07/1992 (Lei Orgânica do TCU) sobre aplicação de multa de até $100 \%$ do valor do dano.

A multa por infração administrativa contra as leis de finanças públicas (Lei 10.028/2000, que alterou o Código Penal, a Lei no 1079/1950 e o Decreto-Lei nº 201/1967, estabelecendo penalidades de natureza criminal e administrativa para os gestores fiscais que violassem normas de direito financeiro contidas na Lei Complementar $n^{\circ}$ 101/2000 LRF) é da ordem de $30 \%$ dos vencimentos anuais do agente que der causa à irregularidade. A infração é processada e julgada no âmbito do Tribunal de Contas a quem competir a fiscalização.

As irregularidades estão previstas no art. $5^{\circ}$ da Lei $n^{\circ} 10.028 / 2000$, que indica constituir infração administrativa contra as leis de finanças públicas: a) deixar de divulgar ou de enviar ao Poder Legislativo e ao Tribunal de Contas o relatório de gestão fiscal, nos prazos e condições estabelecidos em lei; b) propor lei de diretrizes orçamentárias anual que não contenha as metas fiscais na forma da lei; c) deixar de expedir ato determinando limitação de empenho e movimentação financeira, nos casos e condições estabelecidos em lei e d) deixar de ordenar ou de promover, na forma e nos prazos da lei, a execução de medida para a redução do montante da despesa total com pessoal que houver excedido a repartição por Poder do limite máximo.

${ }^{221}$ A jurisprudência do Tribunal de Contas da União indica que a natureza da multa, em quaisquer de suas espécies é eminentemente punitiva, e, portanto, não pode passar da pessoa do agente, conforme Acórdão TCU no 92/1999, 2ª Câmara e Acórdão TCU no 293/1998, 2ª Câmara. 
A terceira modalidade - sobre multas por infração às normas de administração financeira e orçamentária - conforme art. 71, VIII da CF deve estar prevista em lei e possui objetivo de penalizar o administrador pela prática de ato que, embora não seja danoso ao erário, posto que se revista de natureza de falha formal, demonstre procedimento violador das normas da administração financeira e orçamentária, e por consequência, patrimonial.

O prejuízo, na verdade, é ao regular andamento da administração financeira e patrimonial ou ao exercício do controle externo. Visa evitar que as falhas continuem a ocorrer.

Outra natureza de sanção é a glosa da despesa, mediante impugnação dos valores apurados, com fixação do débito ao responsável, a fim de que promova a devolução dos valores glosados, em recomposição ao prejuízo que causou.

Decorre de auditoria ou julgamento de contas que tenha constatado prática de ato que resultou em utilização indevida de bens e equipamentos ou ilegalidade de despesas.

A Lei Orgânica do Tribunal de Contas da União prevê no art. 19 que quando julgar as contas irregulares, havendo débito, o Tribunal condenará o responsável ao pagamento da dívida atualizada monetariamente, acrescida dos juros de mora devidos, podendo, ainda, aplicar-lhe a multa (prevista no art. 57 da mesma lei), sendo o instrumento da decisão considerado título executivo para fundamentar a respectiva ação de execução.

E também que não havendo débito, mas comprovada qualquer das ocorrências previstas nas alíneas a, b e c do inciso III, do art. 16, o Tribunal aplicará ao responsável a multa prevista no inciso I do art. 58 (revalorada pela Portaria no 34/2012 do TCU $)^{222}$.

\footnotetext{
${ }^{222}$ Art. 58. O Tribunal poderá aplicar multa de Cr\$ 42.000.000,00 (quarenta e dois milhões de cruzeiros), ou valor equivalente em outra moeda que venha a ser adotada como moeda nacional, aos responsáveis por: I contas julgadas irregulares de que não resulte débito, nos termos do parágrafo único do art. 19 desta Lei; II ato praticado com grave infração à norma legal ou regulamentar de natureza contábil, financeira, orçamentária, operacional e patrimonial; III - ato de gestão ilegítimo ou antieconômico de que resulte
} 
Sempre lembrando que nos Estados, no Distrito Federal e nas Cidades de São Paulo e Rio de Janeiro (onde há Tribunais de Contas, alguns específicos), providências semelhantes podem ser adotadas, consoante a legislação local autorizar.

Ainda como sanção existe a possibilidade de fixação de prazo para adoção de providências e sustação de ato impugnado.

Nas ocasiões em que verificada irregularidade, o Tribunal deverá fixar um prazo para que o administrador ou o órgão ou a entidade fiscalizada adotem providências necessárias ao cumprimento da lei. Tanto quando de auditoria ou emissão de parecer prévio, de julgamento de contas ou apreciação de legalidade que enseje sustação ou modificação do ato, mesmo que resulte em decisão que fixe débito e aplique multa, o Tribunal deverá assinalar prazo para que providências sejam adotadas visando restabelecer a legalidade rompida.

Na hipótese da não adoção das providências, o Tribunal de Contas deverá comunicar a decisão de que sustou o ato (caso de admissão, aposentadoria, reforma, pensões) ao Poder Legislativo (art. 71, X - CF), ou ainda comunicar outros órgãos como Procuradorias Estaduais e Municipais ou Ministério Público, quando verificar ocorrência de crime, ato de improbidade administrativa ou que multa não paga detém caráter de título executivo (art. $71 \S 3^{\circ} \mathrm{da} \mathrm{CF}$ ).

Aliás, a providência de comunicar ao Ministério Público encontra-se no art. $18, \S 2^{\circ}$ da Lei $n^{\circ} 8.443 / 92$, sendo que ao parquet incumbirá investigar e propor ação civil

injustificado dano ao Erário; IV - não atendimento, no prazo fixado, sem causa justificada, a diligência do Relator ou a decisão do Tribunal; V - obstrução ao livre exercício das inspeções e auditorias determinadas; VI - sonegação de processo, documento ou informação, em inspeções ou auditorias realizadas pelo Tribunal; VII - reincidência no descumprimento de determinação do Tribunal. $\S 1^{\circ}$ Ficará sujeito à multa prevista no caput deste artigo aquele que deixar de dar cumprimento à decisão do Tribunal, salvo motivo justificado. $\S 2^{\circ}$ O valor estabelecido no caput deste artigo será atualizado, periodicamente, por portaria da Presidência do Tribunal, com base na variação acumulada, no período, pelo índice utilizado para atualização dos créditos tributários da União. $\S 3^{\circ} \mathrm{O}$ Regimento Interno disporá sobre a gradação da multa prevista no caput deste artigo, em função da gravidade da infração. Portaria TCU no 34/2012 de 03 de fevereiro de 2012: Art. $1^{\circ}$ É fixado em $\mathrm{R} \$ 41.528,52$ (quarenta e um mil quinhentos e vinte e oito reais e cinquenta e dois centavos), para o exercício de 2012, o valor máximo da multa a que se refere o art. 58, caput, da Lei $\mathrm{n}^{\circ} 8.443$, de 16 de julho de 1992. 
e/ou penal correspondente. Tal providência, na prática, é comum, em especial quando do julgamento de contas irregulares.

Outra modalidade de sanção aponta para a sustação de contrato. Inicialmente incumbe ao Congresso Nacional sustar o contrato e solicitar de imediato que o Poder Executivo adote medidas (art. $71 \S^{\circ}-\mathrm{CF}$ ).

Entretanto, se tais entes, em noventa dias não efetivarem as medidas de sustação, o Tribunal de Contas decidirá a respeito da sustação (art. 71, §2 $2^{\circ}$ CF). Procedimento idêntico incumbe aos demais Tribunais de Contas, conforme art. 75 da CF.

Pode ainda acontecer a suspensão de direitos políticos, porém, como afirma Hélio Milesky ${ }^{223}$ não se trata propriamente de uma sanção imposta pelo Tribunal de Contas, mas sim uma consequência jurídica que decorre do julgamento irregular das contas.

A Lei Complementar $n^{\circ} 64$ de 18 de maio de 1990, aponta para os casos de inelegibilidade, e há previsão para aqueles que tiverem contas rejeitadas por irregularidade insanável, quando esgotados os recursos, ressalvada a apreciação do Poder Judiciário. O Tribunal de Contas deve comunicar à Justiça Eleitoral, locus em que será estabelecida a impossibilidade temporal do livre exercício dos direitos políticos.

\subsubsection{4 - Rede de Controle da Gestão Pública.}

Os Tribunais de Contas também podem e devem agir com auxilio de outras entidades na busca do aprimoramento da função do controle. Pontua-se, como exemplo, que em 25 de março de 2009 com a celebração de um Protocolo de Intenções iniciou-se a efetivação da chamada 'Rede de Controle da Gestão Pública' por meio da realização de Oficinas de Trabalho em Brasília e a implantação de Redes nos Estados ${ }^{224}$.

\footnotetext{
${ }^{223}$ MILESKI, Helio Saul. O Controle da Gestão Pública. São Paulo: RT. 2003.p.335

${ }^{224} \mathrm{http} / / / \mathrm{www} \cdot$ rededecontrole.gov.br/portal/page/portal/rededecontrole/sobre. Acesso em 09 de agosto de 2012.
} 
A Rede de Controle é um centro decisório interorganizacional que visa aprimorar a efetividade da função de controle do Estado sobre a gestão pública. Seu principal objetivo é o de desenvolver ações direcionadas à fiscalização da gestão pública, ao diagnóstico e combate à corrupção, ao incentivo e fortalecimento do controle social, ao compartilhamento de informações e documentos, ao intercâmbio de experiências e à capacitação dos seus quadros.

Para tanto, a estratégia adotada é a de ampliar e aprimorar, de modo expresso e efetivo a articulação de parcerias entre os órgãos públicos e as entidades, nas diversas esferas da Administração Pública, mediante a formação de rede de âmbito estadual e federal, bem como a interação da rede formada pelos signatários de acordos no âmbito estadual com a Rede de Controle da Gestão Pública.

Assinaram o Protocolo de Intenções as autoridades máximas de 17 instituições, a saber: Advocacia Geral da União (AGU), Associação Brasileira dos Tribunais de Contas dos Municípios (ABRACOM), Associação dos Membros dos Tribunais de Contas do Brasil (ATRICON), Associação Nacional do Ministério Público de Contas (AMPCON), Banco Central do Brasil (BACEN), Câmara dos Deputados (CD), Conselho da Justiça Federal (CFJ), Conselho Nacional de Justiça (CNJ), ControladoriaGeral da União (CGU), Ministério da Fazenda (MF), Ministério da Justiça (MJ), Ministério do Planejamento, Orçamento e Gestão (MPOG), Ministério da Previdência Social (MPS), Ministério Público Federal (MPF), Senado Federal (SF), Tribunal de Contas da União (TCU), Tribunal Superior Eleitoral (TSE).

Em 16 de abril de 2009, nas dependências do Tribunal de Contas da União, junto ao Instituto Serzedello Corrêa, foi realizada $1^{\text {a }}$ Oficina de Trabalho da Rede de Controle da Gestão Pública, com a presença de vinte e cinco representantes das instituições signatárias do Protocolo de Intenções.

No evento, decidiu-se pela constituição de três grupos de trabalho, cada um voltado à discussão dos seguintes temas: a) Tipologia de Irregularidades, visando levantamento das principais tipologias de irregularidades cometidas pelos gestores públicos; b) Auditoria de Obras Públicas, para o aprimoramento da fiscalização de obras públicas e c) Tomada de Contas Especiais com escopo de mapeamento do processo de 
Tomada de Contas Especial. Em seguida no dia 31 de abril de 2010 foram constituídos dois novos grupos de trabalho para a) Cadastro Integrado de Condenações por Ilícitos Administrativos e b) Terceirização.

Observa-se que o sistema de controle, como um todo, se aprimora com a interação entre os órgãos e entidades envolvidos na sua realização.

No Estado de São Paulo foi firmado em 25 de março de 2010 (com publicação no DOU de 04 de maio de 2010, p.177) acordo, com prazo de sessenta meses (a partir da publicação), envolvendo o Tribunal de Contas da União e as seguintes outras entidades e/ou órgãos da administração pública: Tribunal de Contas do Estado de São Paulo,Tribunal de Contas do Município de São Paulo, Advocacia Geral da União, Ministério Publico Federal, Ministério Público do Estado de São Paulo, Procuradoria Regional da Fazenda Nacional da $3^{\text {a }}$ Região, Controladoria-Geral da União no Estado de São Paulo, Superintendência da Policia Federal no Estado de São Paulo e Superintendência da Receita Federal - $8^{\mathrm{a}}$ Região Fiscal.

Pretende-se ampliar e aprimorar, de modo expresso e efetivo, a articulação de parcerias entre os órgãos públicos e as entidades partícipes, nas diversas esferas da Administração Pública com atuação no Estado de São Paulo, mediante a formação de rede de âmbito estadual, e, adicionalmente, a interação da rede formada pelos signatários do acordo com a Rede de Controle da Gestão Pública, com a finalidade de desenvolver ações direcionadas à fiscalização da gestão pública, ao diagnóstico e combate à corrupção, ao incentivo e fortalecimento do controle social, ao tráfego de informações e documentos, ao intercâmbio de experiências e à capacitação dos seus quadros ${ }^{225}$.

Outras avenças foram realizadas nos distintos Estados da federação com o mesmo escopo.

${ }^{225} \mathrm{http} / / /$ www.rededecontrole.gov.br/portal/page/portal/rededecontrole/acordos Acesso em 09 de agosto de 2012. 
4.1.2.5 - O Tribunal de Contas de São Paulo.

Para o Estado de São Paulo ${ }^{226}$ temos que o Tribunal de Contas do Estado é estruturado pela divisão de funções entre seus órgãos deliberativos (Tribunal Pleno, Primeira e Segunda Câmara e Julgador Singular), órgãos de administração superior (Presidência, Vice-Presidência e Corregedoria), órgãos especiais (Corpo de Auditores), órgãos de direção, supervisão e controle (Secretaria-Diretoria Geral, Departamento Geral de Administração e Departamento de Tecnologia da Informação), órgãos auxiliares (Gabinete Técnico da Presidência), unidades regionais de controle espalhadas por diversos Municípios, Procuradoria da Fazenda do Estado e Ministério Público do Tribunal de Contas, este composto por oito procuradores, chefiados pelo Procurador Geral.

É composto por sete Conselheiros, nomeados pelo Governador do Estado e escolhidos por este e pela Assembleia Legislativa, entre os cidadãos brasileiros que preencham os requisitos previstos no art. $31, \S 1^{\circ}$, da Constituição Estadual ${ }^{227}$.

Como órgãos deliberativos, há o Tribunal Pleno, composto por todos os Conselheiros e Auditores e presidido pelo Presidente do TCE, as $1^{\text {a }}$ e $2^{\text {a }}$ Câmaras, compostas, cada uma, por três Conselheiros, sendo a primeira presidida pelo VicePresidente do TCE e a segunda pelo Conselheiro mais antigo, e os Julgadores Singulares.

Há, ainda, o órgão de Administração Superior composto pela Presidência, Vice-Presidência e Corregedoria, cabendo às primeiras as funções de direção do Tribunal e à última a apuração de desvios funcionais dos Conselheiros, Procurador-Geral, membros do Ministério Público e Auditores.

\footnotetext{
${ }^{226}$ A escolha de uma breve referência ao TCE-SP se deu, evidentemente, em virtude do autor ser paulista, o trabalho estar sendo apresentado na Universidade de São Paulo e ainda em homenagem à forma como foi recebido no respectivo Tribunal para pesquisas.

${ }^{227}$ Art. 31. (...) $\$ 1^{\circ}$ - Os Conselheiros do Tribunal serão nomeados dentre brasileiros que satisfaçam os seguintes requisitos: 1 - mais de trinta e cinco e menos de sessenta e cinco anos de idade; 2 - idoneidade moral e reputação ilibada; 3 - notórios conhecimentos jurídicos, contábeis, econômicos e financeiros ou de administração pública; 4 - mais de dez anos de exercício de função ou de efetiva atividade profissional que exija conhecimentos mencionados no item anterior.
} 
Aos auditores cabem, além da instrução e acompanhamento dos processos, as funções de substituição dos Conselheiros e eventuais atribuições que lhes forem designadas.

Os órgãos de direção, supervisão e controle, compostos pela SecretariaDiretoria Geral, Departamento Geral de Administração e Departamento de Tecnologia da Informação têm como função precípua o auxílio técnico e a execução de serviços da Secretaria do Tribunal e o Tribunal conta, ainda, com unidades regionais de fiscalização, espalhadas pelos Municípios, a fim de dar agilidade ao atendimento realizado, a partir de sua descentralização.

O Ministério Público do Tribunal de Contas, chefiado pelo ProcuradorGeral, é composto por subprocuradores-gerais e procuradores, aprovados por concurso público de provas e títulos.

Basicamente, a atividade de controle externo exercida pelo TCE pode ser dividida nas seguintes ações: julgamento das contas do Governador; julgamento das contas da Administração Financeira do Município; processamento dos contratos, convênios e atos jurídicos análogos; exame prévio de editais; consultas; e apuração de denúncias e representações.

O julgamento das contas do Governador será realizado pelo órgão legislativo competente para tanto, após parecer prévio do TCE que servirá de embasamento para a tomada de decisão acerca da sua regularidade, enquanto que a prestação de contas da Administração Financeira do Município será encaminhada à Diretoria de Fiscalização ou às Unidades Regionais para inspeção e fiscalização, por meio de processo de Tomada de Contas e o processamento de contratos, convênios e atos jurídicos análogos é realizado por meio de procedimento de fiscalização comum, cabendo às Diretorias de Fiscalização e Unidades Regionais a instrução dos processos e às Assessorias Técnico-Jurídica e Secretaria-Diretoria Geral as manifestações quanto ao mérito.

No exame prévio de edital será analisada a viabilidade das condições inseridas no instrumento convocatório, a fim de assegurar a qualidade das contratações públicas, enquanto que também é atribuição do Tribunal de Contas do Estado a resposta a 
consultas formuladas acerca de dúvidas suscitadas na aplicação de disposições legais concernentes à matéria de sua competência. Detém ainda o TCE-SP competência para a apuração de denúncias e representações a ele submetidas acerca das matérias previstas como de sua atribuição.

As fiscalizações exercidas podem ser iniciadas por iniciativa própria, por solicitação da Assembleia Legislativa, por denúncias ou por representações. Uma vez iniciado o processo de fiscalização por quaisquer das formas admitidas, este será distribuído ao Conselheiro responsável, conforme o critério de distribuição estabelecido no Regimento Interno do TCE/SP que traz regras de competência a depender da espécie de processo instaurado.

Será de responsabilidade das Diretorias de Fiscalização e Unidades Regionais a instrução dos processos, conforme a facilidade da unidade para obter as informações necessárias ao prosseguimento da fiscalização, enquanto que uma equipe técnica responsável elaborará Relatório com os apontamentos acerca da fiscalização, encaminhando-o à apreciação do Conselheiro Relator que pode ou não acolher as providências propostas pela unidade técnica, abrindo prazo para que as partes interessadas se manifestem.

Os responsáveis pelo objeto da fiscalização serão citados para apresentar alegações de defesa ou novos documentos, sendo os autos encaminhados à Assessoria Técnica Jurídica e posteriormente à Secretaria-Diretoria Geral que, após manifestação quanto ao mérito das alegações apresentadas, remeterão o processo para nova apreciação do Conselheiro Relator.

Sendo as justificativas apresentadas pelos responsáveis acolhidas, o processo será arquivado. Todavia, caso não haja acolhimento das justificativas apresentadas, o Conselheiro poderá determinar a aplicação de multa (caso não haja irregularidades com débitos).

As partes podem recorrer da decisão que aplicar multa aos responsáveis, caso em que o recurso, sendo admitido, será distribuído a um novo Relator, que após instrução da unidade técnica decidirá acerca do processo, podendo determinar o seu 
arquivamento ou não prover o recurso, tornando a decisão que determinar as contas irregulares.

Se constatadas notícias de eventos mais graves (crimes, atos de improbidade), cópia da documentação deverá ser encaminhada ao Ministério Público Estadual para providências de sua alçada.

Sendo assim, é possível afirmar que a importância da atuação dos tribunais de contas é ímpar no cenário da evolução do sistema de fiscalização e controle do patrimônio público.

\section{2 - O Ministério Público}

\subsection{1 - Histórico}

Seguindo a linha de raciocínio acima, também será apresentado o histórico da Instituição do Ministério Público, desde seu surgimento no cenário da repartição de poderes.

É certo dizer que não existe unanimidade sobre a verdadeira origem do Ministério Público, porém é possível extrair de profundo ensinamento de Hugo Mazzilli ${ }^{228}$ com fulcro em diversos doutrinadores, referências às sua raízes remotas e também mais recentes.

Assim, passa-se, brevemente, a tal estudo.

Acredita-se que as primeiras referências guardem nexo com a figura dos magiaí, há mais de quatro mil anos no Egito. Eram funcionários diretos do rei e serviam a castigar os rebeldes, reprimir os violentos, proteger os cidadãos pacíficos, acolhendo pedidos dos homens justos perseguindo os mentirosos; ouviam as acusações apontando a solução diante dos textos legais e tomavam parte das instruções para descobrir a $\operatorname{verdade}^{229}$.

\footnotetext{
${ }^{228}$ MAZZILLI, Hugo Nigro. Regime Jurídico do Ministério Público. 6ª́Ed. São Paulo: Saraiva, 2007. p.37-44 ${ }^{229}$ VELLANI, Mario. Il pubblico ministero nel processo, Bologna, 1965, v.1, t.1, p.15; REZENDE FILHO, Gabriel de. Curso de direito processual civil, Saraiva, 1957, v.1, n.90, p.91 e LYRA, Roberto, Teoria e
} 
Também são mencionados fundamentos na Antiguidade clássica, seja nos éforos de Esparta, nos thesmotetis ou tesmótetas gregos, ou nas figuras romanas dos advocati fisci, proetores fiscalis, censores, defensor civitatis, irenacha, curiosi, stationarii, frumentarii ou procuratores caesaris ${ }^{230}$

Os censores podiam impor multas e as chamadas notas de infâmia, enquanto que os procuratores caesaris instituídos pelo imperador romano Augusto cuidavam da gestão dos domínios imperiais e da arrecadação de receitas, podendo ainda confiscar bens dos cidadãos condenados, mantendo interesse na persecução criminal.

No período da Idade Média há menção aos saions germânicos e aos bailos e senescais, encarregados de defender os senhores feudais em juízo, ou aos missi dominici e gastaldi, do direito longobardo, e também aos Gemeiner Anklager da Alemanha ("comum acusador" em tradução literal), encarregado de exercer a acusação, quando o particular permanecia inerte $^{231}$ ou mesmo no direito canônico junto ao vindex religiones ${ }^{232}$.

Invoca-se, de modo mais corrente, a origem junto aos procurateurs ou procureus du roi do direito francês sendo que doutrinadores italianos apontam a região da Pávia ou do Piemonte como ponto inicial, nas figuras dos advocatus de parte publica ou dos avogadori di comum dela repubblica veneta ou dos conservatori dele leggi di Firenze, reconhecido que estes últimos poderiam derivar daqueles primeiros. ${ }^{233}$

prática da promotoria pública, Cap.1, 1 apud MAZZILLI, Hugo Nigro. Regime Jurídico do Ministério Público. 6ªd. São Paulo: Saraiva, 2007. p.37.

${ }^{230}$ Cf. Tourinho Filho, Processo Penal, Saraiva, 1982, v.2, Cap.22; Mario Vellani, Il pubblico ministero, cit., v.1,t.1, n.1, p.11; Octacilio Paula Silva, Ministério Público, Sugestões Literárias, 1981, p.4; José Henrique Pierangelli, Processo Penal; evolução histórica, Jalovi, 1983, p.180; Michèle-Laure Rassat, Le Ministère Public entre son passé et son avenir. Paris, Librairie Général de Droit et de Jurisprudence, 1967, apud MAZZILLI, Hugo Nigro. Regime Jurídico do Ministério Público. 6ª́ Ed. São Paulo: Saraiva, 2007. p.37

${ }^{231}$ Michèle-Laure Rassat, Le Ministère Public, cit, p.11; Vellani, Il pubblico minister, cit, v.1, t.1, p.13; Gabriel de Rezende Filho, Curso de direito processual civil, cit. V.1, n. 90, p.91; Moacyr Amaral Santos, Primeiras linhas de direito processual civil, Saraiva, 1978, v.1, n.96; Tourinho Filho, Processo penal, cit. V.2, p.289, apud MAZZILLI, Hugo Nigro. Regime Jurídico do Ministério Público. $6^{a} E d$. São Paulo: Saraiva, 2007. p.37

${ }^{232}$ TORNAGHI, Hélio, Compêndio de processo penal, Konfino, 1967, v.1, p.375

${ }^{233}$ Cf. Mario Velanni, Il pubblico ministero, cit.v.1, t.1, p.13 e 18, citando CHECCHINI, Vincenzo Manzini, Trattato di diritto processuale penale italiano, Torino, 1924, v.2, p.260, apud MAZZILLI, Hugo Nigro. Regime Jurídico do Ministério Público. $6^{\mathrm{a} E d}$. São Paulo: Saraiva, 2007. p.38. 
Fato é que a doutrina considera, de forma usual, que a França é o berço do Ministério Público, conforme estudos de Faustin Hélie e Esmein ${ }^{234}$, invocando-se a ordenança de março de 1302, de Felipe IV, o Belo, Rei de França, como o primeiro texto legislativo a tratar de modo objetivo sobre os procuradores do rei ("procuratores nostri”) impondo-lhes que prestassem o mesmo juramento dos juízes, com vedação de patrocínio de quaisquer outros que não o próprio rei.

Com evolução lenta, somente em 1790 um decreto deu vitaliciedade aos procuradores, sendo que outro decreto do mesmo ano dividiu as funções em um comissário do rei e um acusador público, o primeiro, nomeado pelo soberano e inamovível com missão de velar pela aplicação da lei e pela execução dos julgados, além do poder de recurso das decisões dos tribunais e o segundo, eleito pelo povo com o único encargo de sustentar as acusações perante os tribunais, considerado, entretanto, que houve retrocesso na época, diante da limitação do papel de ambos ${ }^{235}$.

Refere-se que a revolução francesa estruturou de forma mais adequada o Ministério Público, enquanto instituição, diante de garantias conferidas a seus integrantes, porém foram os textos napoleônicos que, de fato, instituíram o Ministério Público nos moldes atuais, vindo desta época a expressão parquet para referí-lo.

Aliás, tal termo (parquet) significa assoalho e assim como a expressão magistratures débout (magistratura em pé) e les gens du roi (as pessoas do rei) provém da mesma tradição e isto porque os procuradores do rei, antes de adquirirem a condição de magistrados e terem assento ao lado dos juízes, tiveram inicialmente assento sobre o assoalho da sala de audiências, em vez de tê-lo sobre o estrado, lado a lado com a 'magistratura sentada'.

O Ministério Público brasileiro guarda suas origens no direito lusitano, além daquelas acima mencionadas. Remotamente, em 1289, no reinado de D Afonso III existiu

\footnotetext{
${ }^{234}$ HÉLIE, Faustin, Traité de l'instruction criminelle ou théorie du Code d'instruction criminelle, Paris, $2^{\mathrm{a}}$ ed. 1866 e ESMEIN, Histoire de la procédure criminelle em France et spécialement de la procédure inquisitoire depuis le XIII siècle jusqu'à nos jours, Paris, 1882, apud MAZZILLI, Hugo Nigro. Regime Jurídico do Ministério Público. 6ª́Ed. São Paulo: Saraiva, 2007. p.38

${ }^{235}$ RASSAT, Michèle-Laure. Le Ministère Public entre son passé et son avenir. Paris, Librairie Général de Droit et de Jurisprudence, 1967, apud MAZZILLI, Hugo Nigro. Regime Jurídico do Ministério Público. 6Ed. São Paulo: Saraiva, 2007. p.39
} 
o cargo de procurador da Coroa, com caráter permanente, ao mesmo tempo em que na Europa se constituíam tribunais regulares ${ }^{236}$. Quando do reinado de D. João I (1384/1422) o "Livro das Leis e Posturas" apresenta disposições reguladoras de intervenção de procuradores do Rei em causas penais e referência à atuação dos procuradores de justiça na chamada 'Casa de Suplicação' 237 .

Ainda nas Ordenações Afonsinas refere-se o "Procurador de Nossos Feitos"238 cujo traço de Ministério Público foi desenvolvido nas ordenações posteriores, sendo as Ordenações Manuelinas considerada a principal fonte de citação doutrinária ${ }^{239} \mathrm{em}$ especial por destinar título específicos no Livro I para o "Procurador de Nossos Feitos" (Título XI) e para o "Prometor da Justiça da Casa da Sopricaçam" (Tìtulo XII) a quem cabia "ver todas as inquirições que o escrivão era obrigado a encaminhar-lhe no prazo de oito dias, podendo requerer que se mandasse prender e proceder contra os seguros e presos, contra os quais formava libelos"240.

As Ordenações Filipinas de 1603 trouxeram Títulos próprios no Livro I, para cuidar do "Procurador dos Feitos da Coroa" (XII), do "Procurador dos Feitos da Fazenda (XIII), do "Promotor da Justiça da Casa de Supplicação" (XV) e do "Promotor de Justiça da Casa do Porto" (XLIII).

O Título XV diz que "Ao Desembargador da casa da Supplicação, que servir de Promotor da Justiça, pertence requerer todas as cousas, que tocam á Justiça"241.

\footnotetext{
${ }^{236}$ PIERANGELLI, José Henrique. Processo Penal. Evolução histórica. Jalovi, 1983, p.187.

${ }^{237}$ CABRAL NETTO, J. O Ministério Público na Europa Latina. Belo Horizonte, Imprensa Oficial de Minas Gerais, 1974.

238 "Mandamos que o Procurador de Nossos Feitos seja Leterado, e bem entendido, pera saber espertar, e aleegar as cousas, e razooes, que a Nossos Direitos perteencem, porque muitas vezes acontece, que por seu bom avisamento os Nossos Desembargadores som bem enformados, e ainda Nossos Direitos Reaaes acrescentados. Ao qual Mandamos que com grande diligencia, e muito amiude requeira, aos Veedores da Fazenda, e Contadores, e Juizes que lhe dem as enformaçoões, que ouverem dos Nossos Direitos nos feitos, que se trautam, ou trautarem perante os Nossos Juizes (...) e veja, e procure bem todos os feitos da Justiça, e das Viuvas, e dos Orfoõs, e miseravees pessoas, que aa Nossa Corte vierem, sem levando delles dinheiro, nem outra cousa de solairo, sem vogando, nem procurando outros nenhuus feitos, que a Nos nom perteeçam sem Nosso especial Mandado, como dito he".

${ }^{239}$ ALMEIDA, J, Canuto Mendes de. Processo Penal, ação e jurisdição, Revista dos Tribunais, 1975, p. 218

${ }^{240}$ MAZZILLI, Hugo Nigro. Regime Jurídico do Ministério Público. 6ªd. São Paulo: Saraiva, 2007. p.41

${ }^{241}$ Em 27 de julho de 1627, Carta do Rei de Portugal encarrega o Promotor da Justiça de denunciar os naturais do Reino de Portugal que cometessem crimes no Brasil
} 
Portanto, é possível se afirmar que o Ministério Público brasileiro, conquanto na França estivessem surgindo procuradores de modo contemporâneo àqueles do direito lusitano, desenvolveu-se, efetivamente a partir dos procuradores do Rei de Portugal, ainda que calcado nas ideias iluministas consagradas na Revolução Francesa.

Já a expressão 'Ministério Público', acredita-se tenha derivado, na prática do exercício dos advogados e procuradores do Rei que falavam de sua própria função, mistér ou ministério acrescidos do vocábulo 'público' para designar o interesse que deveriam defender. Originada na França, derivou para outro locais.

No Brasil o primeiro texto com a expressão, segundo Abdon de Mello, ratificada por José Henrique Pierangelli, encontra-se no art. 18 do Regimento das Relações do Império, de 02 de maio de $1847^{242}$.

4.2.2 - O Ministério Público e o perfil atual.

4.2.2.1 - Disciplina e conceito.

Atualmente, disciplinam a atividade do Ministério Público em nível nacional, tanto a Constituição Federal ${ }^{243}$ como a Lei Orgânica Nacional do Ministério Público (LONMP), Lei $\mathrm{n}^{\circ} \quad 8.625 / 93$ (equivocadamente Lei Ordinária, e não Complementar), sendo que para o Ministério Público da União (Federal, do Trabalho, Militar e do Distrito Federal e Territórios) foi editada a Lei Orgânica do Ministério Público da União (LOMPU), Lei Complementar no 75/93, e em São Paulo a Lei Complementar Estadual nº 734 de 26 de novembro de 1993 (LOMPSP) disciplinando o Ministério Público do Estado de São Paulo ${ }^{244}$.

\footnotetext{
${ }^{242}$ PIERANGELLI, José Henrique. Processo Penal. Evolução histórica. Jalovi, 1983, p.192

${ }^{243}$ CF - Capítulo IV - Das Funções Essenciais à Justiça - Seção I - Do Ministério Público. Art. 127. O Ministério Público é instituição permanente, essencial à função jurisdicional do Estado, incumbindo-lhe a defesa da ordem jurídica, do regime democrático e dos interesses sociais e individuais indisponíveis. $\S 1^{\circ}$ São princípios institucionais do Ministério Público a unidade, a indivisibilidade e a independência funcional. ${ }^{244}$ Instituição que o autor desta dissertação integra desde 1989, cujo cargo atual de Procurador de Justiça é o último degrau da carreira.
} 
Conceitua-se segundo a Lei Maior como “... instituição permanente, essencial à função jurisdicional do Estado, incumbindo-lhe a defesa da ordem jurídica, do regime democrático e dos interesses sociais e individuais indisponíveis” (art. 127).

Permanente significa dizer que parte da soberania do Estado ali está manifestada. O poder constituinte originário indicou que não pode o poder constituinte derivado suprimir ou deformar a Instituição, sob pena de, indiretamente estar burlando o próprio princípio. Considera-se que o Ministério Público é verdadeira cláusula pétrea, não podendo ser abolido do texto constitucional ${ }^{245}$.

Essencial à função jurisdicional mostra que sua atuação é imprescindível para que o Poder Judiciário possa realizar a Justiça dentro do espectro da divisão de Poderes do Estado, embora a expressão sofra críticas ${ }^{246}$.

O zelo pela ordem jurídica, pelo regime democrático e pelos interesses sociais e individuais indisponíveis mostra em última análise o cuidado com o próprio interesse público. À sociedade interessa que seja preservado o regime escolhido para que assim seja governada, mantido o equilíbrio de poderes segundo a divisão de funções das atividades do Estado, assim como que alguém possa dar conta da defesa dos interesses convenientes à coletividade, sejam eles sociais ou individuais indisponíveis ${ }^{247}$.

Para que a letra da lei não resultasse em mera formalidade, foi dotado o Ministério Público de mecanismos efetivos para sua atuação.

\footnotetext{
${ }^{245}$ RITT, Eduardo. O Ministério Público como instrumento de democracia e garantia constitucional. Porto Alegre: Livraria do Advogado Editora. 2002. p. 181.

${ }^{246}$ Hugo Mazzilli diz que ora a expressão diz mais do que deveria (visto que o Ministério Público não atua em todas as causas) ora diz menos (posto que existem funções que exacerbam a prestação jurisdicional, como a fiscalização de Fundações e prisões, ou a presidência do inquérito civil, por exemplo) in MAZZILLI, Hugo Nigro. Regime Jurídico do Ministério Público. 6ªd. São Paulo: Saraiva, 2007. p.109-110.

${ }^{247}$ Extrai-se do Código do Consumidor que: I - interesses ou direitos difusos, assim entendidos, para efeitos deste Código, os transindividuais, de natureza indivisível, de que sejam titulares pessoas indeterminadas e ligadas por circunstâncias de fato; II - interesses ou direitos coletivos, assim entendidos, para efeitos deste Código, os transindividuais de natureza indivisível de que seja titular grupo, categoria ou classe de pessoas ligadas entre si ou com a parte contrária por uma relação jurídica base; III - interesses ou direitos individuais homogêneos, assim entendidos os decorrentes de origem comum. Enquanto que Interesses e direitos coletivos, por sua vez, são os transindividuais de natureza indivisível de que seja titular grupo, categoria ou classe de pessoas ligadas entre si ou com a parte contrária por uma relação jurídica-base.
} 
Assim, detém orçamento próprio, devendo elaborar sua proposta orçamentária dentro dos limites estabelecidos na lei de diretrizes orçamentárias ${ }^{248}$ enquanto que se não encaminhar a respectiva proposta orçamentária dentro do prazo estabelecido naquela lei, o Poder Executivo considerará, para fins de consolidação da proposta orçamentária anual, os valores aprovados na lei orçamentária vigente, ajustados de acordo com os limites estipulados na forma do $\S 3^{\circ}$ do art. 127 da CF e se a proposta orçamentária de que trata este artigo for encaminhada em desacordo com os limites estipulados na forma do $\S 3^{\circ}$, o Poder Executivo procederá aos ajustes necessários para fins de consolidação da proposta orçamentária anual.

Obedecendo as características do regime brasileiro em que a centralização (pelo menos formal) não é a regra, segundo o art. 128 da CF, o Ministério Público abrange: I - o Ministério Público da União, que compreende: a) o Ministério Público Federal; b) o Ministério Público do Trabalho; c) o Ministério Público Militar; d) o Ministério Público do Distrito Federal e Territórios e II - os Ministérios Públicos dos Estados.

Chefiam os respectivos Ministérios Públicos, o Procurador Geral (da Republica para o MPF e de Justiça para os Estados) e a garantia da independência se encontra no fato de que uma vez escolhido pelo Chefe do Poder Executivo (após eleição interna nos Estados formando lista tríplice e na União após aprovação do Senado) somente pode ser destituído após processo junto ao Poder Legislativo e com oportunidade de ampla defesa. Respeita-se o equilíbrio de poderes sem a possibilidade (formal) de pressões junto ao exercício do cargo.

Afirma-se que as pressões inexistem, entretanto, na prática, podem acontecer, seja porque ainda não se atingiu ideal perseguido pelos membros da instituição

\footnotetext{
${ }^{248}$ Dispõe a Lei de Diretrizes Orçamentárias (Lei no 12.708 de 17 de agosto de 2012) que: Art. 22. Os órgãos dos Poderes Legislativo e Judiciário e do Ministério Público da União encaminharão à Secretaria de Orçamento Federal do Ministério do Planejamento, Orçamento e Gestão, por meio do Sistema Integrado de Planejamento e Orçamento - SIOP, até 15 de agosto de 2012, suas respectivas propostas orçamentárias, para fins de consolidação do Projeto de Lei Orçamentária de 2013, observadas as disposições desta Lei. $\S 1^{\circ}$ - As propostas orçamentárias dos órgãos do Poder Judiciário e do Ministério Público da União, encaminhadas nos termos do caput, deverão ser objeto de parecer do Conselho Nacional de Justiça e do Conselho Nacional do Ministério Público, de que tratam os arts. 103-B e 130-A da Constituição, respectivamente, a ser encaminhado à Comissão Mista a que se refere o $\$ 1^{\circ}$ do art. 166 da Constituição, até 28 de setembro de 2012, com cópia para a Secretaria de Orçamento Federal do Ministério do Planejamento, Orçamento e Gestão. $2^{\circ}$ Não se aplica o disposto no $\S 1^{\circ}$ ao Supremo Tribunal Federal, ao Conselho Nacional de Justiça, ao Ministério Público Federal e ao Conselho Nacional do Ministério Público.
} 
de escolha direta por eleição do mandatário, seja pelo dispositivo que indica que durante a execução orçamentária do exercício não poderá haver a realização de despesas ou a assunção de obrigações que extrapolem os limites estabelecidos na lei de diretrizes orçamentárias, exceto se previamente autorizadas, mediante a abertura de créditos suplementares ou especiais (art. $127, \S 6^{\circ}$ ), o que significa dizer que se o orçamento for insuficiente, dependerá o Ministério Público da boa vontade dos Poderes Executivo e Legislativo (considerando-se que nem sempre o limite de $0,6 \%$ ou $2 \%$ previstos na Lei de Responsabilidade Fiscal para os Ministérios Públicos da União e dos Estados, respectivamente, costuma ser atingido $)^{249}$.

As garantias constitucionais para os membros são a vitaliciedade, após dois anos de exercício, não podendo perder o cargo senão por sentença judicial transitada em julgado; a inamovibilidade, salvo por motivo de interesse público, mediante decisão do órgão colegiado competente do Ministério Público, por voto de dois terços de seus

\footnotetext{
${ }^{249}$ Segundo a Lei de Diretrizes Orçamentárias (Lei n 12.708 de 17 de agosto de 2012) em seu art. 39 as propostas de abertura de créditos suplementares autorizados na Lei Orçamentária de 2013, ressalvado o disposto nos §§ 1o e 9o, serão submetidas ao Presidente da República, acompanhadas de exposição de motivos que inclua a justificativa e a indicação dos efeitos dos cancelamentos de dotações, observado o disposto no $\S 80$ do art. 38 . - $\S 1^{\circ}$ Os créditos a que se refere o 'caput', com indicação de recursos compensatórios dos órgãos dos Poderes Legislativo e Judiciário e do Ministério Público da União, nos termos do inciso III do § 1 o do art. 43 da Lei no 4.320, de 1964, serão abertos, no âmbito desses Poderes e Órgão, observadas as normas estabelecidas pela Secretaria de Orçamento Federal do Ministério do Planejamento, Orçamento e Gestão e o disposto no § 2o deste artigo, por atos: I - dos Presidentes da Câmara dos Deputados, do Senado Federal e do Tribunal de Contas da União; II - dos Presidentes do Supremo Tribunal Federal, do Conselho Nacional de Justiça, do Conselho da Justiça Federal, do Conselho Superior da Justiça do Trabalho, dos Tribunais Superiores e do Tribunal de Justiça do Distrito Federal e dos Territórios; e III - do ProcuradorGeral da República e do Presidente do Conselho Nacional do Ministério Público. § $2^{\circ}$ Quando a aplicação do disposto no §1o envolver mais de um órgão orçamentário, no âmbito dos Poderes Legislativo e Judiciário e do Ministério Público da União, os créditos serão abertos por ato conjunto dos dirigentes dos órgãos envolvidos, conforme indicado nos incisos I, II e III do referido parágrafo, respectivamente. $\S 3^{\circ} \mathrm{Na}$ abertura dos créditos na forma do $\S 1 \mathrm{o}$, fica vedado o cancelamento de despesas: I - financeiras para suplementação de despesas primárias; II - obrigatórias, de que trata o Anexo V, exceto para suplementação de despesas dessa espécie; e III - discricionárias, conforme definidas na alínea "b" do inciso II do $\S 40$ do art. 7o, para suplementação de despesas obrigatórias, de que trata o Anexo V. § $4^{\circ}$ As aberturas de créditos previstas no $\S$ 1o, no âmbito do Poder Judiciário, deverão ser comunicadas ao Conselho Nacional de Justiça e, no âmbito do Ministério Público da União, ao Conselho Nacional do Ministério Público. $\$ 5^{\circ}$ As propostas de créditos suplementares ao orçamento dos órgãos do Poder Judiciário e do Ministério Público da União, cujas aberturas dependam de ato do Poder Executivo, serão enviadas concomitantemente ao Conselho Nacional de Justiça e ao Conselho Nacional do Ministério Público, respectivamente, para emissão de parecer. $\$ 6^{\circ} \mathrm{O}$ parecer a que se refere o §5o deverá ser encaminhado à Secretaria de Orçamento Federal do Ministério do Planejamento, Orçamento e Gestão como forma de subsídio à análise das solicitações de créditos suplementares. $\S 7^{\circ} \mathrm{O}$ disposto nos $\S \S 40$ e 5o não se aplica ao Supremo Tribunal Federal, ao Conselho Nacional de Justiça, ao Ministério Público Federal e ao Conselho Nacional do Ministério Público. $\S 8^{\circ}$ Os créditos de que trata o $\S 1$ o serão incluídos no SIAFI, exclusivamente, por intermédio de transmissão de dados do SIOP. $\S 9^{\circ}$ O Presidente da República poderá delegar, no âmbito do Poder Executivo, aos Ministros de Estado, a abertura dos créditos suplementares a que se refere o caput.
} 
membros, assegurada ampla defesa; e a irredutibilidade de vencimentos, observado, quanto à remuneração, o que dispõem os arts. 37, XI, 150, II, 153, III, 153, § $2^{\circ}$, I da CF.

Enquanto que existem vedações, a saber: receber, a qualquer título e sob qualquer pretexto, honorários, percentagens ou custas processuais; exercer a advocacia; participar de sociedade comercial, na forma da lei; exercer, ainda que em disponibilidade, qualquer outra função pública, salvo uma de magistério; exercer atividade políticopartidária; receber, a qualquer título ou pretexto, auxílios ou contribuições de pessoas físicas, entidades públicas ou privadas, ressalvadas as exceções previstas em lei e exercer a advocacia no juízo ou tribunal do qual se afastou, antes de decorridos três anos do afastamento do cargo por aposentadoria ou exoneração.

\subsubsection{2 - Funções Institucionais.}

As funções do Ministério Público só podem ser exercidas por integrantes da carreira, que deverão residir na comarca da respectiva lotação, salvo autorização do chefe da instituição e o ingresso na carreira far-se-á mediante concurso público de provas e títulos, assegurada a participação da Ordem dos Advogados do Brasil em sua realização, exigindo-se do bacharel em direito, no mínimo, três anos de atividade jurídica e observando-se, nas nomeações, a ordem de classificação.

São funções institucionais do Ministério Público: promover, privativamente, a ação penal pública, na forma da lei; zelar pelo efetivo respeito dos Poderes Públicos e dos serviços de relevância pública aos direitos assegurados na Constituição, agindo mediante as medidas necessárias à sua garantia; promover o inquérito civil e a ação civil pública, para a proteção do patrimônio público e social, do meio ambiente e de outros interesses difusos e coletivos; promover a ação de inconstitucionalidade ou representação para fins de intervenção da União e dos Estados, nos casos previstos na Constituição.

Também: defender judicialmente os direitos e interesses das populações indígenas; expedir notificações nos procedimentos administrativos de sua competência, requisitando informações e documentos para instruí-los, na forma da lei complementar respectiva; exercer o controle externo da atividade policial, na forma de lei complementar; requisitar diligências investigatórias e a instauração de inquérito policial, indicados os 
fundamentos jurídicos de suas manifestações processuais; exercer outras funções que lhe forem conferidas, desde que compatíveis com sua finalidade, sendo-lhe vedada a representação judicial e a consultoria jurídica de entidades públicas.

Por vezes há polêmica quanto à extensão da atribuição. Em decisão, diante de divergência proposta, no Recurso Especial 1.119.116-SP (2009), o Superior Tribunal de Justiça decidiu que o Ministério Público tem legitimidade para promover a execução de título consubstanciado em decisão do Tribunal de Contas. Modificara acórdão proferido que atribuía até então ilegitimidade ao parquet, fixando-a com exclusividade na Fazenda Municipal.

Interessante a questão na medida em que se a Fazenda se negasse a executar o título, o Ministério Público poderia mover ação de improbidade em face do Procurador municipal diante da omissão na recomposição do patrimônio público, enquanto ausente aquela legitimidade concorrente. Entretanto, com a alteração do que fora decidido, não mais caberia aquela modalidade de ação para resgate da probidade, posto que o membro do parquet deveria, então, se substituir ao da Fazenda no caso de omissão deste.

Observa-se que há um ponto conflituoso no espectro de fiscalização entre as diferentes instituições e a busca da recomposição ora do erário ora da probidade. Entretanto, é certo que a ampliação do rol em favor da proteção do patrimônio público é positiva para a sociedade e afasta a criação de relações tensas entre distintas Instituições.

Assim, importa fixar que a fiscalização da administração pública e do patrimônio público é imperiosa ao Ministério Público. Nota-se que detém funções específicas de controle e fiscalização e de proteção aos direitos fundamentais bem como instrumentos legais que lhe permitem exercer, de fato, seu mistér.

\subsubsection{3 - A fiscalização da administração pública exercida pelo Ministério Público.}

No exercício de suas atribuições, por vezes, assim como o Tribunal de Contas, o Ministério Público, pode diretamente efetivar ações e em outras necessita da busca do Poder Judiciário. Assim, temos como exemplo as recomendações em autos de inquéritos civis via Promotor de Justiça, até a verificação de crimes contra a administração 
pública ou ainda processos por atos de improbidade administrativa cuja atuação do Ministério Público será diante do Poder Judiciário.

Sobre o tema da fiscalização pelo Ministério Público quanto aos atos praticados pelos administradores públicos e na proteção do patrimônio público, podemos afirmar que é da essência da Instituição exercer tal função, como se observa das atribuições mencionadas. Entretanto, além dos instrumentos legais oriundos do Poder Legislativo outros de natureza interna são percebidos.

Cite-se a existência de duas Súmulas e as respectivas justificativas, do Conselho Superior do Ministério Público de São Paulo (órgão com incumbência de rever arquivamentos de inquéritos civis, podendo determinar, em afastando a proposta de arquivamento, que seja proposta ação civil) ${ }^{250}$.

SÚMULA $n^{\circ} 33$ - “O Conselho Superior do Ministério Público homologará o arquivamento de inquéritos civis ou assemelhados que tenham por objeto irregularidades simplesmente formais praticadas no âmbito da administração pública, como tais se considerando aquelas relativas a não existência de livros e controles ou sua incorreção, contabilidade ou tesouraria deficiente e inadequado, controle da dívida ativa e de bens, caso não existam indícios de que tais faltas, por ação ou omissão, foram meios para a prática de ato que encontre adequação na Lei 8.429/92.".

Fundamento - O Ministério Público vem recebendo inúmeras representações e peças de informação dando conta de irregularidades na Administração Pública, onde vige, dentre outros, o princípio da legalidade. É certo que as formalidades são estabelecidas pela lei para salvaguarda de interesse maior, qual seja, o da probidade administrativa. Muitas vezes, todavia, é constatado que a forma não foi cumprida por desatenção, desconhecimento ou despreparo do agente público, constituindo-se em irregularidade meramente formal, que não se traduz em hipótese em que é necessária a intervenção do Ministério Público.

${ }^{250}$ www.mp.sp.gov.br/conselho - Acesso em 12/08/12 
Na linha do direcionamento dos trabalhos do Ministério Público na área dos interesses difusos, urge sejam reservados esforços para a investigação de fatos que possam dar suporte ao ajuizamento de ação civil pública, possibilitando-se o arquivamento de procedimento em que os fatos noticiados sejam aqueles constantes da súmula. Ressalve-se que a vocação dos membros da Instituição será suficiente para analisar se as irregularidades noticiadas constituem meio para a prática de outras condutas que infrinjam o dever de probidade administrativa e que, bem por isto, demandarão acurada investigação. A proposta tem esta finalidade, buscando-se maior eficácia na atividade ministerial.

SÚMULA no 34 - “O Conselho Superior homologará arquivamento de inquéritos civis ou assemelhados que tenham por objeto, apenas, dano ao erário quando, cumulativamente (1) não constituir ato de improbidade administrativa e (2) o prejuízo não alcançar expressão econômica relevante, assim entendido aquele que não seja superior a cinco saláriosmínimos. Neste caso, caberá ao Ministério Público apenas verificar se o colegitimado tomou as providências necessárias para o ressarcimento, evitando-se omissões dolosas."

Fundamento - É conhecida a sobrecarga do Ministério Público na área dos interesses difusos, conceito no qual se insere o de patrimônio público. $O$ ideal seria que nossa estrutura permitisse a apuração de todo e qualquer ato do qual resultasse dano ao erário. Contudo, não mais é dado desconhecer que no momento atual a realidade demonstra que isto não é possível. Urgente a racionalização do serviço, sendo imperioso que sejam traçados os caminhos prioritários na área.

A proposta tem esta finalidade, visando maior eficácia na atividade ministerial. Para tanto, buscou-se consignar que nos casos de dano ao erário de pequena expressão econômica a atuação do Ministério Público deve voltar-se a zelar para que a pessoa jurídica lesada tome as providências necessárias para o ressarcimento. Assim, a proteção do 
interesse difuso em questão, além de não sofrer prejuízo com a súmula ora apresentada, melhor será defendido, já que a atuação ministerial será voltada contra quem tem o dever de acionar o responsável.

Observa-se a presença do termo eficácia, como comando ao próprio órgão, podendo ser referência quanto à fiscalização interna e ao mesmo tempo diretriz para atuação no que tange à abordagem da violação de temas que impliquem em princípios que não o da legalidade para efeito de propositura de ação civil.

Fato é que as Súmulas servem de referência à atuação dos Promotores de Justiça e, ao mesmo tempo em que apresentam teses indicativas da forma de atuar da Instituição, admitem, de forma implícita a possibilidade do exercício do controle do patrimônio público.

Apontam a necessidade da eficiência e eficácia interna (portanto, apresentando formas de controle interno sobre o atuar do membro) e reconhecem parâmetros para a necessidade de controle dos demais órgãos da administração pública (ainda que com caráter não vinculativo).

Indicam, na verdade, que se a irregularidade no ato exarado pelo administrador público é formal, incumbe aos órgãos próprios de controle interno e externo (seja auditorias, sejam decisões do Tribunal de Contas) readequá-lo. É possível se inferir, então, que o processo preventivo pode surtir efeitos mais positivos do que o repressivo, restando para aqueles mais graves, com efetivo dano ao patrimônio público a ação do Ministério Público (o que se evidencia, pela gravidade das penas que podem vir a ser aplicadas diante de ações civis públicas, em especial por cometimento de atos de improbidade administrativa).

Outra evidência de tal afirmação é encontrada em publicação do Diário Oficial do Estado de São Paulo (03 de agosto de 2012), no Aviso n ${ }^{\circ}$ 192/12-CSMP:

O CONSELHO SUPERIOR DO MINISTÉRIO PÚBLICO, no uso de suas atribuições legais, e tendo em vista a existência de inúmeros outros casos semelhantes, em curso nas Promotorias de Justiça do Patrimônio Público e 
Social do Estado de São Paulo, sem caráter vinculativo, mas visando conferir subsídios para análise da matéria, pelos membros do Ministério Público oficiante, AVISA que, na sessão plenária realizada em 31.07.2012, o Conselho Superior, por unanimidade, acolheu os votos proferidos pelos Conselheiros Relatores Dora Bussab (PT 46147/12) e Walter Paulo Sabella (PT 39593/10), respectivamente, relativamente à necessidade, em regra, de prévia licitação, para contratação de empresa, pela Administração Pública Direta ou Indireta, para a prestação do serviço de concessão de vales ou cartões de refeição ou alimentação a seus funcionários, votos estes que poderão ser acessados, na íntegra, na página do Ministério Público/Conselho Superior/SIS MP Conselho, digitando-se os números do PT 46147/12 e do PT 39593/10.

É possível identificar comando imediato ao membro do Ministério Público, ainda que em caráter não vinculativo, e mediato ao próprio administrador público a quem incumbe a contratação de empresa para prestação de serviços referentes a vales de refeição.

Recorde-se que o Ministério Público também para efeito de seu funcionamento deve atuar da mesma forma que os demais entes da Administração Pública, portanto, deve realizar licitações para compra de material e concurso para o preenchimento de seus cargos. Da mesma forma, efetuar o próprio controle interno além de ser externamente controlado (tendo as contas submetidas ao Tribunal de Contas, dentre outros mecanismos de controle).

Encontra-se, dentre outras informações, no sitio eletrônico do Ministério Público do Estado de São Paulo ${ }^{251}$ a divulgação das sanções de natureza administrativa que impõem a pessoas físicas e jurídicas a proibição de licitar e contratar com qualquer órgão ou entidade da Administração Pública do Estado de São Paulo.

Tais sanções foram aplicadas, respectivamente, por autoridade legalmente investida da competência para prolação da decisão punitiva, sempre precedidas do devido

${ }^{251}$ http://www.sancoes.sp.gov.br/ - Acesso em 18.08.12 
processo legal, nos termos da legislação de regência, e estão sendo divulgadas quando já esgotada a possibilidade de interposição de recurso.

O licitante ou o contratado está relacionado pelo nome e/ou razão social, seguida do número da inscrição no Cadastro Nacional de Pessoas Jurídicas (CNPJ) ou no Cadastro Nacional de Pessoas Físicas (CPF), a origem e o número do processo em que foi exarada a decisão punitiva, o prazo de vigência da sanção aplicada e o fundamento legal.

Nota-se que vários comandos são atendidos de forma simultânea, tais como a transparência e a oportunidade de se saber de antemão (controle prévio) com quem é possível contratar sem óbices.

Entretanto, além das atribuições mencionadas do Ministério Público (sempre lembrando que ainda que não detenha exclusividade do polo ativo, na prática as ações de improbidade administrativa são movidas, em sua maioria por membros do parquet), a atuação no aspecto criminal é da essência da Instituição.

Incumbe ao membro do parquet a exclusividade da propositura da ação penal pública ${ }^{252}$ e o Código Penal (Decreto-Lei no 2.848 de 07 de dezembro de 1940, reformado pela Lei $\mathrm{n}^{\mathrm{o}} 7.209$ de 11 de julho de 1984 e outras alterações pontuais) prevê diversos crimes que implicam, de certa forma, em reconhecer que protegem o patrimônio público, servindo, portanto, ao Ministério Público como instrumento de sua fiscalização, já no aspecto repressivo.

\subsubsection{4 - Condutas violadoras do Patrimônio Público e o Código Penal.}

Para plena ilustração do tema desenvolvido, importa mencionar alguns tipos penais, identificando-se desde logo sua íntima ligação com o tema da fiscalização patrimonial no aspecto repressivo, até porque a descrição do tipo fala por sí, sendo suficiente para identificar a conduta e a respectiva punição possível.

\footnotetext{
252 Lembrando que as ações penais podem ser públicas ou privadas. Aquelas primeiras são ditas incondicionadas, quando independentes de qualquer condição de manifestação da parte ofendida e condicionadas quando se exige representação da vítima ou similar para que o Ministério Público venha a propô-la. Já as privadas apontam para movimento inicial da própria parte ofendida no que tange ao ingresso no juízo penal.
} 
Nota-se em primeiro, pelo art. $7^{\circ}$ do Código Penal que trata da extraterritorialidade, que se submete à lei brasileira mesmo que cometido no exterior o crime contra o patrimônio ou a fé pública da União, do Distrito Federal, de Estado, de Território, de Município, de empresa pública, sociedade de economia mista, autarquia ou fundação instituída pelo Poder Público.

Observa-se, já nos delitos locais, que existe figura para o crime de dano, consubstanciada em destruir, inutilizar ou deteriorar coisa alheia (art. 163), que se torna mais grave quando cometido contra o patrimônio da União, Estado, Município, empresa concessionária de serviços públicos ou sociedade de economia mista (inciso III), sendo que também se tutela o patrimônio de valor artístico, arqueológico ou histórico (art. 165), mediante a conduta de destruir, inutilizar ou deteriorar coisa tombada pela autoridade competente.

Também há preocupação com o patrimônio público ferroviário, marítimo ou mesmo na qualidade de direitos de locomoção e também de meios de comunicação:

Assim, há tipicidade no mero perigo de desastre ferroviário (art. 260 do CP) quando se apresenta como conduta punível impedir ou perturbar serviço de estrada de ferro, seja destruindo, danificando ou desarranjando, total ou parcialmente, linha férrea, material rodante ou de tração, obra-de-arte ou instalação; colocando obstáculo na linha; transmitindo falso aviso acerca do movimento dos veículos ou interrompendo ou embaraçando o funcionamento de telégrafo, telefone ou radiotelegrafia; ou ainda praticando outro ato de que possa resultar desastre. Penalmente, entende-se por estrada de ferro qualquer via de comunicação em que circulem veículos de tração mecânica, em trilhos ou por meio de cabo aéreo.

Também o atentado contra a segurança de transporte marítimo, fluvial ou aéreo (art. 261): Expor a perigo embarcação ou aeronave, própria ou alheia, ou praticar qualquer ato tendente a impedir ou dificultar navegação marítima, fluvial ou aérea e o atentado contra a segurança de outro meio de transporte, expondo-o a perigo (art. 262), impedindo ou dificultando o seu funcionamento. 
Há também previsão de atentado contra a segurança de serviço de utilidade pública ou o funcionamento de serviço de água, luz, força ou calor, ou qualquer outro de utilidade pública (art. 265), agravando-se a pena se o dano ocorrer em virtude de subtração de material essencial ao funcionamento dos serviços e de interrupção ou perturbação de serviço telegráfico ou telefônico (art. 266), com pena em dobro, se o crime é cometido por ocasião de calamidade pública.

Há comandos para proteger direitos como a saúde pública ou a moeda nacional e outros documentos públicos, como indicam os artigos 278, 289, 293, 297.

Porém o principal Título do Código Penal no trato do tema da proteção do patrimônio público é o de $\mathrm{n}^{\circ} \mathrm{XI}$ que menciona os crimes contra a administração pública e se faz relevante mencionar, ainda que de forma perfunctória:

Os primeiros apontam aqueles praticados por funcionário público contra a administração em geral (arts. 312 a 327) e os seguintes aqueles praticados por particulares contra a administração em geral (arts. 328 a 337).

Assim, temos:

Peculato (art. 312) em que se faz típico apropriar-se o funcionário público de dinheiro, valor ou qualquer outro bem móvel, público ou particular, de que tem a posse em razão do cargo, ou desviá-lo, em proveito próprio ou alheio ou mesmo se embora não tendo a posse do dinheiro, valor ou bem, o subtrai, ou concorre para que seja subtraído, em proveito próprio ou alheio, valendo-se de facilidade que lhe proporciona a qualidade de funcionário; constando que a reparação do dano, se precedente à sentença irrecorrível, extingue a punibilidade e se posterior, reduz de metade a pena imposta.

Também é crime inserir ou facilitar, o funcionário autorizado, a inserção de dados falsos, alterar ou excluir indevidamente dados corretos nos sistemas informatizados ou bancos de dados da Administração Pública com o fim de obter vantagem indevida para si ou para outrem ou para causar (incluído pela Lei $\mathrm{n}^{\circ}$ 9.983/2000, figurando o art. 313-A no CP) e modificar ou alterar, o funcionário, sistema de informações ou programa de informática sem autorização ou solicitação de autoridade competente, sendo que as penas 
são aumentadas de um terço até a metade se da modificação ou alteração resulta dano para a Administração Pública ou para o administrado.

Outras condutas puníveis são: extraviar livro oficial ou qualquer documento, de que tem a guarda em razão do cargo; sonegá-lo ou inutilizá-lo, total ou parcialmente (art. 314), dar às verbas ou rendas públicas aplicação diversa da estabelecida em lei (art. 215), exigir, para si ou para outrem, direta ou indiretamente, ainda que fora da função ou antes de assumi-la, mas em razão dela, vantagem indevida (conhecido por 'concussão, art. 316) e exigir imposto, taxa ou emolumento que sabe indevido, ou, quando devido, emprega na cobrança meio vexatório ou gravoso, que a lei não autoriza ou mesmo se o funcionário desvia, em proveito próprio ou de outrem, o que recebeu indevidamente para recolher aos cofres públicos.

Pune-se o ato de solicitar ou receber, para si ou para outrem, direta ou indiretamente, ainda que fora da função ou antes de assumi-la, mas em razão dela, vantagem indevida, ou aceitar promessa de tal vantagem (corrupção passiva, art. 317), enquanto que a pena é mais grave, se, em consequência da vantagem ou promessa, o funcionário retarda ou deixa de praticar qualquer ato de ofício ou o pratica infringindo dever funcional, mesmo que cedendo a pedido ou influência de outrem.

Da mesma forma, retardar ou deixar de praticar, indevidamente, ato de ofício, ou praticá-lo contra disposição expressa de lei, para satisfazer interesse ou sentimento pessoal (prevaricação, art. 319) é considerado crime, o que também acontece com funcionário público que deixar, por indulgência, de responsabilizar subordinado que cometeu infração no exercício do cargo ou, quando lhe falte competência, não levar o fato ao conhecimento da autoridade competente.

Pune-se (advocacia administrativa: art. 321) o ato de patrocinar, direta ou indiretamente, interesse privado perante a administração pública, valendo-se da qualidade de funcionário, sendo que a pena é maior se o interesse é ilegítimo e também a prática de violência, no exercício de função ou a pretexto de exercê-la.

É crime (art. 323) abandonar cargo público, fora dos casos permitidos em lei sendo a pena maior se do fato resulta prejuízo público ou se o fato ocorre em lugar 
compreendido na faixa de fronteira, assim como entrar no exercício de função pública antes de satisfeitas as exigências legais, ou continuar a exercê-la, sem autorização, depois de saber oficialmente que foi exonerado, removido, substituído ou suspenso o exercício funcional ilegalmente antecipado ou prolongado (art. 324).

Há previsão de se punir (art. 325) o funcionário público que revelar fato de que tem ciência em razão do cargo e que deva permanecer em segredo, ou facilitar-lhe a revelação ou ainda quem permite ou facilita, mediante atribuição, fornecimento e empréstimo de senha ou qualquer outra forma, o acesso de pessoas não autorizadas a sistemas de informações ou banco de dados da Administração Pública; se utiliza, indevidamente, do acesso restrito, sendo mais gravemente punida a conduta se da ação ou omissão resultar dano à Administração Pública ou a outrem.

O rol continua com o reconhecimento de que se deve dar proteção contra a conduta de devassar o sigilo de proposta de concorrência pública, ou proporcionar a terceiro o ensejo de devassá-lo (art. 326).

Para o Código Penal, reputa-se como funcionário público (art. 327) quem, embora transitoriamente ou sem remuneração, exerce cargo, emprego ou função pública e equipara-se a funcionário público quem exerce cargo, emprego ou função em entidade paraestatal, e quem trabalha para empresa prestadora de serviço contratada ou conveniada para a execução de atividade típica da Administração Pública. A pena de cada delito será sempre aumentada da terça parte quando os autores dos crimes previstos no correspondente Capítulo forem ocupantes de cargos em comissão ou de função de direção ou assessoramento de órgão da administração direta, sociedade de economia mista, empresa pública ou fundação instituída pelo poder público (tema incluído pela Lei $n^{\circ} 6.799$ de 1980).

Outras condutas criminalizadas são: usurpar o exercício de função pública (art. 328), agravada se o agente aufere vantagem; opor-se à execução de ato legal, mediante violência ou ameaça a funcionário competente para executá-lo ou a quem lhe esteja prestando auxílio (art. 329), sendo que mais grave se o ato, em razão da resistência, não se executa; desobedecer a ordem legal de funcionário público (art. 330); desacatar funcionário público no exercício da função ou em razão dela (art. 331); solicitar, exigir, cobrar ou 
obter, para si ou para outrem, vantagem ou promessa de vantagem, a pretexto de influir em ato praticado por funcionário público no exercício da função (art. 332), com aumento de pena se o agente alega ou insinua que a vantagem é também destinada ao funcionário.

Considera-se, também, para efeito da proteção da administração pública o ato de oferecer ou prometer vantagem indevida a funcionário público, para determiná-lo a praticar, omitir ou retardar ato de ofício (conhecida como corrupção ativa, art. 333), sendo a pena aumentada se, em razão da vantagem ou promessa, o funcionário retarda ou omite ato de ofício, ou o pratica infringindo dever funcional.

Há previsões de proteção do patrimônio frente à questão tributária, indicando-se a conduta de importar ou exportar mercadoria proibida ou iludir, no todo ou em parte, o pagamento de direito ou imposto devido pela entrada, pela saída ou pelo consumo de mercadoria (contrabando ou descaminho, art. 334), punindo-se, também quem pratica navegação de cabotagem, fora dos casos permitidos em lei; pratica fato assimilado, em lei especial, a contrabando ou descaminho; vende, expõe à venda, mantém em depósito ou, de qualquer forma, utiliza em proveito próprio ou alheio, no exercício de atividade comercial ou industrial, mercadoria de procedência estrangeira que introduziu clandestinamente no País ou importou fraudulentamente ou que sabe ser produto de introdução clandestina no território nacional ou de importação fraudulenta por parte de outrem; adquire, recebe ou oculta, em proveito próprio ou alheio, no exercício de atividade comercial ou industrial, mercadoria de procedência estrangeira, desacompanhada de documentação legal, ou acompanhada de documentos que sabe serem falsos. Equipara-se às atividades comerciais, para os efeitos do que foi descrito, qualquer forma de comércio irregular ou clandestino de mercadorias estrangeiras, inclusive o exercido em residências, enquanto que a pena aplica-se em dobro, se a conduta do contrabando acontecer em transporte aéreo.

Da mesma forma, é crime suprimir ou reduzir contribuição social previdenciária e qualquer acessório, mediante as seguintes condutas: I - omitir de folha de pagamento da empresa ou de documento de informações previsto pela legislação previdenciária segurados empregado, empresário, trabalhador avulso ou trabalhador autônomo ou a este equiparado que lhe prestem serviços; II - deixar de lançar mensalmente nos títulos próprios da contabilidade da empresa as quantias descontadas dos segurados ou 
as devidas pelo empregador ou pelo tomador de serviços; III - omitir, total ou parcialmente, receitas ou lucros auferidos, remunerações pagas ou creditadas e demais fatos geradores de contribuições sociais previdenciárias (art. 337-A). Entretanto, é extinta a punibilidade se o agente, espontaneamente, declara e confessa as contribuições, importâncias ou valores e presta as informações devidas à previdência social, na forma definida em lei ou regulamento, antes do início da ação fiscal, enquanto que é facultado ao juiz deixar de aplicar a pena ou aplicar somente a de multa se o agente for primário e de bons antecedentes, desde que o valor das contribuições devidas, inclusive acessórios, seja igual ou inferior àquele estabelecido pela previdência social, administrativamente, como sendo o mínimo para o ajuizamento de suas execuções fiscais. Por outro lado, se o empregador não é pessoa jurídica e sua folha de pagamento mensal não ultrapassa $R$ \$ 1.510,00 (um mil, quinhentos e dez reais), o juiz poderá reduzir a pena de um terço até a metade ou aplicar apenas a de multa, enquanto que tal valor será reajustado nas mesmas datas e nos mesmos índices do reajuste dos benefícios da previdência social.

Segue o rol vedando ao indivíduo impedir, perturbar ou fraudar concorrência pública ou venda em hasta pública, promovida pela administração federal, estadual ou municipal, ou por entidade paraestatal; afastar ou procurar afastar concorrente ou licitante, por meio de violência, grave ameaça, fraude ou oferecimento de vantagem (art. 335), punindo-se da mesma forma quem se abstém de concorrer ou licitar, em razão da vantagem oferecida.

É vedado, outrossim, rasgar ou, de qualquer forma, inutilizar ou conspurcar edital afixado por ordem de funcionário público; violar ou inutilizar selo ou sinal empregado, por determinação legal ou por ordem de funcionário público, para identificar ou cerrar qualquer objeto (art. 336); subtrair, ou inutilizar, total ou parcialmente, livro oficial, processo ou documento confiado à custódia de funcionário, em razão de ofício, ou de particular em serviço público (art. 337)

Em legislação própria (Lei $n^{\circ}$ 8.137/90) encontram-se outras previsões para proteção do patrimônio público no que tange aos delitos tributários e cita-se que constitui crime contra a ordem tributária suprimir ou reduzir tributo, ou contribuição social e qualquer acessório, omitindo informação, ou prestando declaração falsa às autoridades fazendárias; fraudando a fiscalização tributária, inserindo elementos inexatos, ou omitindo 
operação de qualquer natureza, em documento ou livro exigido pela lei fiscal; falsificando ou alterando nota fiscal, fatura, duplicata, nota de venda, ou qualquer outro documento relativo à operação tributável; elaborando, distribuindo, fornecendo, emitindo ou utilizando documento que saiba ou deva saber falso ou inexato.

Também se o contribuinte negar ou deixar de fornecer, quando obrigatório, nota fiscal ou documento equivalente, relativa a venda de mercadoria ou prestação de serviço, efetivamente realizada, ou fornecê-la em desacordo com a legislação; fazer declaração falsa ou omitir declaração sobre rendas, bens ou fatos, ou empregar outra fraude, para eximir-se, total ou parcialmente, de pagamento de tributo; deixar de recolher, no prazo legal, valor de tributo ou de contribuição social, descontado ou cobrado, na qualidade de sujeito passivo de obrigação e que deveria recolher aos cofres públicos; exigir, pagar ou receber, para si ou para o contribuinte beneficiário, qualquer percentagem sobre a parcela dedutível ou deduzida de imposto ou de contribuição como incentivo fiscal; deixar de aplicar, ou aplicar em desacordo com o estatuído, incentivo fiscal ou parcelas de imposto liberadas por órgão ou entidade de desenvolvimento e utilizar ou divulgar programa de processamento de dados que permita ao sujeito passivo da obrigação tributária possuir informação contábil diversa daquela que é, por lei, fornecida à Fazenda Pública.

Finalmente, pode ainda o Ministério Público considerar que há agrupamento de pessoas para violar o patrimônio público, se observado que se associaram mais de três pessoas, em quadrilha ou bando, para o fim de cometer crimes (art. 288 do CP), cuja pena será maior se a quadrilha ou bando for armado.

O tema não se esgota em tais artigos, sendo que a legislação é extensa e diferida, entretanto, estes apresentados são aqueles pertinentes para o cerne do combate aos danos causados ao patrimônio público (consideradas todas as modalidades apresentadas na classificação proposta, conforme o capítulo que se segue). 


\section{3 - Conclusão do Capítulo.}

Portanto, é certo afirmar que no cenário brasileiro atual, não só é admitida a necessidade de prestação de contas por parte do administrador público, como também o controle e a fiscalização de seus atos.

Neste contexto, a presença de instituições fortes indica que os rumos da atividade do serviço público, envolvendo tanto as movimentações financeiras, como o gerenciamento do patrimônio público, sejam aquelas voltadas para a sociedade, sejam aquelas afetas à existência do Estado em si mesmo, cada vez mais adotam caráter adequado aos anseios sociais, afastando-se máculas (propositais ou não) e pontuando caminhos de eficiência.

Os Tribunais de Contas e do Ministério Público, respectivamente, exercem seu papel e adquirem o respeito da sociedade e dos órgãos destinatários de sua atuação, permitindo que se reconheça sua importância enquanto agentes do processo de busca da harmonia social.

Segue, portanto, o trabalho com a discussão a respeito do conceito de 'patrimônio público', e que, propositadamente foi deixado para o final, uma vez que não se vislumbra qualquer dúvida quanto aos órgãos e meios de fiscalização até aqui analisados, nem quanto ao fato de que deve existir, por parte deles, o controle e a fiscalização sobre o patrimônio público, porém, de outra forma, na medida em que o mencionado conceito admite distintas óticas doutrinárias (como será visto) implica reconhecer que se for possível adotar um critério regular e abrangente, as ações fiscalizatórias estarão absolutamente adequadas em sua forma de integrar o processo de fiscalização, em especial aquela de cunho patrimonial na administração pública. 


\section{CAPÍTULO 5 - O PATRIMÔNIO PÚBLICO}

Realizado o estudo acerca da fiscalização e do controle da administração pública, bem como dos órgãos e entidades que devem deles se incumbir e ainda dos elementos para sua realização, resta verificar o tema do patrimônio público, propriamente dito, para que se possa situar sua fiscalização e controle específicos.

Falar em patrimônio público implica em avaliar, distinta e inicialmente, o que é 'patrimônio' e o que é 'público' para, em seguida, verificar a dimensão das expressões quando agregadas.

\section{1 - A expressão 'Patrimônio'.}

Apenas como referência preliminar, de natureza semântica, a palavra 'patrimônio' recebe diversas atribuições. Interessa-nos mencionar ${ }^{253}$ : “... 4. Fig. Riqueza: patrimônio moral, cultural, intelectual. 5. Dir. Complexo de bens, materiais ou não, direitos, ações, posse e tudo o mais que pertença a uma pessoa ou empresa e seja suscetível de apreciação econômica.

Também há sugestão de diversas abordagens para o vernáculo 'público'254. Logo as primeiras já dizem respeito ao interesse do presente trabalho: 1.Do, ou relativo, ou pertencente ou destinado ao povo, à coletividade: opinião pública; bem-estar público; movimento público. 2. Relativo ou pertencente ao governo de um país: repartição pública; cargo público. 3. Que é de uso de todos; comum; hospital público; passeio público. 4. Aberto a qualquer pessoa: ... concurso público.

Vê-se, assim que, na fonte linguística, a expressão 'patrimônio' mostra um vínculo de pertença existente entre a pessoa humana e um valor, seja material ou intelectual com determinada apreciação, enquanto que o vernáculo 'público' se associa à coletividade ou ao ente abstrato que existe para servi-la.

\footnotetext{
${ }^{253}$ FERREIRA, Aurélio Buarque de Holanda; Novo Dicionário Aurélio da Língua Portuguesa. Ed, Nova Fronteira, RJ, 1986, p.1282

${ }^{254}$ FERREIRA, Aurélio Buarque de Holanda; Novo Dicionário Aurélio da Língua Portuguesa. Ed, Nova Fronteira, RJ, 1986, p.1414
} 
Popularmente, a menção à palavra 'patrimônio' remete a uma associação, a um liame com propriedade, com riqueza, o que se compreende pelo histórico do Brasil cuja sociedade pode ser, sob determinada ótica, ao longo do tempo, classificada entre 'aqueles que têm' e 'os que não têm' - entretanto exige-se, como afirmado, uma conceituação mais ampla para efetivamente se inserir 'patrimônio' em sua real essência e abrangência no contexto social e jurídico.

Também para conceituação de patrimônio, oportuno mencionar a distinção entre os vocábulos bens e coisas, que são usados de forma indiferente em diversas oportunidades, inclusive em textos legais. Pode-se afirmar que coisa é gênero do qual bem é espécie. Aquela consiste em tudo que existe de forma objetiva, excepcionalizado o próprio homem. Assim, por exemplo, o sol, a lua, os animais etc. Já o bem traz consigo ideia de utilidade e quantidade, traduzindo-se em valor econômico ou alguma riqueza ${ }^{255}$.

Logo, na terminologia jurídica, bens são todas as coisas que, por se constituírem em objeto de fruição humana, representam uma utilidade, sendo susceptíveis de apropriação, incluindo dinheiros, direitos e obrigações. O patrimônio pode ser também, compreendido como tal conjunto de bens, constituindo uma unidade jurídica.

Neste sentido, há definições ${ }^{256}$ que não podem deixar de ser estudadas, também como ponto de partida de cunho vernacular.

"Patrimônio" que deriva do latim patrimonium, de pater, significa originariamente, no sentido que os romanos atribuíam (família pecunia - fragmento das XII Tábuas) 'bens da família' ou 'bens herdados dos pais'. Também o chamavam de res ou bona. Em sentido jurídico, seja civil, comercial ou em Direito Público, entende-se como 'conjunto de bens, de direitos, e obrigações aplicáveis economicamente, isto é, em dinheiro, pertencente a uma pessoa natural ou jurídica, constituindo uma universalidade'.

Assim considerado, constitui uma unidade jurídica, abstrata e distinta dos elementos materiais que o compõe, de modo que podem ser estes alterados, pela diminuição ou aumento, ou mesmo desaparecerem. Existe a ideia de que patrimônio está

\footnotetext{
${ }^{255}$ RODRIGUES, Silvio. Direito Civil. Vol1. Parte geral, $32^{\mathrm{a}}$ ed. São Paulo. Saraiva, 2002. P.116.
}

${ }^{256}$ DE PLÁCIDO E SILVA. Vocabulário Jurídico, $27^{\mathrm{a}}$ Ed., 2006, Rio de Janeiro: Ed. Forense. 
intimamente ligada à de pessoa, de modo a ser considerado como 'prolongamento da personalidade' (Raoul de La Grasserie).

Fernando Rodrigues Martins ${ }^{257}$ escreve: "Patrimônio, expressão em si considerada, revela a idéia do conjunto de bens e direitos de que seja titular determinada pessoa, podendo dele dispor nas modalidades previstas em lei. Tais bens podem ser de natureza móvel ou imóvel, na dimensão corpórea, ou seja, presos à categoria de 'direito das coisas', com também de natureza incorpórea, já que relacionados à prestação de fazer ou não fazer, como, no caso, a energia elétrica. Englobam ainda a noção de patrimônio os parâmetros afetos aos direitos, créditos e ações de qualquer pessoa. E, por fim, a idéia de patrimônio se aproxima, sem se confundir, dos atributos morais da pessoa humana”.

\section{2 - A expressão 'Público'.}

"Público" deriva do latim publicus formado de populicus, populos (povo, habitantes) e significa, em sentido geral, o que é comum, pertence a todos, é do povo, opondo-se ao privado mostrando que nem pertence nem se refere ao indivíduo ou ao particular.

Distinguindo o termo público, que é o que pertence a todo o povo considerado coletivamente, da expressão comum, para o que pertence ou se estende distributivamente ao povo ou a todos, considerados como indivíduos - aponta-se que podem coincidir, se as distintas qualidades se apresentarem no mesmo fato como no caso dos logradouros porque não pertencem a ninguém em particular, mas a todos que também participam de sua utilidade. Indica-se que publico na linguagem jurídica é tomado como na acepção de próprio ou pertinente ao Estado.

O termo revela a subordinação ou a afetação que incide sobre todas as coisas ou fatos, qualificados ou considerados como tal. Assim, no conceito de público integra-se o de autoridade do Estado ou poder do Estado, mostrando sua identificação com a própria coisa ou com o próprio fato, a que, intimamente, se ligou. Nessa razão não se refere simplesmente à condição de ser coisa de interesse comum ou de interesse coletivo,

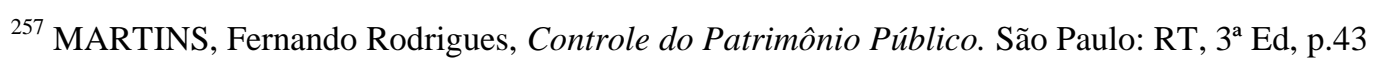


mas à íntima conexão ou a identificação da própria coisa com as finalidades do Estado, pairando acima dos interesses particulares e, mesmo, coletivos.

5.3 - A expressão "Patrimônio Público".

Assim posto, observa-se que amplo é o caminho sobre as implicações derivadas da definição de cada estrutura mencionada. Entretanto, quando colocados os termos em uníssono, ganham característica própria e individualizadas, mas, na verdade, ouso dizer, sem uma identidade absoluta, posto que a legislação e a doutrina apresentam distintos elementos em sua abordagem, gerando diferentes oportunidades de interpretação sobre seu significado.

Diante de sua diversidade, quando se verifica discrepância de terminologia e definição, com implicações jurídicas diversas, uma abordagem será aqui realizada sobre os diversos conceitos encontrados na doutrina, em especial porque se propõe uma sistematização quanto ao termo 'patrimônio público'.

Descreve-se, unindo os conceitos ${ }^{258}$, o Patrimônio Público como sendo “representado pelo conjunto de bens que pertencem ao domínio do Estado, e que se institui para atender a seus próprios objetivos ou para servir à produção de utilidades indispensáveis às necessidades coletivas".

Segundo o sitio eletrônico do Ministério Público Federal ${ }^{259}$, Patrimônio Público é o conjunto de bens que pertencem ao domínio do Estado e que se institui para atender a seus próprios objetivos ou para servir à produção de utilidades indispensáveis às necessidades coletivas.

Já na página eletrônica da Receita Federal ${ }^{260}$ encontramos como definição de Patrimônio Público o conjunto de bens, direitos e obrigações que se encontram à disposição do Município do Estado ou da União, para a realização dos seus fins.

${ }^{258}$ DE PLÁCIDO E SILVA. Vocabulário Jurídico, $27^{\mathrm{a}}$ Ed., 2006, Ed. Forense - Rio de Janeiro
${ }^{259}$ www.pgr.mpf.gov.br/servicos/glossario. Acesso em outubro de 2010.
http://leaozinho.receita.fazenda.gov.br/biblioteca/Glossario/default.htm\#P). Acesso em outubro de 2010. 
Seguindo as apresentações eletrônicas, o Tesouro Nacional ${ }^{261}$ aponta no portal da transparência que Patrimônio Público é o conjunto de bens à disposição da coletividade.

Outrossim, as Normas Brasileiras de Contabilidade fornecem um espectro mais específico do tema: ${ }^{262}$

Segundo aquelas Normas, Patrimônio Público é o conjunto de bens e direitos, tangíveis ou intangíveis, onerados ou não, adquiridos, formados ou mantidos com recursos públicos, integrantes do patrimônio de qualquer entidade pública ou de uso comum, que seja portador ou represente um fluxo de benefícios futuros inerentes à prestação de serviços públicos.

Sob o enfoque contábil é estruturado em Ativo, Passivo e Patrimônio Liquido, onde o Ativo compreende as disponibilidades, os bens e os direitos que possam gerar benefícios econômicos ou potencial de serviço; o Passivo compreende as obrigações, as contingências e as provisões; o Patrimônio Líquido representa a diferença entre o Ativo e o Passivo devendo ser evidenciado o resultado do exercício segregado dos resultados acumulados de exercícios anteriores.

Ainda a classificação dos elementos patrimoniais considera a segregação em circulante e não-circulante, com base em seus atributos de conversibilidade, exigibilidade e interesse social.

Os ativos são classificados como circulante quando satisfizerem um dos seguintes critérios: estarem disponíveis para utilização imediata; serem realizados ou terem a expectativa de realização, consumo ou venda até o final do exercício financeiro subseqüente. Já os outros ativos são classificados como não-circulante.

\footnotetext{
261 http://www.portaltransparencia.gov.br/glossario/DetalheGlossario.asp?letra=p. Acesso em outubro de 2010

${ }^{262}$ NBC T 16.2 - PATRIMÔNIO E SISTEMAS CONTÁBEIS. In.

http://www.tesouro.fazenda.gov.br/contabilidade_governamental/download/RES_CFC11292008_NBC_T162 Patrimonio\%20_Sistemas_Contabeis.pdf - acesso em 24/08/12
} 
Os passivos são classificados como circulante quando satisfizerem um dos seguintes critérios: corresponderem a valores exigíveis até o final do exercício financeiro subseqüente; corresponderem a valores de terceiros ou retenções em nome deles, quando a entidade pública for a fiel depositária. Os outros passivos são classificados como nãocirculante.

Por sua feita, a doutrina traz apresentações que merecem tópicos próprios:

“...patrimônio público é o conjunto de bens, valores, direitos (inclusive sociais e morais) e créditos pertencentes aos entes púbicos (União, Estados, Distrito Federal e Municípios), através da administração direta ou indireta e fundacional, cuja conservação seja de interesse público e difuso, estando não só os administradores, como também os administrados, vinculados à sua proteção e defesa. Tais elementos, mesmo sob a posse de particular, nunca perderão a qualidade de domínio público, dada sua origem: o ente público. Sempre lembrando que os bens públicos podem ter, ainda, natureza artística, histórica, estética e turística. ${ }^{263}$

Segundo este enfoque, a partir do art. $1^{\text {o }}$ da Lei Federal n $n^{\circ}$ 8.429/1992 (Lei de Improbidade Administrativa) o conceito de Patrimônio Público foi estendido para entidades que, embora não pertencentes à estrutura organizacional do Estado, ou sendo pessoa de direito privado, recebam qualquer tipo de auxílio do poder público.

Assim o Patrimônio Público não poderia ser compreendido apenas do ponto de vista material, econômico ou palpável, mas sim espelhar todo tipo de situação em que a Administração Pública estivesse envolvida, desde a mais módica prestação de serviço típica até os bens que fazem parte de seu acervo dominial, incluindo também elementos como a moralidade. Há proposta para que seja considerado um Direito Humano, tomando por referência a Declaração Universal dos Direitos do Homem e a Convenção Interamericana Contra a Corrupção, das quais o Brasil é signatário.

Afirma-se que a Constituição Federal, conforme art.70, parágrafo único (texto da Emenda n 19/1998), torna analítico o conceito de Patrimônio Público e a lógica

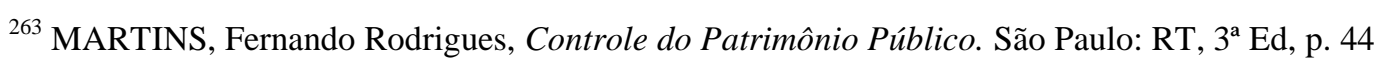


ali contida, por partes, permite a visualização da cada elemento sob um prisma sociológico (ser ou real) e também do ponto de vista jurídico, normativo (dever ser).

Aqui, entenda-se por sociológica a posição de Luis Recasens Siches ${ }^{264}$ que aponta que “...Encontramos el Estado formando parte de nuestra vida y nos encontramos nosotros formando parte Del Estado. Prácticamente nos referimos a él em innumeras ocasiones; no sentimos gravitar sobre nosotros, imponiéndonos múltiples y gravosas exigências; nos enrolamos, a veces a su servicio, com entusiasmo; otras, ló experimentamos como obstáculopara nuestros deseos; sabemos que sin él la vida nos sería imposible, o por ló menos muy difícil; pelo también, em ocasiones, llega a exigirnos el sacrifício de nuestra propia vida; em la medida que hacemos política, nos afanamos para conseguir que sea de um determinado modo; de uma parte, nos hallamos como ingredientes de él; de outra parte, ló consideramos como uma magnitud transindividual; jamás ló hemos percebido em su auténtico y total ser, pelo ló vemos actuando com manifestaciones varias, como actividad legislativa, como administración, como ejército, como polícia, como asistencia social, como tribunales de justisia; nos aparece simbolizado em um escudo, em uma bandera, em um himno; nos dirigimos a él pidiéndole que haga determinadas cosas; y también nos enfretamos com él demanda de que no haga, de que se abstenga, de que nos deje em liberdad de realizar nuestros quehaceres propios $e$ individuales, que no quisiéramos ver pertubados por su intervención”

E, portanto, para Martins ${ }^{265}$, a compreensão do Patrimônio Público seria abrangente e quase infinita, iniciando pelos instrumentos necessários ao Estado para alcançar seus fins, passando também pela ideia de propriedade coletiva, como ainda na concepção de bens institucionais ou bens obrigatoriamente sob proteção (fazer) e abstenção (não fazer), sendo, talvez importante visualizá-lo em sua concretude, ou seja, pelo caráter objetivo, como o próprio Estado, enquanto que sob a ótica normativa sendo um objeto de experiência ou produto obtido a partir de dados sensíveis externos (matéria), segundo as formas puras de conhecimento, onde no plano normativo cada elemento tem sua forma, seu conteúdo e suas características.

\footnotetext{
${ }^{264}$ SICHES, Luis Recasens, Tratado general de filosofia del derecho, Mèxico: Ed. Porrua, $3^{\text {a }}$ Ed. p.335.

${ }^{265}$ MARTINS, Fernando Rodrigues, Controle do Patrimônio Público. São Paulo: RT, $3^{\mathrm{a}}$ Ed. p. 124
} 
Trata esta última da realidade do dever-ser, que os alemães chamavam de sein ou sollen (sobre designar a realidade do que é do que deve ser, tal qual em Kelsen com tendência exclusivamente jurídica, inspirada no formalismo de Kant). ${ }^{266}$

Já Hugo Nigro Mazzilli ${ }^{267}$ citando a Constituição Federal, art. 5º inciso LXXIII; 20;26 e 216; Lei 4717/65, art.1 ${ }^{\circ}, \S 1^{\circ}$ e Lei $n^{\circ} 6938 / 81$, art.2 ${ }^{\circ}$, I., conceitua que ...Patrimônio Público é o conjunto de bens e direitos de valor econômico, artístico, estético, histórico, arqueológico ou turístico ou ainda de caráter ambiental.

Assim, o Patrimônio Público quando tomado em seu sentido estrito significaria o conjunto de bens e valores de caráter puramente econômico da Fazenda Pública (ex. crédito fiscal) e não representaria interesse transindividual (difuso, coletivo ou individual homogêneo). Então, se tomado no sentido lato englobaria estes últimos, sem excluir os primeiros.

Floriano de Azevedo Marques Neto ${ }^{268}$ explora o tema, confeccionando um histórico sobre a noção de Patrimônio Público, associando a expressão à construção do conceito de Estado, lembrando que na antiguidade, antes do surgimento das relações de propriedade, o que era necessário à existência humana se compartilhava entre os membros da sociedade e que, especialmente com o surgimento das cidades começou a se fazer presente uma esfera de bens distintos daqueles integrantes da propriedade individual.

Estabelece uma distinção entre 'bens' e coisas', sendo os primeiros os objetos que, com ou sem materialidade, (mesmo sem ser propriamente coisas) são dotados de utilidades suscetíveis de valoração econômica, enquanto que os últimos, no sentido jurídico, são tudo aquilo que pode ser objeto de relação jurídica, e no sentido não jurídico, os objetos dotados de materialidade.

Seriam três as dimensões de patrimonialidade: o patrimônio nacional (formado por todos os ativos que possuem valor para a coletividade no âmbito nacional, independentemente de pertencerem ou não ao domínio de entes públicos), o patrimônio

\footnotetext{
${ }^{266}$ BONAVIDES, Paulo. Ciência Política, São Paulo: Malheiros Editores, $17^{\mathrm{a}}$ Ed. p.40-44.

${ }^{267}$ MAZZILLI, Hugo Nigro. A defesa dos interesses difusos em juízo. São Paulo: Ed. Saraiva, $22^{\mathrm{a}}$ Ed. p.189

${ }^{268}$ MARQUES NETO, Floriano de Azevedo. Bens Públicos - Função Social e Exploração Econômica. O Regime Jurídico das Utilidades Públicas. Minas Gerais: Ed. Forum. 2009, Cap.1
} 
público (que corresponde a todos os ativos economicamente valoráveis - bens, direitos e receitas - integrantes do domínio dos entes públicos) e os bens públicos (objetos que tem valor econômico atribuíveis aos entes públicos, não incluídas as receitas públicas).

Há consideração de que, no Estado moderno, ao aspecto dominial foi agregado o aspecto finalístico do acervo de bens públicos, surgindo a ideia de apartação entre as esferas do público e do privado a partir da separação do patrimônio pessoal do Soberano do patrimônio comum de toda gente e da constrição da figura do Estado como ente dotado de personalidade jurídica própria, que assume, ainda, a posição de dono dos bens públicos.

Neste tópico menciona que do fato do Estado assumir tal posição deriva a dificuldade no âmbito do Direito Administrativo de se enfrentar a equiparação do Estado às demais pessoas físicas ou jurídicas no que tange à natureza dos direitos que possui.

Além da relação de domínio eminente estatal (entenda-se relação de autoridade, mediada pelo Direito, do poder público sobre o território) o Estado tem ainda com parcela dos bens situados no seu território uma relação de proprietário. Assim, os bens podem integrar o Patrimônio Público em função de sua natureza, de seu destino ou de uma relação jurídica que faz com que eles sejam transferidos para a titularidade de uma pessoa jurídica de direito público.

Também lembra que o processo de constituição do Patrimônio Público no Brasil foi peculiar, na medida em que a regra foi a apropriação privada de bens originalmente públicos e, no momento da constituição do Estado Nacional passaram a integrar o domínio nacional os bens remanescentes da apropriação privada (terras devolutas), sendo que não houve uma preocupação central de delimitar o que constituiria efetivamente o Patrimônio Público, de modo que o direito público não se debruçou sobre o tema como deveria, resultando tratamento pelo direito privado e sua respectiva ótica.

Indica, ainda, que existe relação de propriedade entre o Estado e o bem sobre todos os bens que integram o patrimônio público (seja pela lei civil ou pela necessidade de o Estado exercer direitos típicos de propriedade) e esta relação de 
propriedade é sempre condicionada às finalidades públicas que justificam ou obrigam a existência do domínio estatal que se sustenta no atingimento de uma função estatal.

Abordagem outra apresenta André de Vasconcelos Dias ${ }^{269}$ ao afirmar que há sinonímia entre os vocábulos 'público' e 'social' quando se trata de patrimônio público. Defende a ideia que não existe um interesse estatal de conteúdo autônomo, distinto do interesse público, e, portanto, o patrimônio público e o patrimônio social se equivalem.

Ao admitir que o conceito de patrimônio público está em gestação, mas tem como pressuposto o erário (que, entretanto não exaure o conceito daquele) refere divergência doutrinária entre a corrente que adota a tendência de extrair o conceito de patrimônio público daquela definição constante na Ação Popular ${ }^{270}$, ou seja constituiriam o patrimônio público "os bens e direitos de valor econômico, artístico e estético, histórico ou turístico", e que seria restritiva e outra mais próxima do art. 129, III da Constituição Federal quando remete ao Ministério Público a proteção do patrimônio público e social, do meio ambiente e outros interesses difusos e coletivos, esta mais abrangente.

Assim, na medida em que o patrimônio público está intimamente ligado ao interesse público, não se poderia precisar sua definição, fixando-se, entretanto diretrizes, tais como os princípios constitucionais da administração pública, dentre eles a moralidade administrativa.

Maria $\operatorname{Garcia}^{271}$, ao se referir ao patrimônio público comenta sobre a dificuldade do tema, tanto no direito administrativo, como no constitucional, justificandose nas próprias raízes na Nação brasileira, tocando na antiga legislação portuguesa, mantendo "o fascínio do passado, das origens".

Admitindo importância fundamental e sempre atual, dada a relação com a ordem econômica e financeira, assinala também ser o "patrimônio nacional, que se constitui no patrimônio do cidadão, como tal".

\footnotetext{
${ }^{269}$ in Boletim Científico da Escola Superior do Ministério Público, Ano 5, nºs 20/21, julho/dezembro 2006, Brasilia-DF.

${ }^{270}$ Como em: PAZZAGLINI FILHO, Marino; ROSA, Márcio Fernandes Elias e FAZZIO JR, Waldo. Improbidade Administrativa. $4^{\mathrm{a}}$ ed. São Paulo: Atlas, 1999, p.75

${ }^{271}$ In artigo Revista dos Tribunais, ano 7, n 27 , abril/junho 1999
} 
Hely Lopes Meirelles ${ }^{272}$ aponta que algumas coisas ou bens pertencem ao próprio Estado, outros, embora pertencentes a particulares, ficam sujeitos às limitações administrativas impostas pelo Estado; outros, finalmente, não pertencem a ninguém, por inapropriáveis na sua natureza, mas sua utilização subordina-se às normas estabelecidas pelo Estado. Esse conjunto de bens sujeitos ou mesmo pertencentes ao Estado, constitui o domínio público, em seus vários aspectos e admitindo que tal conceito de domínio público não é uniforme na doutrina, refere domínio público em sentido amplo e em seus desdobramentos: político (chamado domínio eminente) e jurídico (domínio patrimonial).

Assim, em sentido amplo, domínio público é o poder de dominação ou de regulamentação que o Estado exerce sobre os bens de seu patrimônio (bens públicos) ou sobre os bens do patrimônio privado (bens particulares de interesse público) ou sobre as coisas inapropriáveis individualmente, mas com fruição geral da coletividade.

Lucia Valle Figueiredo ${ }^{273}$ prefere chamar de bens públicos e não domínio público, embora entenda ser esta última expressão de sentido mais abrangente.

Ainda classificando o domínio, Maria $\operatorname{Garcia}^{274}$ se refere a dois tipos: domínio eminente e domínio patrimonial. O primeiro é o poder político pelo qual o Estado submete à sua vontade todas as coisas de seu território; é poder que o Estado exerce potencialmente sobre as pessoas e os bens que se encontram no seu território ${ }^{275}$. O domínio patrimonial do Estado sobre seus bens constitui direito de propriedade, mas direito de propriedade pública, sujeito, portanto, a regime administrativo especial ao qual se subordinam todos os bens das pessoas administrativas, assim considerados bens públicos.

Hely Lopes Meirelles ${ }^{276}$ esclarece que "esse poder superior (eminente) que o Estado mantém sobre todas as coisas existentes em seu território não se confunde com o direito de propriedade que o mesmo Estado exerce sobre as coisas que lhe pertencem, por aquisição civil ou administrativa (domínio patrimonial)”.

\footnotetext{
${ }^{272}$ MEIRELES, Hely Lopes. Direito administrativo brasileiro, RT, 1977, p.467 et seq.

${ }^{273}$ FIGUEIREDO, Lucia Vale. Curso de Direito Administrativo, São Paulo: Malheiros, 1994, p.340

${ }^{274}$ In artigo Revista dos Tribunais, ano 7, $\mathrm{n}^{\circ}$ 27, abril/junho 1999

275 Também em MEIRELLES, Hely Lopes. Direito administrativo brasileiro, RT, 1977, p.469

${ }^{276}$ MEIRELLES, Hely Lopes. Direito administrativo brasileiro, RT, 1977, p.469
} 
Para ele o patrimônio público está formado por bens de toda natureza e espécie que tenham interesse para a Administração e para a comunidade administrada. Esses bens recebem conceituação, classificação e destinação legal para sua correta administração, utilização e alienação, tendo por fim precípuo o interesse público.

Já Lucia Vale Figueiredo ${ }^{277}$ observa que são dadas como sinônimos as expressões bens públicos e patrimônio público e registra que bens públicos são todos aqueles, quer corpóreos, quer incorpóreos, portanto, imóveis, móveis, semoventes, créditos, direitos e ações que pertençam a qualquer título à União, aos Estados ou Municípios, respectivas autarquias e fundações de direito público.

Inclui os bens das estatais na categoria de bens públicos, afirmando que as sociedades de economia mista, as empresas públicas e as fundações governamentais, sendo entidades com personalidade jurídica de direito privado não teriam seu patrimônio confundido com o da Administração geradora, a entidade matriz (apesar de cláusula estatutária de reversão de seu patrimônio à entidade matriz em caso de extinção).

Entretanto, Hely Lopes Meirelles e Maria Garcia, defendem que são bens públicos com destinação especial e administração particular das instituições a que foram transferidos para consecução dos fins estatutários. A origem e natureza total ou predominante desses bens continuam públicas; sua destinação continua pública, tão somente confiando a uma entidade de personalidade privada, que os utilizará na forma da lei instituidora e do estatuto que a reger.

Latu sensu, para tais autores, é patrimônio público, tanto é que na extinção da entidade, reverte ao ente estatal que a criou e qualquer ato que o lese poderá ser invalidada por ação popular (Lei Federal no 4.717/65, art. $\left.1^{\circ}\right)^{278}$.

\footnotetext{
${ }^{277}$ FIGUEIREDO, Lucia Vale. Curso de Direito Administrativo, São Paulo: Malheiros, 1994, p.341

${ }^{278}$ Art. $1^{\circ}$ Qualquer cidadão será parte legítima para pleitear a anulação ou a declaração de nulidade de atos lesivos ao patrimônio da União, do Distrito Federal, dos Estados, dos Municípios, de entidades autárquicas, de sociedades de economia mista, de sociedades mútuas de seguro nas quais a União represente os segurados ausentes, de empresas públicas, de serviços sociais autônomos, de instituições ou fundações para cuja criação ou custeio o tesouro público haja concorrido ou concorra com mais de cinqüenta por cento do patrimônio ou da receita ânua, de empresas incorporadas ao patrimônio da União, do Distrito Federal, dos Estados e dos Municípios, e de quaisquer pessoas jurídicas ou entidades subvencionadas pelos cofres públicos.
} 
Luiz Sales do Nascimento ${ }^{279}$ em artigo intitulado "A legitimidade do Ministério Público para proteção do patrimônio público e social" menciona que a definição de patrimônio público não é facilmente encontrável na doutrina e que se faz necessário haurir o conceito pela análise do regime jurídico.

Assim, afirma que os civilistas, com alguma suscetibilidade se arriscam, partindo da definição do Código Civil, e lembra Silvio Rodrigues ${ }^{280}$ quando afirmava que coisa é tudo que existe objetivamente, com exclusão do homem, enquanto bens são coisas úteis e raras, suscetíveis de apropriação e com conteúdo econômico, além dos valores não corporificados em coisas, mas que também tem estimativa econômica (chamados bens incorpóreos).

Os bens corpóreos e os incorpóreos fazem parte do patrimônio de uma pessoa, sendo chamados de bens patrimoniais, indicando tanto a soma do ativo (patrimônio bruto), quando o conjunto do ativo com dedução do passivo que o grava (patrimônio líquido).

A partir de então infere que o patrimônio público é formado pelo conjunto dos bens públicos. Conforme o Código Civil são públicos os bens de domínio nacional pertencentes à União, aos Estados ou aos Municípios, estabelecendo que todos os outros são particulares, seja qual for a pessoa a que pertencerem.

Também discorda daquela doutrina que, afirma, em geral se vale da interpretação autêntica constante no art. $1^{\circ}$ da Lei de Ação Popular para conceituar patrimônio público. Para ele o direito privado encarregou-se de gizar o conceito de patrimônio público restringindo-o apenas àquele pertencente às pessoas políticas de direito público interno (art. 65 do Código Civil) ${ }^{281}$, época em que não existiam as paraestatais que, quando criadas estavam fora do âmbito do patrimônio público.

\footnotetext{
${ }^{279}$ BUZZO ALVES et al. Org. Funções Institucionais do Ministério Público,Saraiva, 2001

${ }^{280}$ RODRIGUES, Silvio. Direito civil, v.I. p.100

281 OBS - O texto foi confeccionado sob a vigência do antigo Código Civil, Lei $n^{\mathrm{o}} 3071$ de $1^{\mathrm{o}}$ de janeiro de 1916 que apontava: Art. 65. São públicos os bens do domínio nacional pertencentes à União, aos Estados, ou aos Municípios. Todos os outros são particulares, seja qual for a pessoa a que pertençam. Com a nova redação apresentada pela Lei $n^{\circ} 10.406$ de 10 de janeiro de 2002, temos: Art. 98. São públicos os bens do domínio nacional pertencentes às pessoas jurídicas de direito público interno; todos os outros são particulares, seja qual for a pessoa a que pertencerem. Art. 99. São bens públicos: I - os de uso comum do povo, tais como rios, mares, estradas, ruas e praças; II - os de uso especial, tais como edifícios ou terrenos
} 
Assim, diante da necessidade de que os entes cujo patrimônio também tivessem a participação do Estado fossem controlados pela sociedade, lhe pareceu acertada a ampliação do conceito pela Lei de Ação Popular, porém, não limitada a ela, porque segundo a Constituição Federal (art. 5º, inciso LXXIII) já há distinção entre patrimônio público e entidade de que o Estado participe, senão não indicaria distintos institutos.

Entidade de que o Estado participe são aquelas que exercem atividade imprópria do Poder Público, mas de interesse da sociedade, e sem integrar o Estado, razão pela qual seus bens não se amoldam ao art.65 do Código Civil. Na verdade integram um patrimônio que não é público nem particular, mas sim composto para perseguir um fim social desejável, mas não necessariamente próprio do Poder Público. Seria o chamado patrimônio social, que será objeto de discussão em posterior oportunidade.

Para Elival da Silva Ramos ${ }^{282}$, as expressões ‘patrimônio público' e 'bens públicos’ são sinônimas e não se pode, ainda, incluir os bens das entidades paraestatais como bens públicos.

Os bens públicos pressupõem sempre a titularidade de uma pessoa jurídica de direito público e as empresas públicas, fundações governamentais e sociedades de economia mista são entidades com personalidade de direito privado (art. 173. $\S 1^{\circ}$ da $\mathrm{CF}$ ) e que, embora muitos dos bens que a elas pertençam seja oriundos da Administração Centralizada, sendo usual a cláusula estatutária de reversão do patrimônio à entidade mãe em caso de extinção, fato é que enquanto existentes não confundem seu patrimônio com o da Administração-geradora.

Afirma que toda conceituação de bem patrimonial público ou de bem dominial público está vinculada a um determinado ordenamento jurídico e não há nem

destinados a serviço ou estabelecimento da administração federal, estadual, territorial ou municipal, inclusive os de suas autarquias; III - os dominicais, que constituem o patrimônio das pessoas jurídicas de direito público, como objeto de direito pessoal, ou real, de cada uma dessas entidades. Parágrafo único. Não dispondo a lei em contrário, consideram-se dominicais os bens pertencentes às pessoas jurídicas de direito público a que se tenha dado estrutura de direito privado.

${ }^{282}$ RAMOS, Elival da Silva, Aspectos gerais do patrimônio imobiliário do Poder Público. In Cadernos FUNDAP, no 17, São Paulo, 1989, p. 16/31. 
pode haver um conceito universal de bem público, refletindo, assim, as variações terminológicas exatamente a variedade dos regimes jurídicos a eles aplicáveis.

Conceitua o 'patrimônio público' como: “Bens públicos são todos aqueles, quer corpóreos, quer incorpóreos, portanto, imóveis, móveis, semoventes, créditos, direitos e ações, que pertençam a qualquer título, a União, Estados, Municípios, respectivas autarquias e fundações de direito público. Configuram esses bens o patrimônio público e se encontram sob o regime de direito público ${ }^{, 283}$.

Edmir Netto de Araújo ${ }^{284}$ lembra que o fato do Estado ter personalidade jurídica própria significa que é dotado de capacidade de adquirir direitos e contrair obrigações, sendo também que uma das características da personalidade é a possibilidade de se possuir patrimônio próprio.

Assim, indaga como tratar a matéria do 'patrimônio público' quando se sabe que a pessoa jurídica do Estado além dos direitos normais da personalidade e patrimônio próprios, ainda tem a seu encargo incumbências que extravasam seu próprio círculo patrimonial, necessitando cuidar de bens e interesses públicos que podem repercutir no patrimônio de seus administrados e também no de outros Estados. Também questiona se a expressão 'patrimônio público' seria o mesmo que propriedade do Poder Público ou domínio público.

Para buscar o entendimento mais próximo da realidade traça histórico e lembra que a ideia de que certos bens integram conjuntos patrimoniais que não idênticos aos particulares vem da época dos romanos.

Consideravam eles as res extra commercium, as res publicae (terras, por exemplo), que pertenciam ao povo romano, as res comunes (como portos, estuários, rios) e as res universitatis (como ruas, praças públicas e fóruns), sendo que dentre as res publicae ficavam fora do comércio aquelas destinadas ao uso do povo, ao lado de outras que, embora pertencendo ao povo, estavam no comércio (res in pecunia populi).

283 RAMOS, Elival da Silva, Aspectos gerais do patrimônio imobiliário do Poder Público. In Cadernos FUNDAP, n $^{\circ}$ 17, São Paulo, 1989, p.341.

${ }^{284}$ ARAÚJO, Edmir Netto de. Curso de Direito Administrativo. São Paulo: Saraiva. 2010, p.1120/1121 
À época da Idade Média os bens públicos conquistados ou herdados eram considerados de propriedade do Rei e não do povo, até que em momento posterior retornou-se à noção romana da propriedade do povo, com atribuição ao soberano do poder de polícia sobre os bens, fiscalizando seu uso pelo povo para impedir o abuso ${ }^{285}$.

Os juristas começaram a ensaiar uma estruturação da doutrina dos bens públicos no período dos monarcas da Europa, extraindo dos textos dos jurisconsultos dados e princípios. Duas eram as teorias, uma sustentando que o Príncipe era como que o sucessor do populus romanus, cabendo-lhe por isso, o domimium da res publica, pelo mesmo título com que competia ao povo e a segunda (interpretando com maior precisão os textos) que atribuía as coisas públicas ao povo, que poderia usá-la, sem privilégios, em condições de igualdade, cabendo ao monarca o exercício do poder de policia, fiscalizando o uso para impedir o abuso ${ }^{286}$.

Constata-se que a caracterização do patrimônio público não foi objeto de muita preocupação entre os juristas enquanto considerado como propriedade do monarca, e depois do Estado propriamente dito, como pode ser observado na História do Brasil.

Existiam bens que pertenciam ao Rei (reguengos, realengos, patrimônio real pessoal); bens da Coroa, esses também patrimônio real mas não pessoal, exceto, portanto, os realengos; bens fiscais (impostos, foros, confiscos, multas) pertencentes ao Estado, e os direitos régios (de conferir cargos, nomeações, receber impostos e contribuições etc.), nos termos das Ordenações do Reino. Foi no período do Brasil Império que se iniciou o tratamento constitucional do patrimônio público, tripartindo-se o domínio nacional em Domínio do Estado, Domínio da Coroa e Domínio Público.

Já no período republicano, antecedendo ao Código Civil, vislumbravam-se as ideias de domínio público (bens de uso comum, inalienáveis e imprescritíveis) e domínio do Estado (bens de uso especial e dominicais, estes alienáveis), para, então com a promulgação do Código em 1916 constar no art. 65 (depois confirmado pelos arts. 98 e 99

\footnotetext{
285 MAYER, Otto, Derecho administrativo alemán, apud ARAÚJO, Edmir Netto de. Curso de Direito Administrativo. São Paulo: Saraiva. 2010, p.1120

${ }^{286}$ CRETELLA JR, José. Tratado do domínio público, Rio de Janeiro, Forense, 1984, p.24-5,
} 
e incisos, do Código Civil de 2002) que são bens públicos os pertencentes às pessoas jurídicas de direito público interno (União, Estados, Distrito Federal, Territórios, Municípios, autarquias e demais entidades de caráter público criadas por lei, inclusive com estrutura de direito privado - art. 41 e parágrafo único), discriminando-se os bens de uso comum do povo (I - mares, rios, estradas, ruas e praças), bens de uso especial (II - tais como edifícios ou terrenos destinados a serviço ou estabelecimento da administração federal, estadual, territorial ou municipal, inclusive autarquias) e bens dominicais (III - que constituem o patrimônio das pessoas jurídicas de direito público, como objeto de direito pessoal, ou real, de cada uma dessas entidades).

Fato é que muita divergência doutrinária aconteceu quanto à conotação de tal divisão, e prefere-se dar aos dois primeiros tipos a qualificação de indisponíveis (bens do domínio público, dominiais, de uso comum do povo e bens do patrimônio indisponível que não são de uso comum, mas estão afetados a serviços ou a estabelecimentos públicos) e ao último a qualificação de patrimônio indisponível ou bens dominicais.

Observa-se que os vocábulos bens e coisas são utilizados indiferentemente por diversos escritores e às vezes pela própria legislação. José Roberto de Andrade Coutinho $^{287}$ ao reafirmar que coisa é gênero do qual bem é espécie e a diferença está no fato de que coisa é tudo que existe objetivamente, com exclusão do homem, a exemplo do sol, da lua e dos animais, enquanto que bem inclui na compreensão a ideia de utilidade e quantidade, o que se traduz em valor econômico ou riqueza, recorda a definição de De Placido e Silva (já mencionado no presente trabalho) sobre o conceito de patrimônio, quando aponta que os bens, na terminologia jurídica, são todas as coisas que, por constituírem objeto de fruição humana representam uma utilidade ou uma riqueza e são suscetíveis de apropriação, inclusive os dinheiros, direitos e obrigações; e a esse conjunto de bens, constituindo uma unidade jurídica, também na terminologia jurídica, é que se designa patrimônio.

A gestão dos bens ou do patrimônio da Administração Pública, com fundamento nas classificações que dividem os bens entre móveis e imóveis e entre bens consumíveis e não consumíveis, constantes dos Capítulos I do Código Civil de 1916 (arts.

${ }^{287}$ COUTINHO, José Roberto de Andrade, Gestão Patrimonial na Administração Pública. Rio de Janeiro: Lumen Juris, 2004, p.9-10. 
43-49 e 51) ou no novo Código Civil (arts. 79-84 e 86), bem como na experiência das entidades que integram a Administração Pública, considerando sobretudo as características desses bens, pode ser subdividida em gestão do patrimônio imobiliário, gestão do patrimônio mobiliário permanente e gestão do patrimônio mobiliário consumível, conhecido ainda por suprimentos.

Há uma indicação de que o 'patrimônio público' como expressão própria, seria distinta da 'patrimônio da administração pública'. Aquela com conotação mais abrangente, enquanto que esta seria parte daquela ${ }^{288}$.

Assim, verificamos com menção a alguns autores que perpassam o tema, que não há unanimidade na doutrina acerca da conceituação da expressão 'patrimônio público' e consequentemente sobre sua abrangência. Entretanto, é possível que seja extraído, mesmo da divergência, que não se afasta a necessidade da fiscalização sobre todo o 'patrimônio público', limitando, neste aspecto aquela divergência, a extensão de tal fiscalização.

5.4 - Proposta de Sistematização do Patrimônio Público.

Uma vez que se percebe profunda divergência doutrinária sobre o 'patrimônio público', resulta que sua fiscalização também estaria em terreno movediço, por óbvio. Necessário seria, então, que se aproximassem os conceitos mediante a busca de uma sistematização do tema para que o espectro de fiscalização também ficasse delimitado.

Neste sentido, arrisca-se tal proposição e isto porque vale dizer, a sinonímia entre patrimônio público e bem público ou ainda com patrimônio social ou patrimônio da administração pública ou a conceituação distinta dos institutos, seja na classificação oriunda do Código Civil, seja nos quesitos da titularidade, destinação, regime jurídico, responsabilidade por sua administração e gestão certamente enseja diferentes abordagens sobre as competências na seara do quesito fiscalização, importante instrumento para o exercício da cidadania.

288 A polêmica será dirimida no derradeiro Capítulo quando da conclusão. 
Assim, considerando que ordenar as coisas pressupõe uma finalidade, e visando estabelecer a possibilidade de um mapeamento com indicação para os entes fiscalizadores acerca do espectro de sua atuação frente aos parâmetros traçados na Constituição Federal, propõe-se uma classificação didática sobre o Patrimônio Público ${ }^{289}$.

\section{1 - Patrimônio Público Próprio}

a) Primário - imobiliário, mobiliário permanente e consumível ou suprimentos, quer corpóreos, quer incorpóreos, portanto, imóveis, móveis, semoventes, créditos, direitos, ações, rendas e dinheiros, que pertençam a qualquer título à União, aos Estados ou Municípios (Poder Executivo) e ainda aos Poderes Judiciário, Legislativo e ao Ministério Público e ao Tribunal de Contas (enquanto órgãos da administração direta);

b) Secundário - imobiliário, mobiliário permanente e consumível ou suprimentos, quer corpóreos, quer incorpóreos, portanto, imóveis, móveis, semoventes, créditos, direitos, ações, rendas e dinheiros, que pertençam aos órgãos da administração indireta da União, dos Estados ou Municípios e a órgãos de controle tais como Conselho Nacional de Justiça, Conselho Nacional do Ministério Público e agências reguladoras;

Todos susceptíveis de fiscalização contábil, financeira, orçamentária, operacional e patrimonial propriamente dita, frente aos parâmetros da legalidade, legitimidade, economicidade, aplicação de subvenções e renúncia de receitas, diante da dualidade do controle externo/interno.

\footnotetext{
${ }^{289}$ Embora com cautela, porque como ensina Floriano de Azevedo Marques Neto in MARQUES NETO, Floriano de Azevedo. Bens Públicos - Função Social e Exploração Econômica. O Regime Jurídico das Utilidades Públicas. Minas Gerais: Ed. Forum. 2009. P.128, a taxonomia jurídica é sempre uma atividade perigosa, afinal é possível classificar os conceitos jurídicos a partir de infinitos critérios, agrupando-os e os desagrupando da mais variadas formas, todas com seu grau de acerto.
} 


\section{2 - Patrimônio Público Impróprio}

a) Social - o conjunto de bens jurídicos, como os direitos fundamentais, concebidos em face dos valores adotados pela Constituição Federal, tais como moralidade administrativa, proteção dos idosos, crianças, adolescentes, meio ambiente, urbanismo etc. além dos bens respectivos a tais direitos, como os de natureza cultural, estético, artístico, histórico, préhistórico, paisagístico, genético, turístico etc.

b) Diferido - para alocar bens jurídicos sob tutela de entidade de que o Estado não participe e que exerça atividade própria ou imprópria do Poder Público, mas de interesse da sociedade, e sem integrar o Estado, mas de seu interesse e composto para perseguir um fim social desejável, em especial aqueles objeto de terceirização ao particular.

Estes, impróprios são susceptíveis de controle por meio de procedimentos administrativos (tais como inquéritos civis), de ações civis públicas, ações populares, mandados de segurança etc. (estes últimos, via de regra, com provocação do Poder Judiciário, pelo cidadão ou ainda outros entes legitimados para tanto) e também pelas agências reguladoras ${ }^{290}$.

Diante de tal classificação poder-se-á indicar distintos espectros de atuação dos órgãos incumbidos da fiscalização, seja no sentido latu, seja no strictu, vale dizer, desde os primeiros movimentos fiscalizatórios que incumbem a uma chefia de uma repartição, passando pela atuação dos Tribunais de Contas, até a intervenção do Poder Judiciário, quando provocado no controle da legalidade, lembrando que não somente se verificam questões de compra e alienação patrimonial, mas também de sua utilização

290 Conforme o sítio eletrônico do Governo brasileiro (http://www.brasil.gov.br/sobre/obrasil/estrutura/agencias-reguladoras, acesso em 18/10/12), as agências reguladoras foram criadas para fiscalizar a prestação de serviços públicos praticados pela iniciativa privada. Além de controlar a qualidade na prestação do serviço, estabelecem regras para o setor. Atualmente, existem dez agências reguladoras, implantadas entre dezembro de 1996 e setembro de 2001, mas nem todas realizam atividades de fiscalização. Assim, se fiscalizam e criam regras, importa admitir que exercem aspecto de controle sobre ações privadas de interesse da sociedade, aqui inseridas conceitualmente no tema do patrimônio público. Por serem pessoas jurídicas de direito público (autarquias) são também objeto de fiscalização e seu patrimônio é dito 'próprio secundário'. 
diante da finalidade de gestão da administração pública ou ainda do respeito aos bens jurídicos que importam à sociedade.

Também, conforme a alocação estabelecida no sistema proposto, com a fiscalização acontecendo nos distintos momentos, a saber: anterior, concomitante e posterior aos atos praticados pelo administrador público em sua respectiva esfera de competência, e ainda por distintas entidades, seja o Tribunal de Contas, o Ministério Público, a Defensoria Pública, as Controladorias e ainda outros entes públicos ou mesmo os cidadãos individualmente considerados.

Observe-se, ao contrário do que entendem alguns, que deve se chamar a atenção para a distinção entre patrimônio público e bens públicos. Com a devida venia daqueles que pensam de forma distinta, estes últimos, na verdade são pertencentes a uma das categorias que se inserem na expressão Patrimônio Público. Esta expressão é muito mais abrangente e os bens nela estão contidos em uma ordem específica.

Faça-se constar que determinado 'patrimônio' pode estar em mais de uma das classificações, devendo ser analisado conforme o enfoque que se adote e a afetação dada ao bem ou ao direito ${ }^{291}$, embora a colocação distinta implique em reconhecer que estará modificada a forma que se estabelece para o controle.

Coloca-se como exemplo para esclarecer tal afirmação a biblioteca de uma Faculdade pertencente ao poder público. Suponha-se que o diretor decida por proibir definitivamente o acesso para consultas alegando que os livros estão em condições inadequadas e que podem sofrer deterioração e que, doravante serão apenas peças para exposição sem consulta. Em um primeiro momento vislumbra-se, no sistema de autocontrole, a proteção do patrimônio público próprio secundário (os livros, considerados

\footnotetext{
${ }^{291}$ Floriano Azevedo Marques (MARQUES NETO, Floriano de Azevedo. Bens Públicos - Função Social e Exploração Econômica. O Regime Jurídico das Utilidades Públicas. Minas Gerais: Ed. Forum. 2009. P.122123) aponta que há bens públicos que trazem uma afetação imanente, não por lhe ser inerente, mas por ser o próprio bem a individualização de um dado uso que, pela sua aplicação ao interesse coletivo, é tornado autônomo em relação ao bem que lhe dá suporte. Assim, refere o potencial de energia hidráulica elevado à condição de bem público da União conforme art. 20, VIII da CF. O curso d'água em que se localiza o potencial está intrinsecamente afetado a este uso, pois o bem hídrico segue um regime de propriedade autônomo e pode ser empregado em outras utilidades, mas o uso na geração de energia, que decorre das condições hidrológicas, constitui-se como bem autônomo correspondente ao isolamento do seu valor de uso. Iguala a referência ao patrimônio genético, sítios arqueológicos, pré-históricos e ainda jazidas de petróleo.
} 
bens corpóreos), porém ao mesmo tempo a violação do direito de acesso às informações neles contidas (maculando o patrimônio público social). A atitude do dirigente na proteção do bem em sí pode ser discutida por ação perante o Poder Judiciário, diante da mácula a um direito. Assim, os livros, na situação posta estão adequados em mais de uma classificação, uma se considerados em si mesmos e outra quanto à finalidade. Ao mesmo tempo em que se pode afirmar que a fiscalização do patrimônio (em se referido como bem) foi realizada, também se afirma que o direito que tal patrimônio representa (as informações, vedadas à consulta) poderá ser objeto de questionamento diante do controle social (por qualquer interessado).

No mesmo exemplo, se ao invés de proibição, fosse decidida uma mudança de local para outro considerado mais salubre para a vida útil dos livros, porém sem licitação ou processo de dispensa ou inexigibilidade (visando contratar empresa especializada), certamente a fiscalização aconteceria tanto para a verificação quanto ao procedimento administrativo da mudança (envolvendo o Tribunal de Contas e/ou o Ministério Público), quanto à essência do cuidado dispensado para com os livros além do tempo em que ficariam indisponíveis para consulta.

Especificamente, quando se fala de bens públicos (aqui considerados como patrimônio público próprio), Floriano Azevedo Marques ${ }^{292}$ expõe um extenso panorama sobre o regime jurídico aplicável a eles, e refere que não se limita o tema à verificação dos aspectos da inalienabilidade, impenhorabilidade, não oneração e imprescritibilidade (que seriam atributos dos bens públicos afetos à sua gestão), mas também com abordagem ampliada para que sejam verificados os aspectos próprios ao regime de direito público na aquisição, gestão e disposição deles.

Menciona que na aquisição, o Estado dispõe, além dos instrumentos gerais do direito civil, de instrumentos exorbitantes, próprios do regime publicístico; na alienação, existem restrições e condições para que o poder público disponha de seus bens e na gestão (que não pode ser confundida com mero uso dos bens) aplicam-se os princípios peculiares do direito público (e já vistos no presente trabalho). Refere o jurista que não existe um único regime jurídico de direito público aplicável a todos os bens e que existem

${ }^{292}$ MARQUES NETO, Floriano de Azevedo. Bens Públicos - Função Social e Exploração Econômica. O Regime Jurídico das Utilidades Públicas. Minas Gerais: Ed. Forum. 2009, p. 248 - 
vários matizes que irão variar conforme o tipo de bem, sua essencialidade, seu domínio ou a espécie de uso ao qual ele é afetado.

O tema é longo, porém é possível se afirmar, para o escopo deste trabalho, que, independentemente do regime jurídico a ser aplicado, há unificação no que tange à certeza de que deverão os bens públicos, em si mesmos ou em seus aspectos de aquisição, gestão e disposição, se submeterem à fiscalização nos termos em que aqui propostos.

Como exemplo, um imóvel (edifício de gabinetes de uma Secretaria de Estado), enquanto patrimônio próprio se submete à fiscalização contábil, financeira, orçamentária, operacional e patrimonial propriamente dita, frente aos parâmetros da legalidade, legitimidade, economicidade, aplicação de subvenções e renúncia de receitas, diante da dualidade do controle externo/interno e sua gestão e disposição, se submete, dentre outros, à moralidade (enquanto patrimônio público impróprio), sendo em tal aspecto susceptível de controle por meio de procedimentos administrativos (como inquéritos civis), ou ações civis públicas, ações populares etc.

Uma empresa com capital privado que participe de licitação para tratar o lixo de uma cidade, ou que tenha sido escolhida para o mesmo trabalho por deter exclusividade no mercado, tem seus bens (escavadeiras, empilhadeiras, prédios etc) sob sua exclusiva responsabilidade e este patrimônio não se submete ao sistema de controle e fiscalização patrimonial da administração pública. Entretanto, tanto o processo de licitação (ou sua dispensa ou inexigibilidade), como também o escopo do trabalho, devem respeito a tal sistema. Aqui nota-se proteção ao patrimônio público impróprio chamado Social, diante do direito constitucional ao meio ambiente sadio e também proteção à legalidade frente ao processo que tratou da contratação da empresa (que se enquadra na classificação junto ao Patrimônio Público Impróprio Diferido, por estar exercendo atividade de interesse da sociedade, sem integrar o Estado ou ser integrada por ele, em atividade própria daquele). ${ }^{293}$

\footnotetext{
${ }^{293}$ Hely Lopes Meirelles: In Direito Administrativo Brasileiro, 20ª edição, Malheiros Editores, São Paulo, 1995, pág. 296 indica que “Serviços próprios do Estado: são aqueles que se relacionam intimamente com as atribuições do Poder Público (segurança, polícia, higiene e saúde públicas, etc.) e para a execução dos quais a Administração usa da sua supremacia sobre os administrados. Por esta razão, só devem ser prestados por órgãos ou entidades públicas, sem delegação a particulares. Tais serviços, por sua essencialidade, geralmente são gratuitos ou de baixa remuneração, para que fiquem ao alcance de todos os membros da coletividade. Serviços impróprios do Estado: são os que não afetam substancialmente as necessidades da comunidade, mas satisfazem interesses comuns de seus membros, e, por isso, a Administração os presta remuneradamente, por seus órgãos ou entidades descentralizadas (autarquia,
} 
A Constituição Federal no art. 175 diz que incumbe ao Poder Público, na forma da lei, diretamente ou sob regime de concessão ou permissão, sempre através de licitação, a prestação de serviços públicos, e no parágrafo único indica que a lei disporá sobre: I - o regime das empresas concessionárias e permissionárias de serviços públicos, o caráter especial de seu contrato e de sua prorrogação, bem como as condições de caducidade, fiscalização e rescisão da concessão ou permissão; II - os direitos dos usuários; III - política tarifária; IV - a obrigação de manter serviço adequado.

Portanto, também o tema da concessão ou permissão do serviço público deve ser mencionado para efeito da fiscalização do patrimônio público. Fenômeno decorrente da incapacidade do Estado em prestar todos os serviços a ele afetos, indica que o particular, sob determinadas condições, teria como prestar alguns daqueles serviços, por meio de transferência de sua gestão. As prestadoras de serviços públicos, embora com personalidade jurídica de Direito Privado, estão sujeitas às regras e princípios do Direito Público, logo, devem se subsumir ao sistema de prestação de contas, controle e fiscalização.

Diante da natureza privada, o patrimônio próprio não pode ser fiscalizado tanto quanto o de um ente público (administração direta ou indireta). Assim, sua gestão contábil, financeira, orçamentária, operacional e patrimonial ficará sob responsabilidade de seus dirigentes, até porque existe o intuito de lucro financeiro embutido na atividade e direcionado em prol de seus titulares.

Porém o serviço prestado é em favor da sociedade, vale dizer, o bem jurídico é composto para perseguir um fim social desejável, o que implica em reconhecer que deve respeito aos princípios constitucionais, em especial da legalidade e da moralidade, além de eficiência ${ }^{294}$. Portanto, está adequado à classificação de patrimônio

empresas públicas, sociedades de economia mista, fundações governamentais), ou delega sua prestação a concessionários, permissionários ou autorizatários. Esses serviços normalmente são rentáveis e podem ser realizados com ou sem privilégio (não confundir com monopólio), mas sempre sob regulamentação e controle do Poder Público competente.". Na prática, observa-se que o Poder Público cada vez mais delega atividades próprias à administração indireta e até mesmo ao particular.

${ }^{294}$ Sobre concessionárias de serviço público, Cármen Lúcia Antunes Rocha, (in: ROCHA, Cármen Lúcia Antunes. Estudo sobre Concessão e Permissão de Serviço Público no Direito Brasileiro. São Paulo: Saraiva, 1996, p. 12) diz: "Serviço adequado é o que satisfaz as condições de regularidade, continuidade, eficiência, segurança, atualidade, generalidade, cortesia na sua prestação e modicidade das tarifas”. Desta forma, o 
público impróprio diferido, susceptível de controle por meio de procedimentos tais como inquéritos civis (do Ministério Público), ações civis públicas, ações populares, mandados de segurança, ações de agências reguladoras etc.

Um sítio arqueológico ou um ícone turístico é certo que devem receber a devida proteção do Estado, responsável por sua manutenção e gerenciamento. O bem físico, seja o terreno em que há o trabalho dos arqueólogos ou a praça em que o monumento se encontra para visitação pública, não será registrado pela contabilidade e nem existe para a finalidade do funcionamento da administração pública. Entretanto, estão adequados ao conceito de patrimônio público impróprio social, posto que representam bens jurídicos previstos na Constituição Federal (patrimônio arqueológico e turístico, respectivamente). À administração pública incumbe sua correta conservação e uso. Já o controle acontece se descumprido aquele ônus do administrador, sendo posterior e calcado em situação fática derivada de inação, podendo ele sofrer sanções caso permita que interferências temporais ou de ausência de segurança física resultem em danos a tal patrimônio, por exemplo. Se o particular assumir, por qualquer razão (até mesmo de 'marketing' da empresa) a gestão daquele patrimônio, assume, concomitantemente o ônus que seria do administrador público.

Já o petróleo é bem da natureza e pertence à União ${ }^{295}$ e sua prospecção depende que seu titular assim o permita. As empresas responsáveis pelo serviço terão que

prestador de serviços públicos, com personalidade jurídica de Direito Privado ou Público, deve: 1- Prestar os serviços regularmente, sem "altos e baixos”, mesmo que, por vezes, tenha que suportar condições negativas.2- Oferecer de forma ininterrupta os serviços que tenham esta natureza, não podendo suspendê-los abruptamente. 3- Ser eficiente no que diz respeito à qualidade do serviço, observando os padrões de atualização e modernização de seu setor. 4- Zelar pela segurança na prestação do serviço, de forma que não acarrete riscos materiais e morais à população. 5- Adaptar-se no tempo certo aos avanços da tecnologia. 6Observar o caráter geral da oferta do serviço, de forma a não beneficiar alguns em detrimento de outros.

7- Respeitar o consumidor e tratá-lo de forma cortês. A cortesia, apesar de ser característica puramente subjetiva, é considerada pelo senso comum como parte do serviço prestado, deixando de objetivar apenas o lucro e visando a humanização. 8- Praticar preços acessíveis, ou seja, deve-se levar em conta a capacidade financeira do cidadão comum para suportar o pagamento das tarifas impostas a ele.

${ }^{295}$ No Brasil, o petróleo pertence à União, embora a Lei 9 478/1997 garanta que, após extraído, a posse do petróleo passa a ser da empresa que realiza a extração deste recurso natural, mediante o pagamento dos royalties ao governo. Neste caso, tanto a união divide estes royalties entre o Governo Federal, Estados e Municípios onde ocorre a extração de petróleo localizado no subsolo destas unidades da Federação. A lei $n^{\circ}$ 9.478 reafirma o monopólio estatal do petróleo da União nas atividades relacionadas à exploração, produção, refino e transporte do petróleo no Brasil, mas também passa a permitir que, além da Petrobrás, outras empresas constituídas sob as leis brasileiras e com sede no Brasil passem a atuar em todos os elos da cadeia do petróleo, ou seja, do poço ao posto (em inglês, from well to wheel), em regime de concessão ou mediante autorização do poder concedente, a União. Até o advento desta lei, outras empresas só podiam atuar no downstream isto é, apenas na venda dos derivados do petróleo. A Petrobras perdeu, assim, o monopólio da 
se utilizar de equipamentos. Assim, se a empresa for particular e tiver vencido licitação, os equipamentos são seus e não se submetem a controle pela administração pública, embora o serviço prestado e tudo que se refira a ele deverá respeitar as regras de fiscalização, visto que há necessidade de um cuidado especial com o tema do meio ambiente. Porém se a exploração acontecer por meio de empresa da administração pública indireta, não somente o serviço, mas também o equipamento, a mão de obra e os dinheiros empregados deverão se submeter à fiscalização. Temos referência tanto ao patrimônio público próprio secundário como ao impróprio diferido.

Pode-se, afirmar, portanto, que a prática diuturna dos operadores do direito permite que sejam encontrados infindáveis e noveis exemplos sobre o tema do patrimônio público, servindo estes mencionados como ponto de referência para avaliação e discussão acerca do formato de sua referência legal e respectivo enquadramento no sistema de fiscalização, diante da sistemática proposta.

exploração e do refino de petróleo no Brasil. A mesma lei instituiu o Conselho Nacional de Política Energética (CNPE), órgão de assessoria e consulta da Presidência da República, com a atribuição de propor políticas para o setor petrolífero e a Agência Nacional do Petróleo (ANP), órgão regulador da indústria do petróleo e responsável pela definição de diretrizes para a participação do setor privado na pesquisa, exploração, refino, exportação e importação de petróleo e derivados. Posteriormente, diante da descoberta de jazimentos de petróleo e gás na camada pré-sal, ao longo do litoral brasileiro, a Lei $\mathrm{n}^{\circ} 9.478$ foi modificada pela Lei $n^{\circ} 12.351$, de 22 de dezembro de 2010. Atualmente, está em discussão a mudança no sistema de distribuição dos royalties do petróleo no Brasil, com a votação de nova disciplina para regulamentar o tema. In. http://cpdoc.fgv.br/producao/dossies/FatosImagens/PetrobrasAutoSuficiencia acesso em 16/11/2012. 


\section{CAPÍTULO 6 - CONSIDERAÇÕES FINAIS. CONCLUSÃO}

Neste capítulo derradeiro, busca-se uma conclusão, admitindo-se desde logo que o tema pode não ter sido esgotado, como provavelmente não o foi, diante da amplitude e da não unanimidade doutrinária quanto às expressões trabalhadas, e até porque é preciso ter em mente que a busca de uma sociedade melhor e mais justa passa pela oportunidade do correto gerenciamento dos escassos recursos à disposição do ente detentor do Poder e que este deve se submeter ao complexo sistema de fiscalização para que erros, desvios e abusos não aconteçam em seu mistér. Também para que se possa obter notas de crescimento no processo de gerenciar o patrimônio público e o trabalhar de ideias, ainda que distintas e por vezes conflitantes, quando então se admite que o aprendizado derivado do embate deve ser, a todo tempo, bem acolhido.

Assim, em derradeira provocação, é possível extrair do que foi dito que pode acontecer confusão entre as expressões 'fiscalização do patrimônio público' e 'fiscalização patrimonial da administração pública'. Entretanto elas não se excluem embora apresentem tênue diferença e a confusão seja absolutamente escusável, visto que o legislador não fixou definições claras e o próprio conceito de patrimônio público é volátil, conforme a interpretação doutrinária que se perfile, como visto.

Em realidade uma delas está contida na outra, vale dizer, fiscalizar o patrimônio público certamente contém o tema da fiscalização patrimonial da administração pública, posto que a primeira expressão adota significado mais abrangente, sendo certo que o estudo da forma e dos limites de atuação dos órgãos fiscalizadores coincide, no aspecto jurídico, tanto para o macrouniverso do patrimônio público como para a específica fiscalização patrimonial da administração pública.

Enquanto aquela expressão mais abrangente tem escopo de direito administrativo esta mais específica cuida de aspecto de direito financeiro, uma vez que mais próxima do tema orçamentário, e o estudo de uma implica necessariamente no da outra para que se adote a adequada compreensão tanto quanto aos aspectos coincidentes como aos divergentes. 
Significa, por exemplo, que o meio ambiente é reconhecido como integrante do patrimônio público e deve se submeter ao sistema fiscalizatório, porém em um primeiro momento sob aspecto distinto daquele de orçamento público (sua proteção perpassa pelo respeito às normas que regem os movimentos físicos ambientais), ao contrário da conservação de um imóvel de uma prefeitura que exige o estudo do aspecto financeiro para sua preservação. Ainda que em um segundo momento, admita-se que deverá o orçamento (ou quem dele se vale) se preocupar com a preservação ambiental.

A atuação dos órgãos e entes fiscalizadores, da forma que aqui estudados, tanto para o meio ambiente como para o prédio da prefeitura está classificada na 'fiscalização do patrimônio público', porém apenas aquela relativa ao edifício está no tópico da 'fisscalização patrimonial da administração pública'.

Entende-se, portanto, que o aspecto 'patrimonial' referido no art. 70 da Constituição Federal está intimamente ligado com os bens passíveis de registro contábil e na classificação proposta no presente trabalho (Capítulo 5) adequada ao Patrimônio Público Próprio, seja Primário, seja Secundário.

Recordando que o Estado opera principalmente pelo poder de imposição e que arrecada dinheiros no seio da sociedade tanto para sua própria manutenção como para o exercício da função para a qual existe é certo que determinados bens estarão voltados para sua existência, enquanto ente abstrato, e outros para a consecução de sua finalidade. Este conjunto de bens forma uma massa que deve ser administrada e conservada, formando o patrimônio do ente político.

É evidente que o Estado se justifica existir em função única de sua finalidade, então se pensado assim, mesmo os próprios que servem para seu funcionamento e que abrigam funcionários, estariam classificados como voltados para o atendimento das necessidades sociais. Porém, há que se estabelecer distinção e sob este aspecto a divisão, então, deve acontecer para que se possa fixar o espaço de atuação dos entes fiscalizadores quando verificam o correto manejo do patrimônio, seja o fixado para o funcionamento dos entes que integram o Estado, seja daquele que deve servir de instrumento para a realização das políticas públicas voltadas à sociedade. 
Assim, resumidamente, necessita o Estado de dinheiros e bens para que funcione e exerça sua função e necessita a sociedade de instrumentos para que aqueles bens e dinheiros estejam sempre corretamente administrados, tanto sob aspecto jurídico como finalístico.

Adolfo Atchabaian ${ }^{296}$ afirma que a gestão administrativa do Estado acontece em duas grandes esferas, a gestão financeira e a gestão patrimonial, onde “...La primera tiene por objeto reunir médios monetários y aplicarlos al pago de los gastos públicos; el elemento material manejado em esta gestión es el dinero, obtenido delos particulares por intemedio de la imposición, o del usufructo de algunos bienes del patrimônio privado del Estado. La gestión patrimonial se ocupa de lós bienes de posesión estática; tiende a la conservación de esos elementos, em el sentido físico y en el jurídico, y lós utiliza em La prestación de lós servicios públicos, ua em forma de instrumentos materiales de esos servicios, ya como fuentes de entradas monetárias. Em este último aspecto se estabelece la vinculación entre la gestión patrimonial y la financiera”.

Registra o jurista argentino que o patrimônio do Estado, como matéria administrável e como objeto da gestão patrimonial, apresenta o conjunto de bens susceptíveis de posse estática (coisas móveis e imóveis, alguns direitos patrimoniais e créditos) que o Estado possúi e que podem ser utilizados como instrumento material dos serviços públicos ou mesmo como fonte de rendas aplicáveis a estes mesmos serviços. Exclui os dinheiros porque diz que este ingressa no tesouro para ser aplicado na prestação dos serviços públicos e não para permanecer em poder do ente. Assim, diz que a contabilidade dos bens deve acontecer em um registro patrimonial e a dos dinheiros em um registro financeiro.

Chama a atenção para a diferença do patrimônio privado, quando ao analisálo afirma que o conjunto de bens se vincula ao sujeito como elemento homogêneo por uma consideração jurídica (a universalidade de direito) e por uma consideração econômica (a valoração em dinheiro) enquanto que o patrimônio do Estado como matéria administrável se vincula com a Fazenda homogeneizado por um caráter comum, qual seja, a possessão estática e permanente.

\footnotetext{
${ }^{296}$ ATCHABAIHAN, Adolfo. Régimen jurídico de la gestion y del control em la hacienda pública. $3^{\mathrm{a}}$ Ed. . Buenos Aires: La Ley, 2008. P.511-512
} 
Este pensamento permite que se desenhe a tênue linha que separa o significado da expressão 'Patrimônio Público' daquela outra 'Patrimônio do Estado' e em consequência que se adote 'Fiscalização do Patrimônio Público' para o controle da sociedade sobre tudo que está inserido na primeira expressão e 'Fiscalização Patrimonial da Administração Pública' para os da segunda, ambos respeitando os diversos mecanismos estudados ao longo do trabalho.

Atchabaian ainda refere a necessidade de se elaborar regras para a contabilidade patrimonial, e indica que este aspecto persegue várias finalidades, como: “a) determinar lós bienes del Estado, para permitir su utilización y conservación, física e jurídica; b) regular con normas jurídicas coactivas la gestión de lós bienes de posesión estática; c) delimitar la responsabilidade de los encargados de la administración de esos bienes; d) demonstrar, no ya la solvencia del Estado, pero sí que lós bienes poseídos por él son suficientes para prestar lós servicios públicos”.

Estes elementos, acrescidos dos demais outros vistos, mostram adequadamente aspectos a serem trabalhados na fiscalização patrimonial da administração pública e em nada divergem do ordenamento jurídico brasileiro, visto que apresentam caráter supranacional, diante de sua característica eminentemente voltada para o bem estar social.

Portanto, afirma-se, diante destas derradeiras considerações e ainda daquelas já realizadas, que a fiscalização do patrimônio público é imperativa e nela está inserida a fiscalização patrimonial da administração pública, que, respeitando as respectivas competências dos órgãos fiscalizadores e os limites legalmente fixados, acontece em última ratio em favor da sociedade.

E pelo mesmo motivo, indicando a importância social do tema, o Poder Judiciário admitiu que dano ao patrimônio público é considerado imprescritível, podendo se buscar a qualquer momento o ressarcimento.

Conforme publicação do Diário de Justiça Eletrônico n. 223, de 24 de novembro de 2011, o Supremo Tribunal Federal decidiu, nos autos do Recurso Extraordinário $\mathrm{n}^{\circ}$ 601.707, oriundo de ação do Ministério Público de São Paulo, de 
relatoria do Ministro Dias Tofooli, que não incide prescrição para o ressarcimento do patrimônio público.

Reconheceu a decisão que o então acórdão recorrido (de Recurso Especial, junto ao Superior Tribunal de Justiça) divergiu de entendimento consolidado na Corte no julgamento do MS $\mathrm{n}^{\circ}$ 26.210/DF, de relatoria do Ministro Ricardo Lewandowski, publicado no DJe de 10/10/08, no sentido da imprescritibilidade das ações de ressarcimento de danos ao erário, nos termos do disposto no artigo 37 , parágrafo $5^{\circ}$, da Constituição Federal, no qual se citou lição de José Afonso da Silva:, como segue: “ $A$ prescritibilidade, como forma de perda da exigibilidade de direito, pela inércia de seu titular, é um princípio geral de direito. Não será, pois, de estranhar que ocorram prescrições administrativas sob vários aspectos, que quanto às pretensões de interessados em face da Administração, que quanto ás desta em face de administrados. Assim é especialmente em relação aos ilícitos administrativos. Se a Administração não toma providência à sua apuração e à responsabilização do agente, a sua inércia gera a perda do seu 'ius persequendi' . É o princípio que consta do art. 37, $\S 55^{\circ}$, que dispõe: 'A lei estabelecerá os prazos de prescrição para ilícitos praticados por qualquer agente, servidor ou não, que causem prejuízo ao erário, ressalvada as respectivas ações de ressarcimento'. Vê-se, porém, que já uma ressalva ao princípio. Nem tudo prescreverá. Apenas a apuração e punição do ilícito, não, porém, o direito da Administração ao ressarcimento, à indenização, do prejuízo causado ao erário. É uma ressalva constitucional e, pois, inafastável e, por certo, destoante dos princípios jurídicos, que não socorrem quem fica inerte ('dormientibus non sucurrit ius')'. 297

Finalmente, é de se afirmar que a par de toda a técnica que permeia o estudo, não se pode deixar, jamais, de lado, o lado humanístico que é o pano de fundo para todas as relações estabelecidas no universo concreto e real.

\footnotetext{
297 A decisão ainda menciona outros precedentes como Agravo Regimental em RE no 608.831/SP-AgR, Segunda Turma, Relator o Ministro Eros Grau, DJe de 26/6/10) e Agravo Regimental em RE no 578.428/RSAgR, Segunda Turma, Relator o Ministro Ayres Britto, DJe de 14/11/11, além de decisões monocráticas: RE n 632.512/MG, Relatora a Ministra Cármen Lúcia, DJe de 14/4/11; e AI n 834.949/SP, Relator o Ministro Luiz Fux, DJe de 9/11/11.
} 
Assim, os aspectos de controles mútuos estabelecidos pelo grupo social, a partir daquele de regência no qual cada indivíduo abre mão de parcela de sua liberdade em favor de um ente abstrato criado para administrar as complexas relações sociais, e no qual se inclui o processo de fiscalização patrimonial da administração pública, somente existem porque não encontrada, ainda, a utópica sociedade ideal, na qual a confiança mútua plena não exigiria mecanismos de controles, afinal “...a experiência da vida é um lento aprendizado que nos ensina a sobreviver e a conviver com nosso semelhante, ${ }^{, 298}$.

Neste sentido, me permito encerrar o pensamento com um toque de $\operatorname{arte}^{299}$ :

Si tus manos están dispuestas a dar lo poco que pueden, ábrelas.

Si tus labios sólo se abren para hablar com cariño, jamás los cierres.

Si tu calor es lo único que puedes compartir, eso no es poco.

Si tus valores los cuidas y los compartes, eres muy grande.

Si tu meta es vivir junto a mi amigo, enseñame a vivir contigo.

Isabel Llorente Casado - poetisa espanhola

\footnotetext{
${ }^{298}$ KUJAWSKI, Gilberto de Mello. O sentido da vida. São Paulo: Ed. Gaia. 2010. P.161

299 Citado em artigo de Fernando Altemeyer Jr, professor do Departamento de Ciência da Religião da PUC/SP, in Revista “O Mensageiro de Santo Antonio”. Junho 2010, p.08.
} 


\section{CAPÍTULO 7 - BIBLIOGRAFIA.}

$7.1-$ Livros

AGUIAR, Ubiratan. Controle Externo. Belo Horizonte: Ed. Forum, 2006.

ALEXY, Robert. Teoria dos Direitos Fundamentais. Tradução de Virgílio Afonso da Silva da $5^{\mathrm{a}}$ ed. alemã. São Paulo: Malheiros, 2008.

AlMEIDA, J, Canuto Mendes de. Processo Penal, ação e jurisdição, Revista dos Tribunais, 1975.

ARAÚJO, Edmir Netto de, Responsabilidade do Estado por ato jurisdicional, São Paulo: RT, 1981.

Curso de Direito Administrativo. São Paulo, Saraiva, 2006.

Curso de Direito Administrativo, 5a Ed. São Paulo: Saraiva,

2010.

Administração Indireta Brasileira, Rio de Janeiro: Forense

Universitária, 1997.

ARAÚJO, Florivaldo Dutra de. Motivação e controle do ato administrativo. Belo Horizonte: Del Rey, 1992.

ASCENSÃO, José de Oliveira. Introdução à ciência do direito. Rio de Janeiro: Renovar, 2005.

ATCHABAIHAN, Adolfo. Régimen jurídico de la gestion y del control em la hacienda

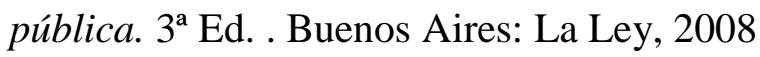

ÁVILA, Humberto Bergmann. Teoria dos Princípios. Da definição à aplicação dos princípios jurídicos. $9^{\mathrm{a} e d . ~ S a ̃ o ~ P a u l o: ~ M a l h e i r o s, ~} 2009$.

AZAMBUJA, Darcy, Teoria Geral do Estado. 4. ed. Porto Alegre: Globo, 1963. 
BALEEIRO, Aliomar. Uma introdução à ciência das finanças. $14^{\mathrm{a}}$ Ed. Rio de Janeiro: Forense, 1992.

BANDEIRA DE MELLO, Celso Antonio. Curso de direito administrativo. 4.ed.. São Paulo: Malheiros, 1993.

BASTOS, Celso Ribeiro. Comentários à Constituição de 1988, 1. ed., Julex, 1989.

Curso de Teoria do Estado e Ciência Política, Saraiva: São

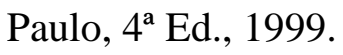

BOBBIO, Norberto. A era dos direitos, Rio de Janeiro: Ed. campus, 1992.

BONAVIDES, Paulo. Do estado liberal ao estado social. $7^{\text {a }}$ ed. São Paulo: Malheiros, 2004.

. Ciência Política, 17ª ed. São Paulo: Malheiros, 2010.

BORINELli, Márcio Luiz; SOUZA, Bruno Carlos de e PIMENTEL, Renê Coppe. Apostila de finanças e contabilidade - Curso de Desenvolvimento Profissional para Executivos. FIA - Fundação Instituto de Administração. 2010.

BUGARIN, Paulo Soares. $O$ princípio constitucional da Economicidade na jurisprudência do Tribunal de Contas da União. Belo Horizonte: Ed. Forum, 2004.

BUZZO ALVES et al. Org. Funções Institucionais do Ministério Público, Saraiva, 2001.

CABRAL NETTO, J. O Ministério Público na Europa Latina. Belo Horizonte, Imprensa Oficial de Minas Gerais, 1974.

CANOTILHO, José Joaquim Gomes. Direito Constitucional. $7^{\mathrm{a}}$ ed. Coimbra: Almedina, 2003.

CANOTILHO, José Joaquim Gomes; MOREIRA, Vital. Fundamentos da Constituição. Coimbra, PT: Coimbra Editora, 1991.

Constituição da República Portuguesa anotada, vol. 1. São

Paulo: Editora Revista dos Tribunais; Coimbra, PT: Coimbra Editora, 2007. 
CASTARDO, Hamilton Fernando. O Tribunal de Contas no ordenamento jurídico brasileiro. Campinas: Millenium, 2007.

CASTILHO, Ricardo. Justiça Social e Distributiva: desafios para concretizar direitos sociais. São Paulo: Saraiva, 2009.

CHAVES, Francisco Eduardo Carrilho. Controle Externo da Gestão Pública. Niterói: Impetus, 2007.

CHECCHINI, Vincenzo Manzini, Trattato di diritto processuale penale italiano. Torino, 1924.

COELHO, Paulo Magalhães da Costa. Controle Jurisdicional da Administração Pública. São Paulo: Saraiva, 2002.

COHEN, Bruce. Sociologia Geral. São Paulo: McGraw-Hill do Brasil, 1980.

CONTI, José Maurício (org). Federalismo fiscal. São Paulo, Manole, 2003.

A autonomia financeira do Poder Judiciário. São Paulo. MP, 2006.

Direito Financeiro na Constituição de 1988. São Paulo: Oliveira

Mendes, 1998.

COUTINHO, José Roberto de Andrade. Gestão Patrimonial na Administração Pública. Rio de Janeiro: Lumen Juris, 2004.

CRETELLA JÚNIOR, José. Anulação do ato administrativo por desvio de poder. Rio de Janeiro: Forense, 1978.

O Estado e a obrigação de indenizar. São Paulo: Saraiva, 1980.

Tratado do domínio público, Rio de Janeiro, Forense, 1984.

Do impeachment no direito brasileiro, São Paulo: RT, 1992.

Manual de Direito Administrativo. Rio de Janeiro, Forense, 2000.

Curso de Direito Administrativo. Rio de Janeiro, Forense, 2002. 
DA SILVA, José Afonso. Curso de Direito Constitucional Positivo. $30^{\mathrm{a}}$ ed. revista e atualizada. São Paulo, Malheiros, 2008.

DALlARI, Adilson de Abreu. Administração Pública no Estado de Direito. Revista Trimestral de Direito Público, 5/40.

Regime constitucional dos servidores públicos, São Paulo: RT.

1990.

DAVID, René. Os grandes sistemas do direito contemporâneo. Hermínio A. Carvalho (trad.). $4^{\text {a }}$.ed. São Paulo: RT, 1999.

DEBBASCH, Charles. Institutions et droit administratifs, Paris: PUF, 1956.

DE PLÁCIDO E SILVA. Vocabulário Jurídico, 27ª ed. Rio de Janeiro: Forense, 2006.

DI PIETRO, Maria Sylvia Zanella, Direito Administrativo.13 ${ }^{\text {a }}$ ed. São Paulo: Atlas, 2001.

DROMI, Roberto. Derecho administrativo. 10. Ed. Buenos Aires: Ciudad Argentina, 2004.

ESMEIN. Histoire de la procédure criminelle em France et spécialement de la procédure inquisitoire depuis le XIII siècle jusqu'à nos jours. Paris, 1882.

FARIA, Ernesto - org. -Dicionário Escolar Latino-Português, $3^{\mathrm{a}}$. ed.Rio de Janeiro: MEC, 1962.

FERNANDES, Jorge Ulisses Jacoby. Tribunais de Contas do Brasil: jurisdição e competência. $1^{\mathrm{a} E d}$. $2^{\mathrm{a}}$ tiragem. Belo Horizonte: Ed. Forum, 2003.

FERREIRA, Aurélio Buarque de Holanda; Ed, Nova Fronteira, RJ, 1986.

FIGUEIREDO, Lucia Vale. Curso de Direito Administrativo, São Paulo: Malheiros, 1994.

FRANÇA, Phillip Gil. O controle da administração pública. 2a ed. São Paulo, RT. 2010.

FRANÇA, Rubens Limongi (Org.). Enciclopédia Saraiva de Direito. São Paulo: Saraiva, 1977. 
FREITAS, Juarez. O controle dos atos administrativos e os princípios fundamentais. $4^{\mathrm{a}}$ ed. São Paulo: Malheiros, 2009.

GASPARINI, Diógenes. Direito Administrativo, $8^{\text {a }}$ Ed. São Paulo: Saraiva, 2003.

GOMES, Emerson Cesar da Silva. Responsabilidade Financeira. Porto Alegre: Nubia Fabris Editora. 2012.

GRAZZIOLI, Airton e RAFAEL, José Edson. Fundações Privadas. São Paulo: Atlas. 2009.

GUALAZZI, Eduardo Botelho Lobo. Regime jurídico dos Tribunais de Contas. São Paulo: RT, 1992.

GUERRA, Evandro Martins. Os controles externo e interno da Administração Publica. Belo Horizonte, ed. Forum. 2005.

HÉLIE, Faustin, Traité de l'instruction criminelle ou théorie du Code d'instruction criminelle. Paris, $2^{\mathrm{a}}$ ed. 1866.

HOFFE Otfried. Justiça Política. São Paulo: Martins Fontes, 2001.

IUDÍCIBUS, Sérgio et al. Contabilidade intermediária.São Paulo: Atlas, 1981.

IUDÍCIBUS, Sérgio de, Teoria da contabilidade, 7 ed. São Paulo: Atlas, 2004.

JUNQUEIRA FILHO, Manoel Otaviano. Ministério Público, Constituição e Processo. São Paulo: Ed. Franciscana, 1971.

KELSEN, Hans. Teoria general Del derecho y Del Estado. 2a Ed., México, Imprenta Universitaria, 1958, trad. De Eduardo García-Maynez.

KOHAMA, H. Contabilidade Pública: teoria e prática. 10ª Ed. São Paulo, Atlas, 2006.

KUJAWSKI, Gilberto de Mello. O Sentido da Vida. São Paulo: Ed. Gaia. 2010.

LA PIERRE, Jean-William. Le pouvoir politique, Paris, PUF, Collection Que saisje? 1953.

LEMBO, Cláudio. A pessoa: seus direitos. $1^{\text {a }}$ Ed. Barueri - SP. Manole, 2007. 
LESBAUPIN, Ivo. Poder Local e Exclusão Social: A experiência das prefeituras democráticas no Brasil. 2a . ed. Petrópolis, RJ: Vozes, 2001.

LOEWENSTEIN, Carl. Teoria de La Constituicion. Biblioteca de Ciência Política. Coleccion Demos. Barcelona: Ariel, $2^{\mathrm{a}}$ ed. 1979.

LOPES, Miguel Maria de Serpa. Curso de Direito Civil. Rio de Janeiro: Freitas Bastos, 1961.

LYRA, Roberto, Teoria e prática da promotoria pública, Rio de Janeiro, Jacintho, 1937.

MARQUES NETO, Floriano de Azevedo. Bens Públicos - Função Social e Exploração Econômica. O Regime Jurídico das Utilidades Públicas. Minas Gerais: Ed. Forum. 2009.

MARTINS JUNIOR, Wallace Paiva, Probidade Administrativa. São Paulo: Saraiva, 2001.

MARTINS, Fernando Rodrigues, Controle do Patrimônio Público. São Paulo: RT, $3^{\mathrm{a}}$ Ed, 2009.

MAYER, Otto, Derecho administrativo alemán, Trad. De H. Heredia e E. Krotoschin. Buenos Aires, Depalma, 1949 e 1951.

MAZZILI, Hugo Nigro. A defesa dos interesses difusos em juízo, São Paulo: Saraiva, 19a ed. 2006. A defesa dos interesses difusos em juízo. São Paulo: Saraiva, 22a ed. 2009. Introdução ao Ministério Público. São Paulo: Saraiva. $2^{\mathrm{a} e d .}$ 1.998 .

MEDAUAR, Odete. Direito Administrativo Moderno. 10a ed. São Paulo: Editora Revista dos Tribunais, 2006.

MEIRELLES, Hely Lopes. Direito administrativo Brasileiro, RT, 1977. Direito Administrativo Brasileiro. $21^{\circ}$. Ed.Sao Paulo: Malheiros, 1996. 
Direito Administrativo Brasileiro, $24^{\mathrm{a}}$ edição, São Paulo:

Malheiros, 1999.

Direito Administrativo Brasileiro. $26^{\mathrm{a}}$ Ed. atualizada por Eurico de Andrade Azevedo, Délcio Balestero Aleixo e José Emmanuel Burle Filho. São Paulo: Malheiros, 2001.

Direito Administrativo Brasileiro, $34^{\mathrm{a}}$ Ed. São Paulo:

Melhoramentos, 2008.

MELlo, Celso Antonio Bandeira de. Prestação de serviços públicos e administração indireta. São Paulo: RT. 1975

Curso de Direito Administrativo. $4^{\mathrm{a}}$ ed. São Paulo: Malheiros,

1993.

Curso de Direito Administrativo. $15^{\mathrm{a}}$. ed. São Paulo: Malheiros,

2003.

Curso de Direito Administrativo. 24 ed. São Paulo: Malheiros,

2007.

Curso de Direito Administrativo. $26^{\mathrm{a}}$ ed. São Paulo: Malheiros,

2009.

MILESKI, Helio Saul. O Controle da Gestão Pública. São Paulo: RT. 2003.

MORAES, Alexandre. Direito Constitucional. São Paulo: Atlas, 1999.

NASCIMENTO, Carlos Valder do, et alii. Comentários à Lei de Responsabilidade Fiscal. Organizadores: MARTINS, Ives Gandra da Silva e NASCIMENTO, Carlos Valder do. São Paulo: Saraiva, 2001.

MOTA, Francisco Glauber Lima. Contabilidade aplicada à Administração Pública. $6^{\mathrm{a}}$ ed. Brasilia: Vestcon, 2003. 
NERY, Nelson Jr; NERY, Rosa Maria de Andrade. Código de Processo Civil e legislação processual civil extravagante-Comentado, ed. RT, $1^{\mathrm{a}}$ ed., nota 1 ao art. 17 da Lei Federal $8.429 / 92$.

NUNES Jr. Vidal Serrano; ARAUJO. Luiz Alberto David. Curso de Direito Constitucional. $3^{\text {a }}$. ed.São Paulo: Saraiva, 1999.

OLIVEIRA, Régis Fernandes. O Juiz na Sociedade Moderna. São Paulo: FTD, 1998.

Curso de Direito Financeiro. São Paulo: Revista dos Tribunais, 2006.

OSÓRIO, Fábio Medina. Teoria da Improbidade Administrativa. São Paulo: RT, 2007.

PASCOAL, Valdecir. Direito Financeiro e Controle Externo. Rio de Janeiro: Elsevier, 2006.

PAZZAGLINI FILHO, Marino; ROSA, Márcio Fernandes Elias e FAZZIO JR, Waldo. Improbidade Administrativa. 4ª ed. São Paulo: Atlas, 1999.

PIERANGELli, José Henrique. Processo Penal; evolução histórica. São Paulo: Jalovi, 1983.

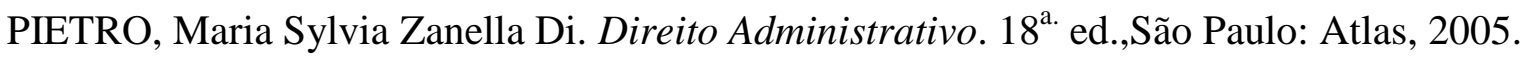

PISCITELLI, Roberto Bocaccio; TIMBÓ, Maria Zulene Farias. Contabilidade Pública Uma abordagem da Administração Financeira Pública. 10ª Ed. São Paulo: Atlas, 2009.

RASSAT, Michèle-Laure. Le Ministère Public entre son passé et son avenir. Paris, Librairie Général de Droit et de Jurisprudence, 1967.

REZENDE FILHO, Gabriel de. Curso de direito processual civil. São Paulo: Saraiva, 1957.

REZENDE FILHO, Gabriel. Curso de direito processual civil, São Paulo: Saraiva, 1957.

RITT, Eduardo. O Ministério Público como instrumento de democracia e garantia constitucional. Porto Alegre: Livraria do Advogado Editora. 2002. 
RODRIGUES, Silvio. Direito Civil. Vol1. Parte geral, 32a ed. São Paulo. Saraiva, 2002.

SALANDRA, Antonio. Lezioni di diritto amministrativo. Roma: Associazione Universitaria Romana, 1909.

SANTOS, Moacyr Amaral. Primeiras linhas de direito processual civil, São Paulo: Saraiva, 1978.

SARLET, Ingo Wolfgang. A eficácia dos direitos fundamentais. $10^{\mathrm{a}}$ Ed. Porto Alegre: Livraria do Advogado, 2009.

SCAFF, Fernando Facury. Constitucionalismo, Tributação e Direitos Humanos. São Paulo: Renovar, 2006.

SERRA, Truyol y. História da filosofia do Direito e do Estado. Lousa, Instituto de Novas Profissões, 1990.

SERRANO, Pedro Estevam Alves Pinto. Região Metropolitana e seu regime constitucional. São Paulo: Verbatim, 2009.

SICHES, Luis Recasens. Tratado General de Filosofia Del Derecho. México: Porrúa, 1965.

SILVA, De Plácido e. Vocabulário jurídico. $27^{\mathrm{a}}$ ed. Rio de Janeiro: Forense, 2006.

SILVA, José Afonso. Curso de Direito Constitucional Positivo, São Paulo: Malheiros, $26^{\mathrm{a} e d .} 2006$.

SILVA, Octacílio Paula. Ministério Público. São Paulo: Sugestões Literárias, 1981.

SOUZA JÚNIOR, José Geraldo de. (org). Sociedade democrática, direito público e controle externo. Brasilia: Tribunal de Contas da União, 2006.

TÁCITO, Caio. Controle Judicial da Administração Pública. Revista de Direito Público, n $91,1989$. 
TORNAGHI, Hélio. Compêndio de processo penal. Rio de Janeiro: Konfino, 1967.

TORRES, Ricardo Lobo, Curso de Direito Financeiro e Tributário. Rio de Janeiro: Renovar, 2006.

TOURINHO FILHO, Fernando da Costa. Processo Penal. São Paulo: Saraiva. 1982.

TRUJILLO, Élcio. Responsabilidade do Estado por ato lícito. São Paulo: Editora de Direito, 1996.

VELLANI, Mario. Il pubblico ministero nel processo, Bologna, 1965.

VENOSA, Silvio de Salvo. Direito Civil. São Paulo: Atlas, 2006.

7.2 - Artigos e Textos.

ALTEMEYER JR, Fernando. Revista O Mensageiro de Santo Antonio. Junho 2010.

ANDRETA, Dalberto. Aspectos Legais e Controles nas Subvenções Sociais ao Terceiro Setor. Revista de Negócios/Business Review - ISSN, 1980/2080 - nº 09, Março 2010.

ASSONI FILHO, Sérgio. Artigo "Direito Administrativo Comparado: Unidade $e$ Duplicidade de Jurisdição”. Revista IOB de Direito Administrativo. Ano I, n.2. Fev/2006.

BLAMONT, Émile. Lês conditions du controle parlamentaire. Revue de Droit Public et de La Science Politique, abr-jun 1950.

BRAGA, Carlos Eduardo Faraco, artigo "A fiscalização financeira e o Tribunal de Contas".

CARDUCCI, Piero; SANTORUFO, Maria; ZINNO, Fulvia. La riforma dell'Amministrazione Pubblica e nuove formedi controllo nella Prefetture - Uffici Territoriali Del Governo. Instrumenta, n.22, a, VIII, 2004. 
CARTES, Juan Eduardo Toledo. El control interno de La administracion: modernización de lós sistemas como uma emergencia. VIII Congresso Internacional de CLAD sobre La reforma Del Estado y de la Administracion Pública, Panamá, 28-31 oct.2003.

CITADINI, Antonio Roque. Fiscalização da Administração Pública. Palestra proferida na Escola Paulista da Magistratura em 23 de fevereiro de 2005.

CONTI, José Mauricio e CARVALHO, André Castro. $O$ controle interno na Administração Pública brasileira: Qualidade do gasto público e responsabilidade fiscal. Revista de Direito Público, ano VIII, nº 37, jan-fev.2011.

DEROZA, Maria de Lourdes. Controles Internos: aspectos gerais da avaliação dos controles de gastos precedidos de licitação. Monografia - TCU, Brasilia, 2004.

DI PIETRO, Maria Sylvia Zanella, "O direito administrativo brasileiro sob influência dos sistemas de base romanística e da common law”. Revista Brasileira de Direito Público. Belo Horizonte: Ed. Fórum. n.16. jan/mar 2007.

FAJARDO, Cláudio Marcelo Spalla. Súmula STF $n^{\circ}$ 346: Uma nova abordagem sobre a competência do TCU para apreciar a constitucionalidade de leis e de atos normativos do Poder Público. Revista do TCU. Ano 40. № 111 - Janeiro/Abril. 2008.

FURLAN, Melissa. Artigo “Os sistemas jurídicos, suas diferenças e aproximações” in Revista de Direito Privado, RT, Ano 8. n.31, jul-set/2007

GARCIA, Emerson. O Ministério Público e a Defesa do Princípio da Impessoalidade. Revista dos Tribunais, vol. 799, maio 2002.

. A moralidade administrativa e sua densificação. Revista de Direito Constitucional e Internacional. Ano 11, no 43, abr/jun 2003. 
LIMA, Raimundo Márcio Ribeiro. Premissas principiológicas e garantísticas indispensáveis a uma regular atuação da administração pública e o silêncio administrativo. Revista a Advocacia Geral da União, Ano X, no 28. Brasilia-DF, abr./jun. 2011.

MEDAUAR, Odete, Controles internos da Administração Pública. Boletim de Direito Administrativo, $\mathrm{n}^{\circ}$ 06, p.366, 1992.

MORAES, Alexandre de. Controle externo do Poder Judiciário. Revista de Informação Legislativa, Brasilia, no. 140,out/dez1998.

RAMOS, Elival da Silva, Aspectos gerais do patrimônio imobiliário do Poder Público. In Cadernos FUNDAP, nº 17, São Paulo, 1989.

REVISTA JURÍDICA. Novos Direitos e Proteção da Cidadania. Escola Superior do Ministério Público do Estado de São Paulo: Imprensa Oficial do Estado de São Paulo, 2009.

SCAFF, Fernando Facury, Sentenças Aditivas, Direitos Sociais e Reserva do Possível. Revista Dialética de Direito Processual, nº 51, 2007

SILVA, Artur Adolfo Cotias e. Tribunal de Contas da União na histórica do Brasil. Evolução histórica, política e administrativa (1890-1998). in Brasil. Tribunal de Contas da União. Prêmio Serzedello Corrêa 1998 - Monografias Vencedoras - $1^{\circ}$ lugar. Brasilia: TCU, Instituo Serzedello Corrêa, 1999.

SPINELLI, Marioa Vinicius Claussen. Brasil e Estados Unidos: O sistema de controle interno do poder executivo federal em perspectiva comparada. Revista da CGU, $6^{\mathrm{a}}$ ed. set.2009.

TEIXEIRA, Júlio César Azevedo. Evidenciação das renúncias de receitas tributárias federais pela Contabilidade Pública: importância e dificuldades. Brasília, DF. 2006 
TORRES, Ricardo Lobo, A legitimidade tributária e o Tribunal de Contas, Revista de Direito Administrativo 194/31-45, Rio de Janeiro, out-dez. 1993.

TCU - Revista do Tribunal de Contas da União - abr/jun 2003.

7.3 - Internet

7.3.1 - Sites Nacionais

Controladoria Geral da União -

http://www.cgu.gov.br/ConselhoTransparencia/Competencias.asp

Fundação Getúlio Vargas -

http://www.fgv.br/fgvprojetos/economicidade/arq/Aspectos\%20Gerais\%20FGV\%20Econo micidade\%203mai2005.pdf

www.gv.br/biblioteca/pe/sp000503359.pdf

http://cpdoc.fgv.br/producao/dossies/FatosImagens/PetrobrasAutoSuficiencia

Governo do Brasil -

http://www.brasil.gov.br/sobre/o-brasil/estrutura/agencias-reguladoras

http://www.planalto.gov.br/leg.asp

http://www.rededecontrole.gov.br/portal/page/portal/rededecontrole/acordos

http://www.rededecontrole.gov.br/portal/page/portal/rededecontrole/sobre

http://www.tesouro.fazenda.gov.br/contabilidade_governamental/download/RES_CFC112 92008_NBC_T162_Patrimonio\%20_Sistemas_Contabeis.pdf 
Governo do Estado de São Paulo -

http://www.sancoes.sp.gov.br/

Ministério Público do Estado de São Paulo -

www.mp.sp.gov.br/conselho

www.mp.sp.gov.br/portal/page/porta/noticias

http://www.mp.sp.gov.br/portal/page/portal/Controladoria_Geral

www.mp.sp.gov.br

http://www.pjc.sp.gov.br/noticiaspub1.asp?id=125

Município de Campinas -

www.campinas.sp.gov.br

Município de São Paulo -

http://www.capital.sp.gov.br/portalpmsp/homec.jsp

Superior Tribunal de Justiça -

www.stj.jus.br.

http://www.sti.jus.br/SCON/jurisprudencia/doc.jsp?livre=improbidade+e+patrim\%F4nio+ $\mathrm{p} \%$ FAblico $\& \& \mathrm{~b}=\mathrm{ACOR} \& \mathrm{p}=$ true $\& \mathrm{t}=\& \mathrm{l}=10 \& \mathrm{i}=6 \#$

http://www.stj.gov.br/SCON/jurisprudencia/toc.jsp. 
Supremo Tribunal Federal -

www.stf.jus.br

http://www.stf.jus.br/portal/processo/verProcessoAndamento.asp?incidente=1829732

http://www.stf.jus.br/portal/jurisprudencia/visualizarEmenta.asp?s1=000105522\&base=bas $\underline{\text { eAcordaos }}$

http://www.stf.jus.br/portal/jurisprudencia/visualizarEmenta.asp?s1=000110288\&base=bas $\underline{\text { eAcordaos }}$

http://www.stf.jus.br/portal/jurisprudencia/visualizarEmenta.asp?s1=000185964\&base=bas $\underline{\text { eAcordaos }}$

http://www.stf.jus.br/portal/jurisprudencia/visualizarEmenta.asp?s1=000169187\&base=bas $\underline{\text { eAcordaos }}$

http://www.stf.jus.br/portal/constituicao/constituicao.asp

Tribunal de Contas do Estado de São Paulo -

http://www.tce.sp.gov.br

Tribunal de Contas da União -

http://www.tcu.gov.br

http://contas.tcu.gov.br/pt/MostraDocumento?qn=5

http://portal2.tcu.gov.br/portal/pls/portal/docs/2055712.PDF 
Outros -

$\underline{\text { www.citadini.com.br }}$

http://www.cpcon.eng.br/gestao-patrimonial/gestao/tipos-de-bens-gestao-patrimonio/

http://farolpolitico.blogspot.com.br/2007/10/legitimidade_12.html.

http://www.normaslegais.com.br/legislacao/resolucaocfc1143_2008.htm

www.r2learning.com.br/site/artigos/artigo_default.asp?ID=419

http://www.saudebucalcoletiva.unb.br/ensino/introducao_a_ciencia_politica/8_3_Legitimi dade.pdf

http://www.sindspem-

ma.com.br/arquivos/file/comunicados/Decisao_do_TCU_sobre_Aposentadoria_de_Policia 1.pdf.

http://www.unifin.edu.br/Content/arquivos/20111006204404.pdf

7.3.2 - Sites Extrangeiros.

Intosai - International Organization of Supreme Audit Institutions www.intosai.org

Organization for Economic Co-operation and Development http://www.oecd.org 
7.4 - Acórdãos e Decisões

Brasil, Supremo Tribunal Federal:

.Ação Direta de Inconstitucionalidade nº88 MC, (julgado em 26/03/1992)

.Ação Direta de Inconstitucionalidade n ${ }^{\circ} 1.717$

.Ação Direta de Inconstitucionalidade no 3944 (julgado em 05/08/2010)

.Ação Direta de Inconstitucionalidade $\mathrm{n}^{\circ}$ 2.238/DF (decisão parcial de plenário de 09.08.2007)

.RE 206889 (julgado em 25/03/1997)

.RE 190.985 (julgamento em 14/02/1996)

.Reclamação nº 601 (in Revista de Direito Administrativo 206/267)

.Reclamação n554-2/MG. (Diário da Justiça, seção I, 26.11.97, p. 61.738)

.RMS 25.943 (julgamento em 24/11/2010)

.Suspensão de Segurança no 3.902-4 (Publicação em 08/07/2009)

Brasil, Superior Tribunal de Justiça:

- STJ - REsp 1151884/SC, (julgado em 15/05/2012) 
Brasil, Tribunal Federal de Recursos, $2^{\mathrm{a}}$ Região:

- TRF2 - Apelação Cível: AC 200202010125983. RJ 2002.02.01.012598-3

Brasil, Tribunal de Contas da União:

- TCU, Acórdão nº 279/00. Plenário: AC-0279-43/00-p, in DOU de 14.11.00

- TCU. Acórdão no 128/00. Plenário: AC-0128-32/99-p - DOU de 05.08.99

\section{5 - Legislação}

- Legislação Federal do Brasil.

Constituição Federal do Brasil de 1967

Constituição Federal do Brasil de 1988

Lei $n^{\circ}$ 657/1831 (Aprovando a criação do Tribunal do Tesouro Público Nacional em substituição ao Erário)

Decreto n ${ }^{\circ 666-A / 1890 ~(C r i a c ̧ a ̃ o ~ d o ~ T r i b u n a l ~ d e ~ C o n t a s ~ d a ~ U n i a ̃ o) ~}$

Lei n 3071/1916 (antigo Código Civil)

Decreto-Lei no 2.848/1940 (Código Penal - reformado pela Lei $n^{\circ} 7.209$ de 11 de julho de 1984)

Lei ${ }^{\circ} 1079 / 1950$ (Define os crimes de responsabilidade e regula o respectivo processo de julgamento) 
Lei n. ${ }^{\circ} 4.215 / 1963$ (Estatuto da OAB revogado)

Lei n ${ }^{\circ}$ 4.320/1964 (Estatui Normas Gerais de Direito Financeiro para elaboração e contrôle dos orçamentos e balanços da União, dos Estados, dos Municípios e do Distrito Federal)

Lei Federal nº 4.717/1965 (Ação popular)

Decreto-lei 200/1967 (Organização da Administração Federal e diretrizes para a Reforma Administrativa)

Decreto-Lei nº 201/1967 (Dispõe sobre a responsabilidade dos Prefeitos e Vereadores)

Emenda Constitucional n ${ }^{\circ} 1 / 1969$

Decreto-lei nº 900/1969 (Realiza alterações do Decreto Lei nº 200/1967)

Lei no 5.869/1973 (Código de Processo Civil)

Lei Federal n 6.223/1975 (Dispõe sobre a fiscalização financeira e orçamentária da União, pelo Congresso Nacional)

Lei Federal $n^{\circ}$ 6.525/1978 (Submete à fiscalização financeira do Tribunal de Contas as entidades com personalidade jurídica de direito privado, de cujo capital a União, o Estado, o Distrito Federal, o Município ou qualquer entidade da respectiva administração indireta seja detentor da totalidade ou da maioria das ações ordinárias)

Lei Complementar nº 35/1979 (LOMAN - Lei Orgânica da Magistratura)

Lei $n^{\circ}$ 6.799/1980 (Dispõe sobre causa de especial aumento de pena, quanto aos crimes contra a Administração Pública, praticados por ocupantes de cargos em comissão da administração direta e indireta e regula a forma de seu procedimento)

Lei n. ${ }^{\circ}$ 6.830/1980 (Lei de Execução Fiscal e disposição sobre a cobrança judicial da Dívida Ativa da Fazenda Pública) 
Lei $n^{\circ}$ 6938/1981 (Dispõe sobre a Política Nacional do Meio Ambiente, seus fins e mecanismos de formulação e aplicação)

Decreto-lei no 2.299/1986 (Incluiu as fundações federais entre os órgãos da administração indireta)

Decreto $n^{\circ}$ 93.872/1986 (Dispõe sobre a unificação dos recursos de caixa do Tesouro Nacional)

Lei $\mathrm{n}^{\mathrm{o}}$ 7.596/1987 (Alterações ao DL 200/67)

Lei Complementar nº 64/1990 (Estabelece casos de inelegibilidade)

Lei $n^{\circ}$ 8.078/1990 (Código do Consumidor)

Lei $\mathrm{n}^{\circ}$ 8.112/1990 (Regime Jurídico dos Servidores Públicos Civis da União, das Autarquias e das Fundações Públicas Federais.)

Lei $\mathrm{n}^{\circ} 8.137 / 1990$ (Crimes contra a ordem tributária)

Lei $\mathrm{n}^{\mathrm{o}}$ 8.429/1992 (Lei de Improbidade Administrativa e respectiva previsão do procedimento administrativo e do processo judicial)

Lei $n^{\circ}$ 8.443/1992 (Lei Orgânica do Tribunal de Contas da União).

Lei nº 8.625/1993 (Lei Orgânica Nacional do Ministério Público - LONMP)

Lei Complementar n 75/1993 (Lei Orgânica dos Ministérios Públicos da União - Federal, do Trabalho, Militar e do Distrito Federal e Territórios)

]Lei no 8.666/1993 (Lei das Licitações)

Lei Complementar nº 73/1993 (Lei Orgânica da Advocacia-Geral da União) 
Lei n. ${ }^{\circ}$ 8.906/1994 (Estatuto da Advocacia e da Ordem dos Advogados do Brasil - OAB)

Decreto $\mathrm{n}^{\circ}$ 1.171/1994 (Código de Ética Profissional do Servidor Público Civil do Poder Executivo Federal)

Lei ${ }^{0}$ 9.028/1995 (Exercício das atribuições institucionais da Advocacia-Geral da União, em caráter emergencial e provisório)

Lei 9.478/1997 (Dispõe sobre a política energética nacional, as atividades relativas ao monopólio do petróleo e institui o Conselho Nacional de Política Energética e a Agência Nacional do Petróleo)

Lei no 9.503/1997 - (Código de Trânsito Brasileiro)

Lei $n^{\circ}$ 9.504/1997 (Legislação eleitoral)

Lei no 9.532/1997 (Alteração de legislação tributária)

Decreto $n^{\circ}$ 2.271/1997 (Dispõe sobre a contratação de serviços pela Administração Pública Federal direta, autárquica e fundacional)

Lei $n^{\text {o }}$ 9.637/1998 (Qualificação de entidades como organizações sociais, criação do Programa Nacional de Publicização, extinção dos órgãos e entidades e absorção de suas atividades por organizações sociais)

Lei no 9.649/1998 (Organização da Presidência da Republica e dos Ministérios)

Lei $n^{\text {o }}$ 9.702/1998 (Dispõe sobre critérios especiais para alienação de imóveis de propriedade do Instituto Nacional do Seguro Social - INSS)

Lei Federal no 9.790/1999 (Qualificação de pessoas jurídicas de direito privado, sem fins lucrativos, como Organizações da Sociedade Civil de Interesse Público. Institui e disciplina o Termo de Parceria) 
Decreto Federal $n^{\circ} 3.100 / 1999$ (Regulamenta a Lei $n^{\circ}$ 9.790, de 23 de março de 1999)

Lei nº 9868/1999 (Apresentação de Ação Direta de Inconstitucionalidade perante o STF)

Lei Complementar no 101/2000 (Lei de Responsabilidade Fiscal)

Lei n ${ }^{\circ}$ 9.983/2000 (Alteração do Código Penal acrescendo delitos tributários)

Lei $\mathrm{n}^{\mathrm{o}}$ 10.028/2000 (Altera o Código Penal acrescendo crimes contra as Finanças Públicas).

Lei $n^{\circ} 10.180 / 2001$ (Organiza e disciplina os Sistemas de Planejamento e de Orçamento Federal, de Administração Financeira Federal, de Contabilidade Federal e de Controle Interno do Poder Executivo Federal)

Lei Complementar 105/2001 (Dispõe sobre o sigilo das operações de instituições financeiras)

Lei $\mathrm{n}^{\circ}$ 10.336/2001 (Institui a Cide-Combustíveis - Contribuição de Intervenção no Domínio Econômico incidente sobre a importação e a comercialização de petróleo e seus derivados, gás natural e seus derivados, e álcool etílico combustível)

Lei $n^{\text {o }}$ 10.406/2002 (Novo Código Civil)

Lei n. 10.683/2002 (dispõe sobre a organização da Presidência da República e dos Ministérios)

Lei n ${ }^{\circ}$ 10.683/2003 (Controladoria-Geral da União - CGU)

Decreto $n^{\circ}$ 5.820/2006 (Dispõe sobre a implantação do SBTVD-T, estabelece diretrizes para a transição do sistema de transmissão analógica para o sistema de transmissão digital do serviço de radiodifusão de sons e imagens e do serviço de retransmissão de televisão) 
Decreto n ${ }^{0}$ 6.021/2007 (Cria a “Comissão Interministerial de Governança Corporativa e de Administração de Participações Societárias da União" - CGPAR)

Decreto Federal $n^{\circ}$ 6.170/2007 (Estabelece normas relativas às transferências de recursos da União mediante convênios e contratos de repasse)

Lei Federal n 11.494, de 2007 (FUNDEB - Fundo de Manutenção e Desenvolvimento da Educação Básica e de Valorização dos Profissionais da Educação)

Lei $n^{\circ}$ 12.016/2009 (Mandado de Segurança)

Lei $\mathrm{n}^{\circ}$ 12.351/2010 (Dispõe sobre a exploração e a produção de petróleo, de gás natural e de outros hidrocarbonetos fluidos, sob o regime de partilha de produção, em áreas do présal e em áreas estratégicas; cria o Fundo Social - FS e dispõe sobre sua estrutura e fontes de recursos; altera dispositivos da Lei n⿳⺈ 9.478, de 6 de agosto de 1997)

Resolução do Conselho Federal de Contabilidade n 1.329/2011 (Normas Brasileiras de Contabilidade atualizando a Resolução CFC nº 751/93)

Lei $\mathrm{n}^{\circ}$ 12.708/2012 (Lei de Diretrizes Orçamentárias - LDO - Dispõe sobre as diretrizes para a elaboração e execução da Lei Orçamentária de 2013)

Lei Orçamentária de 2013

- Legislação Estadual

São Paulo:

Lei Complementar Estadual no 709/1993 (Lei Orgânica do Tribunal de Contas do Estado de São Paulo)

Lei Complementar Estadual nº 734/1993 (Lei Orgânica do Ministério Público do Estado de São Paulo - LOMPSP) 
Súmulas:

Supremo Tribunal Federal

$\mathrm{n}^{\circ} 279$

$n^{\circ} 346$

$\mathrm{n}^{\circ} 347$

$n^{\circ} 473$

$n^{\circ} 653$

Superior Tribunal de Justiça

$\mathrm{n}^{\mathrm{o}} 2$

Tribunal de Contas da União

$\mathrm{n}^{\circ} 103$

$\mathrm{n}^{\circ} 180$

Conselho Superior do Ministério Público de São Paulo

n 33

$n^{\circ} 34$ 